\title{
AFTER WATTEAU: \\ NICOLAS LANCRET AND THE \\ CREATION OF THE HUNT LUNCHEON
}

\author{
A Dissertation \\ presented to \\ the Faculty of the Graduate School \\ at the University of Missouri-Columbia \\ In Partial Fulfillment \\ of the Requirements for the Degree \\ Doctor of Philosophy \\ by \\ SARAH SYLVESTER WILLIAMS \\ Dr. Michael Yonan, Dissertation Supervisor \\ JULY 2018
}


(C) Copyright by Sarah Sylvester Williams 2018

All Rights Reserved 
The undersigned, appointed by the dean of the Graduate School, have examined the dissertation entitled

\section{AFTER WATTEAU: NICOLAS LANCRET \\ AND THE CREATION OF THE HUNT LUNCHEON}

presented by Sarah Sylvester Williams,

a candidate for the degree of doctor of philosophy

and hereby certify that, in their opinion, it is worthy of acceptance.

Professor Michael Yonan

Professor James van Dyke

Professor Anne Stanton

Professor Ilyana Karthas 


\section{Dedication Page}

To my family, for their support.

And especially my husband, without whom this would not have been possible. 


\section{ACKNOWLEDGEMENTS}

I would first like to thank my advisor Dr. Michael Yonan who has generously read this dissertation in its many iterations and provided thoughtful feedback. Thanks also goes to my dissertation committee for their time and helpful comments. Additionally, I must recognize Dr. Rochelle Ziskin who first introduced me to the eighteenth century during my time as a master's student at the University of Missouri - Kansas City. This dissertation is indebted to the research accomplished under Dr. Ziskin. The Department of Art History and Archaeology at the University of Missouri - Columbia provided generous support throughout my doctoral studies. The Edzard Baumann Memorial Travel Award from the department supported my research in France and England. I am also grateful for the help of Rachel Jacobs, Assistant Curator and Image Library at Waddesdon Manor, who kindly let me view their paintings by Lancret close-up; Ceri Brough, Archive Assistant, at the National Gallery's Research Centre, who helped with archival research; Madame Dominique Sauvegrain at the Musée d'Angers for allowing me to view the museum's entire dossier on Lancret; Madame Emmanuelle Delapierre at the Musée de Beaux-Arts de Caen for confirming the reattribution of a painting in their collection to an artist other than Lancret; and Léa Ferrez-Le Guet, Assistant Library Specialist at the Château de Chantilly, for her help with their archive materials. 


\section{Table of Contents}

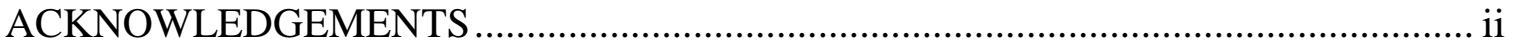

LIST OF ILLUSTRATIONS ......................................................................... iv

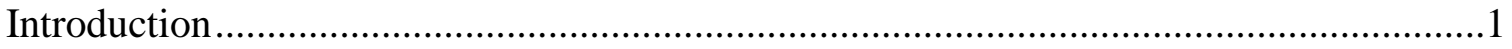

Chapter One - Watteau's Influence on Lancret's Early Works.....................................22

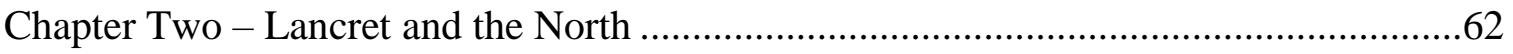

Chapter Three - Lancret's Iconography of Hot Beverages .......................................107

Chapter Four - The Hunt Luncheons ............................................................... 142

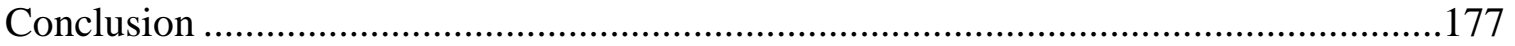

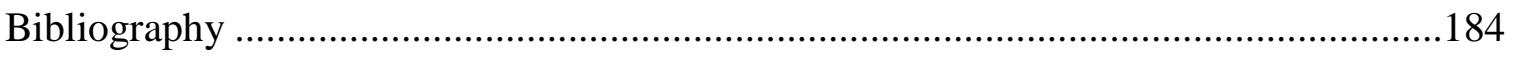

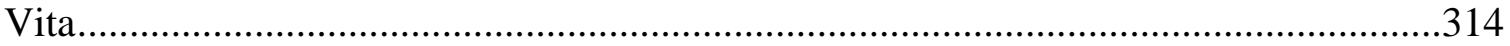




\section{LIST OF ILLUSTRATIONS}

Figure

Page

Figure 1: Antoine Watteau, Pélerinage à l'île de Cythère, 1717. Oil on canvas, 129 x 194 cm, Musée du Louvre, Paris.

Figure 2: Nicolas Lancret, Gallant Conversation, 1719. Oil on canvas, 68.3 x $53.5 \mathrm{~cm}$,

The Wallace Collection, London. 202

Figure 3: Antoine Watteau, Harlequin and Colombine (Voulez-Vous triompher des Belles?), c.1717. Oil on oak panel, 36 x $24.9 \mathrm{~cm}$, The Wallace Collection, London.

Figure 4: Nicolas Lancret, The Peepshow Man, 1743. Oil on Canvas, 52 x $77.5 \mathrm{~cm}$, Stifung Preußische Schlösser und Gärten, Berlin-Brandenburgh, Berlin, Scholss Charlotttenburg.

Figure 5: Antoine Watteau, La Marmotte, 1716. Oil on Canvas, $40.5 \times 32.5 \mathrm{~cm}$, The Hermitage Museum, Saint Petersburg.

Figure 6: Nicolas Lancret, Le Repas de Noce au Village (Wedding Celebrations in a Village), 1735. Oil on Canvas, 43.3 x $35.5 \mathrm{~cm}$, Musée d'Angers, Angers, France. MBAJ96J1881P. Photo : Beoît Touchard. CRMN-Grand Palais/Art Resource, NY. .206

Figure 7: Nicolas Lancret, The Wedding Breakfast, 1737-40. Oil on Canvas, 44.2 x 58.2 $\mathrm{cm}$, Waddesdon Manor, England. .207

Figure 8: Engraving after Antoine Watteau, Le repas de champagne (The Country Meal), c. 1700-1712. Original, 64.8 x $46.8 \mathrm{~cm}$, Trustees of the British Museum, London........208

Figure 9: Antoine Watteau, La Cuisinière (The cook), c. 1700-1712. Oil on Canvas, 53 x $44 \mathrm{~cm}$, Musée des Beaux-Arts, Strasbourg, France.

Figure 10: Engraving after Antoine Watteau, Retour de guinguette (Return from the Tavern), c. 1700-1712. Original 24.5 x $37.7 \mathrm{~cm}$, Trustees of the British Museum, London.

Figure 11: Attributed to Nicolas Lancret, La Chercheuse de Puces, c. 1720-1725. Oil on Panel, 29.7 x $25.5 \mathrm{~cm}$, The Wallace Collection, London.

Figure 12: Nicolas Lancret, La Cuisine, c. 1720-1730. Oil on Canvas, 40 x $33 \mathrm{~cm}$, The Hermitage Museum, Saint Petersburg.

Figure 13: Willem Kalf with additions by Nicolas Lancret, Kitchen Interior, c. 1645 / c.1735. Oil on panel, 25.4 x $21 \mathrm{~cm}$, photograph before conservation. The Saint Louis Museum of Art, Saint Louis, Missouri.

Figure 14: Nicolas Lancret, Le Nègre et La Cuisinière, c. 1720-1730. Location Unknown. 
Figure 15: Nicolas Lancret, Le Galant Valet, c. 1720-1730. Oil on Canvas, 40 x $32.5 \mathrm{~cm}$, The Hermitage Museum, Saint Petersburg.

Figure 16: Gerrit Dou, A Poulterer's Shop, ca. 1670. Oil on oak, 58 x $46 \mathrm{~cm}$, The National Gallery, London.

Figure 17: Joachim Beuckelaer, Market Scene, 1563. Oil on Oak, $111 \mathrm{~cm} \mathrm{x} 164 \mathrm{~cm}$, Residenzgalerie, Alte Residenz, Salzburg, Austria.

Figure 18: Antoine Watteau, Bivouac (Camp Volant), c.1710. Oil on canvas, 32.8 x 44.9 $\mathrm{cm}$, Pushkin Museum of Fine Arts, Moscow.

Figure 19: Antoine Watteau, The Respite from War (Les délassements de la guerre), c. 1712. Oil on copperplate, 21.5 x $33.5 \mathrm{~cm}$, The Hermitage, Saint Petersburg.

Figure 20: Engraving after Antoine Watteau, Départ de garnison (Depart of the Garrison). Original, 42.7 x $56.2 \mathrm{~cm}$, The Victoria and Albert Museum, London.

Figure 21: Nicolas Lancret, Military Camp. Private Collection of Mary Tavener Holmes.

Figure 22: Nicolas Lancret, Fête in a Wood, c. 1722. Oil on Canvas, 60 x $79.2 \mathrm{~cm}$, The Wallace Collection, London.

Figure 23: Nicolas Lancret, L'automne (Autumn), 1721-23. Oil on canvas, 113 x $94 \mathrm{~cm}$, Previously of the Homeland Foundation, Inc., Armenia, New York.

Figure 24: Antoine Watteau, Les fêtes vénitiennes, 1718-19. Oil on canvas, 55.9 x 45.7 $\mathrm{cm}$, National Gallery of Scotland, Edinburgh.

Figure 25: Antoine Watteau, Le Printemps, 1717/1718. Oil on Canvas, 119 x $98 \mathrm{~cm}$, Destroyed, formerly Collection of Lady Sybil Grant.

Figure 26: Louis Desplaces, Engraving after Antoine Watteau, Le Printemps. L'oeuvre d'Antoine Watteau (volume I), c. 1740, National Gallery of Art, Washington, Widener Collection, 1942.9.2092.

Figure 27: Antoine Watteau, L'Été, 1717/1718. Oil on Canvas, 141.6 x $115.7 \mathrm{~cm}$, National Gallery of Art, Washington D.C., Samuel H. Kress Collection.

Figure 28: Etienne Fessard, Engraving after Antoine Watteau, L'Automne. L'oeuvre d'Antoine Watteau (volume I), c. 1740, National Gallery of Art, Washington, Widener Collection, 1942.9.2092.

Figure 29: Antoine Watteau, sketch for L'Automne, 1713-1718. Oil on Canvas, 48 x 40.5 $\mathrm{cm}$, Musée du Louvre, Paris. 
Figure 30: Jean Audran, Engraving after Antoine Watteau, Winter. L'oeuvre d'Antoine Watteau (volume I), c. 1740, engraving, National Gallery of Art, Washington, Widener Collection, 1942.9.2092.

Figure 31: Engraving after Antoine Watteau, Le Lorgneur, 34.2 x 26.9 cm. London, Trustees of the British Museum.

Figure 32: Antoine Watteau, L'amour au théâtre françois (Love in the French Theatre), c. 1712. Oil on Canvas, 37 x 48 cm, Gemäldegalerie, Staatliche Museen zu Berlin Preußischer Kulturbes.

Figure 33: Gabriel Huquier after Antoine Watteau, L'Automne, Collection iconographique Maciet, série "Graveurs et ornemanistes, XVIe-XVIIIe siècle," album Watteau I, (Paris : Chez Huquier, 1734), Bibliothèque des Arts décoratifs, Maciet ORN/14/19-22.

Figure 34: Gabriel Huquier after Antoine Watteau, detail of L'Automne. Collection iconographique Maciet, série "Graveurs et ornemanistes, XVIe-XVIIIe siècle," album Watteau I (Paris : chez la Ve de F. Chereau, 1729), Bibliothèque des Arts décoratifs, Maciet ORN/14/23-24.

Figure 35: Antoine Watteau, L'Automne. Red chalk, 290 x 185 cm, The Hermitage

Museum, Saint Petersburg.

Figure 36: Nicolas Lancret, Spring, 1721-23. Oil on Canvas, 115.9 x $95 \mathrm{~cm}$, The Hermitage Museum, Saint Petersburgh.

Figure 37: Nicolas Lancret, Summer, 1721-23. Oil on Canvas, 115 x $95 \mathrm{~cm}$, The Hermitage Museum, Saint Petersburgh.

Figure 38: Nicolas Lancret, Winter, 1721-23. Oil on Canvas, 115 x $94 \mathrm{~cm}$, Private Collection.

Figure 39: Attributed to Antoine Watteau, Fêtes Galantes d'Automne. Château de Condé en Brie. Image courtesy of the author.

Figure 40: Attributed to Nicolas Lancret, Le villageois ayant perdu son veau from Jean de La Fontaine's fables. Château de Condé en Brie. Image courtesy of the author

Figure 41: Attributed to Antoine Watteau, A hunting party. Château de Condé en Brie. Image courtesy of the author.

Figure 42: Attributed to Nicolas Lancret, Figures in a landscape. Château de Condé en Brie. Image courtesy of the author.

Figure 43: Attributed to Antoine Watteau, Figure in a landscape. Château de Condé en Brie. Image courtesy of the author. 
Figure 44: Nicolas Lancret, La Terre, before 1732. Oil on Canvas, 38 x $31 \mathrm{~cm}$, Museo Nacional Thyssen-Bornemisza, Madrid.

Figure 45: Nicolas Lancret, L'Eau, before 1732. Oil on Canvas, 39.40 x $31.80 \mathrm{~cm}$, The National Galleries of Scotland, Edinburgh.

Figure 46: Nicolas Lancret, Le repas au retour de chasse, c. 1725. Oil on Canvas, $90.3 \mathrm{x}$ $123.5 \mathrm{~cm}$, Musée du Louvre, Paris. 246

Figure 47: Antoine Watteau, Le bal champêtre, 1713/1714. Oil on Canvas, 96 x $128 \mathrm{~cm}$, Private Collection. 247

Figure 48: Antoine Watteau, Les plaisirs du bal, 1715-17. Oil on Canvas, 52.6 x $65.4 \mathrm{~cm}$, Dulwich Picture Gallery, London. .248

Figure 49: Antoine Watteau, Rendez-vous de Chasse, 1717-1718. Oil on Canvas, $124.5 \mathrm{x}$ $189 \mathrm{~cm}$, The Wallace Collection, London.

Figure 50: Benoit Audran, Engraving after Antoine Watteau, Retour de chasse. Musée du Louvre, Paris. .250

Figure 51: Antoine Watteau, Huntress with Dogs, 1713-1714. Red chalk and brown pen on paper, 40.3 x $54.1 \mathrm{~cm}$, Städel Museum, Frankfurt.

Figure 52: Nicolas Lancret, Halte de Chasseurs, c. 1720-1730. Oil on Canvas, 86 x $107 \mathrm{~cm}$, Private Collection.

Figure 53: Nicolas Lancret, A Hunter and His Servant, c. 1737-1740. Oil on Canvas, 82.5 x $65 \mathrm{~cm}$, Private Collection.

Figure 54: Nicolas Lancret, La fin de chasse, c. 1720-1725. Oil on Canvas, 112 x 145 cm, Location Unknown .254

Figure 55: Nicolas Lancret, La Camargo Dancing, c. 1729-30. Oil on Canvas, 76 x 107 $\mathrm{cm}$, The National Gallery of Art, Washington D.C., Andrew W. Mellon Collection. ....255

Figure 56: Peter Paul Rubens, Garden of Love, c.1633. Oil on Canvas, $198 \mathrm{~cm}$ x $283 \mathrm{~cm}$, Prado Museum of Art..... .256

Figure 57: Peter Paul Rubens, Chateau in a Park, c. 1632/1635. Oil on Wood, 52.5 cm x $97 \mathrm{~cm}$, Kunstistorisches Museum, Vienna.

Figure 58: Peter Paul Rubens, Kermesse, c. 1630-1638. Oil on Panel, $149 \times 261 \mathrm{~cm}$, Musée du Louvre, Paris.

Figure 59: Hans Sebald Beham, Bauernfest (Kermis), c.1535. Woodcut, $38.9 \times 53.9 \mathrm{~cm}$, Graphische Sammlung der Universität Erlangen-Nürnberg. .258 
Figure 60: Antoine Watteau, La Mariée de village, c. 1710-12. Oil on Canvas, 65 x 92 $\mathrm{cm}$, Stifung Preußische Schlösser und Gärten, Berlin-Brandenburgh, Berlin, Schloss Charlottenburg.

Figure 61: Antoine Watteau, L'Accordée du village, c. 1708-1710. Oil on Canvas, $63 \mathrm{x}$ $92 \mathrm{~cm}$, Sir John Soane's Museum, London.

Figure 62: Willem Kalf, Kitchen Interior, c. 1645 / c.1735. Oil on panel, 25.4 x $21 \mathrm{~cm}$, photograph after conservation. The Saint Louis Museum of Art, Saint Louis, Missouri.

Figure 63: Esaias van de Velde, The fête champêtre, 1615. Oil on Canvas, $34.7 \times 60.7$ $\mathrm{cm}$, Rijksmuseum Amsterdam.

Figure 64: Nicolas Lancret, Le repas italien (The finished banquet), c. 1720, Oil on Canvas, 90 x $91 \mathrm{~cm}$, Stifung Preußische Schlösser und Gärten, Berlin-Brandenburgh, Berlin, Schloss Charlottenburg. Inv. No. GK I5658 Photo Credit: BPK Bildagenture/ Schloss Charlottenburg.

Figure 65: Nicolas Lancret, The Swing, 1723-27. Oil on Canvas, 150.80 x 89.70, The Cleveland Museum of Art.

Figure 66: Nicolas Lancret, Dance in a Garden, c.1730. Oil on Canvas, 59.5 x $50.8 \mathrm{~cm}$, Ackland Art Museum, The University of North Carolina at Chapel Hill.....

Figure 67: Nicolas Lancret, La danse dans le parc, c. 1720. Oil on Canvas, 116.5 x 105.5 $\mathrm{cm}$., Private Collection.

Figure 68: Nicolas Lancret, Une danse champêtre, c. 1740. Oil on Canvas, 43.5 x $36 \mathrm{~cm}$, Musée d'Angers, Angers, France.

Figure 69: Antoine Watteau, Le Cortège de fiançailles, c. 1710-1712. Location

Figure 70: Nicolas Lancret, The Village Wedding, 1737-40. Oil on Canvas, 44 x $57.5 \mathrm{~cm}$, Waddesdon Manor, England.

Figure 71: Pieter Bruegel, Peasant Kermis, c. 1567. Oil on Panel, 114 x 164 cm, Kunsthistorisches Museum, Vienna, Austria.

Figure 72: Pieter Bruegel, Peasant Wedding Dance, 1566. Oil on Panel, $119.4 \mathrm{~cm} \times$ $157.5 \mathrm{~cm}$, Detroit Institute of Arts, Detroit, Michigan.

Figure 73: Nicolas Lancret, Le printemps, 1738. Oil on Canvas, 69 x 89 cm, Musée du Louvre, Paris.

Figure 74: Nicolas Lancret, L'été, 1738. Oil on Canvas, 69 x 89 cm, Musée du Louvre, Paris 
Figure 75: Nicolas Lancret, L'automne, 1738. Oil on Canvas, 69 x $89 \mathrm{~cm}$, Musée du Louvre, Paris, INV5599. Photo: Stéphane Maréchalle. CRMN-Grand Palais/Art Resource, NY.

Figure 76: Nicolas Lancret, L'Hiver, 1738. Oil on Canvas, 69 x 89 cm, Musée du Louvre, Paris

Figure 77: Jan van de Velde, September, 1616. Etching, $15.9 \mathrm{~cm}$ x $30.5 \mathrm{~cm}$, Amsterdam, Rijksmuseum. .276

Figure 78: Pieter Bruegel, Wheat Harvest, 1565. Oil on Wood, 119 x $162 \mathrm{~cm}$, The Metropolitan Museum of Art, NY.

Figure 79: Pieter Bruegel, Return of the Herd, 1565. Oil on Wood, $117 \mathrm{~cm} \times 159 \mathrm{~cm}$, Kunsthistorisches Museum, Vienna.

Figure 80: Pieter Bruegel, Hunters in the Snow, 1565. Oil on Wood, $117 \mathrm{~cm} \times 162 \mathrm{~cm}$,

Kunsthistorisches Museum, Vienna...... .278

Figure 81: Bernard Audran, Engraving after Nicolas Lancret, Fire (from The Four Elements). c. 1732. Bibliothèque Nationale, Paris, Cabinet des Estampes.

Figure 82: Jean Mariette, Summer: St. John's Fire. Engraving, Bibliothèque Nationale,

Paris, Cabinet des Estampes. .280

Figure 83: Frontispiece from Philippe Sylvestre Dufour, Traitez Nouveaux \& Curieux du Café, du Thé et du Chocolate. (La Haye: Chez Adrian Moetjens, 1685). Bibliothèque nationale de France, département Sciences et techniques, 8-TC24-11 (A). .281

Figure 84: Guillaume Pigerone, Chocolatière, 1769, Musée des Arts Décoratifs, Paris, INV. 3485.

Figure 85: Chocolate pot, Meissen Manufacture, c. 1720. Musée des Arts Décoratifs, Paris, INV. 31910.

Figure 86: Examples of moulinets, from Sophie D. Coe and Michael D. Coe. The True History of Chocolate. (New York: Thames and Hudson, Inc., 1996), 116.

Figure 87: Teapot, Hard-Paste Porcelain, Meissen Manufactory, c. 1735-45. The Metropolitan Museum of Art, NY, INV. 02.6.120 ab.

Figure 88: Edme-Francois Godin, Théière, France, 1769. Musée des Arts Décoratifs, Paris, INV. 26907.

Figure 89: Cafetière, 1730-1780. Musée des Arts Décoratifs, Paris, INV. 29993.

Figure 90: Teabowl, Soft-Paste Porcelain, Saint-Cloud, c. 1715-1730. The Metropolitan Museum of Art, NY, INV. 02.6.69. 
Figure 91: Teacup, tin-glazed soft-paste porcelain, Chantilly Manufactory, c. 1735-1740. The Metropolitan Museum of Art, NY, INV. 1995.268.153.

Figure 92: Nicolas Bonnart, A Cavalier and a Lady Drinking Chocolate, engraving, from Costumes du règne de Louis XIV. Bibliothèque nationale de France, Cabinet des estampes.

Figure 93: Trembleuse cup and saucer, Hard-Paste porcelain, Du Paquier porcelain factory, Vienna, c. 1735-1740. The Victoria and Albert Museum, London, INV. C. 641949.

Figure 94: Tea, coffee and chocolate service, ca. 1740, Meissen porcelain. From Maureen Cassidy-Geiger, ed. Fragile Diplomacy: Meissen Porcelain for European Courts ca. 1710-63. (New Haven: Yale University Press, 2007), 226.

Figure 95: Nicolas Lancret, Les Heures du Jour: Le Matin, 1739. Oil on Copper, 28.3 x $36.4 \mathrm{~cm}$, The National Gallery, London.

Figure 96: Nicolas Lancret, Les Heures du Jour: Midi, 1739. Oil on Copper, 28.6 x 36.9 $\mathrm{cm}$, The National Gallery, London.

Figure 97: Nicolas Lancret, Les Heures du Jour : L'àpres-diner, 1739. Oil on Copper, 28.8 x $36.7 \mathrm{~cm}$, The National Gallery, London.

Figure 98: Nicolas Lancret, Les Heures du Jour : La Soirée, 1739. Oil on Copper, 28.8 x $36.8 \mathrm{~cm}$, The National Gallery, London.

Figure 99: Image from Alfred Franklin, La Vie Privee d'Autrefois : le café, le thé \& le chocolat. (Paris: E. Plon, Nourrit et Cie, Imprimeurs-Editeurs, 1893) Figure 1, 9.

Figure 100: : François Boucher, La Toilette, 1739. Oil on Canvas, 81.5 x $65.5 \mathrm{~cm}$, Musée du Louvre, Paris. .298

Figure 101: Jean-Baptiste Le Prince, Fear, 1769. Oil on Canvas, 50 x 64 cm, Toldeo Museum of Art, Toldedo, Ohio.

Figure 102: Nicolas Lancret, La petit déjeuner avant la chasse, c. 1740. Oil on Canvas, 61 x 133.4 cm, Fine Arts Museums of San Francisco, Legion of Honor.

Figure 103: Nicolas Lancret, Concert Champetre, c. 1740. Oil on Canvas, 61 x $128.9 \mathrm{~cm}$, Fine Arts Museums of San Francisco, Legion of Honor. .300

Figure 104: Nicolas Lancret, Le Fin de la Chasse, c. 1740. Oil on Canvas, 60.3 x 135.1 $\mathrm{cm}$, Fine Arts Museums of San Francisco, Legion of Honor.

Figure 105: Nicolas Lancret, Baigneuses, c. 1740. Oil on Canvas, 61 x 129.5 cm, Fine Arts Museums of San Francisco, Legion of Honor. 
Figure 106: Nicolas Lancret, A Lady and Gentleman with Two Girls in a Garden, 1742.

Oil on Canvas, 88.9 x $97.8 \mathrm{~cm}$, The National Gallery, London.

Figure 107: François Boucher, Le Déjeuner, 1739. Oil on Canvas, 81.5 x $65.5 \mathrm{~cm}$, Musée du Louvre, Paris.

Figure 108: Joseph Parrocel, The Boar Hunt, ca. 1700. Oil on Canvas, 109 x $104.1 \mathrm{~cm}$.

The National Gallery, London.

Figure 109: Nicolas Lancret, Les Plaisirs de bain, 1725. Oil on Canvas, 100 x $154 \mathrm{~cm}$.

Musée du Louvre, Paris. .305

Figure 110: Nicolas Lancret, Le Départ pour Cythere, c. 1719-1720. Oil on Canvas, 73.5 x $60 \mathrm{~cm}$, Stifung Preußische Schlösser und Gärten, Berlin-Brandenburgh, Potsdam, Schloss Sanssouci. 306

Figure 111: Nicolas Lancret, Le déjeuner de jambon, 1735. Oil on Canvas, $187.96 \mathrm{x}$ $133.05 \mathrm{~cm}$, Chantilly, Musée Condé.

Figure 112: Jean-François de Troy, Le déjeuner d'huitres, 1735. Oil on Canvas, $180 \mathrm{x}$ $126 \mathrm{~cm}$, Chantilly, Musée Condé. 308

Figure 113: Nicolas Lancret, Le déjeuner de jambon, 1735. Oil on Canvas, 55.7 x $46 \mathrm{~cm}$, Museum of Fine Arts, Boston. 309

Figure 114: Nicolas Lancret, Le déjeuner dans le foret, c. 1725 (1738). Oil on Canvas, 97 x $131 \mathrm{~cm}$, Stifung Preußische Schlösser und Gärten, Berlin-Brandenburgh, Potsdam, Schloss Sanssouci.

Figure 115: Nicolas Lancret, Le déjeuner dans le foret, c. 1725. Oil on Canvas, 55.9 x $73.7 \mathrm{~cm}$, Detroit Institute of Arts.

Figure 116: Nicolas Lancret, Le repas au chasse, c. 1735/1740. Oil on Canvas, $61.5 \mathrm{x}$ $74.8 \mathrm{~cm}$, National Gallery of Art, Washington D.C.

Figure 117: Nicolas Lancret, Fête galante entre une tente et une rivière, 1740. Oil on Canvas, 60.8 x $75.2 \mathrm{~cm}$, Museum Huis Doorn, Netherlands. 


\section{Introduction}

\section{Overview}

Dining is inarguably one of the oldest, most prevalent and pervasive acts of social interaction. In the modern age the ability to display one's taste or refinement with regard to fashionable or trendy food items has become immediate due to social media. Instagram is filled with pictures of food: from farmers' markets to prepared meals to selfies holding food. The foodstuff that people show themselves eating or getting ready to eat are indicators of their social identities and how they would like to be perceived by others. These food items also carry connotations ranging from rustic to luxurious or processed versus fresh, i.e. fried chicken compared to caviar or canned tuna in contrast to wild caught salmon. However, in our current culinary climate even the lowest of foods have been redeemed and made fashionable again - think Spam fried rice. Paintings of food during the eighteenth century can be viewed in a comparable way. The items depicted by the artist(s) have certain social connotations and long-standing iconographic affiliations. The paintings of food both reflect how the patron or subject of the painting wanted to be interpreted or perceived and blur the lines between popular and court culture.

Food is a key element in hunt luncheon scenes, a new type of fête galante created by the eighteenth-century artist Nicolas Lancret (1690-1743). While this dissertation is ultimately concerned with the creation of this new genre scene, the incorporation of food items is essential to the subject of the paintings and their incorporation into paintings was novel. I have sought to understand how Lancret came to formulate this new genre and to investigate the numerous influences involved in the process of its creation. Additionally, I discuss how dining was an aspect of elite sociability within the hunt luncheon paintings, 
situated within both the contexts of elite social performance and artistic production in eighteenth-century France.

Nicolas Lancret was a very prolific artist who, while very popular during his life, has often been left out of the discussion of eighteenth-century art. Instead, he has been discussed short-sightedly as a mere follower of the formative Rococo artist, Antoine Watteau (1684-1721). While it is the case that Lancret owes a debt to Watteau artistically by mirroring Watteau's training and technique early in his career, scholar Mary Tavener Holmes has shown how Lancret moved past the elder artist's early influence to achieve his own style easily distinguishable from Watteau's. Lancret also modeled his business of artmaking off of Watteau's example, bringing himself into the same cultural milieu and obtaining many of the same patrons. Like Watteau, the numerous prints after his paintings were immensely popular and had a wide distribution.

Since Lancret's early artistic career and training is so similar to Watteau's, much of the discussion of his biography which would normally appear here in the Introduction I save for the first chapter. Like most artists of his time, Lancret attended the Académie Royale de peinture et de sculpture. He had numerous patrons, including many crowned heads of Europe, the French nobility, and wealthy financiers. It does not appear that he ever had a studio or took younger artists under his care as did Watteau with Jean-Baptiste Pater (1695-1736) or François Lemoyne (1688-1737) did with François Boucher (17031770). Lancret was a prolific draughtsman as many artists of the time were. However, he seems to have preferred his artistic independence and only had a small circle of friends. He married at a rather old age a woman twenty years younger, Marie Boursault (ca 1710- 
1782), in 1740 at his age of fifty. The couple had no children. Their marriage only lasted three years and ended upon the artist's death in 1743 .

As a young artist Lancret was perfectly situated with in the academy to watch the trajectory of Watteau's upsurge in popularity. He would have been keenly aware of the market and academic conditions that facilitated Watteau's rise. It is obvious that Lancret was astute enough to realize and to emulate how the elder artist achieved success. Not only did Lancret purposefully shift from the studio of a history painter to that of a genre painter, he saw the influences on Watteau's paintings and emulated the way the elder artist assimilated the various sources available to him to create a new genre. Lancret was also acutely aware of market conditions in relation to the demand for smaller genre paintings and the vogue for scenes inspired by Northern artistic traditions. He was able to expertly combine the social aspects of the aristocracy with the settings and subjects of Northern paintings to create a hybrid that had a resounding appeal to collectors. The artist was similarly an astute business man; in 1730 he petitioned the crown for and was granted the rights to engrave and sell prints after his paintings for a period of six years. ${ }^{1}$ In an interesting early instance of copyright law, the engraver Joseph Limosin was arrested and made to pay restitution to Lancret for his forged engravings; the marchands imagers Pierre Sirois and Nicolas Galtrot and the revender d'images Antoine Radigue were also implicated in the scandal. ${ }^{2}$

Lancret's creation of the hunt luncheon drew primarily on Watteau's work and the development of the fête galante. However, Lancret was also familiar with the same artistic sources that Watteau assimilated to create this new type of painting: Dutch and

${ }^{1}$ J.J. Guiffrey, Éloge de Lancret, peintre de Roi (Paris : Rapilly, c. 1874), 66-67.

${ }^{2}$ Guiffrey, Éloge de Lancret, peintre de Roi, 66-76. 
Flemish paintings, Italian theatre troupes, and contemporary French fashions and dress. While Watteau's reputation as the inventor of the fête galante has been canonized into the history of art, Lancret's status suffered greatly during the nineteenth and twentieth centuries, despite his popularity and success during his own lifetime.

The depiction of hunt luncheons during the eighteenth century is a much larger topic than just the paintings of Lancret. Carle van Loo (1705-1765), Jean-François de Troy (1679-1752), François Lemoyne, François Boucher, and many lesser known artists depicted similar dining scenes. However, no artist did so with as much frequency as did Lancret. Thus, this dissertation is in no way comprehensive of the theme, nor is it the final word on the artist and this subject. The further investigation of all of these images together is perhaps the next logical development and a much larger project.

The appearance of painted hunt luncheon scenes during the eighteenth century in France is rather anomalous. They do not appear with any frequency in earlier periods of French art, with the exception of medieval manuscript illuminations and woven tapestries. As I have argued elsewhere, the developments in domestic architecture were partially responsible for the appearance of dining as a subject in paintings during the eighteenth century. Additionally, multiple other factors play into the popularization of the hunt luncheon; the luxury of the aristocracy, the play of leisure, and the imagined and romanticized simplification and rusticity of a bucolic ideal are only some aspects of these works. On the other hand, the pervasiveness of such representations of the hunt, dining, and the luxury food items these paintings often depict is in part due to the ongoing efforts of the aristocracy to distinguish itself from the ever-present threat of the rising bourgeoisie. These concerns are found in the paintings by Nicolas Lancret. 
While the focus of the dissertation is the creation of the hunt luncheon, I discuss instances of comestibles by Lancret; painted representations of people eating or enjoying coffee, tea, or chocolate also play into the performative aspects of social status in the eighteenth century and parts of the rituals of the hunt. Additionally, eighteenth-century sources on dining and hunting etiquette and traditions help to illuminate the prevailing social customs of the period, ranging from what was consumed to how it was consumed. These sources help to further explain the subjects that Lancret painted and show how these representations reflected the prevailing notions of idealized social interactions in paintings versus real-life instances. Finally, by situating the paintings within their originally intended sites within the complex architectural framework of eighteenthcentury noble residences, I hope to show how these paintings may have influenced the people who saw, purchased, or displayed the objects, and who understood the aspects of elite sociability they demonstrated. Therefore, I use these paintings and the social customs they depict to elucidate one another.

Recent scholarship has taken up the aristocratic ritual of the hunt, such as JulieAnne Plax's essay, "Fêting the Hunt in Eighteenth-Century Painting." and Amy Freund's essay "Men and Hunting Guns in Eighteenth-Century France," but scholars have not addressed images of the hunt in relation to the numerous artistic depictions of a halte or repos during the ritual in which food was consumed. Other scholarship on Nicolas Lancret focuses on his depictions of the elite social activities of the fête galante, dancing, and games. Scholarship on other eighteenth-century artists has additionally included the social aspects of music, fashion, and the salons of the period. The discussion of the subject matter 
of these paintings, and the various accessories they depict serves as a backdrop to contextualize and explain the social dimensions of the hunt in eighteenth-century France.

Art historians of the eighteenth century have only minimally addressed depictions of dining. The discussion of depictions of dining typically takes the form of catalogue entries for various exhibitions or collections. One such example of this is the entry on Lancret's Le déjeuner de jambon in the collection catalogue of the Museum of Fine Arts, Boston. Another type of publication is the handbook or index of the various iconography and imagery associated with food and dining. Food and Feasting in Art from the Getty series A Guide to Imagery falls into this category, as does Kenneth Bendiner's book Food in Painting. However, these publications, even when addressing Lancret's works specifically, only discuss the paintings superficially and do not take into account his depiction of the social act of dining as an elite activity.

\section{Chapters and Organization}

Chapter One starts with a short discussion of Nicolas Lancret's artistic training and early production that are vital to understanding his artistic development and the potential influence of other artists or genre themes on his oeuvre. It is here that I expand upon the influence of Watteau in relation to Lancret's early works, including a painting of the hunt entitled La fin de chasse. This painting epitomizes Lancret's earlier emulation of Watteau's style and subject matter. While this work does not actually depict a dining scene, its resemblance to Watteau's painting Rendez-vous de Chasse is remarkable. It is possible that Rendez-vous de Chasse first influenced Lancret's work on hunting scenes which developed into paintings of hunt luncheons, the subject of the second chapter. The work entitled Le repas au retour de chasse in the collection of the 
Louvre shows how the younger artist emulated the elder but moved away from him in his choice of subject matter. This chapter focuses primarily on how Lancret differed from Watteau by including food items that illuminate the subject of the scene depicted as opposed to simply being used as props. Since Lancret has often been seen as a mere follower of Watteau, it is important to establish how and why his artistic production differed from the creator of the fête galante genre.

Next, the dissertation turns to images depicting village wedding scenes or outdoors feasts; these are the paintings that presumably influenced the setting and the subject of the hunt luncheon paintings. With regard to the village wedding scenes, $L e$ Repas de Noce au Village at the Musee d'Angers and The Wedding Feast in the collection of Waddesdon Manor in England, the influence of Northern Renaissance and Baroque genre scenes must be taken into account seriously as they were influential in the development and transmission of such genre scenes into a French idiom. Even though such wedding scenes typically depicted the lower classes in such works by Pieter Bruegel (1525/30-1569), Lancret adapted the subject for a more fashionable elite society as indicated by the dress of the numerous participants. Additionally, the paintings Le repas italien and L'automne also depict outdoor scenes of dining or picnicking. Le repas italien depicts the continued influence of Watteau on Lancret's choice of subject matter, while L'automne, a painting from a series on the seasons, is another example of genre scene with its roots in the north. The placement of these works within an architectural setting is important for the understanding of their originally intended audience and their possible effects on the viewers. 
The group of images discussed in Chapter Three depict the drinking of hot beverages. Depictions and the consumption of coffee, tea, and chocolate proliferated during the eighteenth century, and the three were an integral part of an aristocratic or wealthy bourgeoisie person's daily routine and dining habits. These hot beverages were luxury drinks first consumed and popularized by the crown and aristocracy and were included in the various aspects of elite sociability such as the hunt. The investigation into these paintings further clarifies the idealization of painted representations of social graces as opposed to the enacted practices of the hunting ritual and beverage consumption. The Four Times of Day: Morning and A Lady and Gentleman with Two Girls in a Garden both at the National Gallery in London are two well-known paintings by Lancret that depict this social practice. The overdoor La petit déjeuner avant la chasse in the collection of the Fine Arts Museum of San Francisco uses the theme of hunting and meals combined with the social aspects of fashionable beverages. While the original placement of all the paintings discussed in this dissertation is important to the understanding of how these painting may have been viewed or interpreted, the architectural framework of The Four Times of Day: Morning and La petit déjeuner avant la chasse is even more significant given that the paintings were both originally part of two sets of overdoors.

Nicolas Lancret achieved patronage by the king of France, something that Watteau did not accomplish during his short life. The final chapter focuses on the hunt luncheons beginning with a commission by the Bâtiments du Roi on behalf of Louis XV (1710-1774) for his private dining room at Versailles. Lancret's painting Le déjeuner de jambon, now in the collection of the Musée Condé in Chantilly, marks a definite break 
with the languid, fluid brushstroke of Watteau's. With this work, and a similar painting at the Museum of Fine Arts, Boston, Lancret developed a new type of fête galante subject, the hunt luncheon. The commissioning of Le déjeuner de jambon is also related to the new architectural development of the salle à manger and therefore must be understood within the context of this new development. Lancret painted a number of other works in this genre which this chapter discusses in detail.

The organization of this dissertation is not strictly chronological, and the timeline of the chapters tends to overlap given their organization around subjects. They do, however, retain a sense of chronology not just within the chapters themselves but throughout the entire dissertation. For instance, the first chapter covers Lancret's early period of production from roughly 1712 to 1725 , while the second chapter discusses works from 1725 to1740. Chapter Three discusses paintings completed toward the end of the artist's life as a means of showing how the artist incorporated beverages into the hunt luncheon paintings. Chapter Four is the examination of the culmination of the hunt luncheon genre and includes paintings which span the years from 1725 to the years just before Lancret's death. Lancret did not overtly continue to follow Watteau's example later in his career as he had earlier, nevertheless, there are hints of Watteau's influence from Lancret's early productions that reappear in his later more mature works.

\section{Scholarly Context}

Upon his death, numerous biographies of Lancret were published. The most extensive one was written by Silvain Ballot de Sovot (d. 1761) who has a friend of the artist. Ballot's Éloge de Lancret, peintre de Roi is an important source on his artistic 
training, life, and career. However, Ballot's account of his friend's life lacks a clear chronology and is by no means an exhaustive biography. Ballot shows his bias at times by praising Lancret and discussing his artistic merit and works with grandiose language. Other contemporary publications on the artist include Antoine-Joseph Dézallier d'Argenville's (1680-1765) Abrégé de la vie des plus fameux peintres, which was published in 1762 and prophesied that Lancret's paintings would stand the test of time better than Watteau's. ${ }^{3}$ The artist was also briefly mentioned by Edmé-François Gersaint (1694-1750) and Jean Mariette (1694-1774) and included in J.J. Guiffrey’s 1874 reprinting of Ballot's eulogy. Gersaint and Mariette's biographies on Lancret are harshly critical of the artist: Gersaint claimed he lacked the same finesse and delicacy of Watteau while Mariette called him repetitious and condemned his coloring. ${ }^{4}$ Guiffrey himself states that Lancret lacked the same vivacious imagination, originality, and charm of Watteau. ${ }^{5}$ Guiffrey's comments reflect the status of Rococo art during the nineteenth century, but Gersaint and Mariette's commentary may be indicative of their obvious bias for Watteau. Gersaint was Watteau's final patron, close friend, and the artist lived with him for a number of years. Mariette was a printmaker who may have held a grudge against Lancret because the artist retained the rights to print engravings after some of his most famous paintings, including that of Madame de Carmago, the famed dancer. Furthermore, Mariette most likely knew Watteau personally through Pierre Crozat (1665-1740), the wealthy financier.

\footnotetext{
${ }^{3}$ Antoine-Joseph Dézallier d'Argenville, Abrégé de la vie des plus fameux peintres tome 4 (Paris : Chez de Bure, 1762), 439.

${ }^{4}$ Guiffrey, Éloge de Lancret, peintre de Roi, 34-35.

${ }^{5}$ Guiffrey, Éloge de Lancret, peintre de Roi, 10.
} 
Regarding modern scholarship on Nicolas Lancret, Georges Wildenstein's 1924 publication on the artist remains the most complete monograph on him to date. Wildenstein's biography of Lancret draws upon the writings of the artist's friends after his death. Ballot, d'Argenville, and Auguste Jal's (1795-1873) writings serve as Wildenstein's primary sources for information on the artist. Despite providing a good chronology of the artist's life, Wildenstein's monographic style does not allow for an extended discussion of the various artistic and social influences that affected Lancret's production. While Wildenstein does discuss some artistic and social influences, he focuses mainly on the theatre and only briefly mentions artists other than Watteau. However, he does fill in some of the chronology that Ballot lacks, acknowledges the advantages of Lancret's being a native Parisian and the artist's access to collections including the grands Maîtres as having influenced him.

Mary Tavener Holmes is the principal American scholar on Lancret. Holmes has written a book and co-authored an exhibition catalogue in English. She has also coauthored a book and published numerous articles in French and catalogue entries in German. Her research on the artist includes Lancret's connections to Watteau and fêtes galantes, his depictions of dance, and his patronage by various royal figures of the European courts. Holmes makes many insightful and clearly articulated arguments about the early influence of Watteau on Lancret's work and Lancret's eventual shift away from the elder artist's style to one of his own personal expression. In this way Holmes provides a critical investigation of Lancret's works that Wildenstein lacks. Holmes's various publications delve into deeper social, economic, and artistic issues of the eighteenth century but are in no way comprehensive, and they leave much room for expansion. 
Modern scholarship on Watteau blossomed in 1984 with the publications of Donald Posner, Marianne Roland Michel, and Margaret Morgan Grasselli, Pierre Rosenberg, and Nicole Parmantier. Posner's Antoine Watteau examines the life of the artist, his paintings, and drawings. Posner enumerates the various influences on Watteau's production, from Northern Genre scenes to the theatre, his time at the Académie, and his formulation of the fête galante. Roland Michel's Watteau, An Artist of the Eighteenth Century delves into his artistic training and technique; his patrons, dealers, and collectors; and the various elements and aspects of his fêtes galantes. Grasselli, Rosenberg, and Parmantier's Watteau: 1684-1721 is a catalogue from the first international exhibition ever devoted to the artist. The exhibition catalogue includes an index of Watteau's friends and dealers, a chronological investigation of the artist's life, a catalogue of drawings, one of etchings made by the artist himself, and one of paintings. All three of these books provide the basis for numerous other thematic investigations into the artist's work though much of his life remains a mystery.

Mary Vidal's 1992 Watteau's Painted Conversations examines Watteau's paintings in relation to conversation, interpreted as a social gathering or verbal discourse at such gatherings. Vidal claims that Watteau's subjects are elitist means of social distinction and that Watteau was relating his artistic production to those of the aristocracy's use of artifice in personal representation. Julie-Anne Plax's Watteau and the Cultural Politics of Eighteenth-Century France (2000) uses many of the same paintings as Vidal to explore how the artist questioned the spaces between official ideology and the lived experience during the period. Plax argues that Watteau's paintings were subversive in nature and included internal inconsistencies and contradictions. Mary Sheriff edited a 
2006 volume of essays entitled Antoine Watteau: Perspectives on the Artist and the

Culture of his Time which explores various aspects of the artist's life and career. Included are essays by both Vidal and Plax. The subjects of the essays range from how Watteau has been interpreted over time to his passion for theatre, clothing, and his relationship with Gersaint. The volume is not intended to be the definitive work on the artist, but it is meant to investigate his artistic production through numerous interrelated perspectives and display the flexibility with which his works can be interpreted. Most recently Aaron Wile's 2016 exhibition catalogue, Watteau's Soldiers: Scenes of Military Life in Eighteenth-Century France explores Watteau's scenes of military life which focus on the experience of French soldiers. Wile examines the numerous drawings that the artist did presumably in preparation for the paintings in relation to ideas about interiority and developments in ideas of human subjectivity during the time.

\section{The Hunt}

Depictions of the hunt are as old as the activity itself. One of the earliest known artistic representations of the act appears in the Lascaux caves in southwestern France and date to seventeenth-thousand years ago. ${ }^{6}$ In more modern times, Gaston Phebus' $L a$ Livre de Chasse written in the late 1380s served as a standard text on the subject during the medieval period. The book included numerous illustrations depicting the diverse types and aspects of the hunt. Multiple copies of the manuscript were made and various renditions of it appeared afterwards. Other than manuscripts, tapestries were also a popular medium for the depiction of the hunt. Les Belles chasses de Maximilien was a

\footnotetext{
${ }^{66}$ The Chauvet cave in southern France dates to thirty-two-thousand years ago but scholars typically interpret the depictions of animals as having a ritual or magical intent as opposed to scenes of hunting.
} 
series of tapestries showing twelve hunting scenes arranged by month including their corresponding zodiac sign.

Eighteenth-century French texts relating to hunting abound most of which are simply copies of previous published works. Amy Freund has recently noted that more than fifty treatises on the topic were published in a three-hundred-year period. ${ }^{7}$ Important primary texts on the subject include Robert Salnove's 1665 treatise on hunting, entitled La vénerie royale, discusses the chasse à courre, the most noble of the various hunts; L'art de la Chasse by Antoine Trémolières de St. Saturnin, published in 1724, was aimed at an elite reader and focused on primarily on petit chasse. and Antoine Gaffet's Nouveau traité de vénerie of 1750 focuses on the history of the hunt and its use in training for warfare. The 1788 publication Traité de vénerie was written by a Monsieur d'Yauville, who was the premier veneur, or first-huntsman, and former commander of the king's hunting party.

Philippe Salvadori's 1996 La chasse sous l'ancien régime and Michael Aradas' $2003 \mathrm{PhD}$ dissertation, The Etiquette of Social Violence: Hunting and Nobility in Early Modern France are recent seminal works on the hunt. Scholars continually note Salvadori's study as the preeminent source for information on the rituals and rules of hunting during the sixteenth century until the death of Louis XIV. Aradas investigates the ways in which the hunt transformed during the three-hundred-year period beginning with the waning of the medieval period into the mid-eighteenth century. The author includes a

\footnotetext{
${ }^{7}$ Amy Freund, "Men and Hunting Guns in Eighteenth-Century France," in Materializing Gender in Eighteenth-Century Europe, ed. Jennifer G. Germann and Heidi A. Strobel (Burlington, VT: Ashgate Publishing Company, 2016), 17.
} 
discussion of hunting imagery, ranging from paintings and sculptures to woodcuts and tapestries as evidence of how the nobility negotiated changing social boundaries among themselves, the nouveaux riches, and the rest of society.

Art Historical research, such as Freund's aforementioned essay, examines how the rich ornamentation of an eighteenth-century hunting rifle evokes themes of violence, war, and sex. She carefully examines the masculinity enacted by the gun's ornament and how it related to the man who would have used it. Plax takes a different route altogether in her previously mentioned essay that examines the social aspects of the hunt through three eighteenth-century paintings depicting the hunt, a history painting, a fête galante, and a portrait.

While Lancret has been credited with inventing the hunt luncheon genre, there has been no known comprehensive study of its creation or discussion of the various influences that the artist incorporated into the genre. This dissertation fills this gap in this literature. The paintings discussed here are extant examples of such works. Wildenstein's monograph includes over twenty-one entries that could be deemed hunt luncheons or hunt fêtes, yet many of the works are lost, duplicates, or mentioned in old sale and auction catalogs whose actual whereabouts are unknown.

\section{Food and dining}

As previously noted, many recent publications focus on the various aspects of elite eighteenth-century French sociability including their representation in painting. This dissertation seeks to draw from these examples and expand on their conclusions of the 
performative aspects of social identity and status as well as the ability of the artist to create paintings open to multiple and varied interpretations. I aim to fill a gap in the arthistorical literature on the social act of dining. While no American scholars have dealt extensively with painted representations of dining in eighteenth-century French art, recent publications have utilized painted representation of dining scenes to illustrate their arguments. The Bibliothèque Nationale de France recently published Palais Royal: à la table des Rois. While not specifically about dining in art, the book does include numerous illustrations, prints, and paintings in its discussion of royal manners and consumption. Other recent publications on dining in art, such as A Feast for the Eyes, use paintings or reproduced prints to illustrate a cookbook full of modern versions of century-old recipes. The great advances in table settings, etiquette, and cooking make the early modern period one that is fruitful for research of this type.

Sources such as a 1705 printing of François Massialot's Le Cuisinier Rö̈al et Bourgeois, Vincent La Chapelle's Le Cuisinier Moderne (1735), and Joseph Gilliers's Le Cannameliste Français (1768) provide a foundation from which knowledge of eighteenth-century food preparation and presentation can be drawn. The Mémoires of the Duc de Luynes, Charles-Philippe d'Albert (1695-1758), also serve as a source of information on when, how, and where not only the Duc and his family dined, but also King Louis XV. Newer publications such as Susan Pinkard's A Revolution in Taste: The rise of French Cuisine and Barbara Ketcham Wheatson's Savoring the Past: The French Kitchen and Table from 1300-1789 build upon the earlier works of Jean-Francois Revel's Culture and Cuisine: A Journey Through the History of Food and Stephen Mennell's All Manners of Food: Eating and Taste in England and France from the Middle Ages to the 
Present. The basis for all these works are the monumental publications of French food historian André L. Simon.

My aim is to combine the two areas of study to examine the ways in which the idealized artistic social representation of dining relates to the food items depicted in the paintings. By viewing these paintings through an eighteenth-century lens, they will give insight into the social act of dining and its importance to the period. Furthermore, by researching cultural norms of what was eaten and how, I hope to explore Lancret's deviations from and adherence to the eighteenth-century model of dining. Of primary concern to this dissertation is how the meanings of these paintings are produced, made, and remade according to the viewers' own experiences. Additionally, the ways in which the artist used paintings to break down the spaces between official ideology and the lived experience is important to the discussion of how these works about have been interpreted during the eighteenth century.

\section{Theoretical Framework and Methodology}

Mary Sheriff's 1990 book Fragonard: Art and Eroticism provides an example of a semiotic reading of images. This type of reading suggests that the painting is a signifier of the appropriate social acts which were meant to take place in the spaces the paintings were originally intended to occupy. To this end, the paintings were an idealized suggestion of how the viewer should act in certain social situations. Such a reading is similar to the one that I reveal in the discussion of the works selected for this dissertation. The reciprocity of the action depicted in the works and their enactment by the owners of 
the paintings are crucial to understanding the social aspect of eighteenth-century French society and the paintings it engendered.

Following Sheriff's example is Julie-Anne Plax's previously mentioned book on Watteau; like Sheriff, Plax uses a revised form of the monograph to examine select works by the artist. However, Plax maintains a chronology throughout her discussion of the chosen works to show how the artist continued to use various themes and subjects to confound traditional conventions and categories. Plax's work stands not only as a model of organization for my own, but also provides a methodology for examining how artworks conform to or deviate from accepted social norms regarding class boundaries; the manipulation of cultural, social, and painterly codes of representation; and the absorption of both popular and high culture.

Sociologists have also tackled the social aspect of dining, more specifically, the various types of food which make up a meal. Most notably, Roland Barthes has argued that meanings of and values associated with food change over time. He sees food as a type of communication with various principles and signifiers attached to certain products or types of production. ${ }^{8}$ These are key concepts to keep in mind when discussing dining habits centuries predating our own. Additionally, Jean-Claude Bonnet has discussed the culinary aspects of the Diderot's Encyclopédie, including the organization and structure of entries relating to food and its preparation, history, and culinary practices. Bonnet notes how these aspects tie into thought patterns and intellectual tendencies of the

\footnotetext{
${ }^{8}$ Roland Barthes, "Toward a Psychosociology of Contemporary Food Consumption" in Food and Drink in History edited by Robert Forster and Orest Ranum, translated by Elborg Forster and Patricia M. Ranum (Baltimore: The Johns Hopkins University Press, 1979).
} 
period. ${ }^{9}$ These types of theories have not been applied to the artistic production of the eighteenth century, despite the ways in which sociological literature may serve to illuminate the types of food artists chose to depict in their works.

\section{Eighteenth-century discourse}

As with many artists of the eighteenth century and the Rococo period, Lancret's paintings are often rife with amorous intentions and veiled or explicit eroticism. This is a thread that weaves its way through all the chapters of this dissertation. Another continuous theme is the comparison with other eighteenth-century artists, especially Watteau, which helps to elucidate the ways in which Lancret set himself apart from his fellow artists both stylistically and with his subject matter.

In addition to the investigation of food, hunting practices, and sociability, this dissertation focuses on the larger question of how an artist creates a new genre. I have investigated how Lancret developed the depiction of the hunt luncheon through the combination of hunting portraits and subjects, traditions of Northern genre paintings, and the adaptation and manipulation of others artistic developments. The market conditions and the artist's ability to capitalize on Watteau's success speak to his acumen as a businessman and an artist.

Joan DeJean argues that the shift from culinary traditions to gastronomy (the science of good eating) during the latter part of the seventeenth century into the

\footnotetext{
${ }^{9}$ Jean-Claude Bonnet, "The Culinary System in the Encyclopédie" in Food and Drink in History edited by Robert Forster and Orest Ranum, translated by Elborg Forster and Patricia M. Ranum (Baltimore: The Johns Hopkins University Press, 1979).
} 
eighteenth helped to transform France into a modern nation with its own unique identity. ${ }^{10}$ Food was "essential to the new civilization of good (French) taste" with Paris at the center. ${ }^{11}$ French food and dining habits were quintessential marks of luxury and elegance. This aspect of Frenchness is one seen in the paintings by Lancret discussed throughout this dissertation. Viktoria von Hoffman's From Gluttony to Enlightenment focuses more on the sociology of food consumption during the period and demonstrates the various ways in which the early French notion of taste was developed and interpreted. Von Hoffman discusses how eating as a physical necessity was just as much a matter of personal comportment as dress and manners; it was simply another aspect that had to be learned and controlled. Von Hoffman is indebted to Norbert Elias's notions of the civilizing process and court etiquette.

\section{Conclusion}

Lancret is often condemned as being a follower of Watteau; however, his condemnation is the very thing for which Watteau is praised: taking the innovations of artists before him, reformulating and adapting various aspects, and creating a new genre. Lancret is often left out of the trio of eighteenth-century painters: Watteau, Boucher, and Fragonard. Lancret was more than a decade older than Boucher, who was not admitted to the academy until 1731. Additionally, much of the pastoral idealism of Boucher's paintings is found in Lancret's earlier works. Lancret is therefore not a mere follower

\footnotetext{
${ }^{10}$ Joan DeJean, The Essence of Style (New York: Free Press, 2005), 7-9.

${ }^{11}$ DeJean, The Essence of Style, 108.
} 
but a key figure in the transference and continuation of major themes and subjects in eighteenth-century French painting. This investigation proves this idea. 


\section{Chapter One - Watteau's Influence on Lancret's Early Works}

Lancret works with a limited repertoire or physiognomic types and psychological situations...This picture, [La danse devant la tente]...is one of the most accomplished works by the artist. Watteau's entire repertoire can be found in it...Lancret has kept Watteau's inventions without either attempting to understand their true lesson or to renew their significance. ${ }^{12}$

Pierre Rosenberg

\section{Overview}

The influence of Antoine Watteau (1684-1721) on the early training and career of Nicolas Lancret (1690-1743) is well known to art historians. Lancret has often been pejoratively dismissed as a follower of Watteau. While this may be true to a certain extent earlier in his career, Lancret developed his own signature style that takes him out of the realm of merely a follower and into an artist who possessed his own unique visual idiom. Despite this, Lancret's oeuvre contains many instances where the influence of Watteau can readily be seen; it is not necessarily in the way Lancret chose to paint that separates him from the older artist but, rather, his subject matter.

Though the artists had some of the same patrons, for the most part they developed separate spheres that spoke to their varied nature as artists despite the continued modern dismissal of Lancret as an imitator of Watteau. The interpretation of Lancret as a "formulaic imitator(s)" of Watteau is not a true representation of the artist's intentions or achievements. ${ }^{13}$ Even during his own time Lancret was often cited as a follower of Watteau; however, this should not be seen as a pejorative dismissal by his contemporaries of his artistic abilities but rather a means of acknowledging that Lancret was following

\footnotetext{
${ }^{12}$ Pierre Rosenberg, The Age of Louis XV: French Painting 1710-1774 (Toledo, Ohio: The Toledo Museum of Art, 1975), 51.

${ }^{13}$ Thomas Crow, Painters and Public Life in Eighteenth-Century Paris (New Haven \& London: Yale University Press, 2000), 73.
} 
the ground-breaking innovations of the elder artist. Therefore, Lancret painting in the goût Watteau is simply a descriptor similar to an artist painting in the goût moderne and not an indictment of the artist's lack of ability or originality.

Nicolas Lancret's life and early training have been well documented by several scholars. Georges Wildenstein's 1924 monograph on the artist long stood as the only scholarly work on Lancret. Mary Tavener Holmes addressed him more recently in a 1991 co-authored exhibition catalogue, Nicolas Lancret, 1690-1743, and a book, Nicolas Lancret, Dance Before a Fountain, published in 2006. Both of these authors draw on the writings of Silvain Ballot de Sovot's biography of the artist, Éloge de Lancret, peintre de Roi, Antoine-Joseph Dézallier d'Argenville's Abrégé de la vie des plus fameux peintres, and Auguste Jal's Dictionnaire critique de biographie et d'histoire, among other sources. Since Holmes's scholarship is the most recent work on the artist, and also draws on Wildenstein's, it serves as the most comprehensive and up-to-date source for the information on Lancret's early training and career. Additionally, Holmes makes many insightful and clearly articulated arguments about the early influence of Watteau on Lancret's work and Lancret's eventual shift away from the elder artist's style to one of his own personal expression.

\section{Eighteenth-Century French Society}

Nicolas Lancret appeared on the Parisian artistic scene at a time when the social and political restrictions on artistic production were being relaxed. The Académie Royale de Peinture et de Sculpture was established in 1648 as a means to regulate artistic production under the absolutist state. Louis XIV (1638-1715) controlled all of French 
society, including the arts. The Académie acted much like a clearing house for artists learning to paint in a manner dictated by the king through its director, Charles Le Brun (1619-1690). Much of an artist's training was centered on producing works that the crown would want to purchase since Louis XIV was the largest commissioner and patron of the arts.

It was only after the death of the Sun King in 1715, during the Regency of Philippe d'Orléans (1674-1723), that artists were able to move away from this crowncentered production to one based more on a market economy. Shortly after Louis XIV's death, Philippe left Versailles with the young Louis XV (1710-1774) in tow and returned to Paris. The aristocracy soon followed and began building or renovating Parisian townhomes which required decoration and ornamentation. Painters then found themselves in a situation where art works were commissioned primarily to decorate these private town homes. This meant a demand for smaller, more intimate images than the large-scale, lofty subjects that decorated the grand châteaux of the royalty.

The Regent's libertine lifestyle varied greatly from that of his uncle and father-inlaw, Louis XIV. A great patron of the arts, Philippe amassed over 500 paintings known as the Orléans Collection which was housed at the Palais-Royal, the seat of Philippe's regency. The Regent's collection included works by painters such as Titian, Raphael, Veronese, and Caravaggio alongside paintings by Peter Paul Rubens (1577-1640), Anthony van Dyck (1599-1641), Philips Wouwermans (1619-1668), and Rembrandt van Rijn (1663-1669). The Palais-Royal was open to the public and served as a place for artists, amateurs, and connoisseurs alike to view the collection. Important for Lancret were the Dutch and Flemish paintings including nineteen paintings by Rubens, ten 
paintings by van Dyck, nine paintings by David Teniers (1610-1690), three by Gerrit Dou (1613-1675), and four by Wouwermans.

In addition to the regent, other major patrons of art helped to shift the tastes from that of a classicized Baroque style to the goût modern. Pierre Crozat (1665-1740) and the Comtesse de Verrue, Jeanne-Baptiste d'Albert de Luynes (1670-1736), were two figures who helped to shape the art market during the early part of the eighteenth century. Their respective collections included numerous Old Masters alongside the works of more modern artists. Rochelle Ziskin has noted that both collectors' Parisian houses were places where artistic discourse was discussed, assembly places for artists and art lovers alike, and "a locus for assessing competing systems of value, where distinctive outlooks were forged, defined, and absorbed." ${ }^{14}$ The importance of Crozat and the Comtesse in helping to define the artistic tastes of the eighteenth century cannot be overlooked. Furthermore, at one time or another, they were both patrons of Watteau and Lancret.

This shift in the Parisian art world continued into the reign of Louis XV when he achieved majority in 1721. Louis XV also moved away from the public life of his greatgrandfather to that of a more private lifestyle, as much as his public position of king allowed. According to popular opinion, the young king was more concerned with his leisure time activities such as hunting than he was with affairs of the state. Louis did enjoy the theatre, dinner parties, and gambling and he left many of the matters of state to Cardinal Fleury, André-Hercule de Fleury (1653 - 1743), who became the minister of State. However, the King met daily with his ministers, drafted letters to foreign

\footnotetext{
${ }^{14}$ Rochelle Ziskin, Sheltering Art: collecting and social identity in early eighteenth-century Paris (University Park, PA: Pennsylvania State University Press, 2012), 2.
} 
dignitaries, read foreign policy documents, and examined accounting books. ${ }^{15}$ The historical misconceptions about Louis' neglect of his kingly duties may have been perpetuated due to his preference for privacy. Louis was apparently shy and preferred the company of a small intimate group. His preference for this more intimate lifestyle was borne out in the Rococo period: comfort and convenience were favored over pomp and stateliness. In the arts, the demand for smaller pictures, as opposed to large-scale history paintings, continued. Despite still being the largest, the crown was no longer the only great patron of the arts.

The French Academy also saw a slight shift from the idealizing classical tradition of French history painting towards that of a more Flemish style. In 1699 artist and theoretician Roger de Piles (1635-1709) advocated the approach of the colorists exemplified by the works of Rubens and, in 1720, Antoine Coypel (1661-1722), the director of the Academy, delivered a speech promoting Northern traditions to be discussed in Chapter Three. Watteau was also a major factor in the shift of the Academy towards accepting new subjects in painting and helping to break down long-standing associations of hierarchy within the arts. In 1717 Watteau was accepted to the Académie with his work, Pèlerinage à l'île de Cythère (figure 1). Watteau's painting confounded the conventions of history painting by depicting a mythological subject with figures in contemporary dress. Initially accepted as a history painting its designator was later changed to "une feste galante" since it did not meet the grand traditions of history painting in scale or contemporary subject. With the submission of Pélerinage, Watteau

\footnotetext{
${ }^{15}$ Oliver Bernier, Louis the Beloved: The Life of Louis XV (New York: Doubleday \& Company, Inc., 1984),
} 66-67. 
and the Academy created a new category in of subjects, the fête galante. As Mary Sheriff has pointed out, with the creation of this title the Académie both upheld "its hierarchy of genres and makes room for a new subject matter." 16 That is not to say that Watteau brought about the destruction of hierarchies in painting with regards to the Académie but rather opened a door to more and different subjects than those that had been traditionally accepted.

Much like Watteau, Lancret's experiences ranged from popular street subjects to the high aristocracy of Parisian society and the official culture of the Royal Academy. This included wealthy collectors and patrons of all social levels. Class distinctions were challenged as the bourgeois middle class gained more wealth and social rank, angering the traditional aristocracy. Lancret, it appears, did not favor one sector of society over another; his collectors ranged from Louis XV and Frederick II (1712-1786), King of Prussia, to Crozat, a wealthy middle-class patron of the arts. Lancret, all the while, continued to produce paintings of idealized social interactions that would have appealed to both aristocrats and the bourgeois who imitated them.

The Salon culture of the Académie had also shifted. During Lancret's time, the academic Salon exhibitions went from varied and not very consistent occurrences to taking place every other year. These exhibitions were public events in which the various levels of society participated. Journals and other publications which either decried or lauded artists and their paintings began to appear more frequently. Indeed, a number of these are discussions in forthcoming chapters used as aids in understanding how a

\footnotetext{
${ }^{16}$ Mary D. Sheriff, "Introduction: The Mystique of Antoine Watteau" in Antoine Watteau: Perspectives on the Artist and the Culture of his time, ed. Mary D. Sheriff (Newark: University of Delaware Press, 2006), 23.
} 
contemporary audience viewed and understood these paintings. This was the birth of the modern art public. As Thomas Crow has argued, the earlier, sporadic public exhibitions, official or not, had allowed the Parisian populace access to a wide-ranging array of artistic production. ${ }^{17}$ As a result the of these shows, the public began to demand more and larger exhibitions, educated themselves about artist, periods, and styles, and started to create a demand for certain types of paintings. Crow notes that "the choices of the patrons found their ratification in the collective assent of the public." ${ }^{18}$ In this sense, the public was also responsible for the relaxation of academic hierarchies in painting. It was into this new and changing cultural milieu that Lancret's paintings were received and upon which the artist intentionally capitalized.

\section{Lancret as an Artist}

Lancret was born in Paris to a working-class family. His father was a coachman and his mother's family were cobblers. His early training as a painter was under Pierre Dulin (1669-1748), a history painter and member of the Académie. Lancret began his apprenticeship under Dulin when he was about seventeen, around 1707; he joined the Académie sometime shortly after. As Holmes notes, one of the only firm dates regarding Lancret's early training are known because of a record stating that he and two other artists were expelled from the Académie on September 28, 1708. They were suspended indefinitely on October $6^{\text {th }}$ of the same year. Lancret and his fellow students were later

\footnotetext{
${ }^{17}$ Crow, Painters and Public Life, 82.

${ }^{18}$ Crow, Painters and Public Life, 86.
} 
readmitted to the Académie on January 5, 1709, and in 1711 Lancret competed for the annual Prix de Rome, which he did not win. ${ }^{19}$

Lancret left Dulin's studio and joined Claude Gillot's (1673-1722) sometime after 1712, as posited by Holmes. ${ }^{20}$ Gillot, Watteau's former teacher, was known for his commedia dell'arte depictions and grotesqueries. Here Holmes's biography differs little from that of Wildenstein's, though she does question some of the assumptions Wildenstein makes about Lancret's early career and training that the elder author puts forth. According to Wildenstein, the shift from the studio of Dulin to Gillot, and from history painting to genre painting was caused "without a doubt" by "the failure we have just described," namely Lancret's loss of the Prix de Rome. ${ }^{21}$ Holmes suggests that the switch was for far more practical reasons, given the popularity of Watteau's works in the early 1710 s. Holmes cites the enthusiasm surrounding numerous paintings that Watteau displayed at the Académie, the rise in popularity of genre paintings among wealthy individuals, and the subsequent decline in the market of history paintings as possible factors that influenced Lancret's switch. The author asserts that this switch assured "a more secure academic and financial future," or that Lancret became Gillot's assistant to simply earn more money. ${ }^{22}$

\footnotetext{
${ }^{19}$ Mary Tavener Holmes, Nicolas Lancret, 1690-1743 (New York: Harry N. Abrams, 1991), 21-22.

${ }^{20}$ Holmes, Nicolas Lancret, 1690-1743, 23 and Georges Wildenstein, Lancret, (Paris: G. Servant, 1924), 45. Holmes notes that scholars disagree on the year in which Lancret joined Gillot. Wildenstein puts the switch from Dulin to Gillot in the year 1711 given the loss of the Prix de Rome while another biographer puts it in the same year as the expulsion from the Académie, 1708. Ballot and Dézallier claim the move was due to the rising polarity of Watteau circa 1712 .

${ }^{21}$ Wildenstein, Lancret, 10 ; « ... sans doute, mais peut-être aussi l'échec que nous venons de relater.»

22 Holmes, Nicolas Lancret, 1690-1743, 23-24.
} 
The suggestion of academic and financial security seems logical given that Lancret went on to receive numerous commissions from the various rulers of Europe and the enormous volume of genre paintings he completed. ${ }^{23}$ The sheer number and variety of paintings made by Lancret confirms Holmes's assertion of academic and financial success as reasons for the shift from history to genre painting. More than simply a means of financial gain, Lancret's shift to genre painting is indicative of the changing social, political, and artistic values of the period.

\section{Lancret's early emulation of Watteau}

It is not known when Lancret and Watteau first crossed paths. Holmes notes that Lancret may have first seen paintings by Watteau at the Académie's 1712 exhibition. ${ }^{24}$ He possibly could have meet the painter then. Wildenstein suggests that the artist met in 1717. ${ }^{25}$ Whatever the date of the artists' first meeting, the first instance of the influence of Watteau on Lancret is described by an anecdote included in Ballot's biography; Watteau supposedly told Lancret he must sketch from nature. Lancret then completed two works and presented them to Watteau who greatly admired them. Lancret was given the status of agréé by the Académie in 1718, presumably based on these paintings. ${ }^{26} \mathrm{He}$ then achieved the status of reçu on March 24, 1719 as a painter of fêtes galantes, the category created for Watteau's reception piece in $1717 .{ }^{27}$ Besides Watteau, Lancret was the only other artist in that decade to be admitted to the Académie under this

\footnotetext{
${ }^{23}$ Holmes, Nicolas Lancret, 1690-1743, 12.

${ }^{24}$ Holmes, Nicolas Lancret, 1690-1743, 22-23.

${ }^{25}$ Wildenstein, Lancret, 11.

${ }^{26}$ Silvain Ballot de Sovot, «Éloge de Lancret, peintre de Roi.» in Éloge de Lancret, peintre de Roi, by J.J. Guiffrey, (Paris: Rapilly, c. 1874), 18.

${ }^{27}$ Wildenstein, Lancret, 45.
} 
designation. ${ }^{28}$ The admittance of Lancret to the Académie with this title is telling, since its first use was only two years previous on the admittance of Watteau. However, the congenial relationship between Lancret and Watteau was short-lived as they argued over some paintings shown by Lancret at the Exposition de la Jeunesse, a free exhibition of paintings in Paris that typically occurred on Corpus Christi day. ${ }^{29}$ Apparently, Watteau was upset that the paintings were so similar to his own, and the relationship between the artists ended. In this instance, Holmes's biography on Lancret does not differ from Wildenstein's as both authors depend on Ballot as their source of information.

As Holmes rightfully notes, it is in Lancret's early works that the stylistic influence of Watteau is clear. She argues that this period of early emulation lasts from 1712 to $1725 .^{30}$ Lancret started to shift away from the stylistic characteristics that linked him to Watteau as early as the 1720 s despite "retaining certain derivative aspects." 31 The stylistic affinity to Watteau can easily be seen in Lancret's presumed 1719 reception piece for the Académie, Gallant Conversation (figure 2), which has close ties to Watteau's own 1717 work, Harlequin and Colombine (Voulez-Vous triompher des Belles?) (figure 3), in both the subject matter and the manner in which it was painted. ${ }^{32}$ Though Lancret's reception piece does not include the figure of Harlequin, one figure could possibly be identified as Pierrot and a number of the other figures appear to be

\footnotetext{
${ }^{28}$ Jean-Baptiste Pater was admitted as a painter of fêtes galantes in 1728, almost a decade after Lancret. ${ }^{29}$ Holmes, Nicolas Lancret: Dance Before a Fountain (Los Angeles: Getty Publications, 2006), 35 and Ballot de Sovot, «Éloge de Lancret, peintre de Roi, » 19. Holmes states the earliest record of Lancret exhibiting works at the exposition is in 1722; however, as she notes and as it is told through Ballot de Sovot, Lancret had to have exhibited works at the annual Exposition de la Jeunesse before Watteau's death in 1721 since Watteau was upset about Lancret's works so closely resembling his own.

${ }^{30}$ Holmes, Nicolas Lancret, 1690-1743, 25, 27.

${ }^{31}$ Holmes, Nicolas Lancret, 1690-1743, 27.

${ }^{32}$ Holmes, Nicolas Lancret: Dance Before a Fountain, 33.
} 
wearing theatrical dress. Additionally, the pose of the central woman in Watteau's painting is copied by Lancret almost exactly. Both paintings depict forested landscapes and include musicians, numerous other figures, and sculpture. In her 2006 book, Dance Before a Fountain, Holmes notes that two characteristics of Lancret's early works are the small heads of his figures and the abundance of figures in his paintings. ${ }^{33}$ The second feature is often characteristic of Watteau's works as well. Watteau's death in July 1721 may mark Lancret's shift away from the elder artist towards a more personal style. By the 1730s, Lancret has developed his own more robust figures with his unique heavily-lidded eyes. Throughout the rest of his career, however, Lancret continued to draw on Watteau's paintings for figure and landscape compositions.

During the 1730s and 1740s Lancret's paintings were widely collected by important patrons in Paris and at foreign courts. A stylistic development during this period helped him achieve a definitive break from Watteau's style: Lancret's figures become larger in relation to the background and fewer in number. ${ }^{34}$ The artist eventually achieved the rank of Conseiller, or councilor, at the Académie in 1735, the highest rank possible for a non-history painter and second only to a director. ${ }^{35}$ As Holmes notes, Lancret's major patron during this period of his production was Louis XV. ${ }^{36}$ Lancret completed paintings depicting the seasons, children's games, portraits, scenes from plays, and other paintings of contemporary life. Prints after his paintings were popular, widely available, and helped to spread the influence of Lancret and genre painting. In 1740

\footnotetext{
${ }^{33}$ Holmes, Nicolas Lancret: Dance Before a Fountain, 38.

${ }^{34}$ Holmes, Nicolas Lancret, 1690-1743, 46.

${ }^{35}$ Holmes, Nicolas Lancret: Dance Before a Fountain, 22.

${ }^{36}$ Holmes, Nicolas Lancret: Dance Before a Fountain, p. 41.
} 
Lancret married Marie Boursalt, and the couple remained childless at Lancret's death three years later. Holmes states that "Lancret died virtually at his easel, on September 14, 1743," reiterating Ballot, after having contracted pneumonia. His final painting, The Peepshow Man, depicts a country fair in a rural setting with the central focus on a Savoyard and his peepshow box. ${ }^{37}$ Interestingly, towards the end of this life Lancret thematically returned to Watteau's paintings. The Peepshow Man (figure 4) is indebted to Watteau's depictions of Savoyards such as La Marmotte (figure 5). Both images depict the wandering performers depicted by numerous artists throughout the eighteenth century and the figures often carry sexual connotations or associations. ${ }^{38}$

The instance of The Peepshow Man offers some insight into the artist's personality. According to Ballot, the version upon which the artist was working when he died included marmots but very closely resembles the surviving painting. The bawdy sexuality of the characters is typical of numerous paintings by Lancret. Paintings such as La Marmotte and The Peepshow Man were often visual representations of risqué puns. For instance, the word marmot was synonymous with female genitalia and the recorder the animal is trained to dance to is a reference to male genitalia. Posner has suggested that Watteau did "not especially appreciate their [the rustic images of performers] content, for he failed to give the scenes the kind of comic air or explicitness that seems needed to communicate the jokes properly." 39 Everything that Watteau's painting lacks, however, Lancret's contains. Whether or not Lancret personally enjoyed these bawdy

\footnotetext{
${ }^{37}$ Holmes, Nicolas Lancret, 1690-1743, 104; Holmes asserts that the The Peepshow Man previously in the collection of Frederick the Great is a variant on this final painting and not the final painting.

${ }^{38}$ See Donald Posner, Antoine Watteau (Ithaca, NY: Cornell University Press, 1984), 27 and Holmes, Nicolas Lancret, 1690-1743, 104.

${ }^{39}$ Posner, Antoine Watteau, 27.
} 
puns and sexual connotations is a matter of debate; yet, Ballot notes in his biography that Lancret's final painting was the only one that ever truly pleased the artist. ${ }^{40}$ Presumably the artist did enjoy these types of images and the sexual innuendo they included. While this question may never be definitively answered, Lancret did capitalize on this type of image throughout his career.

\section{The influence of Watteau and the North}

Paintings such as La Marmotte and The Peepshow Man were based on characters from real life peasant festivals and images of such festivities depicted in the paintings of seventeenth-century Dutch and Flemish artists. Watteau was inspired by Netherlandish paintings of the seventeenth century and his admiration for them was transferred to Lancret. Oliver Banks, among others, has unquestionably shown that Watteau drew heavily on both Flemish and Dutch works of the seventeenth century. ${ }^{41}$ Additionally, since Watteau was from Valenciennes, a town which still considered itself Flemish despite being under the control of France, he may have identified himself as Flemish also.

Certainly, Lancret would have been familiar with seventeenth-century Dutch and Flemish art through his training at the Académie. As Holmes states, Lancret's mature

\footnotetext{
${ }^{40}$ Ballot de Sovot, «Éloge de Lancret, peintre de Roi », 27-28 ; « Il conçut, quelque temps avant sa mort, l'idée d'un tableau qu'il disait vouloir faire pour son plaisir et sa propre jouissance. Le sujet et est un montreur de curiosités place dans un village, accompagne de petites montreuses de marmottes, et entoure de spectateurs. Il se renferma à cet effet sans vouloir voir personne, ce qui donna lieur a deux de ses amis de pénétrer ce mystère, et de voir représenter dans son cabinet une espèce de scène comique, lorsqu'ils le surprirent au milieu d'une troupe de ces marmotines, dont les attitudes grotesques contrastaient si singulièrement avec le sérieux de son pinceau. Parvenus presqu'à la fin de cet ouvrage, il s'avoua pour la première fois de sa vie, content de lui-même, en le regardant. Ce sentiment d'amour-propre, que lui était si étranger, semblait être le signe de sa fin. »

${ }^{41}$ Oliver T. Banks, Watteau and the north: studies in the Dutch and Flemish baroque influence on French rococo painting (New York: Garland Pub., 1977).
} 
works depict a "robust naturalism that distinguished it from the more delicate images of the mature Watteau or Pater...a naturalism akin to that of early Watteau and to seventeenth-century Flemish painting." 42 Clearly Lancret was also influenced by Northern paintings, as he depicted village wedding scenes such as Le Repas de Noce au Village and The Wedding Breakfast (figures 6 and 7) and other images of outdoor dining parties. The subject matter of these paintings is based on the works of Flemish and Dutch painters, like David Teniers and Esaias Van de Velde (1587-1630), and this connection is further investigated in Chapter Two.

Lancret was influenced by Watteau and learned some subject matter from the elder artist's oeuvre; nevertheless, Lancret also looked past Watteau's work to the Northern paintings that inspired them. While Watteau was most concerned with the aspects of the fête he found in paintings such as Teniers', Lancret was more concerned with the dining aspects found in the same paintings. It was this emphasis on dining and Lancret's ability to fuse iconography with contemporary society that set Lancret apart from Watteau.

Since this dissertation focuses mainly on Lancret's depictions of food and dining, the ways in which Lancret differed from Watteau in the depiction of foodstuffs and the acts of dining or cooking are of primary interest. It appears as though Lancret, while utilizing similar subject matter and borrowing compositions from Watteau, imbued his paintings with details of food items that furthered their narratives. This is opposed to Watteau, who included food items as minor details in allegorical or metaphorical

\footnotetext{
${ }^{42}$ Holmes, Nicolas Lancret, 1690-1743, 104.
} 
references to mythology and traditions of genre painting. Additionally, since this dissertation is also concerned with the aristocratic traditions of the hunt, depictions by both artists of this topic stand to further articulate the ways in which Lancret varied the subject matter he inherited from Watteau.

\section{Food in Rococo Paintings}

The earliest instance of Watteau's depicting a meal is in the painting, Le repas de campagne (figure 8), which unfortunately has been lost. It exists only through an engraving after the original. Donald Posner contends that its attribution is unquestionable given that the original was in Jean de Jullienne's (1686-1766) collection when the print was made. Jullienne was a major collector of Watteau's work and the driving force behind the posthumous engraving of Watteau's oeuvre. Le repas de campagne depicts a humble country scene of a woman holding an infant while an old man fills her cup; an adolescent boy stands holding a bowl and blowing on the food on his spoon to cool it down. A younger boy kneels in front of the table allowing the dog to lick his plate. Posner dates this work to Watteau's pre-Paris career before 1705 or possibly as late as 1712. This work echoes traditions of Netherlandish paintings in the depiction of rustic and rural country scenes. Posner claims that unlike the seventeenth-century paintings on which this work is based, Watteau shows his figures as neat and clean despite the realities of rural life. ${ }^{43}$ Posner cites two other paintings as falling into this same period of Watteau's work, and both show Northern influences on his painting: La Cuisinière (The cook) (figure 9) and Retour de guinguette (Return from the Tavern) (figure 10). There is

\footnotetext{
${ }^{43}$ Posner, Antoine Watteau, 15-18.
} 
some confusion surrounding the first image's attribution to Watteau; as Posner notes, it has been contested since $1929 .^{44}$ The painting is of a woman who appears to be cleaning copper pots outside of a humble dwelling. Banks has convincingly argued that this painting should be attributed to Watteau and more recently Pierre Rosenberg has echoed his conclusion. ${ }^{45}$

Possibly following the influence of Watteau, Lancret also painted a number of scenes of women doing domestic chores or occupying a domestic interior, including $L a$ Chercheuse de Puces (figure 11), La Cuisine (figure 12) Kitchen Interior (figure 13), Le Nègre et La Cuisinière (figure 14), and Le Galant Valet (figure 15).These images are all reminiscent of Northern works by artists such as Teniers, Dou, or even Joachim Beuckelaer's (ca. 1533-1574) voluptuous female vendors with regard to La Cuisine. The position of the female figure inspecting a dead hare at the left of La Cuisine is almost identical to the woman in Dou's painting, A Poulterer's Shop (figure 16). The woman shirking the advances of the male figure in Le Galant Valet is different from the complicity of the women in Northern kitchen scenes such as Beuckelaer's Market Scene (figure 17), but the amorous undertones remain.

Returning to Watteau's early depictions of dining, the attribution of Retour de guinguette (figure 10) to the artist's oeuvre has not been questioned. This image depicts a group of figures lined out across the horizon from the left foreground to the center and another group of figures to the right in the middle ground seated at a dining table. The

\footnotetext{
${ }^{44}$ Posner, Antoine Watteau, 18; Margaret Morgan Grasselli and Pierre Rosenberg with the assistance of Nicole Parmantier, Watteau: 1684-1721 (Washington: National Gallery of Art, 1984), 256.

${ }^{45}$ Banks, Watteau and the north, 118-122; Grasselli, Rosenberg, and Parmantier, Watteau: 1684-1721, 256-7.
} 
group seems to be in the middle of a meal, with one course having been removed and another about to be served. In the right foreground a pair of hunters relaxes against a tree with their dogs. The subject of the painting could be said to be the juxtaposition of the polite society of the diners to the right with the group of coarser drunks in the central foreground. In these paintings, Watteau is continuing the tradition of Northern genre paintings and scenes of country life in the vein of Teniers. With the exception of Retour de guinguette, Watteau's paintings Le repas de campagne and La Cuisinière depict the idealization of rural life that would blossom later in the century in the works of other artists such as François Boucher (1703-1770). ${ }^{46}$ The focus of the paintings by Watteau, and later Boucher, is not on the food being consumed or the act of dining but rather the happy bucolic life as imagined by the artist and idealized by French society.

Some of the other earliest instances of Watteau including food items, or rather references to cooking and eating, are in his paintings of military scenes. These works have been studied by art historian Julie-Anne Plax, who contends that, as with his other works, Watteau's military works can be seen as “confounding, inverting, and toying ironically with preexisting painting genres, conventions, traditions, and practices." ${ }^{47}$ These military subjects date from Watteau's early career, around 1709-14. Not only do they display the continued influence of Northern artists on Watteau's oeuvre, they frequently depict men, and sometimes women, in the act of cooking as part of the nonheroic aspects of military life. Additionally, as Plax has noted, in a few instances the men

\footnotetext{
${ }^{46}$ Posner, Antoine Watteau, 15-18.

${ }^{47}$ Julie Ann Plax, Watteau and the Cultural Politics of Eighteenth-Century France (New York: Cambridge University Press, 2000), 53.
} 
are shown near a buvette, or a refreshment tent. ${ }^{48}$ These paintings of military life were attractive to city dwellers because they portrayed the romanticized notions of the lively, unrestrained, adventurous lifestyle of the soldiers - what Posner has equated to a more modern-day romanticization of cowboys and the American West. ${ }^{49}$ Aaron Wile notes that unlike their Dutch and Flemish predecessors, Watteau's paintings depict "an intimate vision of war, where the human element takes precedence." ${ }^{50}$ The act of dining or the food being prepared is not the central focus of the works but simply a mundane task carried out in the representation of the real-life circumstances of the military camp.

Similar to Retour de guinguette but based on military life is the painting, Biovac (Camp Volant) (figure 18). In this work Watteau depicts a man tending a fire over which a large pot hangs. This same pot, and a person tending it, is depicted in Watteau's other paintings The Halt (Alte) and Halt of a Detachment (Détachement faisant alte). Regardless of where the pot and the accompanying person are depicted within the composition, it is an extraneous detail that is not necessarily needed to further the narrative of the paintings. Though in one military scene by Watteau, The Respite from War (Les délassements de la guerre) (figure 19), the artist depicts his figures seated around a makeshift table. Whether or not they are eating is debatable, though there does not appear to be any evidence of food included in the work. Additionally, the title of the work in no way indicates that the subject matter of this work is a meal but simply a break or a rest from battle. Another painting, entitled Départ de garnison (Depart of the

\footnotetext{
${ }^{48}$ Plax, Watteau and the Cultural Politics of Eighteenth-Century France, 57.

${ }^{49}$ Posner, Antoine Watteau, 31.

${ }^{50}$ Aaron Wile, Watteau's Soldiers: Scenes of Military Life in Eighteenth-Century France (New York: The Frick Collection, 2016), 15.
} 
Garrison) (figure 20), depicts a table underneath a tree with a cloth draped over a tree limb, creating a make-shift tent. Here, as with the diners in Retour de guinguette, the table is relegated to the side of the composition with the main subject of the work displayed in the center.

Lancret rarely produced paintings of military life. A work from 1722, titled Military Camp (figure 21), is his only known surviving painting on the subject. It depicts a camp with tents, soldiers, officers, and a lady but does not include a firepit, cooking pot, or other evidence of food. ${ }^{51}$ However, another painting by the artist depicts a group crowded around a fire that is similar to the cooking pot and its tender in Watteau's works. While Lancret does not specifically include a pot, the fire is evident and numerous figures crowd around it in the right foreground. This figural grouping from the painting Fête in a Wood (figure 22) appears as though it could have been taken straight out of one of Watteau's military paintings. The figures, barrels, servants, horse, and tent would be more natural in a painting of military life than in an elegant party in the forest. Given the title of the painting, it is interesting that Lancret would choose to represent the more mundane aspect of the logistics of such a party in the right foreground as opposed to the subject matter of the painting featured in the middle ground and background. While Watteau focused on the mundane aspects of life as a soldier, Lancret depicted the mundane aspects of a fête. In this instance Watteau's images of military life provide details that enhance the already established subject matter as opposed to complicating it

${ }^{51}$ Wile, Watteau's Soldiers, 62, Figure 33. 
as Lancret's painting does. The ways in which Lancret complicated the compositions and subject matter he borrowed from Watteau warrants further investigation.

Lancret was influenced by Watteau's work and often borrowed compositions and subject matter; however, Lancret imbued his images with multilayered meanings that further the narrative message of his paintings in ways different than his one-time friend. The iconography of various foodstuffs helps to distinguish Lancret's works from the ambiguity of many of Watteau's paintings. The earliest comparable example of this is seen in Lancret's work L'automne (figure 23), which is one of a four-part series of paintings depicting the seasons. As with scenes of kitchen women and military life, the depictions of the seasons are another genre that has its roots in the Northern tradition of painting that allowed Lancret to set himself apart from Watteau.

\section{The Marquis de La Faye's Series of the Seasons}

In L'automne Lancret directly quotes Watteau's earlier painting Les fêtes vénitiennes (figure 24). Both scenes depict numerous people occupying a clearing surrounded by a forest with a semi-circular architectural wall, a fountain, and a central couple who appear to be dancing. The other figures are gathered to the right of the composition and include musicians and figures from the theatre. Watteau included a fool behind the hurdy-gurdy player at the right, while Lancret replaced the hurdy-gurdy with a violoncello and the fool with Harlequin - both shown to the left of the table. The table is unique to Lancret's painting and is being laid with baskets of grapes. While Lancret borrows the composition of Watteau's painting, he takes a seemingly ambiguous painting and imbues it with the Northern tradition of representing the seasons by including 
numerous baskets of grapes or fruit-laden vines throughout the painting. Therefore, the grapes that serve as the indicator of autumn become the single detail around which the entire narrative aspect of the painting is focused despite the copying of Watteau's earlier painting.

As opposed to Lancret's series of the seasons based in genre subjects, Watteau followed the traditional mythical and allegorical representations of the seasons; he used the motif of the seasons in at least one known series that depicts the usual foodstuff associated with the season when they are harvested. ${ }^{52}$ This series has been dated by scholars to 1716 and commissioned by Crozat for his dining room. ${ }^{53}$ The Spring painting (Le Printemps) (figure 25) was destroyed by a fire in 1966 and is known only through a photograph and engravings. ${ }^{54}$ It does not contain any food items, just flowers. Spring is represented by two figures, a female figure, presumably Flora, sitting on a billowing cloud being crowned by the winged male figure of Zephyr. It also originally included a ram; a bull; and presumably a set of twins, the zodiac signs for spring: Aries, Taurus, and Gemini; which can be seen in the print after the original but were later removed from the final version of the painting (figure 26). ${ }^{55}$

The allegorical figure of Summer (L'Été) (figure 27), identifiable as Ceres or Demeter, the goddess of agriculture and grain crops, is depicted sitting on a cloud,

\footnotetext{
52 In addition, Graselli's book on Watteau identifies at least eight paintings and drawings that depict one or more of the seasons, identifying at least 5 various series. Each of these works appears to draw on the mythological and allegorical conventions associated with this particular genre.

${ }^{53}$ See Grasselli, Rosenberg, and Parmantier, Watteau: 1684-1721, 325-326 and Posner Antoine Watteau, 76-79. Also see Ziskin, Sheltering Art, 84-85, 87-91.

${ }^{54}$ Grasselli, Rosenberg, and Parmantier, Watteau: 1684-1721, 328.

${ }^{55}$ See Posner Antoine Watteau, pl. 15, 95-97 and Grasselli, Rosenberg, and Parmantier, Watteau: 1684$1721,328$.
} 
reclining on a lion, and holding a sickle. Another female figure and a putto are at her left side holding sheaths of wheat. An additional sheath of wheat appears at the goddess' right side, more is included in her crown, and a lobster appears to the left of the image. The lion indicates the zodiac sign for Leo which takes place from July to August, while the lobster is a sign of resurrection or rebirth since it sloughs and replaces its shell every year. ${ }^{56}$ The lobster could also be a confusion of the zodiac sign for Cancer normally indicated by a crab, and the woman to Ceres' side could be Virgo since this zodiac sign is often represented by a female figure holding wheat.

Watteau's allegory for Autumn (L'automne) (figure 28) depicts a reclining man having his cup filled by a satyr, a putto leaning on his leg, and a female admirer reclining in front. The male figure is identifiable as Bacchus or Dionysus through the god's association of wine and the leopard or cheetah pelt that is draped on his lap and lays at his side. An earlier sketch for the painting is compositionally more related to Summer as it depicts a single central female figure surrounded by grapes, melons, apples, and peaches (figure 29). A small putto at her side holds a white cloth laden with more fruit. While the grapes are not explicitly shown in the final version of the painting, the figure of Bacchus or Dionysus is a known allegory for Autumn since the grape harvest in France typically takes place in September. Interestingly, neither the sketch nor the final composition includes the accompanying zodiac images of Libra, Scorpio, or Sagittarius. It seems that a Bacchanalian image was enough of the viewers to identify the work as Autumn.

\footnotetext{
${ }^{56}$ Silvia Malaguzzi, Food and feasting in art, trans. Brian Phillips, (Los Angeles: J. Paul Getty Museum,
} 2008), 77-178. 
Finally, the allegory of Winter (L'hiver) (figure 30) depicts a male figure, possibly Old Man Winter, huddled before a small fire and another male figure carrying fodder for the fire. Capricorn, Aquarius, and Pisces are all depicted in this image: Capricorn is the goat in the upper right, Aquarius is the figure pouring water to the right, and Pisces is shown below in the form of two fish. Watteau also included winged figures, the eldest of whom is depicted with a beard and could be said to represent Boreas, embodiment of winter and the North Wind. The other figures are presumably lesser Winds; as noted above, Zephyr, the Spring Wind, appears in the Spring panel. ${ }^{57}$

Even though Watteau's painting of Autumn does not depict grapes, the figure of Bacchus identifies the season due to its connection to the grape harvest. However, Watteau did paint another work that contains grapes, Le Lorgneur (figure 31). Like many of Watteau's paintings, this work has been lost and survives only through an engraving. Posner claims that the grapes in Le Lorgneur symbolize the "amorous pleasure to be taken. ${ }^{, 58}$ Since grapes symbolize earthly pleasure, the association of the amorous pursuits of the male figure and the fact that he is holding a rather phallic musical instrument with the grapes leaves the viewer wondering if the female figure will be enticed by the man's efforts. In this way, the grapes reinforce the title of the painting and the amorous intention of the man, though their inclusion is not necessary to identify the subject matter of the painting.

Additionally, Watteau completed another painting based on the theatre in which wine and grapes are shown. L'amour au théâtre françois (Love in the French Theatre)

\footnotetext{
${ }^{57}$ The final version of L'automne and L'hiver are only known through engravings. See Posner, Antoine Watteau, 79 or Grasselli, Rosenberg, and Parmantier, Watteau: 1684-1721, 325-328.

${ }^{58}$ Posner, Antoine Watteau, 154.
} 
(figure 32) depicts a scene from the comic opera Festes de l'Amour et de Bacchus in which the central figures, identified as Bacchus and Cupid, resolve their issues and toast each other. ${ }^{59}$ In this instance, the grapes and wine are needed to further the identification of the central figure as Bacchus, as is the animal skin draped around his neck, since the figure is dressed in a theatre costume. In a similar manner, the sheath of arrows is needed to identify the other figure as Cupid. The main subject of the painting is the scene from a play and the theatre, as opposed to mythology and the work is another instance of grapes and wine aiding in the allegorical reference to a mythic figure.

Watteau also composed a number of series of arabesques depicting the seasons. These designs were never realized and are only known through unfinished drawings engraved by Gabriel Huquier (1695-1772). The first of these, which represents Autumn (figure 33), shows a man and woman toasting with wine glasses in a way similar to Bacchus and Cupid in L'amour au théâtre françois. ${ }^{60}$ In this work, the woman is reclining on the ground while the man stands beside her. The surrounding frame depicts trees and foliage entangling the arbor-like architecture of the frame. Two herms stand to either side as the vertical edges of the frame; presumably the herm on the left represents Bacchus since the figure appears to wear a crown made from a grape vine. The second representation of Autumn (figure 34) does not depict grapes but rather the harvesting of the grapes. The frame of a third unfinished drawing (figure 35) is composed of a "raffiawrapped wine bottle... trailing vine leaves, and a satyr's head." ${ }^{\prime 61}$ These elements are in line with Watteau's usual inclusion of mythological representations of the season. This

\footnotetext{
${ }^{59}$ Grasselli, Rosenberg, and Parmantier, Watteau: 1684-1721, 338

${ }^{60}$ Grasselli, Rosenberg, and Parmantier, Watteau: 1684-1721, 81.

${ }^{61}$ Grasselli, Rosenberg, and Parmantier, Watteau: 1684-1721, 105-6.
} 
partial drawing could also be said to be in the vein of the Northern tradition of depicting the seasons in which images of the harvest are often present. ${ }^{62}$

Unlike Watteau, Lancret uses the grapes as the sole means to identify the scene as that of the Autumn season. They are needed to do so since he stripped his painting of all allegorical or mythological references to classical antiquity. The grapes in Watteau's Le Lorgneur are not needed to forward the narrative, they are extraneous detail, while the grapes in Lancret's L'automne are central to the identification of the scene as that of Autumn since it lacks all other iconographical or allegorical imagery to support its recognition as such. By including this seemingly innocuous detail, Lancret's painting combines still life with a composition borrowed from Watteau and depictions of the theatre.

This combination of "details that surreptitiously explain" with contemporary life situated in a Watteau-like fête galante and the exclusion of allegory is followed throughout the rest of the images of the seasons. ${ }^{63}$ In the Spring (figure 36) painting Lancret depicts a Watteau-esque scene of male and female figures occupying a clearing surrounded by a forested landscape. The amorous nature of the scene is reinforced through the inclusion of a birdcage and a small, tethered bird held by one of the young women. Besides the amorous nature of the bird and its cage, the only other indicator that this scene is meant to depict Spring is the inclusion of a basket of flowers held by one of the other female companions; the basket of flowers has obvious links to the now lost

\footnotetext{
62 The representation of September in the Duke de Berry's Très Riches Heures (c.1412-16) depicts a grape harvest.

${ }^{63}$ Colin B. Bailey, ““"Details that surreptitiously explain”: Boucher as a Genre Painter” in Rethinking

Boucher, ed. Melissa Hyde and Mark Ledbury (Los Angeles: Getty Publications, 2009), 39-60.
} 
painting by Watteau. The other paintings in the series, Summer (figure 37) and Winter (figure 38), simply show the imagined social activities that might take place during each season and furthers the genre-based nature of the series. Summer depicts a group of women bathing, while Winter depicts a group of women in an interior setting presumably playing the card game piquet. ${ }^{64}$ The Hermitage Museum, which currently owns both the Spring and Summer paintings, erroneously dates the works to around the 1730s.

Fortunately, the Winter painting recently appeared at Sotheby's for sale, as the work was previously only known through engravings. ${ }^{65}$ The Autumn painting, previously in collection of the Homeland Foundation in New York state, is more accurately dated to the years 1721 to 1723 , given the direct borrowing of Watteau's composition and the depiction of the figures. ${ }^{66}$

Lancret's series of the seasons was commissioned by Jean-François Lériget, Marquis de La Faye (1674-1731) and while the exact date of the commission is not known, the paintings appeared in a posthumous sale of Lériget's dated September 29, 1731, placing them firmly in Lancret's early production. ${ }^{67}$ Lancret's biographer Ballot discusses this commission directly after Lancret's altercation with Watteau at the Exposition de la Jeunesse. If Ballot's timeline is correct, the date of the commission for this series occurred just before Lancret's admission into the Académie in 1719. Holmes rightfully notes the commission as "one of the most significant... of Lancret's career,

\footnotetext{
${ }^{64}$ Wildenstein, Lancret, 71.

${ }^{65}$ Holmes claims this painting may actually survive in a private Parisian collection. See Holmes, Nicolas Lancret, 1690-1743, 153, Plate 10, note 2.

${ }^{66}$ Holmes, Nicolas Lancret, 1690-1743, 27; Additionally, Lancret depicted another series of the seasons for Louis XV at the chateau of La Muette which will be further discussed in a later chapter. A third set known only through engravings appears to combine motifs from the other two series, again depicting grapes as the identifier for Autumn. See Wildenstein, Lancret, pl. 6-9, 10-13, and 14-17.

${ }^{67}$ Holmes, Nicolas Lancret, 1690-1743, 70 and Ballot de Sovot, Éloge de Lancret, peintre du Roi, 19.
} 
owing both to the importance of his patron and to the success of his results." ${ }^{68}$ Lériget had been a member of Louis XIV's court, was a diplomat, a military man, wealthy landowner, director of the French East India Company, and art collector. His poetry earned him membership in the Académie Française. The much-repeated story of Lériget's reaction to the first two paintings by Lancret speaks to the artist's talent and ability to capture cultural attitudes in paintings, "When Monsieur Lancret brought the second painting to M. de la Faye, M. de la Faye was so touched by his progress, that he broke the first contract, and gave him double the price of which they had agreed. Would a Medici have done more?"69 Ballot states that the paintings hung in Lériget's salon where they were on view to the numerous art lovers and men of letters not to mention the numerous artists he supported who frequented Lériget's home.

The house owned by Lériget was purchased in 1717 on the rue de Sèvres in the "Croix-Rouge" quarter of Saint-Thomas d'Aquin in the Faubourg Saint-Germain on the Left Bank in Paris. In 1719, the Marquis purchased a second house on the rue du Cherche-Midi, which abutted his first, and a third house also facing the rue de Sèvres. The three houses were combined to create a large hôtel. ${ }^{70}$ Lancret's paintings were set into the wall panels of the salon; two other landscapes and two mythological scenes were also hung in the room. Ziskin has postulated that the mythological scenes may have been copies of Leda and Io by Correggio, two paintings depicting the seductive and deceitful nature of Zeus. ${ }^{71}$ The combination of Lancret's series of the seasons with two

\footnotetext{
${ }^{68}$ Holmes, Nicolas Lancret, 1690-1743, 70.

${ }^{69}$ Ballot de Sovot, Éloge de Lancret, peintre du Roi, 20 ; «Lorsque M. Lancret fut porter à M. de la Faye le second tableau, M. de la Faye fut si touché de son progrès, qu'il rompit le premier marché fait, et lui donna le double du prix dont ils étoient convenus. Un Médicis en eût-il fait davantage? »

70 Ziskin, Sheltering Art, 97-99.

${ }^{71}$ Ziskin, Sheltering Art, 101-102.
} 
mythological depictions of the amorous pursuits of Zeus reinforces the sensual nature of Lancret's paintings.

In addition to this suite of paintings by Lancret, Lériget owned one of the artist's many depictions of the dancer Mademoiselle de Carmargo, one of Lancret's most lauded paintings. ${ }^{72}$ In this salon Lancret would presumably have seen the other paintings accompanying his own - village fêtes of the Northern style by Teniers and one by Watteau, in addition to a painting by Lancret's friend François Lemoyne (1688-1737). Lancret's paintings of the seasons were displayed alongside works by Wouwermans, Rembrandt, Annibale Carracci (1560-1609), Rubens, Joseph Parrocel (1646-1704), and a great many other Northern and French artists. ${ }^{73}$ Lancret's works should therefore be seen as complements to the many Northern paintings in Lériget's collection.

In 1719 Lériget also bought the Château de Condé in the Champagne region just northeast of Paris. Watteau and Lancret both received commissions for the redecoration of the château, along with other artists such as Boucher, Jean-Baptist Oudry (1686-1755), and Lemoyne. ${ }^{74}$ Lemoyne was one of two other artists along with Lancret who had been temporarily expelled from the academy in 1708; he was a great friend of Lancret's who was greatly influenced by both Watteau and Lancret. While the château has undergone some renovations, and is open to the public, little work has gone into distinguishing the works of Lancret from those of Watteau. The chambre de Musicien includes a painting attributed to Watteau (figure 39) over the fireplace, and above the chambre d'Olympe's

\footnotetext{
72 Ziskin, Sheltering Art, 102.

73 Ziskin, Sheltering Art, 102-103, 247-249.

74 « Château Condé, La Château des Princes de Condé, Bourbon-Soissons, et de Savoie, » Château Condé, accessed Feb. 4, 2018, https://www.chateaudeconde.fr/
} 
mantel is a painting purportedly by Lancret (figure 40). In the room labelled chambre de chasseur is a painting of a hunting party by Watteau and an overdoor possibly by Lancret (figure 41 and 42). A final room, l'atelier de Watteau et de ses éleves, depicts views of the surrounding landscape partially painted by Watteau (figure 43) and allegorical overdoors by three other artists. ${ }^{75}$

The painting in la chambre d'Olympe depicts a licentious scene from La Fontaine's fables, a series of Eastern and Western fables published in French verse, but its attribution to Lancret is doubtful. Presuming that the work was completed in 1719 or shortly after, it does not resemble Lancret's developing style seen in such paintings as Gallant Conversation (figure 2) which dates to the same period. The face of the woman especially does not conform to Lancret's type. However, the painting attributed to Watteau in the music room is almost identical to Lancret's L'automne (figure 23) which forms a part of Lériget's series of the seasons. It seems more likely that this painting was by Lancret since the figural style, particularly the head of the woman, her neck, and her bodily proportions are more characteristic of Lancret than Watteau. The contorted pose of the dancing man holding a rattan-wrapped wine bottle is exactly the same in both works and is a pose for which Lancret is known. The reclining figures from the overdoor of the chambre de chasseur are echoed in Lancret's work L'automne. Lériget's commissions for the decoration of the Château de Condé may have been the Marquis' first patronage of Lancret and the first and only time Watteau and Lancret worked together. It is unclear if the commissions for the château's decorations came before or after the Parisian hôtel.

\footnotetext{
${ }^{75}$ Château de Condé - Demeure des Princes. n.d. Visitors Guide. Unpublished.
} 
In addition to the series of the seasons commissioned by Lériget, Lancret completed a four-part series of the elements during the first half of his career commissioned by another marquis, Jacques-Louis de Beringhen, de Châteauneuf (16801723). In the painting representing Earth, La Terre (figure 44), a group of figures occupy a Watteau-esque landscape surrounded by trees and architectural elements. A man stands on a ladder picking peaches from a tree and a woman stands with her skirts bunched in her hands, ready to catch the fruit the man tosses down. A group of women are seated in the foreground and surrounded by various fruits including peaches, pears, grapes, and melons. Similarly, the representation of Water, $L^{\prime} E a u$ (figure 45), depicts a group of figures fishing with a net. Their catch can be seen in the foreground, and a young man slips a fish into the upraised skirt of a standing girl. In both instances the foodstuff depicted furthers the theme and narrative of the painting and reinforces the subject matter. Without these food items, these paintings would be simple pastoral genre scenes; the details are needed to aid in the identification of the subject matter depicted as the foodstuffs are products of the represented elements.

\section{Scenes of dining}

From the initial representation of foodstuff as important iconographic staffage in Lancret's seasons and elements series, the artist shifted toward food items as the subject of his paintings. These scenes of dining inherently imply the consumption of comestibles even if the action of consuming the item is not explicit. However, the foodstuff retained the iconographic associations or connotations that they previously had. 
Presumably the first dining scene that Lancret depicted was painted in 1725 . It was documented in the salon catalogue in the Mercure de France and the entry on Lancret states that he showed a work depicting the "return from the hunt, 4 feet wide by 3, in which we see various horsemen and ladies in riding dress taking a meal." ${ }^{76}$ Recent scholarship by Holmes now suggests that the painting shown was Le repas au retour de chasse (figure 46), now in the Louvre. ${ }^{77}$ The dining aspect of this painting will be specifically discussed in the Chapter Four; what is important for the current discussion is the ways in which Le repas au retour de chasse is still reliant on compositional and figural elements derived from Watteau's paintings. Specifically, the reclining figures are reminiscent of paintings by Watteau, as is the use of the tree line to screen the middle ground with openings allowing a glimpse into the distant background.

Reclining figures, such as the man in tan seated on the ground at the left of Lancret's Le repas au retour de chasse, abound in paintings by Watteau. Works by the elder artist, such as Le bal champêtre (figure 47) and Les plaisirs du bal (figure 48), depict male and female figures seated on the ground in various positions of repose. While Lancret's figure style is still fairly dependent on Watteau in this work, Lancret depicts his figures larger in relation to the pictorial space than the elder artist. Additionally, the figures in Lancret's painting do not have the same waifish appearance of those by Watteau. Both of these aspects are indicative of Lancret's shift to a more mature style.

\footnotetext{
${ }^{76}$ Georges Wildenstein, Le Salon de 1725 (Paris : Les Beaux-Arts), 46 ; « Retour de chasse, de 4 pieds de large sur 3, où l'on voit divers cavaliers et des Dames en Amazones qui font collation. »

${ }^{77}$ Holmes, Nicolas Lancret, 1690-1743, 40-41; Holmes notes that the painting mentioned in the Salon description has not been positively identified but referenced the painting Le déjeuner dans la foret in Sansouci as having a similar subject matter. Both paintings seem to fit the mentioned dimensions at roughly $4.3 \times 2.73$ feet. For more of a discussion regarding the new identification of this painting as the one in the 1725 Salon see Chapter Four.
} 
In addition to the figures, other compositional features of the work echo those of Watteau's paintings. Lancret has included a screen of trees to the left of the image with a large fountain just to the right of the center. The right-hand side of the painting is left open for a deep view into the landscape behind the party. This same compositional feature can be seen in numerous paintings by Watteau, including the previously mentioned Le bal champêtre and Les plaisirs du bal. Additionally, a mirrored composition in which the tree line gaps at the left side of the composition can be seen in the painting The Respite from War (figure 19) and a central gap in the tree line appears in the painting Rendez-vous de Chasse (figure 49). Similar to these paintings by Watteau, Lancret also depicts his figures as occupying the foreground of the painting, though there is less of a gap between the edge of the painting and the figures than Watteau depicted. Lancret seems to have tilted the picture plane at more of an oblique angle than did Watteau.

While Le repas au retour de chasse depicts a meal taken during the hunt, both Watteau and Lancret depicted various aspects of the aristocratic tradition of the hunt on numerous occasions. One of Watteau's earliest depictions of this subject survives only in an engraved copy entitled Retour de chasse (figure 50). In this work, Watteau depicted a single huntress wearing an appropriate hunting costume accompanied by dead game and hunting dogs. ${ }^{78}$ It has been suggested that this painting is a portrait given that the sitter is directly engaging the viewer rather than averting her gaze. Posner postulated that this work was meant to depict Marie-Louise Sirois (1698-1725), the daughter of Watteau's first art dealer and later wife of Edmé-François Gersaint (1694-1750). Posner cites this

\footnotetext{
${ }^{78}$ See Posner, Antoine Watteau, 247, Figure 178.
} 
work as depicting a bourgeois woman whose family aspired to be aristocratic, an interpretation commensurate with Gersaint's social standing. ${ }^{79}$ Additionally, a drawing by Watteau depicts a man and a woman in a forested setting. The woman is seated against a tree, with the man behind her with the leashes of five hunting dogs in one hand and a gun in the other; this drawing is aptly titled Huntress with Dogs (figure 51). In this image Watteau depicts the woman in profile in a simple a genre scene showing the woman's participation in the aristocratic pastime.

Lancret painted two similar works depicting the hunt; however, the subjects of these paintings are men. The first of the two paintings, Halte de Chasseurs (figure 52), is undated and appears in Wildenstein's monograph on the artist. ${ }^{80}$ This work does not have the portrait-like quality of Watteau's Retour de chasse because the central figure has his attention on the hunting dogs surrounding him. He appears to be tempting them with one of the trophies from the hunt. Additionally, another figure, presumably a servant, stands to the right with two more dogs still on leashes. The second of the two paintings, $A$ Hunter and His Servant (figure 53), appears in Holmes's book on the artist and is presumably a portrait given the stance of the central figure and the fact that his facial features do not conform to Lancret's typical style, apart from the heavily lidded, enlarged eyes. $^{81}$

The constant between these paintings of hunters by Watteau and Lancret is the tree in front against which the main figure is seated. In both Watteau's Retour de chasse

\footnotetext{
${ }^{79}$ Posner, Antoine Watteau, 247.

${ }^{80}$ See Wildenstein, Lancret, 99, figure 109; this work is presumably the Swiss-owned painting mentioned by Holmes, Nicolas Lancret, 1690-1743, 88.

${ }^{81}$ Holmes, Nicolas Lancret, 1690-1743, 88.
} 
and Lancret's Halte de Chasseurs, the tree appears on the left side of the canvas with the right open to the distant landscape, and the servant in Lancret's work. Watteau's drawing, Huntress with Dogs, is very similar but is simply reversed. The woman, the tree, and the man are all located at the right of the drawing with the left open to the presumed distant landscape. A Hunter and His Servant, the possible portrait by Lancret, includes the tree in the center of the composition with the sitter slightly to the left and the servant behind him. Again, the right side of the canvas is open to the landscape, though in this instance trees and bushes inhibit a distant view. These four works follow conventional compositional techniques of hunting portraits. The formal similarities do not mean that Lancret was borrowing compositions from Watteau but that both artists were aware of and followed traditional modes of representation when it came to this subject matter.

\section{Paintings of the Hunt}

Other than the hunt portrait or genre scene of the lone hunter, another traditional representation of the hunt is that of a large hunting party. The earliest instance of a painting of this type by Lancret is the painting La fin de chasse (figure 54), completed about 1725. Scholars have often discussed this painting in conjunction with Watteau's better-known work, Rendez-vous de Chasse (figure 49) which was completed only four years earlier. As Posner notes, Watteau's Rendez-vous does not show the party hunting, but rather keeps the action of the painting ambiguous. ${ }^{82}$ Watteau includes the various accoutrements of the hunt, as dead game hung from a gnarled bush can be seen in the left foreground, three men carry guns, and five hunting dogs are seated among the party.

\footnotetext{
${ }^{82}$ Posner, Antoine Watteau, 199-200.
} 
However, the women are not dressed in hunting costume, instead they wear long gowns. These are all indications of the perceived or imagined act of hunting that takes place outside of the painting, activities that these women did not participate in. Posner states that "the main hunting episode becomes an aesthetic conceit in the fanciful park into which the people of Watteau's picture have wandered." ${ }^{\prime 83}$

When comparing Rendez-vous de Chasse work to Lancret's La fin de chasse it becomes evident that the younger artist initially followed Watteau's example but varied the theme to fit his purposes. As with Watteau's work, the hunt has taken place outside of the painting and only the dead stag, the dogs, and the gun indicate the subject of the painting instead of depicting the actions of the hunt. However, Lancret's composition is strikingly different than Watteau's: Lancret abandons the wide view of the park-like setting for one in which the figures are larger and occupy the majority of the foreground. The standing woman and the two horsemen to her right deny the viewer a clear glimpse into the background. Unlike the women depicted by Watteau, however, the standing woman in Lancret's painting wears a bodice fashioned to look like a hunting jacket, but her heels and those of the seated woman wearing a robe volante are not conducive to hunting. Interestingly, both of these women are gesturing towards the seated man. It has been suggested that this painting depicts the family of Lancret, so perhaps the two women are pointing to the artist himself. ${ }^{84}$

\footnotetext{
${ }^{83}$ Posner, Antoine Watteau, 200.

${ }^{84}$ Wildenstein, Lancret, 99; the suggestion that this work is a portrait of the artist's family is tenuous at best. Wildenstein cited the owner of the painting at the time of his publication as the source of this information but does not offer any other sources to corroborate this statement.
} 
It is not clear if Lancret completed La fin de chasse or Le repas au retour de chasse (figure 46) first, since they are both dated to 1725. However, it appears that La fin de chasse may have come first since it would logically follow that he depicted a hunting party at rest in a landscape before he depicted a hunting party enjoying a meal in a landscape. Since Le repas au retour de chasse was not shown at the 1725 Salon until August it could be that La fin de chasse did in fact come first. There is no way to definitively answer this question. However, it can be said that Le repas au retour de chasse may be the first painting in which Lancret combines the subject of the hunt with that of dining and the two paintings can then be seen as instances of the artist developing his narrative of hunt luncheon paintings. Lancret took imagery from traditional representations of the hunt and combined it with the fêtes galantes of Watteau and the Northern genre of outdoor meals. This combination of themes was also not lost on the eighteenth-century viewer, given the description of the painting in the Mercure which notes that both the men and women were wearing riding clothes and that a meal was being eaten. ${ }^{85}$ Notably, however, the Mercure did not comment on how this subject matter was new to French genre painting; it may have been taken for granted that the hunting party was stopping for a meal, given the realities of the aristocratic pastime during which this was a regular occurrence.

${ }^{85}$ Wildenstein, Le Salon de 1725, 46. 


\section{Hunt Luncheon Paintings}

It appears that Lancret was the first artist to combine the aspect of dining with that of the hunt during the eighteenth century, at least with any frequency. ${ }^{86}$ These paintings have alternatively been called hunt picnics or hunt meals, but this dissertation uses the designator "hunt luncheon." Not all the images by Lancret can be called picnics since the term typically implies a table cloth laid on the ground. Many of the hunt luncheon paintings depict tables and are more formal than the informality implied by the term picnic. "Meal" is a vague term that gives no reference to the time of day that these meals occurred. The French word déjeuner typically refers to lunch and, to English speakers, petit déjeuner refers to breakfast; however, during the eighteenth century the times these meals were taken shifted. Déjeuner typically occurred at noon or later, so a petit déjeuner was eaten earlier, if at all. Therefore, the timing of these meals during the day is more reflective of our modern-day notions of lunch, or even brunch. ${ }^{87}$ Additionally, during the hunt, the halte during which these meals were taken occurred at various times throughout the early morning into the afternoon, the typical time of lunch. Finally, luncheon is a term

\footnotetext{
${ }^{86}$ It should be noted that François Lemoyne also painted two hunt luncheon which have been dated to 1723; one in Munich and almost an exact copy in São Paulo. However, there is evidence that both paintings were reworked later. It seems as though Lemoyne would have seen Lancret's Le repas au retour de chasse from the same year, since it is well documented that they were great friends, and altered a painting depicting the rest of a hunting party to reflect this development by Lancret. Lemoyne's work is also heavily indebted to Watteau's Rendez-vous de Chasse borrowing the figures of the man helping the woman from her horse. Watteau, in turn, borrowed this figural group from a print by Jacques Callot which has been well established by numerous scholars. See Sarah J. Sylvester Williams, "Dining and Revelry in French Rococo Art,” (Order No. 1503909, University of Missouri - Kansas City, 2011), http://proxy.mul.missouri.edu/login?url=https://search-proquestcom.proxy.mul.missouri.edu/docview/916901654?accountid=14576, 37.

87 Jim Chevallier, "The Queen's Coffee and Casanova's Chocolate: The Early Modern Breakfast in France” in Consuming Culture in the Long Nineteenth Century: Narratives of Consumption, 1700-1900 eds. Tamara S. Wagner and Narin Hassan (Lexington Books, 2007), 195-196.
} 
that is more suitable to these images given that many of them include the word déjeuner in their French titles.

Between Lancret's earliest expression of the hunt luncheon theme in 1725, seen in La fin de chasse and Le repas au retour de chasse, and its apex in the mid-1730s, the artist depicted the theme in at least four other paintings, more than any other artist during the period. These hunt luncheon paintings will be further investigated in Chapter Four. During this period, Lancret also depicted a multitude of paintings which follow the themes of the fête galante as exemplified by Watteau. Lancret concerns himself with paintings of music, social gallantry, and dancing, contained within forested landscape settings. His paintings of the early 1730s mostly depict the act of dancing, and his portraits of Mademoiselle Carmago (figure 55) and Madame Sallé, two popular dancers, represent the continued influence of theatrical subjects on Lancret's work. His compositions still echo those of Watteau despite creating his own particular style of figural representation. In addition to the forested setting of these works, Lancret continued to depict architectural elements such as partial walls, statues, and fountains that all take Watteau's works as their precedents. Lancret's paintings of the late 1730s and 1740s continue to exhibit the same compositional elements of his earlier works, though the number of figures diminishes, and they become larger and a more prominent element of the composition.

\section{Follower or Innovator?}

Throughout his entire career, Lancret was heavily influenced by Watteau. However, numerous scholars have simply dismissed him and his artistic production as 
that of a mere imitator. This evaluation of Lancret does not take into account the numerous and various ways the artist manipulated the standards of the fête galante as depicted by Watteau to achieve his own purposes. Additionally, the artist developed a specific figural style which is not to be confused with Watteau's, despite his borrowing of poses and figural compositions. In his paintings of kitchen women, the aristocratic pastime of hunting, and scenes of dining, Lancret found an inspiration in the themes and subjects of Watteau's paintings and Northern Renaissance and Baroque works. By taking the traditions of genre painting and imbuing his works with "the visual power and narrative coherence of history painting" and iconographic staffage, Lancret developed clear narratives for a refined and learned viewer. ${ }^{88}$

The combination of the narrative aspect of history painting with iconography deepened the subject of Lancret's paintings; at the same time, the iconography allows for a multitude of interpretations based on the viewers' own inclinations. Due to the narrative aspects of history painting, the eighteenth-century viewer would have been able to imagine themselves in the world depicted by Lancret, while the iconography of the images made them more contemporary and filled them with objects that the viewer owned or would have been familiar with. It is this subtle combination of iconography and genre painting with history painting that distinguishes Lancret's more contemporary fantasies from Watteau's timeless ones.

This iconography lends itself to the subject matter of the paintings in a way that Watteau's paintings did not display. As Holmes rightfully notes, "if superficially the

\footnotetext{
${ }^{88}$ Holmes, Nicolas Lancret: Dance Before a Fountain, 24.
} 
works retain the appearance of genre, they are supported by an underpinning of iconography." ${ }^{" 89}$ The iconography, such as the instance of the grapes in L'Automne, are central to the identification of the scene as a representation of the seasons; while the grapes depicted in Watteau's Le Lorgneur are not necessary to read the implications of the scene. This iconography is evidence of the influence of Northern Renaissance and Baroque painters on their eighteenth-century French counterparts. Not only does this iconography have roots in Northern paintings, but the serial nature of paintings such as the seasons, months, or times of day also have numerous Dutch and Flemish predecessors. More than this, however, Northern painters had long been producing works that depicted dining scenes and peasant festivals that were not a part of the French repertoire. The influence of the North is the subject of the next chapter.

${ }^{89}$ Holmes, Nicolas Lancret: Dance Before a Fountain, 27. 


\title{
Chapter Two - Lancret and the North
}

\begin{abstract}
In short, the northern and southern Netherlands were conflated in the minds of many into a quasi-utopian place of liberty, gaiety, goodness, industry and abundance. ${ }^{90}$
\end{abstract}

Vivian Lee Atwater

\section{Overview}

The influence of Dutch and Flemish paintings on French artists of the eighteenth century is well-established. With regard to specific eighteenth-century artists, most of the scholarly literature surrounds Watteau, since he was from Valenciennes, a borderland fraught with disputes of ownership between France and its northern neighbors, as was the slightly later artist, Jean-Baptiste-Siméon Chardin (1699-1779), who is known for his still-life paintings. However, even before Watteau's arrival in Paris, collectors had amassed innumerable Northern paintings and popular prints. This chapter focuses on both the influence of Watteau in Lancret's choice of Northern subjects and the Northern paintings to which Lancret may have had access through the collections of his patrons and the Académie.

Lancret formulated a French mode for garden parties and peasant festivals that drew upon both Northern traditions and paintings by Watteau, Teniers, and van de Velde. In short, these paintings and the proliferation of Northern paintings and prints of similar subjects in the French art market can be seen as a retaliation against the absolutism of Louis XIV and a reflection of the newfound freedoms of courtly society under Louis XV. Since Northern paintings were readily available in Paris, it is useful to investigate the vogue for them during the eighteenth century before discussing the differences between the Dutch and Flemish manner of paintings versus the French manner. Once I lay this

\footnotetext{
${ }^{90}$ Vivian Lee Atwater, "The Netherlandish vogue in print culture in Paris, 1730-1750" in Simiolus: Netherlands Quarterly for the History of Art, Vol. 34, No. 3/4 (2009/2010), 249.
} 
groundwork, I will discuss the influence of Northern paintings as disseminated through Watteau before I turn to the analysis of paintings by Lancret that had precedent in Northern versions. While members of the aristocracy were still very much concerned with issues of class distinctions through dress and social conformity, genre paintings depicting garden parties and country life allowed them the freedom to view themselves in an idealized way that was much less restricted than their actual life.

\section{The Taste for Northern Art in Eighteenth-Century France}

Northern artists had long travelled between their homes in the north and the French court to the south. Artists such as the Limbourgh brothers (1385-1416) worked for the Duc de Berry, Jean de Berry (1340-1416), in the fifteenth century and countless unnamed or unidentified Northern artists presumably worked throughout France centuries before and after. The ebb and flow of Northern artists in and out of the French court must have been substantial. The most obvious example of this fluidity of travel is of course Rubens and his commission from Marie de' Medici (1575-1642), the wife of the French king, Henry IV (1553-1610), in the early seventeenth century. Additionally, Anthony van Dyke visited Paris a few times in the mid-seventeenth century. The recorded travels of these well-known artists are just a few examples. It is impossible to know how many lesser and unnamed artists traveled between Paris and the North, leaving little or no record.

During the early- to mid-seventeenth century, communities of Northern painters living and working in Paris tended to gather together. The Faubourg St.-Germain-des- 
Près was home to one of the more well-known communities. ${ }^{91}$ Mickaël Szanto has surmised that the influx in Northern artists moving to this Faubourg coincided with the uptick in the number of Northern art dealers setting up shop in Paris. ${ }^{92}$ Since the late fifteenth century, St.-Germain-des-Près had hosted one of the three main market fairs and had been a major trading center for Northern art dealers in Paris. ${ }^{93}$ In addition to dealers, painters would often travel to the fair. ${ }^{94}$ It makes sense then that Northern artists would gravitate to this part of the city. Watteau himself was presumably drawn towards the St.Germain fair upon arriving in Paris as many his early supporters in the city were similarly Flemish. $^{95}$

The famed art dealer Edmé-François Gersaint not only bought paintings in Amsterdam to be resold in Paris, but also appropriated the Northern practices of public auctions and sales catalogues. ${ }^{96}$ It was Northern art dealers who had first advertised large public sales though printed posters and leaflets. These dealers also initiated auction catalogues, which were little more than inventories that were only published in rare instances such as Rubens's post-mortem sale. ${ }^{97}$ Due to political and economic reasons, in

\footnotetext{
${ }^{91}$ Scholars have continually noted that the French did not necessarily distinguish between Dutch and Flemish artists. This dissertation uses the term Northern as a descriptor instead of Dutch or Flemish in keeping with the eighteenth-century trends.

${ }^{92}$ Mickaël Szanto, "Antwerp and the Paris Art Market in the Years 1620-1630” in Mapping Markets for Paintings in Europe, ed. Neil De Marchi and Hans J. Van Miegroet (Turnhout, Belgium: Brepolis Publishers, 2006), 329.

93 Szanto, "Antwerp and the Paris Art Market," 329-330.

94 Szanto, "Antwerp and the Paris Art Market," 331-333.

95 Guillaume Glorieux, «Watteau et le Nord » in Watteau et la fête galante : Musée des beaux-arts de Valenciennes, 5 mars-14 juin 2004 (Paris : Éditions de le Réunion des musées nationaux, 2004), 46.

${ }^{96}$ Neil De Marchi and Hans J. Van Miegroet., "How Netherlandish paintings came to Paris" in Rubens, van Dyke, Jordaens et les autres : peintures baroques flamandes aux Musées royaux des beaux-arts de Belgique by Musée Marmottan (Paris : Hazan : Musée Marmottan Monet, 2012), 36-40.

${ }^{97}$ Dries Lyna and Filip Vermeylen, "Rubens for Sale. Art Auctions in Antwerp during the Seventeenth and Eighteenth Centuries" in Art Auctions and Dealers: The Dissemination of Netherlandish Art during the Ancien Régime, ed.Dries Lyna, Filip Vermeylen, and Hans Vlieghe (Tournhout: Brepolis Publishers, 2009), 145 .
} 
the early seventeenth century the art markets of Antwerp sought out new foreign markets for the sale of Northern paintings; Paris was one of the cities where numerous partnerships were formed. ${ }^{98}$ Not only were new paintings specifically supplied for this new foreign market, but older paintings were bought and sold within the partnership. ${ }^{99}$ Dealers such as Gersaint made buying trips to the Low Countries; it was there that he discovered the use of auctions and catalogues that were advertising techniques not previously seen in France. Gersaint's first trip north appears to have occurred in 1733, with additional trips annually until $1738 .{ }^{100}$ Gersaint used other methods, such as bundling like-subject paintings, offering buyers viewing days, and offering informed value judgments on paintings which helped form the French taste of collectorship. ${ }^{101}$ The main focus of the dealer's sales was in the reselling of works rather than selling new ones. That was quite unusual given the dealer's early location on the Pont Notre-Dame, a low-end artistic center. ${ }^{102}$ While Gersaint's dealings somewhat postdate Nicolas Lancret's interest in Northern subject matter, the example of the famous dealer is evidence of the constant selling, buying, and reselling of Northern paintings and prints that occurred in Paris during the eighteenth century, and perhaps even Lancret's own works.

Prints of paintings by Northern artists also proliferated and Parisian printmakers made innumerable copies that were sold to collectors and the public alike. Vivian Atwater has noted that the art-buying community consumed prints after Dutch and

\footnotetext{
${ }^{98}$ Lyna and Vermeylen, "Rubens for Sale," 139-40.

${ }^{99}$ Lyna and Vermeylen, "Rubens for Sale," 140-143.

${ }^{100}$ Neil De Marchi and Hans J. Van Miegroet “Transforming the Paris Art Market, 1718-1750" in Mapping Markets for Paintings in Europe, ed. Neil De Marchi and Hans J. Van Miegroet (Turnhout, Belgium: Brepolis Publishers, 2006), 390.

${ }^{101}$ Lyna and Vermeylen, "Rubens for Sale," 146-48.

102 De Marchi and Van Miegroet "Transforming the Paris Art Market, 1718-1750," 384-85.
} 
Flemish paintings with great fervor. ${ }^{103}$ She rightfully states that "These prints help to define the formative phase of interest in Dutch and Flemish paintings of the previous century... and the remarkable relationship between the Netherlandish vogue and developments in French painting." ${ }^{104}$ The two primary printmakers, arbiters, and adherents of taste during the early part of the eighteenth century were Jean Moyreau (1690-1762) and Jacque-Philippe Le Bas (1707-1783). Atwater notes that the first artists most reproduced during the early 1700s were Rubens and van Dyck. The 1730s saw the rise of prints after the works of Wouwermans and Teniers, two artists important to Lancret, and was a period rife with reproductions of Northern paintings. ${ }^{105}$ Moyreau had access to the collections of major art patrons such as the Comtesse de Verrue, Crozat, Gersaint, and Jullienne. ${ }^{106}$

Crozat, the Comtesse de Verrue, and Lériget were important art collectors during the early part of the eighteenth century, as mentioned in Chapter One. Among their collections were numerous paintings by Northern artists. Crozat, the Comtesse, and the Marquis all owned works by Rembrandt, van Dyck, Rubens, Wouwermans, Dou, and Teniers. Crozat and Lériget's collection even included a work by Breugel ${ }^{107}$ Crozat was a well-known collector who often sponsored artists, letting them live with him and view his collections. He also hosted weekly concerts that artists were invited to attend. Lancret produced a painting and an oil sketch depicting concerts at Crozat's Montmorency

\footnotetext{
${ }^{103}$ Vivian Lee Atwater, “A catalogue and analysis of eighteenth-century French prints after Netherlandish Baroque paintings" (Order No. 8826363, University of Washington, 1988), http://proxy.mul.missouri.edu/login?url=https://search-proquestcom.proxy.mul.missouri.edu/docview/303592064? accountid=14576., 66.

104 Atwater, A catalogue and analysis, 10.

${ }^{105}$ Atwater, A catalogue and analysis, 71.

${ }^{106}$ Atwater, A catalogue and analysis, 74.

${ }^{107}$ See Ziskin, Sheltering Art, Appendix 1-3.
} 
country home and his hôtel on the rue de Richelieu around 1719. While Crozat did not actually commission any works from Lancret, that Lancret was able to depict Crozat's two different homes in such detail exhibits the artist's intimate knowledge of the spaces.

Additionally, since Crozat saw himself not just as a collector but also an educator, Lancret presumably would have been familiar with Crozat's collection of paintings and drawings, which totaled almost twenty-thousand works upon the collector's death. ${ }^{108}$ Lancret similarly would have had access to the collection of Lériget since he worked at his château and received a commission for his Parisian hôtel, as previously discussed. While it is unclear if Lancret would have had access to the collections of the Comtesse, he may have since she and Lériget had a very close relationship; Lériget bought the Château de Condé from Verrue's son-in-law. ${ }^{109}$ Furthermore, Lériget and the Comtesse were two key figures in the circle of Moderns who collected contemporary French works alongside seventeenth-century Northern paintings. ${ }^{110}$

\section{Northern Manner versus French Manner}

As the quote opening this chapter indicates, there was something about paintings by artists such as Teniers that communicated ideas of rural rusticity and bucolic ideals. The North appeared as a place uncorrupted by pretense and the restrictions of urban life and especially courtly culture. These were paintings of happiness and harmony between men and between man and nature. French paintings inspired by Northern genre scenes

\footnotetext{
108 Mary Tavener Holmes, "Nicolas Lancret and the Tail of Three Collectors" in French Art of the Eighteenth Century: The Michael L. Rosenberg Lecture Series at the Dallas Museum of Art ed. Heather MacDonald (New Haven: Yale University Press, 2016), 55-60.

109 Ziskin, Sheltering Art, 96.

110 Ziskin, Sheltering Art, 93.
} 
tend to show labor as an idealized and enjoyable pastime as opposed to the tedious, backbreaking work it actually was. However, Northern paintings themselves omitted many of the arduous aspects of rural life, for example, harvesters relax in the shade, and the most demanding work is not shown. ${ }^{111}$ A simple examination of Pieter Breugel's (1525-1569) famous series of the months commissioned by the Antwerp merchant Nicolaes Longelink (1517-1570) confirms this. Through the French adaptation of Northern genre scenes, the depictions become even more fanciful; acts of lower class manual labor are made into high society acts of leisure. The ideas of gaiety in industry and the romaticization of rural life is evident in the paintings by Lancret much earlier than those who often receive the most credit for furthering this idea: the artist François Boucher; Jeanne Antoinette Poisson (1721-1764), better known as Madame de Pompadour, and Marie Antoinette.

Paintings in the Northern manner typically depict genre scenes or subjects that were viewed to be lesser than the lofty subjects, such as history painting and mythology touted by the French academy. Images of peasants, festivals, flowers, food, and the mundane aspects of everyday life abound. These paintings typically use a much more restrained color palette, sticking to earthy colors such as a wide variety of browns, greens, yellows, reds, and oranges. This is not exclusively the case, since painters such as Rubens and van de Velde used a wider color palette including pinks and blues. Rubens' works particularly have a shimmering quality that highlights the high social ranking of their participants. But artists such as Bruegel tended to use an earthier palette with flatter

\footnotetext{
${ }^{111}$ Walter S. Gibson, Pleasant Places: The Rustic Landscape from Bruegel to Ruisdael (Berkley, University of California Press, 2000), 175.
} 
expanses of unmodulated color that seem to match the lowly character of the figures in his paintings.

Watteau is the artist credited for bringing Northern traditions of paintings to Paris during the eighteenth century. His earliest training as an artist was in Valenciennes, which, as previously noted, is on the border between France and the Netherlands. In his hometown, Watteau's earliest artistic training was possibly from Jacques-Albert Gérin (1640-1702), a native of Valenciennes working in the Northern tradition. ${ }^{112}$ It is well known that Watteau actively looked to Rubens for inspiration; he translated Rubens's theme of the Garden of Love into a French style with the popularization of the fête galante. Rubens's Garden of Love (figure 56) is seen by scholars as “a major link in the chain of love gardens from the Middle Ages to the Rococo."113 The settings of Rubens's paintings are typically gardens or parks whose locations are an excuse for leisurely dalliances and music-making. These paintings of love scenes were widely collected during the seventeenth century in Flanders and Holland. ${ }^{114}$ The themes of courtship and promenading were then translated into the French style by Watteau. Following the influence of Rubens, Watteau included cupids in his first fête galante, Pèlerinage à l'île de Cythère (figure 1). Later these cupids were turned to stone and appear as statuary sometimes alongside Venus in Watteau's paintings. Scholar Elise Goodman has noted that Rubens's painting Château in a Park (figure 57) serves as a direct precursor to Watteau's paintings, though the elder artist's figures remain slightly larger in relation to

\footnotetext{
112 Glorieux, « Watteau et le Nord », 45.

113 Elise Goodman, Rubens: The Garden of love as "Conversatie à la mode” (Amsterdam/Philadelphia: John Benjamins Publishing Company, 1992), 1.

${ }^{114}$ Goodman, Rubens, 12-13.
} 
the landscape than the younger artist's. ${ }^{115}$ Additionally, Watteau both knew and admired the Kermesse painting (figure 58) by Rubens in the Louvre which was acquired by Louis XIV in $1685 .{ }^{116}$ Watteau along with those of his other native Flemish artists may have been drawn to the color and naturalism of Rubens's works. ${ }^{117}$

While the German printmaker Sebald Beham (figure 59) has been credited with the development of peasant festival scenes, it was Bruegel who seems to have popularized it a few decades later; as scholar Alison Stewart has pointed out, Beham's obscurity with regards to the creation of this genre type may be due in part to his medium. ${ }^{118}$ Stewart argues that, “[Pieter] Bruegel's works are also painted on wooden panel, not printed on paper, and thus their material supports have functioned as unconscious co-conspirators in art history's privileging of painting over prints." 119 Yet the comparison of eighteenth-century paintings to Northern Renaissance paintings is a more fruitful endeavor, as many scholars have already established the links between the two. Furthermore, it is unclear to what extent French artists may have had access to these early German prints; regardless, the peasant festivals depicted by French artists have more in common with the Flemish and Dutch successors of German prints than they do with Beham's initial openly scatological conceptualization of the genre. Additionally, in a way very similar to eighteenth-century French works, the Northern Renaissance and Baroque paintings and prints were disseminated in a vast and far-reaching manner. Not

\footnotetext{
115 Goodman, Rubens, 15-16

116 Banks, Watteau and the north, 138.

117 Philip Conisbee "The Eighteenth Century: Watteau to Valenciennes" in Claude to Corot: The Development of Landscape Painting in France edited by Alan Wintermute (New York: Colnaghi, 1990), 88.

118 Alison G. Stewart, Before Bruegel: Sebald Beham and the Origins of Peasant Festival Imagery (Burlington, VT: Ashgate Publishing Company, 2008), 1.

${ }^{119}$ Stewart, Before Bruegel, 1-2; Stewart notes another reason as that of the preference of Netherlandish paintings over German prints.
} 
only the well-known artists, but also paintings by lesser-known artists were consumed in the Parisian art market, adopted, and converted into a French idiom. This transference was not specific to any one subset of genre painting, since "throughout the eighteenth century, there were all kinds of novel appropriations and transformations of Netherlandish characteristics in French paintings." ${ }^{120}$ Similar to Lancret's appropriation of Northern peasant festivals, other artists had adapted other characteristically Northern painting techniques such as flower garlands, and, of course, the still life paintings for which Chardin is known. ${ }^{121}$

Oliver Banks demonstrates Watteau's connections to these Northern artists and even discusses Lancret's indebtedness to Willem Kalf (1619-1693) along the way. ${ }^{122}$ The author also thoroughly discusses the seventeenth-century precedents for Watteau's fête galante paintings, citing both Dutch and Flemish examples extensively. Teniers and Adriaen van Ostade (1610-1685) were highly influential for Watteau's oeuvre. But arguably more so Teniers, as Banks notes that he was the source of inspiration for Watteau's village wedding scenes, La Mariée de village (figure 60) and L'Accordée du village (figure 61). Both artists depict the bride as the center of the composition and utilized drapery as a backdrop; both are able to integrate a large number of figures coherently and use light as a means to achieve spatial unity. One of the main compositional techniques that Watteau may have learned from Teniers, which was discussed previously, is the artist's use of trees to screen the background of paintings. ${ }^{123}$

\footnotetext{
${ }^{120}$ De Marchi and Van Miegroet., "How Netherlandish paintings came to Paris," 35.

${ }^{121}$ See De Marchi and Van Miegroet., "How Netherlandish paintings came to Paris," 35 for a further discussion on the French adaptation of Northern paintings.

122 Banks, Watteau and the north, 126-127.

${ }^{123}$ Banks, Watteau and the north, 135-137.
} 
Banks briefly notes that Watteau borrowed compositional elements found in Teniers' paintings and the later artist's disinterest in Teniers' rustic peasantry in favor of the more aristocratic figures. ${ }^{124}$ With regard to Lancret, the painting Fête in a Wood (figure 22) is evidence that the artist was able to incorporate a large number of people into a landscape very proficiently. Despite the considerable number of figures appearing in paintings by both Teniers and Watteau, it can be assumed that this was not the type of painting Lancret preferred to work on, given that this is the only painting by the artist that is so densely populated.

The French manner advanced by Watteau and Lancret is inarguably a more refined version of the Northern manner. The coloring of the images is similar to Rubens and van de Velde, but the figures are slimmer and more waifish than the voluptuous, curvy bodies of Rubens. Even the thinner figures of van de Velde have a more static, weighty quality to them that those of the French artists. The poses of the figures in French paintings, although obviously highly contrived, have a spontaneity of action not seen in many paintings in the Northern manner, giving the French paintings more of an immediacy than their Northern counterparts.

\section{Lancret and Northern Art}

While Watteau's personal knowledge of the painters and paintings from his onceFlemish hometown of Valenciennes helped to create the shift away from the pomp and grandiose display of Baroque art to a more contemporary depiction of aristocratic values and ideals, other factors were just as important. The director of the Académie during the

\footnotetext{
${ }^{124}$ Banks, Watteau and the north, 136.
} 
height of Lancret's activity, Antoine Coypel, publicly promoted the Dutch and Flemish schools of art in an address given on December 7, 1720. ${ }^{125}$ Coypel's defense of the Northern arts was given just over a year and a half after Lancret achieved the status of reçu. In 1727 Antoine-Joseph Dézallier d'Argenville's (1680-1765) proclaimed the tasteful nature of Dutch and Flemish paintings in the Mercure de France, the most widely circulated review in France. ${ }^{126}$ However, as early as 1721 the Mercure noted the increase in popular demand for paintings that exhibited le gôut flamand possibly as a response to the popularity of paintings by Watteau. ${ }^{127}$ Patrick Michel has suggested that "What was valued in Flemish painting was its ability to affect and to depict a form of reality." ${ }^{128}$ This reality was often an idealization of the peasant life. It eschewed all, or most, of the arduous tasks and manual labor and focused on the imagined virtuousness of rural life and the fecundity of the countryside's flora and fauna.

In addition to the rustic subjects of Northern paintings, it was their "naivety of expression" that Coypel addressed as an inimitable quality of painting. ${ }^{129}$ Coypel's address also lauded the Northern painters' imitation of nature, specifically that of Kalf: "Kalf, in the objects he imitated from nature, seems to me to speak the language of paintings as well as Giorgione and Titian." ${ }^{130}$ Coypel discussed Rembrandt, Rubens, and

\footnotetext{
${ }^{125}$ Atwater, "The Netherlandish vogue," 240.

${ }^{126}$ Atwater, "The Netherlandish vogue," 240-241.

${ }^{127}$ Atwater, "The Netherlandish vogue," 241.

${ }^{128}$ Patrick Michel, "French Collectors and the Taste for Flemish Painting during the Eighteenth Century" in Art Auctions and Dealers: The Dissemination of Netherlandish Art during the Ancien Régime, ed. Dries Lyna, Filip Vermeylen, and Hans Vlieghe (Tournhout: Brepolis Publishers, 2009), 127.

${ }^{129}$ Antoine Coypel, Discours prononcez dans les conférences de l'Académie royale de peinture et de sculpture (Paris : De l'imprimerie de Jacques Collombat, 1721), 22.

${ }^{130}$ Coypel, Discours prononcez dans les conférences de l'Académie royale de peinture et de sculpture, 22 ; «Le Calfe, dans les objets qu'il a imitez d'après nature, me paroit parler le langage de la peinture aussibien que le Giorgione et le Titien, avec la différence, qu'il ne sait pas dire d'aussi grandes choses que ces grands maitres de l'art. »
} 
Anthony van Dyke in his address on color, brushwork, contour, and other aspects of great artists and art. He stated that the most common subjects, even the lowly ones, of the Northern painters such as Rembrandt and Dou contain simple truths and a naiveté that was very admirable. ${ }^{131}$ Coypel made this remark when discussing the passion with which a painter should work and how they should imbue their figures with a soulful quality through gestures and bodily action lest their paintings be cold and inanimate. ${ }^{132}$ As director of the academy, Coypel was advocating for paintings that express the same gaiety and simple subject matter of these Northern artists. The call to emulate Kalf must have specifically appealed to Lancret and the importance of Northern artist did not fall on deaf ears.

The influence of Kalf on Lancret discussed by Banks was short-lived as the paintings that resemble Kalf's tend to be from Lancret's early flirtations with Watteau's style and subject matter. Watteau was apparently familiar with Kalf through his friend and fellow painter Nicolas Vleughels (1668-1737), who may have owned paintings by the Northern artist. ${ }^{133}$ Lancret may have known of Kalf's works independently of his emulation of Watteau. Kalf lived and worked in Paris during the 1640s, so paintings by the artist would have been prevalent in the Parisian market. La Chercheuse de Puces

\footnotetext{
${ }^{131}$ Coypel, Discours prononcez dans les conférences de l'Académie royale de peinture et de sculpture, 162 ; «Dans les Flamands, Rubens, dont il faut cependant démêler ce que le gout et la nature de son pays lui ont pu donner de détracteur. Parmi les ouvrages des Hollandais, on trouvera dans les sujets les plus communs et même le plus bas, une vérité simple et naïve très-estimable, comme dans Rembrandt, Giraardou et plaisirs autres. Parmi les Allemands, vous trouverez encore Albert-Dure le même naïf et le même vraie dans les gestes : l'estime du Grand Raphael fait mieux son éloge qui tout ce que j'en pourrisse dire. »

${ }^{132}$ Coypel, Discours prononcez dans les conférences de l'Académie royale de peinture et de sculpture, 151 ; «Après avoir eu l'honneur de vous entretenir, Messieurs, de l'expression générale et des caractères, je dois parler de l'expression des passions qui se fait par les mouvements du corps ou par les gestes qui doivent donner de l'amé aux figures, et sans lesquels, les tableaux les mieux composez, les mieux dessinez, peints et coloriez, seraient froids, languissants et inanimé; car, comme le remarque Cicéron, l'action est l'éloquence du corps. »

${ }^{133}$ Banks, Watteau and the north, 126.
} 
(figure 11), La Cuisine (figure 12), Kitchen Interior (figure 13), Le Nègre et La

Cuisinière (figure 14), Le Galant Valet (figure 15) all mentioned in Chapter One, fall into Lancret's early, more derivative period of production. The domestic interior of the scenes and the darker tonalities are reminiscent of Kalf; however, Lancret's distinct figural style is apparent.

Altering paintings was not an uncommon artistic practice during the period. In a similar instance, Watteau added figures to a painting by Francisque Millet the Younger (1666-1723). Watteau also added figures strolling through a landscape which was originally by Henry Ferguson, a Scottish-Dutch artist. ${ }^{134}$ Other instances of altered images such as Lancret's include Oudry's additions of dogs and a stag to a painting by Jan Breughel (1568-1625) and Boucher's adding figures to an equestrian painting by the English artist George Stubbs (1724-1826). ${ }^{135}$

The key identifier of a painting's alteration by Lancret is the juxtaposition of the dark backgrounds with the brightly-dressed eighteenth-century figure. This distinctive feature is seen in the paintings La Cuisine and Le Valet Galant in addition to a painting entitled La Grange. Wildenstein notes a copy of Valet Galant which appeared in an 1811 sale; however, this painting is a copy of the one in the Hermitage and should not therefore necessarily be included in the total number of paintings by Kalf or other Northern artists that Lancret may have "rejuvenated."136 Georges Batz has claimed that Lancret did not paint any of the works that can be labeled as Cuisines, suggesting that the

\footnotetext{
${ }^{134}$ Martin Eidelberg, "The Case of the Vanishing Watteau," Gazette des Beaux-Arts 138 no 1590/91 July/August 2001, 15-40.

135 David Pullins "Stubbs, Vernet, \& Boucher Share a Canvas: Workshops, Authorships \& the Status of Painting” Journal18 1 (Spring 2016), http://www.journal18.org/334

${ }^{136}$ Batz, "French Cusines." Art Quarterly Vol. 9 No. 1 (1946), 309.
} 
artist's alteration of Northern images reflected the changing taste of the art market. Batz reiterates Wildenstein's assessment of the above-mentioned paintings but added that $L a$ Chercheuse de Puces, La Cuisinière, and Cuisine de Compagne are additional images that Lancret may have altered - paintings which Wildenstein did not acknowledge as probably containing only added figures by Lancret. ${ }^{137}$ Unfortunately the present locations of La Cuisinière, Cuisine de Compagne, and La Grange are unknown, so an extensive analysis of these paintings is not possible. However, from Wildenstein's description of $L a$ Cuisinière we can get a rough idea of what it may have looked like. Wildenstein described the painting as "The interior of a kitchen: a woman seated with vegetables beside her is seen in the front. This picture is as beautiful as if it were from Kalf." ${ }^{\prime 38}$ The description of Cuisine de Compagne comes from the posthumous sale of Madame Lancret's possessions, and the document describes the painting as "a country kitchen, in the background, a pot on the fire under a chimney; in the front, a woman carrying a child, and two men, one of whom unties a sheaf of wheat." ${ }^{139}$ The final painting, La Grange, is described as "an original painting by Herman Zagtlieven, a Dutch painter, in the style of Kalf. It represents a barn with all the instruments and cookware, adorned with three small figures painted by Lancret. Its frame is of gilded wood." ${ }^{140}$ Without physically inspecting the paintings, it is impossible to discern what, if any, additions other than the figures were added by Lancret.

\footnotetext{
137 Batz, "French Cusines," 309; Wildenstein, Lancret, no. 517, 527, 531.

${ }^{138}$ Wildenstein, Lancret, 105, «L'intérieur d'une cuisine : on voit sur le devant une femme assise avec des légumes auprès d'elle. Ce tableau est beau comme s'il étoit de Kalf. »

${ }^{139}$ Wildenstein, Lancret, 104, « une cuisine de campagne, dans le fond, une marmite sur le feu d'une cheminée ; sur le devant, une femme portant un enfant, et deux hommes, dont un délie une gerbe de bled.» ${ }^{140}$ Wildentstein, Lancret, 105 ; « un tableau original peint par Herman Zagtlieven, peintre hollandais, dans le gout de Kalf. Il représente une grange avec tous les instruments et batterie de cuisine, ornée de trois petites figures peintes par Lancret. Sa bordure est de bois uni doré. »
} 
While an analysis of La Cuisinière, Cuisine de Compagne, and La Grange is not possible, examining the other paintings by Lancret is. The two paintings La Cuisine (figure 12) and Le Valet Galant (figure 15) were acquired by Catherine the Great (17291796), a well-known patron of the arts. Catherine's collection of art now makes up the core of the Hermitage Museum. In a ten-year period, Catherine amassed an enormous collection of both Old Master paintings and contemporary ones. These two paintings may have been acquired in 1764 from the German merchant Johann Ernst Gotzkowski (17101775 ) in a collection of more than 200 paintings that were assembled for sale to Catherine's arch-rival Frederick the Great, another collector of paintings by Lancret. ${ }^{141}$ During the next decade Catherine purchased paintings belonging to illustrious collectors such as Jean de Jullienne and the heirs of Pierre Crozat. ${ }^{142}$

As early as 1773, it was theorized that only the figures in La Cuisine and Le Valet Galant are by the hand of Lancret and were later additions to earlier paintings by Kalf. ${ }^{143}$ La Cuisine was described by Alexandre Somof's 1899-1903 Catalogue de la galerie des tableaux de l'Ermitage. Ecole anglaise et école française as:

Behind a table covered with a red tablecloth is game, three apples on a pewter plate, a bunch of onions, a bunch of asparagus, a basket containing a chicken, and a large copper cauldron, a young housewife, dressed in a blue dress, examines a killed hare she raises from a chair by the hind legs. Near her on the right, the cook, wearing a gray skirt and a red camisole, explains something to her mistress. The scene takes place in a dark room,

\footnotetext{
${ }^{141}$ Natalya Gritsay, "Pages from the History of the Hermitage Collection of Flemish Paintings" in Rubens, Van Dyck \& Jordaens: Flemish Painters from the Hermitage, Hermitage Museum (Amsterdam: Kunstdrukkerij Mercurius, 2011), 11-13; It is unclear exactly when La Cuisine and Le Valet Galant came into Catherine's collections; the paintings are listed as works by Lancret on the online database of the Hermitage's collections giving no hint to their status as altered images.

${ }^{142}$ For a fuller description of Catherine's collecting see Sergei Androsov, "Two Pastimes of Catherine II: Collecting and Building" and Maria Garlova, "Catherine the Great's Collection of Paintings: The Purchase of Old Masters and the Acquisition of Contemporary Works of Art" in Catherine the Great: an enlightened Empress, National Museums Scotland (Edinburgh: NMS Enterprises, 2012).

${ }^{143}$ Alexandre Somof, Catalogue de la galerie des tableaux de l'Ermitage. Ecole anglaise et école, 53 ; « dans la catalogue manuscrit de la galerie, rédige en 1773-1783, il était dit que dans ces tableaux les figures seules appartenaient à Lancret et que tout le reste était dû au pinceau de Kalf, malgré que le premier des deux peintres n'avait que 3 ans à l'époque de le mort du second.» Wildenstein, Lancret, 104-105, no. $529,530,535$; all three of these entries by Wildenstein state that only the figures were painted by Lancret.
} 
badly illuminated by the window in the background. On the side, a stork killed, suspended from an iron ring. ${ }^{144}$

Somof's description of the woman as inspecting the hare does not seem quite accurate.

The young woman appears to be inspecting the groin of the animal in an instance of

Lancret's bawdy sense of humor which is in fitting with Northern paintings. According to

Somof's catalogue, La Cuisine and Le Valet Galant are pendants. Le Valet Galant is

described as:

Behind a stone table, covered with a lilac tablecloth and on which are several fish, apples, a pewter plate, a copper cauldron, a glass decanter, braided rush mat, onions, carrots and different vegetables, a valet, dressed in beige, wooed a young cook dressed in a strawcolored dress and wearing a little white cap; she shrinks from his gallantries. The scene happens in a dark room, poorly lit by the hard bottom window. To the right, a green drapery, half raised; on the left, a basket and two soles suspended from an iron ring. ${ }^{145}$

Neither description suggests the original artist of the painting. Given the popularity of

Northern paintings during the period, it is not surprising that Catherine the Great collected paintings by Rubens, van Dyck, Jacob Jordaens (1593-1678), Frans Snyders

(1579-1657), and Teniers alongside those of contemporary artists such as Lancret, Chardin, Jean-Baptiste Greuze (1725-1805), and Élizbeth Vigée Le Brun (1755-1842). Another painting with additions by Lancret is La Chercheuse de Puces (figure 11), currently in The Wallace Collection in London. Lancret added the figure of the

\footnotetext{
${ }^{144}$ Somof, Catalogue de la galerie des tableaux de l'Ermitage, 52-53, « Derrière une table recouverte d'une nappe-rouge est sur laquelle se trouvent du gibier, trois pommes sur une assiette en étain, un paquet d'oignons, une botte d'asperges, une corbeille contenant une poule, et un grand chaudron en cuivre, une jeune ménagère, vêtue d'une robe bleue, examine un lièvre tué qu'elle soulève d'une chaise par les pattes de derrière. Près d'elle à dr[oit], la cuisinière, vêtue d'une jupe grise et d'une camisole rouge, explique quelque chose à sa maitresse. La scène se passe dans une pièce sombre, mal éclairée par la fenêtre du fond. Du côté g[auche] de la pièce une draperie a moiti relevée et de l'autre côté, une cigogne tuée, suspendue à un cercle de fer. »

145 Somof, Catalogue de la galerie des tableaux de l'Ermitage, 53, «Derrière une table en pierre, recouverte d'une nappe lilas et sur laquelle se trouvent plusieurs poissons, de pommes, une assiette en étain, un chaudron en cuivre, un carafon en verre, tressé de jonc, des oignons, des carottes et différents légumes, un valet, en habit beige, courtise une jeune cuisinière vêtue d'une robe paille et coiffée d'un petit bonnet blanc; elle se dérobe à ses galanteries. La scène se passe dans une pièce sombre, mal éclairée par la fenêtre du fond. A dr[oit] une draperie verte, à moitié relevée ; à g[auche] un panier et deux soles suspendus à un cercle de fer. »
} 
seated woman in a pink and green striped silk dress inspecting herself for fleas. ${ }^{146}$ She sits in a kitchen interior with a small table to her left and a wooden partition to her right. Behind her are shelves laden with dishes, several them chipped, bowls, and other earthenware vessels. Apart from the woman, the rest of the painting is dimly lit and features dark, muted colors. The Wallace Collection catalogue notes that "fleas were a common complaint among the poorer classes in the eighteenth century, but the scene is intended primarily to titillate...the flea is to be envied for his ability to explore the rest of her body, which the viewer is shown but a tantalizing glimpse." ${ }^{147}$ Additionally, their online entry gives more information on the alterations made by Lancret. The artist added the seated figure of the woman, the still life on the table, and changed the back of the chair of an earlier painting. The tentative attribution of the interior scene to Kalf has not been proven. However, dendrochronology performed on the wood showed that it was painted after 1680 and is Flemish in origin. ${ }^{148}$ While the Wallace Collection has not removed the later additions by Lancret, other paintings have been restored and Lancret's later embellishments removed.

A painting previously attributed to Lancret, Kitchen Interior (figure 13), formerly called Valet Galant or even L'Offre du Nid, has been cleaned to remove the additions by the artist revealing the original painting by Kalf. ${ }^{149}$ The painting is currently in the

\footnotetext{
${ }^{146}$ Lancret reused this same posed woman in Le Nègre et la cuisinière and another painting in the Wallace Collection, Girls Bathing. See Stephen Duffy and Jo Hedley, The Wallace Collection's Pictures: A

Complete Catalogue (London: Unicorn Press and Lindsay Fine Art Ltd, 2004), 229, P408.

${ }^{147}$ Duffy and Hedley, The Wallace Collection's Pictures: A Complete Catalogue, 227.

148 “A Young Woman in a Kitchen," The Wallace Collection Online, accessed May 2017, http://wallacelive.wallacecollection.org/eMuseumPlus? service=ExternalInterface \&module=collection\&obj ectId=65312\&viewType $=$ detail View

${ }^{149}$ Batz, "French Cuisines," 308-309; in the case of Watteau's additions to Ferguson's painting having been removed Martin Eidelberg called the removal "a decisive blow" by to the painting and the museum who owned it, Eidelberg, "The Case of the Vanishing Watteau," 17. Eidelberg acknowledges the removal of figures from the Saint Louis painting and calls the removed additions "charming" he does not condemn
} 
collection of the Saint Louis Art Museum but was cleaned before its purchase in 1946.

Prior to its cleaning, the painting depicted a young man and woman in the dimly lit interior of a kitchen. The two figures were dressed in eighteenth-century garb and clearly identifiable as those typically by Lancret. The woman, presumably a maid, stood behind a well with her left hand resting on the ledge of the well and her right hand held by the man leaning in towards her slightly. Upon the painting's restoration, these two figures were removed to reveal a more plainly dressed woman original to the painting standing just left of the position of Lancret's female figure (figure 62). Lancret's male figure had obscured a squatting or seated male figure on the left-hand side of the painting a little behind the woman. The only other difference between the painting before and after its restoration is the reappearance of a chipped faience dish decorated with a blue and yellow pattern that Lancret overpainted.

Batz claims that Le Nègre et la Cuisinière (figure 14) is the only kitchen scene painted entirely by Lancret, disparagingly calling it "by far the weakest among the Cuisines." ${ }^{150}$ Unfortunately, this painting is only known through the black and white image printed in Wildenstein's monograph. It did appear in an exhibition in the nineteenth century where it was described as

A kitchen maid, dressed as a young lady, sits at a table, peeling vegetables; she interrupts this task to look under her bust for an intrusive parasite; while she is occupied in this search, a young negro has advanced cautiously, and with his hand resting on the back of the chair, he is immersed in an indiscreet look into the bodice of the frisky cook.

Everything is graceful and charming in this little scene. ${ }^{151}$

their removal in the same manner as he had the removal of Watteau's additions, Eidelberg, "The Case of the Vanishing Watteau," 30.

150 Batz, "French Cuisines," 310.

${ }^{151}$ Société archéologique et historique de l'Orléanais, Bulletin de la Société archéologique et historique de l'Orléanais No. 91 (Orléans, 1876), 447, http://gallica.bnf.fr/ark:/12148/bpt6k57183222; « Une cuisinière, en costume de demoiselle, est assisse à une table, en train d'éplucher des légumes; elle interrompt cette besogne pour chercher sous son fichu un importun parasite; pendant qu'elle est occupée à cette chasse, un jeune négrillon s'est avancé avec précaution, et, la main appuyée sur le dossier de la chaise, il plonge un 
While this entry gives a good description of the painting is says nothing of its coloring or quality, though it can be assumed that it may have resembled the Wallace Collection painting given the repetitive depiction of the figure of the woman.

The paintings to which Lancret added figures are instances of pastiche, which typically involved an artist making the painting in the style of another. Pastiche is typically used to describe an artistic work in a style that imitates that of another work, artist, or period, and is meant to be known as an imitation. Some of Lancret's instances of pastiche involve the literal reuse of older kitchen scenes by other artists. The definition of pastiche actually aligns with modern notions of forgery, but the practice during the ancien regime was viewed in a more positive manner, yet pastiche should be differentiated from forgery since it is not simply a mechanical copying of a painting. The addition of imagination to the act of imitation is what separates pastiche from forgery, that and the fact that it is meant to be known as imitation. Pastiche is also different from traditions of genre painting and an instance of ice skating in an eighteenth-century Rococo painting meant to depict winter should not be seen as a pastiche of Northern artists but simply conformity to artistic practices. Instead, the instances of pastiche by Lancret discussed in this dissertation ask the viewer to discern between old and new, and similar or dissimilar. ${ }^{152}$ This characteristic of pastiche then provides a better way in which to view the juxtapositions of old and new, dark interior and brightly clothed figures in these works altered by Lancret.

regard indiscret dans le corsage de la sémillant cuisinière. Tout est gracieux et coquet dans cette petite scène. »

152 Paula Radisich, Pastiche, Fashion, and Galanterie in Chardin's Genre Subjects: Looking Smart (Lanham, Maryland: University of Delaware Press, 2013), 44. 
Paula Radisich argues that the practice of pastiche became aligned with that of art collectors and connoisseurs during the 1730s and 40s. However, unlike other artists who utilized techniques of pastiche, Lancret added contemporary figures to older Northern paintings. In her investigation of eighteenth-century practices of pastiche, Radisich discusses Lancret's La Chercheuse de Puces as a painting that imitates the Dutch servant searching for fleas but does so wittily by adding an erotic and contemporary element to the painting through the servant's fashionable dress. Recent scholarship on collaborative paintings states that, "Lancret made a business of adding fashionably dressed eighteenthcentury figures to seventeenth-century Dutch interiors." ${ }^{153}$ However, this is not quite a true reflection of the artist's vast production. The same is true of the assessment that he was "a regular contributor of fashionable female figures to seventeenth-century kitchen scenes," given that only six known images of the artist's vast oeuvre are either readily identifiable altered images or presumed to be so. ${ }^{154}$ Yet these statements reflect the lack of scholarship on altered paintings such as these and indicate a more modern way of viewing these objects that may not have been viewed in the same way during their time. Provided the numerous artists who utilized pastiche, Lancret's paintings would not have been seen as anything out of the ordinary. It can be presumed that Lancret altered these older paintings to create one that combines the Northern aesthetic of the kitchen genre scene with more modern French figures. This may have allowed the artist to formulate ideas about his own artistic production based on his assemblage of older images.

\footnotetext{
${ }^{153}$ Pullins "Stubbs, Vernet, \& Boucher Share a Canvas: Workshops, Authorships \& the Status of Painting." ${ }^{154}$ David Pullins, "The individual's triumph: the eighteenth-century consolidation of authorship and art historiography," Journal of Art Historiography, Vol 16, (2017), 19.
} 
Lancret himself was known to have owned Netherlandish paintings by artists such as Rubens, Teniers, Rembrandt, Wouwermans, van Ostade, Adriaen Brouwer (16051638), and their followers. ${ }^{155}$ According to the documents of Madame Lancret's sale after her death in 1782, most of the Dutch and Flemish works owned by Lancret were engravings. He did, however, own several paintings "in the style of Teniers." Lancret owned two paintings by Rubens, a pastiche by Teniers of a work by Tintoretto, a summer and winter scene both by Teniers and a painting by van Dyke of a military scene, among other paintings by lesser-known Northern artists. ${ }^{156}$ In total, Lancret owned one hundred and seven works by Dutch and Flemish artists and twelve works by Italian artists. French artists made up the bulk of Lancret's collection, but only seventeen of these were paintings. Of the other hundred and forty-eight entries in this category, which included gouaches, miniatures, drawings, and prints, twenty-eight of them specifically reference works by or after the style of Northern artists. ${ }^{157}$ Interestingly, Lancret owned a number of religious paintings. This should not suggest that the artist was a religious man but a connoisseur who collected items based on his financial means, his affinities for certain artists, and his artistic eye.

Mary Tavener Holmes has noted another influence on Lancret's genre paintings; the artist relied on popular French prints such as those by Jean Mariette (1694-1774) discussed in detail below. ${ }^{158}$ While these prints offered a wealth of images of fashionable

\footnotetext{
${ }^{155}$ Holmes, Nicolas Lancret, 1690-1743, 48.

${ }^{156}$ Pierre Rémy, Catalogue de tableaux, dont le plus grand nombre des bons maîtres des trois écoles, de peintures à gouache \& miniatures, dessins \& estampes en feuilles \& sous verres, livres \& suites d'estampes, après le décès de Madame Lancret, \& de $M^{* *}$, par P. Rémy, cette vente se fera le mercredi 3 avril 1782, \& jours suivans, quatre heures de relevée, rue Plâtrière, à l'ancien Hôtel de Bullion (Paris : Frémin, 1782), 14-16. ; « dans le goût de Teniers »

${ }^{157}$ Rémy's catalogue entries often grouped images together so these figures are rough estimates. Whenever possible the author has tried to count the objects instead of relying on the number of catalogue entries.

${ }^{158}$ Holmes, Nicolas Lancret, 1690-1743, 14-16.
} 
people and pastimes, they do not include the subject of dining scenes. For images depicting dining, Northern Baroque paintings are an important source of inspiration. Holmes credits a slightly different list of Northern artists as the basis for fête galante paintings: Dirck Hals (1591-1656), David Vinckboons (1576-1632), Adriaen van de Venne (1589-1662), Willem Buytewech (1591-1624), Hieronymus Janssens (1624-1693), and Rubens. ${ }^{159}$ Of primary concern in this chapter are the works of Bruegel, van de Velde, and Teniers. It was Bruegel's exploration of genre themes that was translated through his students. Van de Velde was a student of Vinckboons, and Vinckboons himself a student of Bruegel's. Teniers married one of Bruegel's granddaughters, Anna, with Rubens acting as a witness. Therefore, there was a family connection between Teniers and Bruegel.

\section{Garden Parties Reimagined}

Many Northern artists depicted scenes of gardens populated by fashionable men and women strolling around a highly-constructed landscape. In addition to paintings of people walking through gardens, artists such as van de Velde depicted people dining in garden settings as seen in The fête champêtre (figure 63). These paintings typically depicted a table around which the participants sat with a view of the carefully trimmed hedges surrounding them and a gazebo or other type of outdoor pavilion. Sometimes the landscape was less structured, the party simply taking place in a clearing surrounded by trees. These garden parties depict courtly elegance, the trappings of pleasure, and often

\footnotetext{
${ }^{159}$ Holmes, Nicolas Lancret: Dance Before a Fountain, 13-14.
} 
emphasize the drinking of wine. These are all elements that Lancret included in his own French version of garden parties.

The dating of the first outdoor feast scene discussed in this chapter, Le repas italien (figure 64), is up for debate. The painting was completed sometime before 1738, the year it was reproduced in print form. Upon its engraving, and before its appearance in the collection of Frederick the Great of Prussia in 1773, the painting was in the collection of the duc de Valentinois, Jacques-François-Léonor Goyon (1689-1751). ${ }^{160}$ Le repas italien serves as a bridge between Lancret's early imitation of Watteau and his later development of a more personal style. The painting combines Lancret's earlier delicate figures with more robust ones and adheres to Watteau's outdoor scenes, while incorporating a stronger color palette. The composition remains fairly crowded and the figures occupy the middleground of the painting.

Le repas Italien consists of a group of men and women in a landscape. The left two thirds of the painting are occupied by a party sitting around a low table draped in white cloth on which a basket of grapes, wine bottles, and half a loaf of bread are situated. At the left of the painting, a lutenist tunes his instrument while placing his foot on a basket of wine bottles, another empty bottle lays next to the table leg. A woman dressed in silver at the right front of the party is handed a glass of wine by a man holding a rattan-wrapped bottle. To the right of the painting, a woman on a swing is being swung by a man holding a rope attached to the swing while another lady reclines in the shade of the tree that supports the swing and helps to draw the viewer's eye to the right of the painting.

\footnotetext{
${ }^{160}$ Mercure de France vol. 2 (Paris: June 1738), 1398; The Mercure de France notes, upon the painting's engraving, that it is part of the collection of the duc de Valentinois in 1738.
} 
Recently this painting has been discussed with relation to the Italian theatre given that a darkly-clad figure of Scaramouche can be identified in the painting. He is seated directly behind the woman in the foreground being offered a glass of wine. Scaramouche is seated and has propped himself up on the knee of a reclining woman who wears a collar on her dress à l'espagnole. A number of other figures have been identified as wearing theatrical costume. ${ }^{161}$ In the inscription with the engraving after the painting by Le Bas the figures are described as "vêtus à l'Italienne" or dressed in Italian costume by the Mercure de France. ${ }^{162}$ This identification explains the title of the painting but still leaves open the question of its subject. Is this painting a depiction of an actual scene from a play, or is it a work of the artist's imagination? The answer to this question may lie in comparing this painting with the painting L'automne (fig. 12) discussed in Chapter One. Both paintings are from the early years of the artist's mature period and both depict commedia dell'arte figures in costume. As previously mentioned, Lancet would have been familiar with figures from the Italian theatre troupe through his apprenticeship with Claude Gillot and Watteau's paintings. Furthermore, the links between Lancret's L'automne and Watteau's Les fêtes vénitiennes has already been established.

Therefore, Le Repas Italien fits into the same developmental period in Lancret's career when he is still drawing inspiration from the elder artist in both subject matter and style but differentiating himself in iconography. Given this comparison, an earlier dating than 1738 is appropriate. The recent catalogue of German collections, Französische Gemälde I: Watteau, Pater, Lancret, LaJoüe, gives the date as „um 1720“ or around

\footnotetext{
${ }^{161}$ Mary Tavener Holmes, "Katalog: Nicolas Lancret," in Französische Gemälde I: Watteau, Pater, Lancret, Lajoüe, ed. Christoph Martin Vogtherr (Berlin: Akademie Verlag, 2011), 461-462, 465-466. ${ }^{162}$ Holmes, "Katalog: Nicolas Lancret," 465.
} 
$1720 .{ }^{163}$ This dating seems appropriate given that ,um $1720^{\circ}$ would place the painting at a date in accordance with the dating of L'automne to 1721-23. In Le Repas Italien Lancret depicts a well-known figure from the theatre, uses compositional elements seen in Watteau's paintings, but renders his figures with a little more weight and individualism while incorporating them into an event not depicted previously. Hence, the painting is not necessarily about the commedia dell'arte, despite the title of the painting telling the viewer so; rather it is about the convivial party and their participation in an outdoor meal. The text included with the engraving reiterates this conclusion:

In this charming place where there are so many beautiful women, whose air is too gallant, so that they may be cruel, nothing can prevent, Mercy, your happiness: If love fills you with the tenderest ardor; In concert with this, Bacchus with his liqueur was able to put you in a position to dare to undertake anything. ${ }^{164}$

The passage indicates that the subject of this painting is not about the theatre but about the merry-making and amorous intentions of the participants. In this way Le Repas Italien reflects the influence of van de Velde, whose paintings depict similar scenes of dining garden parties and merrymaking companies. Supporting the link between Lancret's painting and the Northern tradition is the Mercure's further characterization that a collector wanting copy of this print would easily be able to integrate it into his or her collection between les Réjoüissances Flamandes and la Fête de Village also engraved by Le Bas. ${ }^{165}$

\footnotetext{
${ }^{163}$ Holmes, "Katalog: Nicolas Lancret," 460.

${ }^{164}$ Mercure de France vol. 2 (1738), 1398-1399 ; «Repas ltalien Dédié à son Altesse Monseigneur Honore Grimaldi par la grace de Dieu Prince de Monaco à Paris chez J. P. LeBas graveur. Dans ce charmant séjour, où brillent tant de Belles, Dont l'air est trop gallant, pour qu'elles soient cruelles, Rien ne peut empêcher, Amans, votre bonheur : Si l'Amour vous remplit de l'ardeur la plus tender ; De concert avec lui, Bacchus par sa Liqueur Sçait vous mettre en état d'oser tout entreprendre. M. Moraine. Gravé d'après un tableau original de Lancret, haut de 3 pieds 1 pouce sur 4 pieds 1 pouce de large, du Cabinet du duc de Valentinois. »

${ }^{165}$ Mercure de France vol. 2 (1738), 1399.
} 
Van de Velde (figure 63) is credited with the development and popularization of the new garden party genre which combined upper-class leisure with park-like settings. ${ }^{166}$ Though, as scholar Larry Silver has noted, the “"merry companies,' which are only nascent within Bruegel's own oeuvre, emerge quickly and fully... into the newer form of gardens and the biblical scenes of indulgence and temptation take on a contemporary cast of characters," as seen in van de Velde's paintings. ${ }^{167}$ As with paintings by van de Velde, Lancret does not depict the actual meal taking place, but rather the remnants of the meal still remain.

In addition to the figure of Scaramouche in Le Repas Italien, the image of a woman swinging is one that Lancret would have acquired through his knowledge of Watteau's works and his training with Claude Gillot. The subject appears in Gillot and Watteau's interior room decorations. Lancret had previously depicted this leisure time activity in a series of five decorative panels from the mid- to late-1720s now in the Cleveland Museum of Art. The compositional arrangement of the figures in Le Repas Italien is practically a mirror image of those in The Swing panel (figure 65). Additional paintings by Lancret of the same subject abound. More often than not, scenes of swinging in Rococo paintings are amorous in intent, further explicating the subject of Le Repas Italien. The subject of the swing as amorous encounter was most famously depicted by a later Rococo artist, Jean-Honoré Fragonard (1732-1806).

Le Repas Italien should be dated securely to the early 1720 s and is indicative of Lancret's early emulation of Watteau. The size of the figures in relation to the landscape,

\footnotetext{
${ }^{166}$ Larry Silver, Peasant Scenes and Landscapes (Philadelphia: University of Pennsylvania Press, 2006), 179-80.

${ }^{167}$ Silver, Peasant Scenes and Landscapes, 184.
} 
the inclusion of commedia dell'arte figures, the use of theatrical costumes, and the common arabesque element of the swing all reinforce this idea. The theatrical figures and dress is reminiscent of Lancret's earlier work L'automne. Holmes aptly notes that the name of the painting "is to be read only as an indication of a reference of the scene or the persons to the theater" as opposed to indicating that an actual Italian-inspired meal was consumed. ${ }^{168}$ However, the combination of the figures, the dining scene, and the swing are original to Lancret. The influence of Northern garden parties, such as those by van de Velde, is evident in the composition of the work. As with many of Lancret's early paintings that contain food items, the artist has simply depicted wine and grapes; in this instance it is not the meal that is important but rather the sociability that the meal allowed.

Another dining scene that emphasizes sociability and displays the influence of Northern painters such as van de Velde is the slightly later work, Dance in a Garden (Danse dans un jardin) (figure 66). This painting is more characteristic of the artist's mature period and his stylistic developments in the increased scale of the figures in relation to the landscape. The setting of this painting is again a wooded area; however, in this instance a table and make-shift tent have been included. Five women and three men are arranged around the table in the middlegound with one of the men standing in the center of the painting and daintily holding a wine glass aloft. On the table a silver or porcelain bowl sits filled with peaches, and next to it an empty wine glass sits on its side. A couple is dancing in the left foreground while an old man playing a hurdy-gurdy is seated to the right. A young servant kneels in the central foreground with an empty wine

${ }^{168}$ Holmes, "Katalog: Nicolas Lancret," 466. 
bottle in one hand with his other reaching into a basket. A blue linen lies on the ground in front of the basket with two loaves of bread on top of it and two more empty wine bottles and a wine glass lie in the grass. ${ }^{169}$ Wildenstein's description of the work, which is based on the 1782 sale inventory of Madame Lancret, varies little from the one given above. ${ }^{170}$

The Ackland Art Museum currently dates the painting to the mid-1730s; however, a more appropriate date would be the late-1720s. The handling of the figures is more reminiscent of Le repas italien or Le repas au retour de chasse than Lancret's paintings from the following decade. While they are larger in relation to the background, the costumes of the male figures particularly reveal the lingering influence of Watteau and theatrical dress. Much like Le repas italien, the act of sociability takes precedence over the act of dining. The only foodstuff depicted is the peaches, bread, and wine.

La danse dans le parc (figure 67) is very similar to Dance in a Garden and should be dated to the same time or slightly before, based on the figural style. The current whereabouts of the painting are unknown, but the painting was sold at auction by Sotheby's in 2015. The sale catalogue listed the title of the work as Fête Champêtre with a Dancing Couple. ${ }^{171}$ The title La danse dans le parc comes from Wildenstein's monograph on Lancret, where he described it as follows:

In the foreground, on the left, a couple dances to the sounds of the musette held by a musician sitting in the middle of the canvas. On the right, at the foot of a wall, partly

\footnotetext{
169 "The Feast in Film, Philosophy, and Fiction: A Virtual Gallery of Images from the Ackland Art Museum," Ackland Art Museum, University of North Carolina at Chapel Hill, last modified Fall 2010, http://feast.web.unc.edu/lancret/

${ }^{170}$ Wildenstein, Lancret, $82, \mathrm{Nr} 169$; «Un jardin ; trois hommes...en habit de caractère et cinq femmes assises proche une table, un home et une femme dansent, un vieillard assis joue de la Vielle, un garçon tient une bouteille et prend quelque chose dans un panier. Tableau clair... »; The painting was not sold during Lancret's lifetime and only appears in the sale of Madame Lancret after the artist's death. It has apparently passed through numerous private collections before coming to the Ackland Art Museum at The University of North Carolina, Chapel Hill. As such, little scholarship exists on the painting at present.

171 "lancret, nicolas fête ||| genre scene ||| sotheby's 115318lot78bpqen, April 28, 2015" Sotheby's Auctions, accessed 2018, . http://www.sothebys.com/en/auctions/ecatalogue/2015/mansion-overlooking-royal-park115318/lot.63.html
} 
hidden by foliage, a table on which are placed fruits, bread, etc. Around [the table], five people: a man standing, who fills his glass, two women seated, that clink [their glasses], a woman who brings a basket, another woman who looks at the dancers. In front of the table [are] two dogs and a basket containing bottles. ${ }^{172}$

Two more empty bottles lie next to the dog in the foreground. Again, the foodstuff is limited to peaches, grapes, bread, and wine. Curiously, the woman described as bringing a basket seems to be clearing it from the table and the basket is not a basket but a bowl. Even more curious is the contents of the bowl, a white fluff. While the substance could be interpreted as a white linen covering the contents of the bowl, the implied texture of the item does not match the same texture with which the actual linens on the table are depicted. The white fluff may be a meringue which was eaten for dessert as described in François Massialot's 1692 Nouvelle Instruction pour les Confitures, les liqueurs, et les fruits; however, the painting lacks any utensils which with the meringue would be eaten and the cave necessary for its transportation. ${ }^{173}$ Furthermore, grapes and meringue is an odd pairing and the whole peaches depicted are not suitable for either dipping into or scooping the substance, yet these details may not have been important to the eighteenthcentury viewer of the painting. The mere presence of the meringue and fruit, the dress of the figures, and the leisure time activity depicted would have been enough to impart the air of elite fashionablity and sociability that was important to the viewer.

Holmes has suggested from the tilt of the composition and the dominant figures that this painting was originally part of an overdoor. ${ }^{174}$ While this is an interesting

\footnotetext{
172 Wildenstein, Lancret, 84 ; « Au premier plan, à gauche, un couple danse aux sons de la musette que tient un musicien assis à peu près au milieu de la toile. À droite, au pied d'un mur, en partie caché par des feuillages, une table sur laquelle sont placés des fruits, du pain, etc. Autour, cinq personnages : un homme debout, qui remplit son verre, deux femmes assisses, que trinquent, une femme qui apporte une corbeille, une autre femme qui regarde les danseurs. Devant la table deux chiens et un panier contenant des bouteilles. »

${ }^{173}$ François Massialot, Nouvelle Instruction pour les Confitures, les liqueurs, et les fruits (Paris : Chez Saugrain, 1760) 207-209.

174 "lancret, nicolas fête"
} 
suggestion, the tilt of the landscape is similar to that of Le repas au retour de la chasse which was not an overdoor. However, the less-defined features of dancing woman in pink would allow for the painting to be seen from a higher distance. Regardless of the veracity of this assessment, the paintings La danse dans le parc, and Dance in a Garden, serve as an important transitional period in Lancret's artistic development. While he was still reliant on Watteau for aspects such as theatrical dress and leisure time subjects, he was also looking at Northern dining scenes and incorporating elements from this genre into his own works.

\section{Peasant Festivals Reimagined}

In addition to garden parties, another major genre in Northern paintings was that of the peasant festival. Sometimes these images included the entire town and were village fêtes; sometimes the festivals revolved around religious holidays. While Breugel is wellknown for his paintings of peasant festivals, in this instance Lancret's works have more in common with the paintings of Teniers, a painter he is known to have admired.

Most emblematic of the influence of Northern Renaissance and Baroque paintings on Lancret's oeuvre are two paintings titled Le Repas de Noce au Village and The Wedding Breakfast (figure 6 and 7). Both paintings have obvious affinities to paintings by Watteau, but even more than that it is quite clear that Lancret was looking past Watteau's interpretation of Northern paintings to the Northern paintings themselves.

The version of Le Repas de Noce au Village (1735) (figure 6) at the Musée d'Angers is thought to be an oil sketch, or esquisse, for a commission for Louis XV's first salle à manger at Fontainebleau. This small private dining room was installed on the ground floor of the king's grands appartements in 1736 as a place for Louis and his 
hunting companions to relax after their hunting excursions. ${ }^{175}$ While the finalized version is now lost, the painting was shown at the 1737 Salon; however, the entry in the Mercure de France regarding the paintings gives very little information, simply noting the name of the painting as Festin de Noces de Village. ${ }^{176}$ Lancret's final version of this work was presumably one of five paintings that decorated the space and was installed over the buffet. The final painting would have been surrounded by a boiserie framework. ${ }^{177}$ Fernand Engerand's 1899 l'Inventaire des tableaux nouvellement faits pour le service du Roy pendant l'année 1737 describes the work as "the priest, at a table with the young bride, seems to give her instructions; Charpentier, excellent musette [player], at the corner of the table playing his instrument so a shepherd and shepherdess can dance, in the background a landscape." ${ }^{178}$ It was one of three paintings that Lancret supplied for Fontainebleau, the other two depicting more dancing shepherds and shepherdesses. ${ }^{179}$

\footnotetext{
${ }^{175}$ Vincent Droguet, Louis XV à Fontainebleau (Paris: Réunions des musées nationaux, 2016), 161, 165; for a discussion of the decoration of the second, larger salle à manger at Fontainebleau see Williams, "Dining and Revelry in French Rococo Art."

${ }^{176}$ L'Academie Royale, Explication des peintures, sculptures, et autres ouvrages de messieurs de l'Académie royale (Paris : Jacques Collombat, 1737), 12 ; « cintré haut et bas »; See Wildenstein, Lancret, 103 , no. 516.

177 Droguet, Louis XV À Fontainebleau, 165.

${ }^{178}$ Fernand Engerand, Inventaire des tableaux commandés et achetés par la Direction des Bâtiments du Roi (1709-1792) (Paris : E. Leroux, 1900), 266 ; « le curé, à table avec la jeune mariée, semble luy donner les leçons ; Charpentier, excellente musette, au coin de la table joüe de son instrument pour faire danser un berger et une bergère, sur un fond de paysage ; ayant de hauteur 7 pieds un pouce sur 5 pieds un pouce; cintré haut et bas. »

${ }^{179}$ Engerand, Inventaire des tableaux, 266-67 ; the other two paintings depict « un Concert de bergers et de bergères gardant leurs coutons, un berger, dans le fond, paroist tenir une bergère en jouant de la flute ; une fontaine et du paysage ; ayant de hauteur 2 pieds 7 pouces sur 2 pieds 9 pouces ; cintré haut et bas. » and « une Danse de bergers et bergères, un berger joue du tambourin, mêmes forme et mesure que le précédent ; sur un fond de paysage. »; For all three "Festes de village" Lancret was paid 4,222 livres ; Engerand notes the final painting's dimensions as 2'7' by 2'9" in comparison to the oil sketch at Angers which measures 1'4" by 1'1", See : Engerand, Inventaire des tableaux, 266 ; « ayant de hauteur 7 pieds un pouce sur 5 pieds un pouce ; cintré haut et bas. »; «Collections en ligne : Les musées d'Angers : Un festin de noces de villages, » Les musées d'Angers, http://musees.angers.fr/collections/collections-en-

ligne/index.html
} 
The painting in Angers depicts a festive outdoor scene commensurate with Engerand's description of a table that is surrounded by seated and standing party members. Trees screen the painting to the left, while a rustic building frames the group on the right. The faces and comportment of the figures are all typical of Lancret's style. To the left of the table musicians play for dancing couple in the right foreground. A central man in a yellow jacket raises his glass which appears to be filled with white wine. Other wine glasses are scattered along the table and are filled with red wine, while the dancing man in the foreground holds a rattan-wrapped bottle aloft. Dogs in the left foreground devour remnants of the feast, a sliver of which is visible on one of the silver plates strewn on the ground. On the table, only small hints of the meal remain - a plate on the left corner of the table appears to hold a slice of pink cake or pastry and a plate of rolls or, more likely peaches, sits at the very right. Given that this painting was a sketch, it is not surprising that the work is not as finely detailed, or the details as carefully delineated as Lancret's other paintings. As is typical with his oil sketch method, the details are suggested through color and its relative placement.

Both the Musée d'Angers' website and 2004 printed catalogue note the subject of the painting as Flemish in origin. ${ }^{180}$ However, the printed catalogue further remarks on the influence of Bruegel or Rubens on the paintings of the artist and calls the scene depicted an "une improbable Arcadie" indicating the fantastical nature of the painting.

\footnotetext{
180 «Collections en ligne : Les musées de Angers : Un festin de noces de villages, »; According to the Museum's website: « Si le peintre est français, le sujet de cette œuvre, une noce de village, est d'origine flamande. L'influence nordique est confirmée par quelques détails truculents au sein de la joyeuse assemblée : les chiens dévorant les restes du banquet, la femme repoussant un galant trop empressé, la gesticulation des danseurs. La noce se déroule probablement en Île-de-France. D'une touche légère au coloris clair, l'artiste restitue un cadre champêtre mêlant arbres verdoyants, bâtisses rustiques et animaux. Cet écrin naturel renforce l'atmosphère vivante et paysanne de la fête. »; Musée des Beaux-Arts d'Angers, Chef-d'oeuvre du musée des Beaux-Arts d'Angers (Paris : Somogy éditions d'art, 2004), 120.
} 
Furthermore, the catalogue notes that the finished painting is the artist's first treatment of the theme of a festival or a noce, a French term indicating a wedding or wedding feast.

The companion painting to the Angers' oil sketch of Le Repas de Noce au Village, Une danse champêtre (figure 68), was presumably commissioned around 1740 as a pendant upon the acquisition of the oil sketch. ${ }^{181}$ The sketch for the Fontainebleau commission found its way into the collection of Ange Laurent de La Live de Jully, who had also acquired the companion painting, and it was sold in 1770 to the artist Jean-Denis Lempereur (1726-1796). Both paintings were then sold to Louis François de Bourbon (1717-1776), prince de Conti, a great-grandson of Louis XIV and cousin of Louis XV, in 1773; Pierre-Louis Eveillard (1736-1790), Marquis of Livois acquired the two paintings after the death of the prince in 1777. Along with most of Eveillard's collection, the paintings passed to the city of Angers after they were seized during the French Revolution in $1799 .{ }^{182}$ Une danse is similar to Le Repas with regard to style and dimensions of the canvas. However, the figures in Une dance are larger in relation to the landscape than those of its companion. Une dance depicts the young married couple at the center of the painting presumably about to start or having just finished dancing. A man playing a violin can be seen just over the left shoulder of the groom. The church where the ceremony presumably took place dominates the background. The church in the

\footnotetext{
${ }^{181}$ Musée des Beaux-Arts d'Angers, Chef-d'oeuvre, 120-121; The works were apparently painted on two very different types of canvas.

182 «Collections en ligne : Les musées d'Angers : Une danse champêtre, » Les musées d'Angers https://ow-mba.angers.fr/ow4/mba18022013/voir.xsp?id=00101-251\&qid=sdx_q1\&n=3\&e= «Collections en ligne : Les musées d'Angers : Un festin de noces de villages »; Musée des Beaux-Arts de Valenciennes, Watteau et la fête galante (Paris: Éditions de la Réunion des musées nationaux, 2004), 146.
} 
background is "clairement l'architecture francilienne," indicating that this particular set of paintings is meant to depict the area around Paris, the Île-de-France. ${ }^{183}$

However, the assumption that the couple are dancing may be misleading. The exhibition catalogue Watteau et la fête galante claims that the young groom is proffering his hand to his bride to lead her to the altar. ${ }^{184}$ The catalogue titles this painting as Le Cortège de fiançailles or The Engagement Procession. Evidence for this reevaluation of the subject matter includes the description of the painting in the sale by Lempereur as "a village bride who is going to the church." ${ }^{185}$ At the prince de Conti's sale, the painting was referred to as The Dance of the Bride, but in Wildenstein's monograph on the artist, it was called La Danse au Village. Several variants on the name have been used, including La Danse de noces, Le Cortège de fiançailles, and its current title on the Musée d'Angers' website, Une danse champêtre. However, with the identification of the subject matter as that of Le Cortège de fiançailles a number of parallels can be drawn. First, one can compare it to Watteau and his numerous paintings dealing with marriage, La Mariée de Village (figure 60) and Accordée de Village (figure 61), and a drawing, Le Cortège de fiançailles (figure 69), whose characters are figures from the commedia dell'arte. ${ }^{186}$ In this instance Lancret has eliminated the theatre costumes in favor of the rustic ideals of Northern genre paintings.

\footnotetext{
183 This statement is made by both the museum's website and the printed catalogue : «Collections en ligne : Les musées d'Angers : Un festin de noces de villages »; Musée des Beaux-Arts d'Angers, Chefd'oeuvre, 120-21.

${ }^{184}$ Musée des Beaux-Arts de Valenciennes, Watteau et la fête galante, 146. « Les protagonistes de cette œuvre de Lancret peuvent certes donner l'impression d'être en train d'exécuter un élégant pas de danse, mais ce n'est pas le cas : le jeune marié offre sa main à la mariée pour la guider jusqu'à l'autel. »

${ }^{185}$ Musée des Beaux-Arts de Valenciennes, Watteau et la fête galante, 146 ; « une mariée de village qui va à l'église. »

${ }^{186}$ Musée des Beaux-Arts de Valenciennes, Watteau et la fête galante, 147.
} 
The painting The Wedding Breakfast (1737-40) (figure 7), and its companion in the collection of Waddesdon Manor (figure 70), do not appear in Wildenstein's monograph despite his careful cataloguing of other paintings by the artist in various collections of the Rothschild family. ${ }^{187}$ The Wedding Breakfast appears to be Lancret's third and final treatment of the subject of the village wedding. The composition of the painting varies slightly from the oil sketch at Angers. The trees and building framing the wedding party have been reversed, and a cloth has been hung from trees to create a tent. The dogs in the foreground have been replaced by a seated party on the right; a couple is dancing between a standing group of figures to the left of the table and the violin players. The figure of the priest is gone, and the bride, while still remaining the central figure, has been pushed towards the background further and almost appears to be seated on the knee of the groom. As with the Angers version, empty and full wine glasses and bottles can be seen on the table with a bottle on the ground between the legs of a seated man who mimics the pose of the participants in Lancret's Le dèjeuner de Jambon. Again, remnants of the meal remain on the table with the plates appearing to hold a piece of meat, another a chunk of bread, and the same plate of peaches at the right.

\footnotetext{
${ }^{187}$ Wildenstein, Lancret, 77, 103; The painting and its companion are not mentioned under the heading "Scenes Villageoises" which is where the Angers paintings are discussed; two other works are listed under the heading "Le Repas" as Le Repos champétre and Le Goûter champétre but the dimensions of the paintings do not match the Waddesdon paintings, nor does the title Le Repos champétre properly describe the companion work, The Village Wedding. "The Wedding Breakfast - Waddesdon Manor," Waddesdon Manor, https://waddesdon.org.uk/the-collection/item/?id=8606; The Waddesdon Manor publications and website refer to the painting as The Wedding Breakfast as opposed to The Wedding Feast but the website notes the French title as Le repas de noces de village. According to the Manor's website: "They were probably not originally painted together. This painting has added strips of wood to make it bigger, visible at the upper and right-hand edges. These were added after the painting was made probably to match the size of the other panel. However, the style of painting on the extra strips looks very similar to the main panel and may well have been painted by Lancret. They may have been added after a patron acquired both the village wedding and this painting and wanted to make them the same size so they could be displayed together."
} 
This painting appears to be from Lancret's later, mature period as the figures are larger in comparison to the background, and they are depicted with more courtliness and ease. Still, the influence of Watteau can be noted in some of the poses of the figures, such as the girl at the far right of the table with her hands to her breast. The Waddesdon Manor website suggests that the musicians and dancers depicted by Lancret in this work are professionals as opposed the peasants depicted in the Angers paintings. ${ }^{188}$

The Village Wedding (figure 70), the pendant to The Wedding Breakfast, depicts a young woman being led towards her new husband who holds the reins of a waiting donkey. The nondescript courtyard from which the party has emerged may belong to a church, though the only indication of this is a tower with gothic windows in the center background of the painting. Unlike the Musée d'Angers' website and catalogue mention of Lancret's “improbable Arcadie," the Waddesdon Manor's website describes their paintings by Lancret as being "set in an unidealized, convincing landscape are all reminiscent of Teniers's paintings." 189 The Manor further identifies the man, woman, and child at the left of the work, the man with the donkey in the foreground, and the rather unidentifiable building as characteristic of Northern paintings. ${ }^{190}$ Advancing the ties to Northern precedents is the previous argument that the Angers' companion painting should more correctly be referred to as Le Cortège de fiançailles (de village) or Le Cortège de noce. The reidentification of both companion paintings to Le Cortège de noce better identifies the subject matter of the scene and makes the two sets of paintings more cohesive.

\footnotetext{
188 "The Wedding Breakfast - Waddesdon Manor"

189 “The Village Wedding - Waddesdon Manor,” Waddesdon Manor, https://waddesdon.org.uk/thecollection/item/?id=475

190 "The Village Wedding - Waddesdon Manor"
} 
Both the painting in Angers and the painting at Waddesdon Manor that depict wedding feasts are in keeping with the conventions of the Northern tradition in which the food or the act of feasting is not the most prominent aspect of the works. Not a single person is actively shown eating, but the meal is suggested by the remnants of food and bread on the platters, table cloth, and ground. Additionally, Lancret includes the dogs in the foreground, a motif he had utilized previously in Le dèjeuner de Jambon and one which can also be found in the early German prints of Bedham and his followers. Other details betray Northern influences on this painting: the musette, or bagpipe, player whose instrument is decorated with floral garlands; the man to the left of the bagpiper who plays a reed-instrument; and the modest gesture of the seated bride sitting next to the clergyman who has her hands crossed over her abdomen in the Angers version. ${ }^{191}$ The paintings of Bruegel's Peasant Kermis and Peasant Wedding Dance (figure 71 and 72) instantly spring to mind as the possible predecessors or inspiration for Lancret's paintings despite their differences. Scholar Gillian Riley has noted that Bruegel's paintings “often consisted of a series of four of five scenes showing different stages in the Peasant Wedding - from the procession of the bride and groom to the church to the nitty gritty of dowries... One aspect of these village fêtes is the wedding feast."192 Both paintings by Lancret now have companion paintings which may or may not have been originally intended as such; if not, however, by pairing the two paintings with another also depicting an aspect of matrimonial rituals, the painter or the collector would have been acknowledging a common convention of paintings within this theme.

\footnotetext{
${ }^{191}$ Stewart, Before Bruegel, 190, 194-6.

192 Gillian Riley "Lust, fear, and loathing on the Village Green" in The Oxford Symposium on Food and Cookery: The Meal 2001 ed. Harlan Walker (London, Prospect Books, 2002), 201-202
} 
As with the paintings by Bruegel, the setting for all four of Lancret's paintings are bucolic landscapes; but while the landscape is rustic, the participants are not. Lancret's brides, grooms, and the wedding parties are obviously not of the Northern peasant type. The majority of them are wearing elegant eighteenth-century costumes despite their various states of dishevelment. While it is unclear what paintings by Bruegel Lancret may have had access to, Bruegel's peasant scenes were widely available in print form and very popular. Though Lancret owned a painting by the Northern artist it was a religious work. Scholars have also noted that paintings from the north were routinely promoted by Paris-based dealers who reshaped French fashions with regards to the collecting of Netherlandish paintings. ${ }^{193}$

However, unlike Beham's early German prints, Lancret eliminated any references to excessive eating and drinking and the bodily functions that result from these excesses. While the peasants in Bruegel's paintings also appear to be cleaner than those depicted in the German prints, he still included some scatological details, and his figures are often noticeably intoxicated. Lancret's two versions of the wedding feast may have been influenced by Teniers's later depictions which temper the carnal nature of the genre. Teniers often depicts musicians playing the bagpipes, but he also includes a lutenist in numerous paintings similar to the pair of musicians depicted in the Angers' version. The sexual nature of the paintings by Lancret is not explicit; however, it is a more tongue-incheek humor that is seen in a number of Lancret's paintings. The juxtaposition of the musette with that of the lute is sexually suggestive. Musettes are feminine in nature, a hollow vessel that was meant to be filled; the feminine aspect of the instrument is

${ }^{193}$ De Marchi and Van Miegroet, "How Netherlandish paintings came to Paris," 29-30. 
accentuated even more so with the floral garland decorating it in the painting. ${ }^{194}$

Furthermore, the musette contained connotations of an idyllic countryside suitable for lovers. ${ }^{195}$ The lute has obvious phallic connotations as previously discussed in Chapter One. The inclusion of these instruments in a wedding feast is perhaps a foreshadowing of the bride and groom's first night together. The combination of these two instruments is not common throughout paintings by Lancret. They are, however, found in the more ribald Northern versions of peasant and wedding scenes.

\section{La Muette series of the Seasons}

Along with depictions of wedding or village feasting scenes, another example of Lancret's borrowing and adaptation of Northern subjects can be seen in his paintings of the seasons. These series were often another excuse to represent amorous dalliances as they had been in the Northern tradition. ${ }^{196}$ While the Northern paintings typically combined both the labors of the seasons and months with amorous couples, Lancret almost completely rids his paintings of laborious aspects to focus on the leisure activities of the participants.

In 1738, Lancret completed another royal commission for a series of the seasons for the château at La Muette (figure 73-76). This series, now in the Louvre, begins with the depiction of Spring (Le printemps) (figure 73) that includes a group of women watching birds being caught; Summer (L'été) (figure 74) consists of two men cutting hay

\footnotetext{
${ }^{194}$ Colin Bailey has argued that cabbages represent fecundity in the paintings by Francois Boucher. See: Bailey, “"Details that surreptitiously explain”: Boucher as a Genre Painter.” Furthermore, overturned vessels and pots in rustic genre scenes have been interpreted as empty vessels yet to be filled in relation to the amorous nature of the scene at hand. This idea is carried further here with the instance of the instrument.

${ }^{195}$ Grasselli, Rosenberg, and Parmantier, Watteau: 1684-1721, 539.

${ }^{196}$ Banks, Watteau and the north, 164.
} 
with a group of women and men holding hands in a circle, while Autumn (L'automne) (figure 75) depicts a party picnicking;. Finally, Winter (L'hiver) (figure 76) is represented by a group of men and women ice skating on a frozen-over fountain. Though while Bruegel and his followers included leisure activities alongside seasonal labors in their paintings of the seasons, Lancret emphasizes the leisure activities and downplays the labors. When labor is shown, it is a form of play much like that of elite pleasure dairies which were places where ideas of honnêteté were maintained. These images further the associations of a rural, rustic ideal and emerging ideas about women, nature, the body, and health. ${ }^{197}$

The painting L'automne (figure 75) depicts a group of men and women seated on a knoll in the forefront of the image. The placement of the figures within the landscape and around the cloth spread on the ground is reminiscent of Lancret's Le repas au retour de chasse while the distant view into the landscape at the left resembles Le déjeuner dans le foret. The figures conform to Lancret's mature style characterized by more robust, as opposed to waifish, figures and their unique heavily-lidded eyes. In this painting, two women and a man sit on the ground around a spread-out linen with a basket by the man's feet; a man stands alongside a donkey loaded with a basket at the left while a couple is seated to the right of the painting. The seated man raises a glass of red wine and looks at the woman who holds a basket propped on her thigh, while another basket laden with grapes is at her feet. Next to her, a larger basket similar to the one harnessed to the donkey lies on its side. The standing figure of a woman also holds a basket behind the central-most seated woman. The meal spread before the party appears to be made up of

\footnotetext{
${ }^{197}$ For more information see: Meredith Martin, Dairy Queens: The Politics of Pastoral Architecture from Catherine de' Medici to Marie-Antoinette (Cambridge, MA: Harvard University Press, 2011).
} 
bread, wine, and a meat pie. Visible between the legs of the donkey to the left are four women and a man holding a basket. Two men, one with a basket mounted on his back, and a woman can be seen behind the donkey at the very edge of the painting.

Once again, Lancret has removed almost all allegorical or mythological references. The only way to identify this painting as that of Autumn is due to the inclusion of grapes in a basket at the lower right corner of the painting. Unlike the other seasonal paintings, this one shows the laborers who have been gathering grapes in the fields. The women are very plainly dressed compared to their counterparts in the Spring and Winter paintings and a basket similar to the one worn by the man in the background next to the seated woman at the right. These baskets that are worn on the back are depicted in Northern works, such as Jan van de Velde's (1593-1641) September (figure 77) etching. ${ }^{198}$ While van de Velde's work clearly separates the high society, depicted in the foreground on a small hill, from the working man seen carrying his basket down the road, Lancret fuses the two social classes into a romanticized bucolic representation of labor. So his figures would not be confused for commoners, Lancret depicts them eating from well-polished silver plates and wine and water glasses as opposed to lesser metal platters or earthenwares. A silver chilling bucket also sits at the center of the tablecloth. The men wear tricorn hats and contemporary costumes; while the women are dressed plainly they are still very neat and quite fashionable.

As previously discussed in Chapter One, Lancret differed from Watteau in his depiction of the seasons. Lancret utilized subtle details to help with the identification of the seasons in the earlier series completed for Jean-François Lériget de La Faye. In a

${ }^{198}$ Gibson, Pleasant Places, 122. 
manner similar to the Lériget series, Lancret has stripped this series of all allegorical or mythological references to classical antiquity. It is only through knowledge of the Northern traditions of representing such series that each season can be identified. It is again Bruegel that best exemplifies this these types of series. Bruegel's series of The Months (figure 78-80) depicts the various agricultural activities that go along with the changing seasons, though he does include some leisure activities as well. ${ }^{199}$ Bruegel's spring panel (now lost) would possibly have depicted images of courtly love and flowers. ${ }^{200}$ Wheat Harvest (figure 78) is meant to represent summer and includes figures resting and eating, napping, and even swimming in the distant background. Return of the Herd (figure 79) represents autumn and depicts grape harvesting, a traditional seasonal event previously discussed in Chapter Two. Undoubtedly, the most famous painting of this series, Hunters in the Snow (figure 80), depicts hunters returning after their meagre excursion and people playing on frozen-over lakes. As opposed to Bruegel's emphasis on the seasonal labors, these leisure activities are the focus of Lancret's paintings.

Lancret was also familiar with prints by his fellow countryman, Jan Mariette. Holmes references the borrowing by Lancret of various elements Mariette included in his prints. Though Lancret alters the context slightly, his image of Fire (figure 81) from a series on the elements very clearly invokes Mariette's series of the season, specifically that of Summer: St. John's Fire (figure 82). Lancret then utilized the same circle of dancers in the summer scene for the La Muette series; despite removing the fire around

\footnotetext{
${ }^{199}$ See Silver, Peasant Scenes and Landscapes, 123. While only five extant paintings from this series are known, scholars speculate that it originally consisted of six, rather than twelve, paintings with each painting representing two months.

${ }^{200}$ Silver, Peasant Scenes and Landscapes, 123 and Nicholas Ryan Erker, "Pieter Bruegel the Elder's The Months: A Perspective" (Order No. 1589429, University of Missouri - Kansas City, 2015), http://proxy.mul.missouri.edu/login?url=https://search-proquestcom.proxy.mul.missouri.edu/docview/1691799525?accountid=14576, 27, 40.
} 
which the figures dance, the amorous connotations of this summer festival are still evident and would have been obvious to the eighteenth-century viewer. ${ }^{201}$ The La Muette series is an excellent example of Lancret's ability to fuse contemporary French society and seventeenth-century print culture with Northern traditions of genre paintings.

As with a number of previous paintings by Lancret, the country and country life are idealized and romanticized, as they were in the minds of the artistocracy. So, while the dress of the figures is not as fashionable as those depicted in Dance in a Garden or La danse dans le parc they are more reminiscent of the rural costumes of Lancret's village feast and wedding scenes. While the dress of the figures in the La Muette series may be humbler in nature, given the status of the series as a royal commission it is most likely that the paintings were meant to depict idyllic labor as opposed to actual labor. Images such as these were focused on "wjio'work' centered less on production and more on consumption, royal symbolism, and aristocratic display." ${ }^{202}$ Meredith Martin has suggested that these images of work offer the aristocracy a way to solidify their authority and alleviate anxieties about the encroaching bourgeoisie during a time in which the upper class felt threatened. ${ }^{203}$ In this way they adhere to the imagined gaiety, goodness, abundance, and industry as mentioned in the quote that opened this chapter.

Even before Antoine Coypel's 1720 address to the academy, Northern paintings had been popular among collectors in Paris. Lancret was influenced by a wide variety of Northern genre scenes and incorporated their subject matter into his own contemporary French images. He dabbled in a range of Northern genres - from the lowly kitchen

\footnotetext{
${ }^{201}$ Holmes, Nicolas Lancret: 1690-1743, 16.

${ }^{202}$ Martin, Dairy Queens, 4.

${ }^{203}$ Martin, Dairy Queens, 7-8.
} 
scenes, to elite garden parties, peasant festivals, and various series of the seasons or months. Lancret's oeuvre exemplifies the extent to which Northern works were modified and assimilated into a French idiom during the eighteenth century. This does not mean that Lancret blindly followed a formulaic repetition of Northern works; he imbued his paintings with details and ideals that were central to French identity and its unique social distinctions, all the while exhibiting the playful nature characteristic of the Rococo period. One aspect of French identity was the consumption of food items and the developing notions of French superiority and culinary identity. Coffee, tea, and chocolate were new fashionable hot beverages that were used by the aristocracy to set themselves apart from the rising bourgeoisie. These beverages were incorporated into genre paintings to further these ends, and they are discussed in the following chapter. 


\section{Chapter Three - Lancret's Iconography of Hot Beverages}

\section{Overview}

As common as coffee, tea, and hot chocolate seem today, these now-ubiquitous beverages were the purview of the elite class during the eighteenth century. Despite their introduction into European society in the seventeenth century, the prohibitive cost of importation kept them in the realm of luxury goods. As such, they were social markers, and it is no coincidence that their appearance in genre paintings and aristocratic portraits are tied to depictions of aristocratic social pastimes and self-representation. Rose-Marie Herda-Mousseaux has noted that the artistic "representation of their [coffee, tea, and chocolate's] consumption coincides with a ritualization of this practice during meals; the scenes chosen by the artists relate essentially to two meals of the day: breakfast and a repast or intermediate snack between dinner and supper." ${ }^{204}$ Lancret incorporated these new fashionable beverages into the morning rituals of the toilette and the hunt as well as scenes of proper aristocratic education.

This chapter argues that Nicolas Lancret imbued the fashionable hot beverages of coffee, tea, and chocolate with metaphorical or allusionary meanings when he depicted them in his paintings. While the three beverages depicted in the paintings may not be readily identifiable, this may not have mattered to an eighteenth-century audience. Rather, it was the associations of the hot beverages that were important, and the artist's

\footnotetext{
${ }^{204}$ Rose-Marie Herda-Mousseaux, « Thé, café ou chocolat? » In Thé, Café ou Chocolat ? Les Boissons Exotiques à Paris au XVIIIe Siècle, Musée Cognacq-Jay (Paris : Paris Musées, 2015), 20 ; « la représentation de leur consommation coïncide avec une ritualisation de cette pratique durant les repas; les scènes retenues par les artistes se rapportent essentiellement aux deux repas de la journée : le déjeuner matinal et la collation ou goûter intermédiaire entre le diner et le souper. »
} 
use of them was imperative to the subject of the paintings. In all instances to be considered in this chapter, the beverages are key components of the paintings, as are the painted food items discussed in the following chapter. Without the beverages and their accompanying service items, the paintings by Lancret included in this chapter would not have as clear a narrative for either an eighteenth-century viewer or a modern one.

First is an examination of how and why these fashionable beverages came to be included in French paintings during the eighteenth century, briefly considering the social conditions that allowed their uses and depictions. Second, the history of the beverages is included since they were relatively new to European society in the eighteenth century, as well as an examination of their implied social connotations and the objects used in their consumption. Last is a discussion of the paintings, or groups of paintings, in which Lancret included a fashionable beverage; I have analyzed and interpreted these images by the type of beverage included by the artist.

Depictions of the mundane aspects of life in France during the eighteenth century were a common theme in the arts, both paint and print. These everyday activities were not commonly portrayed in the artistic productions of previous centuries. Possibly due in part to the lessening influence of the academy and the breakdown of the strict hierarchy of traditional subjects such as history painting, these new subjects came to demonstrate themes which previously would have been snubbed, and may seem unremarkable to some, even today. However, as recent scholarship has shown, these paintings of the everyday were more than just depictions of monotonous daily routines: they afforded the artist an opportunity to depict his figures, usually the fashionable elite, in carefully contrived poses meant to display their knowledge of contemporary social nuances or 
honnêteté and politesse. More than that, Melissa Hyde has demonstrated how depictions of Madame de Pompadour at her toilette, a daily routine of an elite aristocratic woman, can embody political and social meanings as well as dualities of artist/artistry. ${ }^{205}$

Many of the depictions of these daily routines can be characterized as tableaux de mode, or stylish pictures that were scrupulously painted that represent the lavish leisure activities of the aristocracy, allowing them to function as documents of fashionable customs and society in the eighteenth century. ${ }^{206}$ That is not to say, however, that these paintings should be taken as literal depictions of societal norms that the entire aristocracy followed, but rather as idealized, or even satirical, representations of fashionable, elite society. On the other hand, in many instances, these paintings depict readily identifiable household wares such as clocks and porcelain objects which are sometimes depicted with such verisimilitude as to be able to be matched with a ceramic pattern of a specific producer. Scholars have identified the tablewares depicted in Le dejeuner de jambon as that of Saint Cloud manufacture. Both the plates and the bottle chillers have been identified as conforming to a particular design. ${ }^{207}$ While this may not always be the case, the artists paid just as much attention to the objects they depicted as they did the sumptuous costumes of their characters, and the motifs or designs depicted on these objects often seem evocative of actual patterns. As depictions of fashion, these paintings and the objects depicted in them were both displays of and objects for conspicuous consumption. The decorative items and the objects that are depicted in the paintings

\footnotetext{
${ }^{205}$ Melissa Hyde, Making up the rococo: François Boucher and his critics (Los Angeles, CA: Getty Research Institute, 2006), 107-144.

${ }^{206}$ Denise Amy Baxter, "Fashions of sociability in Jean-François de Troy's tableaux de mode, 1725-1738" (Ann Arbor, Mich.: UMI Dissertation Services, 2004), 2.

${ }^{207}$ Holmes, Nicolas Lancret: Dance before a Fountain, 26 and Clare Le Corbeiller and Linda H. Roth, French Eighteenth-Century Procelain at the Wadsworth Atheneum (Hartford, CT, 2000), 23.
} 
fulfilled this role, just as the paintings performed a similar role as an item to be bought, or consumed, by the person who commissioned or purchased them.

One of the common themes taken up by artists of the period was that of beverage consumption. The theme served the function of displaying the wealth of the sitter, when applied to portraiture, and the luxury of leisure, both the act itself and the trappings that come along with such performances in genre paintings. The "work of leisure," as Mimi Hellman calls it, was a carefully construed notion that the act of leisure was not easy and must be learned and perfected, as such it was an aspect of honnêteté. ${ }^{208}$ This process was enhanced by the very same fashionable objects that the tableaux de mode depict. These objects help to assist in these acts through their usage. Furthermore, Hellman has noted that "decorative objects were social actors that both facilitated and, in a sense, monitored the leisure acts of privileged society." ${ }^{209}$ With this in mind, the different pieces of a tea, coffee or chocolate set can function, in these paintings as well as contemporaneous life, as signs of seemingly lighthearted pastimes which were actually carefully composed and constructed.

While chocolate, coffee, and tea were introduced into French culture in the midto second-half of the seventeenth century and appear in fashion prints of the time, it was not until the eighteenth century and the obsession with these leisure-time activities that they came to be depicted in fashionable paintings. Historian Wolfgang Schivelbusch noted with respect to coffee that "it was not the drink itself that mattered to court society but how it could be consumed, the opportunities it afforded for display of elegance,

\footnotetext{
${ }^{208}$ Mimi Hellman, "Furniture, Sociablilty, and the Work of Leisure in Eighteenth-Century France." Eighteenth-Century Studies (Vol. 32, No. 4, Summer 1999), 416.

${ }^{209}$ Hellman, "Furniture, Sociablilty, and the Work of Leisure in Eighteenth-Century France," 416.
} 
grace, and high refinement." ${ }^{210}$ In other words, the act and ideal of leisure that the drinking of the beverage implied was more important than the actual beverage. While the performative aspects of consumption are important, I argue that the ability to identify a particular hot beverage depicted by Lancret can help to give the painting more meaning than just its social connotations. Since all three beverages were the purview of the aristocracy or wealthy financiers during the eighteenth century, they all carried social connotations of the elite class. However, the connotations of the drinks varied greatly. Coffee was meant to stimulate the mind, chocolate was seen as an aphrodisiac, and tea was the drink of polite society. Given these specific connotations, the identification of the beverages depicted in Lancret's paintings could influence the viewer's interpretation of the work.

\section{A concise history of hot beverages in France}

Cacao was introduced to Europe through the Spanish and their exploration of the New World. ${ }^{211}$ There are conflicting stories as to how and when chocolate, the product of cacao, was introduced into France; however, there is evidence to suggest that the drink form of chocolate was introduced as early as 1615 or as late as $1642 .{ }^{212}$ One theory on the introduction of chocolate to France notes that in 1615, Louis XIII (1601-1643) married Anne of Austria (1601-1666), who was actually raised in Madrid, and it was with Anne that chocolate came to the royal court. ${ }^{213}$ Another theory suggests that Spanish monks

\footnotetext{
${ }^{210}$ Wolfgang Schivelbusch, Tastes of Paradise: A Social History of Spices, Stimulants, and Intoxicants, trans. David Jacobson (New York: Pantheon Books, 1992), 19.

${ }^{211}$ Sophie D. Coe and Michael D. Coe. The True History of Chocolate (New York: Thames and Hudson, Inc., 1996), 125.

${ }^{212}$ Coe, The True History of Chocolate, 155-156.

${ }^{213}$ Schivelbusch, Tastes of Paradise, 91.
} 
sent gifts to their French counterparts which included cacao, but as with the story of Anne of Austria, there is no concrete evidence to suggest that this was chocolate's primary means of introduction into French society. ${ }^{214}$ The final theory, and the only one with evidence to suggest its truth, is that chocolate was introduced to France by the older brother of Armand Jean du Plessis (1585-1642) the Cardinal de Richelieu who took the concoction for medicinal purposes. ${ }^{215}$

Regardless of its actual introduction, initially the taking of chocolate was thought to be a bad habit done by the Spanish alone; in fact, when Louis XIV, the son of Louis XIII and Anne of Austria, married María Teresa (1638-1683), a member of the Spanish branch of the Habsburg House, the Spanish Infanta was forced to drink her chocolate in secret because the young king did not approve of the custom. ${ }^{216}$ Chocolate was also believed to be a potentially dangerous drug. ${ }^{217}$ However, only a short number of years later, chocolate was widely accepted and the popular drink at court. ${ }^{218}$ It was served at the king's levées as well as most public functions at the court of Versailles. After the death of María Teresa in 1682, Louis XIV married the religiously pious Françoise d'Aubigné (16352-1719), Madame de Maintenon, under whose influence the court was stripped of some of its more ostentatious rituals, presumably including chocolate. ${ }^{219}$

\footnotetext{
${ }^{214}$ Coe, The True History of Chocolate, 155.

215 Barbara Ketcham Wheaton, Savoring the Past, The French Kitchen and Table from 1300 to 1789 (New York: Touchstone, 1983), 87.

${ }^{216}$ Coe, The True History of Chocolate, 158.

${ }^{217}$ Chevallier, “The Queen's Coffee and Casanova's Chocolate,” 197-198.

${ }^{218}$ Coe, The True History of Chocolate, 158.

${ }^{219}$ Alfred Franklin, La Vie Privee d'Autrefois: Le café, le thé \& le chocolat (Paris: E. Plon, Nourrit et Cie, Imprimeurs-Editeurs, 1893), 171.
} 
Tea became popular during the middle of the seventeenth century; it was most likely introduced by the Dutch due to their extensive trading networks in the East. ${ }^{220}$ Throughout the seventeenth century, tea remained an aristocratic drink due to the high prices of importation. ${ }^{221}$ However, tea was only popular in France for a short period, as coffee was the preferred beverage. ${ }^{222}$ This was most likely due to the high price of the dried leaves which cost 100 francs a pound, an exorbitant amount when compared to the 6 francs a pound for chocolate and 4 francs for coffee at its peak. ${ }^{223}$ Louis XIV often took tea for its assumed restorative properties but preferred coffee. ${ }^{224}$

Coffee is said to have been introduced to French culture a mere ten years after the introduction of tea in $1650 .^{225}$ By 1679 coffee was popular at court, with the Turkish Ambassador throwing lavish coffee-drinking parties. ${ }^{226}$ However, by the early $1690 \mathrm{~s}$ coffee had become a regulated import, only sold by a single fermier general, and the price jumped from 27 sous, slightly more than 1 franc a pound, to 4 francs - a price increase of $300 \% .^{227}$ The outcry against the price was so great that only a year later this sole purveyorship privilege was revoked, and coffee was once again the beverage of choice for the majority of Parisians, though it had fallen from favor with the royal court

\footnotetext{
${ }^{220}$ Roy Moxham, Tea: Addiction, Exploration and Empire (New York: Carroll \& Graf Publishers, 2003$), 18$.

${ }^{221}$ Moxham, Tea, 17.

${ }^{222}$ David Schapira, Joel Schapira, and Karl Schapira, The Book of Coffee and Tea (New York: St. Martin's Press, 1982), 164.

223 Maguelonne Toussaint-Samat, A History of Food, trans. Anthea Bell (Cambridge, MA: Blackwell Publishers, 1992), 578.

224 Toussaint-Samat, A History of Food, 599-600; Ann Eatwell, "Tea à la Mode: The Fashion for Tea and Tea Equipage in London and Paris" in Boucher and Chardin: Masters of Modern Manners (London: Paul Holberton publishing, 2008), 69.

${ }^{225}$ Schapira, The Book of Coffee and Tea, 10.

${ }^{226}$ Schapira, The Book of Coffee and Tea, 10.

227 Toussaint-Samat, A History of Food, 578; Coffee was still not as expensive as chocolate, coffee cost 4 francs a pound compared to six francs a pound for chocolate.
} 
who preferred chocolate. ${ }^{228}$ By 1721, Paris boasted over three hundred cafés, which served tea and chocolate in addition to coffee. ${ }^{229}$ Louis XV was said to have "a veritable passion" for coffee and was known to roast beans and prepare coffee himself. ${ }^{230} \mathrm{He}$ also grew 'coffee cherries' in his greenhouses at Versailles. ${ }^{231}$

Initially popular with the nobles due to the Turkish Ambassador's parties, as coffee became available to the bourgeois, it fell from favor with aristocracy, the very people who had help popularized the drink. ${ }^{232}$ Chocolate remained an aristocratic drink in France until after the Revolution, when it was made available to people of all classes. ${ }^{233}$ Tea was seemingly also an aristocratic drink until just before the French Revolution, after which it appears that French consumption of tea became increasingly widespread. ${ }^{234}$

These beverages, when first introduced, were used primarily for medicinal purposes. Medicinal philosophies about the drinks tended to revolve around Hippocrates's mid-fifth to mid-fourth century BCE theories of the four humors: blood, phlegm, and yellow and black bile. The theory was later picked up by the Galen in the second century CE and expanded to include the categorizations of 'hot', 'cold', 'dry', and 'wet' in relation to the humors, maladies, and cures. According to Hippocrates, diseases were caused by the imbalance of the humors, using Galen's embellishments to the theory:

\footnotetext{
${ }^{228}$ Schapira, The Book of Coffee and Tea, 92-93.

229 Toussaint-Samat, A History of Food, 587.

${ }^{230}$ Franklin, La Vie Privee d'Autrefois: Le café, le thé \& le chocolat, 234.

231 Toussaint-Samat, A History of Food, 585.

${ }^{232}$ Robert Forster and Orest Ranum, eds. Food and Drink in History, trans. Elborg Forster and Patricia M. Ranum (Baltimore: The Johns Hopkins University Press, 1979), 92.

${ }^{233}$ Coe, The True History of Chocolate, 235.

${ }^{234}$ Jean Maurice Biziere, "Hot Beverages and the Enterprising Spirit in Eighteenth-Century Europe." The

Journal of Psychohistory (Vol. 7, No. 2, Fall 1979), 136.
} 
a 'cold' illness called for a 'hot' cure, just as a 'dry' complaint called for a 'wet' treatment to realign the humors. ${ }^{235}$

In regard to Galen's theory on the humors, coffee was said to be 'hot' and 'dry. ${ }^{, 236}$ Even in the seventeenth century, coffee was theorized as a sobering drink, a connotation it still holds. ${ }^{237}$ At its first introduction coffee was said to help with ailments varying from colic to dropsy, alleviate stomach problems and stimulate hunger or suppress it. Conversely, it was said to keep a person awake but also put them to sleep. ${ }^{238}$ Tea was viewed much the same as coffee, and both drinks were thought of as a pair. ${ }^{239}$ Tea was similarly noted as 'hot' and 'dry' and was a remedy for a number of various ailments, as well as a sobering beverage similar to coffee. ${ }^{240}$ Chocolate was noted for its nutritional value by most early doctors. ${ }^{241}$ Many different recipes for chocolate existed at the time; the possible additions to the chocolate drink coincided with Galen's theories of the humors. Vanilla was said to be 'hot' while mecaxochitl, a relative of black pepper, was 'hot' and 'dry.' How the chocolate was mixed and what ingredients were added to it depended on the state of the drinker's humors. ${ }^{242}$ Though cacao, the seed from which chocolate is made, was thought to be 'cold' and between 'wet' and 'dry' at 'humid. ${ }^{243}$

Sugar was added to coffee, tea, and chocolate to make them palatable and many early manuals on the drinks included sugar to make the drinks adhere to the taste of

\footnotetext{
${ }^{235}$ Coe, The True History of Chocolate, 121.

${ }^{236}$ Coe, The True History of Chocolate, 168.

${ }^{237}$ Schivelbusch, Tastes of Paradise, 35.

${ }^{238}$ Schivelbusch, Tastes of Paradise, 19.

${ }^{239}$ Schivelbusch, Tastes of Paradise, 84.

${ }^{240}$ Coe, The True History of Chocolate, 169.

${ }^{241}$ Schivelbusch, Tastes of Paradise, 87.

${ }^{242}$ Coe, The True History of Chocolate, 128.

${ }^{243}$ Coe, The True History of Chocolate, 123.
} 
Europeans. Sugar had been introduced to Europe centuries before; however, it was primarily used as a spice, preservative, or mixed with gum-paste to make table sculptures. Another ubiquitous use for sugar was Sweetmeats, which had been eaten since the Middle Ages; preserves and candied fruits and nuts were often served as a course during aristocratic banquets. ${ }^{244}$ The French West Indies had been growing sugar cane and shipping it back to the mainland since the $1640 \mathrm{~s} .{ }^{245}$ The importation of sugar was a major industry for the French during the seventeenth and into the eighteenth century. One-fifth of all refined sugar was supplied by French factories, and investment in the companies was a matter of pride for the aristocracy and wealthy financiers. Sugar was not only an economic force, it was the major impetus behind colonization and slave labor. ${ }^{246}$ It did not attain its widespread status as a beverage sweetener, however, until the mideighteenth century. ${ }^{247}$

All four substances, chocolate, tea, coffee, and sugar, were products of colonialism or the increased globalism of the eighteenth century. These "exotic commodities were Europeanized, their foreignness domesticated, their vigor tamed, and their poison neutralized" over a process of many years. ${ }^{248}$ The frontispiece to Philippe Sylvestre Dufour's 1685 Traitez Nouveaux et Curieux du café, du thé, du chocolat (figure 83) curiously depicts three figures who can easily be identified by the three beverages they hold and is evidence of this global economy. The men are shown in a shallow space

\footnotetext{
244 Toussaint-Samat, A History of Food, 565-566.

245 Toussaint-Samat, A History of Food, 557.

246 Toussaint-Samat, A History of Food, 559-560.

247 Yao-Fen You, "From Novelty to Necessity: The Europeanization of Coffee, Tea, and Chocolate" in Coffee, Tea, and Chocolate: Consuming the World edited by Yao-Fen You (New Haven: Yale University Press, 2016), 61.

248 You, "From Novelty to Necessity," 50.
} 
punctuated by a hanging curtain, situated around a short, round table which sits atop a rug. The 'Chinaman' holds a shallow handless cup and is seated next to vessel of medium height, while the 'Turk' is seated in the center holding a cup almost identical to the Chinaman's with a short, squat vessel resting on the table just to his left. Standing at the right of the composition is an 'American Indian' who holds a double handed cup by its foot with a tall vessel and wooden rod at his feet. The Chinaman represents tea, the Turk, coffee, and the American Indian, chocolate. Three of the four continents are depicted in this image: the Americas in the west, Asia in the east, and Africa to the south. While Turkey was technically part of Asia, the close association of Turks, Africans, and Moors may have lead the eighteenth-century viewer to make the connection to Africa as opposed to Asia.

This image of a global economy is furthered through the European use of sugar to sweeten these beverages. While sugar is not represented in this frontispiece, its inclusion is implicit. Sugar was often viewed as a product of the New World since France's colonies had been growing it there for over a hundred and fifty years. In addition to sugar, Martinique and the Antilles islands were used to grow cacao. ${ }^{249}$ Martinique, San Domingo, and Guadeloupe islands were also used by the French to cultivate coffee. It is estimated that by 1789 the three islands produced eighty-seven million kilograms of coffee. ${ }^{250}$ All of these exotic foodstuffs were the product of increased globalization and colonization. As such, their exotic nature, as depicted in paintings, was seemingly transferred to the drinker. Christine Jones has observed that these beverages placed

\footnotetext{
${ }^{249}$ Coe, The True History of Chocolate, 218.

${ }^{250}$ Alfred Franklin, La vie privée d'autrefois : arts et métiers, modes, moeurs, usages des Parisiens, du XIIe au XVIIIe siècle. 13 (Paris: E. Plon, 1887-1902), 104-108.
} 
"consumption on a world stage and invite French drinkers to participate in intercontinental exploration - a kind of artisanal safari - right at their dining room table." ${ }^{251}$ The ability of the people in the paintings to afford these imported luxury goods is therefore a display of their social standing and a means for expressing their honnêteté in addition to their fashionabilty.

\section{The Material Culture of Hot Beverages}

As coffee, tea, and chocolate were introduced into the French culture, they developed different serving methods and associated service wares. While some of the vessels used for serving and drinking were based on the antecedent forms of the cultures from which they came, the French modified these objects for their own uses. A number of the objects became interchangeable, causing some uncertainty in forms.

Chocolate pots developed into a tall, slender form with a wide belly and a long, tapered neck; these serving vessels would often have a wooden-clad handle extending away from the pot. Since metal conducts heat, this enabled the pourers to hold the vessel without burning themselves (figure 84). Both of the silver and porcelain chocolate vessels had short pouring lips close to the neck of the pot and lids which were either hinged or a completely separate piece (figure 85). Silver chocolate pots often had a small finial at the top of the lid which would slide open to reveal a hole. The hole allowed for a wooden moulinet or moussoir to be inserted to froth the chocolate before pouring. The molinillo, the Spanish term of the French moulinet, was developed in the sixteenth century by the

\footnotetext{
${ }^{251}$ Christine A Jones, "Exotic Edibles: Coffee, Tea, Chocolate, and the Early Modern French How-to" in
} Journal of Medieval and Early Modern Studies, 43:3, Fall 2013, 635. 
Spanish colonials (figure 86). The form of the pot echoed the wooden and pottery vessels that Mesoamericans used to make chocolate. ${ }^{252}$

Tea pots are typically designed as egg or oval shaped, short, squat vessels with long pouring spouts, similar to their Asian predecessors. The handle on the vessel typically attaches to the body and the slightly tapered neck. Similar to the coffee and chocolate pots, tea pots had either hinged or fully detached lids; again, when made of silver, tea pots often had wooden handles (figure 87 and 88). Unlike coffee and chocolate pots, the wooden handle of the tea pots remained fully attached to the body of the vessel and did not extend out at a ninety-degree angle.

The coffee pot developed along the same lines as the chocolate pot, possibly due in part to the 1687 treatise by Nicolas de Blegny, Le Bon usage du thé, du caffé et du chocolat pour la preservation et pour la guérison des maladies. In this work, de Blegny advocates using a vessel very similar to the chocolate pot so as to not mix the coffee grounds in the bottom of the vessel when serving the liquid. ${ }^{253}$ This issue also affected the location of the spout which is typically placed higher on the vessel so as to not disturb the grounds when pouring. As with chocolate pots, the coffee pots would have a wooden handle when made of silver that extended away from the body of the vessel. In fact, the only way to tell the difference between a silver chocolate pot and a coffee pot is the presence or absence of the moulinet hole on the top of the vessel (figure 89). This assumes that the users were aware of the differences in forms and had the money to purchase a specific vessel for a specific beverage, though they were most likely used

\footnotetext{
${ }^{252}$ Coe, The True History of Chocolate, 160-161.

${ }^{253}$ Nicolas de Blégny, Le Bon Usage de thé, du caffé et du chocolat pour la préservation et pour la guérison des maladies (Lyon: Chez Thomas Amaulry, 1687), 152-154.
} 
interchangeably in real life. Similarly, in porcelain form, chocolate pots and coffee pots were indistinguishable and used for both liquids.

Just as interchangeable as the coffee and chocolate pots are the cups utilized with each beverage. The traditional Asian form of the shallow bowl-like cup was utilized with the introduction of tea into the French and English repertoire. While the Chinese typically drank green tea, the English developed a taste for black tea, which is steeped at a higher temperature than its green counterpart. As a result, the English developed a need for a handled tea cup to serve the function of holding the cup without having to touch the warm porcelain. ${ }^{254}$ The French, it seems, used both forms of the cup, the handle-less and the handled (figure 90 and 91). These cups served to function as both tea and coffee cups. Chocolate cups were also initially made with no handle, as seen in a seventeenth-century Nicolas Bonnart (1637-1718) print (figure 92). They developed as a taller, more slender form than their tea and coffee cousins; some chocolate cups were based on the early Mesoamerican form of the mancerina and jicara, a saucer and cup with double handles (figure 93). This form was transferred to France and called a trembleuse. ${ }^{255}$ Often, this vessel was a combination of the two forms, more tall and slender than a coffee or tea cup but with only one handle.

The variance in form of the cup also depended on the status of the purchaser: wealthier consumers would presumably have different cups for different beverages as seen in an eighteenth-century Meissen set (figure 94). The set includes tea or coffee cups, which are used interchangeably, located on the left with two on either side of the front of

\footnotetext{
${ }^{254}$ Beatrice Hohenegger, "The Tea Craze in the West" in Steeped in History: The Art of Tea, ed. Beatrice Hohenegger (Los Angeles: The Fowler Museum at UCLA, 2009), 131.

${ }^{255}$ Coe, The True History of Chocolate, 160-161.
} 
the case surrounding two one-handled chocolate cups, the rest of which are on the right of the box, totaling six cups per distinct form. This set, like many other sets, includes only one vessel for serving coffee and chocolate, as the smaller, similar form is a milk pitcher, and the teapot is located in the center. The similarity of forms as seen in the coffee and chocolate pots and the tea and coffee cups is further conveyed in the eighteenth-century depictions of beverages services. While the true identity of the forms or beverages depicted may not be discernable or have been lost to time, the acts of leisure and affluence are still recognizable.

\section{Hot Beverages and Sexual Encounters}

Nicolas Lancret's first depiction of a leisure activity including a fashionable beverage appears in the painting Le Matin (figure 95) from 1739. This painting belongs to a series of the hours of the day, Les Heures du Jour, which also includes paintings depicting midday, Le Midi (figure 96); afternoon, L'après-diner (figure 97); and evening, La Soirée (figure 98). The series depicts pastimes of the aristocracy which were common subjects of eighteenth-century paintings. Le Midi depicts a party picking flowers, L'après-diner a game of backgammon, and La Soirée a bathing scene. Whether these paintings were a commission or an independent project by the artist remains unknown.

Les Heures du Jour: Le Matin (figure 95) depicts an interior where a lady and a visitor sit partaking in a hot beverage; as indicated by its title, this painting is the morning scene, and according to the conventions of this type of series, the morning scenes normally depicted the woman's daily toilette ceremonies where she would often receive 
visitors. ${ }^{256}$ The ritual of the toilette was inarguably the most elaborate depiction of feminine leisure time and conspicuous consumption in the eighteenth century. Lancret depicts the indispensable items of the lady's toilette table on the left, with the smaller round table holding the beverage service on the right. Obviously, the visitor has interrupted her morning ritual; her lower body remains directed towards her toilette table and she twists to her left to pour her admirer a cup of hot liquid. The room is lavish with numerous paintings hanging on the white wall panels: a gilt clock; a green sofa; and sumptuous linens framing the glass-paneled door and draping over the toilette table, mirror, and sofa. The woman is dressed in a salmon-colored skirt decorated with a fine white floral print. Her maid stands behind her wearing a slightly darker reddish-pink dress and holds her mistress's hairpiece, which consists of the main cap decorated with flowers and two wings of lace, or lappets, on either side. ${ }^{257}$ The male visitor is dressed in black with only small touches of his white undershirt peeking out. The white ruffle of his collar identifies him as an Abbé, since it is a clerical cravat.

Le Matin was included in the 1739 Salon and described as "Autre [tableau] plus pétit "une Dame à sa Toilette, prenant du Caffé." ${ }^{258}$ The description of the painting by the Chevalier de Neufville de Brunabois Montador, Jean-Joseph-Florent (1707 - 1770), is more telling. The author describes the painting as

One other little one [painting] by him [Lancret] which again is very infatuating..., it is a fashionable Abbé at the toilette of a gallant woman. This young woman (with her shirt nonchalantly open and dressing gown thrown open without great care, allowing a glimpse of the objects which inspire guilty thoughts, for me a bit like a Tartuffe) pours the tea in to a cup for M. l'Abbé who holds it out with a distracted air; because he is attentive only to the disorder of this beauty's disarray. A maid who sees all of this, grins slyly. The

\footnotetext{
${ }^{256}$ Holmes, Nicolas Lancret 1690-1743, 90.

${ }^{257}$ Aileen Ribeiro, Dress in eighteenth-century Europe: 1715-1789 (New York: Holmes \& Meier Publishers, Inc., 1984), 111.

${ }^{258}$ L'Academie Royale, Explication des Peintres, Scultpures, et Autres Ouvrages de Messieurs de L'Academy Royale, 1739, 19.
} 
[salon] crowd, who is never easy to please, their praise is little suspect on seeing these small gallant subjects. ${ }^{259}$

The inclusion of the Abbé in the painting is not completely irrelevant as the toilette was a place where women not only enjoyed the company of friends but also conducted business. ${ }^{260}$ Scholars have described this painting as "a light psychological study of what transpires when a pretty young woman en déshabillé shares a cup of tea with a French abbe. ${ }^{261}$ However, I argue that this painting is purposefully sexual in nature and the Abbé not as innocent as he may appear. Scholar Aileen Ribeiro has noted that Abbés were often present at a woman's morning toilette, as they may have served as a cicisbeo or chevalier servant. ${ }^{262}$ Men in these positions were unmarried noblemen usually younger than the woman's husband, who were official escorts or openly-acknowledged lovers who would accompany a married woman to public events and even church services. ${ }^{263}$ The common French title of petit-maittre would also be applicable in this situation as these religious figures often provided gossip and news as well as possibly being paramours. In these instances, the title of Abbé was more honorable than an actual indication of religious affiliations or occupation. The Abbé appears to be captivated by the woman as the Chevalier de Neufville noted. It may be that this is their first sexual

\footnotetext{
${ }^{259}$ Jean-Florent-Joseph de Neufville de Brunabois Montador, Description raisonnée des tableaux exposés au Salon du Louvre, 1739, Lettre à Madame la marquise de S.P.R., (Paris : De l'Imprimerie de ClaudeFrançois Simon, fils, 1739), 9-10 ; «Une autre morceau de lui qui est encore bien touché, est un Abbé de mode à la toilette d'une femme galante. Cette jeune personne (dont la chemise négligemment ouverte, \& le peignoir détourné sans grande inquiétude, laisse voir des objets dont les âmes blessées sont naitre dans le cœur de coupables pensées, pour n'exprimer à peu près comme Tartuffe) verse de Thé dans une tasse que M. l'Abbé lui présente d'un air distrait ; parce qu'il n'est attentif qu'au désordre de cette beauté. Une Soubrette qui examine tout cela, en sourit finement. La foule qui est toujours à la croisée où voit ces petits sujets galants leur sont des éloges peu suspects. »

${ }^{260}$ Ribeiro, Dress in eighteenth-century Europe: 1715-1789, 123.

${ }^{261}$ Anne Dulau, ed. Boucher and Chardin: Masters of Modern Manners (Glasgow: University of Glasgow and Paul Holberton Publishing, 2008), Catalogue entry 6: 92-9.

${ }^{262}$ Ribeiro, Dress in eighteenth-century Europe: 1715-1789, 123.

${ }^{263}$ Silvana Patriarca, Italian Vices: National Character from the Risorgimento to the Republic (Cambridge: Cambridge University Press, 2010), 40.
} 
encounter, given his enthrallment and her attempt at seduction through the nonchalant exposure of her breast.

Furthermore, the hot liquid pouring from the phallic spout of the vessel into an empty cup can plainly be seen as a sexual metaphor and is perhaps an indicator for a future erotic encounter. Therefore, the woman and the vessel she pours from are complicit in a series of manipulations that require a joint performance by them both. ${ }^{264}$ The maid only further adds to the sexual nature of the painting, as she smiles coyly at the seductive actions of her mistress. This coy smile by the maid begs the question of the woman's intentions. The maid's smile is indicative of her prior knowledge of her mistress's seductive ventures. Furthermore, the headdress of her mistress indicates that she was married, as married women were required to cover their hair. ${ }^{265}$ This then places the actions of the woman within a well-defined social role of playing the part of a naïve or unassuming seductress - the Tartuffe, or pious pretender mentioned by the Chevalier de Neufville. As a Tartuffe, the woman is not innocent, she knows full-well the significance of her actions and is most likely prepared a few other snares in case her first attempts do not succeed.

Despite not being readily identifiable, the beverage consumed in the painting also helps to further the erotic undertones of the painting. The 1739 Salon mention of Le Matin identifies the beverage as coffee while the Chevalier states that the beverage is tea. The identification of the hot liquid is wholly due to the service items depicted by the artist, which is not one cohesive set but a conglomeration of various pieces. The short

\footnotetext{
${ }^{264}$ Hellman, "Furniture, Sociablilty, and the Work of Leisure in Eighteenth-Century France," 424.

265 Anne Dulau, "In Focus: Lady taking Tea and Woman on a Daybed" in Boucher and Chardin: Masters of Modern Manners (London: Paul Holberton publishing, 2008), 16.
} 
serving pot indicates coffee or tea and is made of silver while the sugar bowl is porcelain and the set of cups are glazed earthen ware. Hellman has noted that "the deliberate mismatched ensemble...has become a sign of creativity and sophistication."266 The presence of these sophisticatedly mismatched pieces suggests the fashionability of the woman depicted. Still, this service set does little to clear up the question of the beverage being portrayed here.

While the silver serving pot reiterates the form of Asian teapots, it also resembles the early coffeepot as seen in the depiction of a Turkish man, a Chinese man, and an American Indian with their respective drinks in Dufour's frontispiece (figure 83). ${ }^{267}$ In this instance, the forms of the spouts do not match. Furthering the hypothesis that the serving vessel is a coffeepot as opposed to a teapot is an illustration from Alfred Franklin's La vie privée d'autrefois: Le Café, Le Thé et le Chocolat. This image depicts a street vendor using the same type of serving vessel with the notation "Vendeur de Caffé par les rues" (figure 99). ${ }^{268}$ The spouts of both pots appear to be only slightly higher than those of a traditional teapot. The cups depicted by Lancret were wide, shallow, and without handles, reiterating the indigenous forms of their Asian predecessors; the type of cup depicted was used for both tea and coffee. Though the identification of the liquid is unclear, as previously stated, coffee and tea were often seen as a pair - both being 'hot,' 'dry,' and sobering. Regardless of the identification of the beverage, what mattered

\footnotetext{
${ }^{266}$ Mimi Hellman, "The Joy of Sets: The Uses of Seriality in the French Interior" in Furnishing the Eighteenth Century: What Furniture Can Tell Us About the European and American Past, ed. Dena Goodman and Kathryn Norberg (New York and London: Routledge, 2006), 131.

${ }^{267}$ Philippe Sylvestre Dufour, Traitez Nouveaux \& Curieux du Café, du Thé et du Chocolate (La Haye: Chez Adrian Moetjens, 1685), 5.

${ }^{268}$ Franklin, La Vie Privee d'Autrefois: Le café, le thé \& le chocolat, fig. 1.
} 
simply was that it was hot, and it allowed for many different interpretations of the image. $^{269}$

While the serving vessel may not clarify the beverage included in the painting, other factors might. A recent exhibition catalogue that included this painting, Boucher and Chardin: Masters of Modern Manners, continues the discussion of tea versus coffee but simply notes the salon mention of coffee as incorrect. The catalogue instead describes the beverage as tea, citing the fact that tea was commonly associated with the morning toilette. ${ }^{270}$ This identification also may be based on the service set, since a number of tea sets were sold without the serving vessel but only included two cups and saucers, similar to the mismatched nature of the set depicted by Lancret. Ann Eatwell suggests that these small sets indicate that tea was an intimate act or taken with a friend or lover. ${ }^{271}$ Another less recent publication, Schivelbusch's Tastes of Paradise, contends that the beverage displayed may have actually been chocolate due to the erotic associations of the beverage; chocolate was considered an aphrodisiac. ${ }^{272}$ The humoral properties of chocolate confirm this association of the beverage as an aphrodisiac since it was thought to create excessive heat, yet it was also thought to fight against venereal disease. ${ }^{273}$ Ironically, and in contradiction, chocolate can be seen as a cause of the contraction of the very disease it purportedly cured. Though the identification of chocolate in this instance is aptly appropriate, it does not appear to be accurate. However, what mattered was the

\footnotetext{
${ }^{269}$ Eatwell, "Tea à la Mode," 53.

${ }^{270}$ Dulau, Boucher and Chardin, 92-93, Catalogue entry 6 ; 22.

271 Eatwell, "Tea à la Mode," 69.

${ }^{272}$ Schivelbusch, Tastes of Paradise, 92.

${ }^{273}$ Musée Cognacq-Jay, Thé, Café ou Chocolat ? Les Boissons Exotiques à Paris au XVIIIe Siècle (Paris :

Paris Musées, 2015), 12.
} 
viewer's own interpretation of the image as opposed to an exact identification of the fashionable hot beverage.

Despite Schivelbusch's discussion of chocolate's erotic associations and assertion of chocolate as the beverage of choice for aristocratic women at their morning toilette, the serving vessel depicted by Lancret certainly does not fit the prescribed form of a chocolate pot but that of tea or coffee. While the serving vessel may match the form of a coffeepot, the associations of coffee disallow its identification here. Coffee was thought to be antithetical to chocolate, and in this way, it was antierotic, "what coffee gave to the mind it took from the body." 274 The social associations of tea were, and still are, that of polite society. Tea is an accompaniment of polite social activities yet another chance for a woman to exhibit her knowledge of social performance during the eighteenth century. Popularly, tea was believed to be the beverage of choice for ladies and was commonly consumed at the toilette, as previously mentioned. ${ }^{275}$ In Le Midi, Lancret uses the tea as a ruse for the meeting, a social convention meant to lure the Abbé under the pretenses of a polite society meeting, further evidenced by the inclusion of four cups as opposed to two on the table. The beverage is therefore an excuse for erotic engagement.

Scholars commonly compare Lancret's Le Midi to Boucher's (1703-1770) La Toilette (figure 100). Only three years after did Lancret, Boucher similarly depicted a fashionable interior with a woman and her maid. Boucher's painting is rife with thinly veiled eroticism of a different type: the woman is in the process of fastening her garter, her legs splayed with a cat lying at her feet. The fireplace bellows are also pointed in the

${ }^{274}$ Schivelbusch, Tastes of Paradise, 92.

275 Toussaint-Samat, A History of Food, 598. 
direction of the woman's skirt, a presumed love letter lies on the mantle, a black syphilitic beauty mark appears on the woman's face, and a small table is set with tea for two. While Lancret's woman may be playing coy, Boucher's does not appear to hide her indiscretions and wears them quite literally on her face.

However, Les Heures du Jour: Le Matin might more easily be compared to a slightly later painting by Jean-Baptiste Le Prince (1734-1781), Fear (figure 101), at least with regard to the erotic potential of the scene and the aphroditic associations of hot beverages. In Le Prince's painting a woman is seen in her boudoir, one breast exposed, with an overturned chair on the floor. The matching chair is shown behind a small table on which a chocolate pot and a pair of cups are set. A small dog chases after an unseen figure outside of the picture to the left. The vessel on the table is readily identifiable as a chocolate pot, since the wooden moulinet is depicted sticking out of its top and tall, slender, single-handled cups accompany it. The ability of chocolate to fuel amorous intrigues is evident in this painting.

The other paintings in Lancret's Times of Day series also include subtle hints of a sexual nature: Le Midi depicts flower-picking, L'après-diner shows a game of backgammon, and La Soirée is a scene of women bathing, their breasts exposed in a manner similar to that of the woman in Le Matin. Flower-picking is a fairly common subject for Rococo paintings and is often seen as a way to reference the lost innocence or virginity of the scenes' female participants. The woman has been de-flowered, as has the flowering plant. Gambling and games were both social pastimes that carried amorous 
connotations of caution and pursuit. ${ }^{276}$ Women bathing, which seems to have developed from mythological origins as will be discussed in Chapter Four, is another common subject matter for painting during the Rococo period. Furthermore, paintings of this subject matter are often meant for voyeuristic male consumption and as such carry sexual connotations. The small size of the images indicates they were probably meant for personal viewing, possibly as cabinet paintings. Cabinet paintings are typically smaller, intimate paintings that were displayed in a cabinet, or a small, private room in a French house, into which only the closest friends of the owner would be allowed. Furthermore, scholar Angus Trumble has noted in his essay, "Tea and the Conversation Piece," with respect to French genre paintings which depict people consuming hot beverages, that the tea, coffee, and chocolate depicted are "not merely conspicuous but to some degree explain or contextualize those social games that might safely be played in the boudoir and the closet." 277 In this instance, the closet is associated with the cabinet, and therefore furthers the association of this series of paintings as cabinet paintings originally on display in the small room of the same name.

Lancret's Times of Day series was engraved by Nicolas de Larmessin (16321694) shortly after the completion of the series and included passages by the poet PierreCharles Roy (1683-1764) with the engraved images. ${ }^{278}$ Le Matin is accompanied by a verse stating, "Leaving the taste of the sweetness of Twilight sleep, the care of the adornment will soon have its turn this light pastime for her opens the day and the art of

\footnotetext{
276 Nina L. Dubin, "Man of Numbers" in Casanova: The Seduction of Europe ed. Frederick Ilchman et al. (Boston: MFA Publications, 2017), 249-253.

${ }^{277}$ Angus Trumble, "Tea and the Conversation Piece" in Steeped in History: The Art of Tea, ed. Beatrice Hohenegger (Los Angeles: The Fowler Museum at UCLA, 2009), 154.

${ }^{278}$ Paul Ackroyd, Ashok Roy and Humphrey Wine, "Nicolas Lancret's "The Four Times of Day"” National Gallery Technical Bulletin Vol 25 (2004), 48-61, Note and References 13.
} 
the beauty makes a trophy." 279 The inclusion of this poem not only speaks to the art of the toilette as a leisurely activity but reiterates the allure of the young woman. The rest of the printed series also contains verses speaking about beauty and love that reinforce the subject matter of each painting. For instance, similar to the verses included with La matin and the awakening of beauty at the toilette are the verses with L'après-diner which speak of love as dependent on chance much like the game the seated couple is playing.

\section{Beverages and The Progress of Love}

The use of beverages in images of sexual encounters is also found in the series of overdoors currently in the collection of the Fine Arts Museums of San Francisco. This series (figure 102-105) includes a set of images that do not necessarily explicitly exhibit sexual encounters, but their subject matter can still be interpreted as having amorous connotations. Despite the works not containing a clear narrative or progression, the amorous nature of the images is played out over the four panels.

Lacking a clear narrative, the subject of two of the four paintings, La petit déjeuner avant la chasse and Le Fin de la Chasse, are clearly related to the aristocratic pastime of the hunt. A third work, Baigneuses, also has lingering connections to the hunt that will be further discussed in the following chapter. In La petit déjeuner avant la chasse Lancret has depicted a hot beverage, reinforcing the importance of the consumption of beverages during a pre-hunt ritual of the rendez-vous.

\footnotetext{
${ }^{279}$ Nicolas de Larmessin IV, Print of Le Matin after Nicolas Lancret. Google Arts \& Culture, Collection of the National Gallery of Art, Washington D.C, 1741, Print. https://artsandculture.google.com/asset/lematin/LQGR_YxDM1PsWw; «En Sortant de gouter les douceur de Morfée, Les Soins de la Parure auront bientôt leur tour Ce léger passetemps pour elle ouvre le jour Et l'Art a la Beauté va dresser un Trophée. »
} 
This series of paintings is traditionally thought to be overdoors commissioned for the château Marly-le-Roi around 1740. The château at Marly was sold after the French Revolution and eventually destroyed in the early years of the nineteenth century. Much documentation of the château remains, though the latest surviving inventory of Marly dates to 1733 , presumably seven years before the completion of the paintings. Moreover, the paintings are not included in Fernand Engerand's 1899-1900 comprehensive inventory of royal commissions. They do not appear to have any known provenance before $1851 .^{280}$ Furthermore, not much research has focused on these paintings and their probable placement within the château, if it was in fact their originally intended location; therefore, their order or the sequence in which they were meant to be viewed is unknown. It appears La petit déjeuner avant la chasse (figure 102) may be the first painting in the series given its title, and the implications of it as taking place in the mid-morning or early afternoon. La petit déjeuner avant la chasse is followed by Concert Champêtre (figure 103), then Le Fin de la Chasse (figure 104), and finally, Baigneuses (figure 105). ${ }^{281}$ This presumed temporal sequence is enhanced by the previously discussed series by the artist in which the bathing scene was the final scene in the series. Similarly, the series for Marly-le-Roi can be read as a thinly-veiled sexual pursuit through the use of references to the hunt.

\footnotetext{
${ }^{280}$ Whether or not Marly-le-Roi was the original intended location of these paintings is a matter of debate. While this is traditionally believed to be their original location there appear to be no documents that corroborate these paintings as a royal commission. See Pierre Rosenberg, French Paintings 1500-1825, The Fine Arts Museums of San Francisco (San Francisco: The Fine Arts Museums of San Francisco, 1987) for further discussion of the provenance of these paintings.

${ }^{281}$ Wildenstein, Lancret, 120, no 746, fig. 180; Wildenstein notes the name of Le Fin de la Chasse as Hallali. Hallali is a reference to the cry of the hunting party, des hallalis, to indicate that the prey has been brought to bay.
} 
The first image, La petit déjeuner avant la chasse, is similar to Le Matin in numerous ways; although, in this painting, the man appears to be the one attempting to seduce the woman. Le petit déjeuner avant la chasse depicts a man in hunting costume sitting at a table in a landscape. His rifle is awkwardly positioned behind his left leg and the crook of his right arm. He leans on the table with his left arm and holds a cup and saucer in his left hand. On the table sits a small beverage service, and across from the man sits a woman in a stylish blue-green robe volante. To the right of the woman another hunter stands holding his gun with the stock on the ground and barrel in his hand. $\mathrm{He}$ appears to be gesturing towards the gun while looking at a dog who stands in front of him. The right third of the canvas depicts a lush green landscape, presumably the hunting grounds into which the men will disappear after this petit déjeuner has concluded.

The beverage service in this instance consists of two white porcelain cups and silver spoons held by the seated man and woman, the serving vessel on the center of the table flanked by at least three other cups and saucers. One cup appears to have been used by the standing man, while others remain unused sitting upside down in their saucers. The beverage depicted appears to be tea or coffee based on the form of the vessel and the type of cups depicted. While tea may have been the beverage of choice for the morning toilette, coffee may be depicted here as it was thought to be energizing and intellectually stimulating - a good way to start a hunt. ${ }^{282}$

While this image does not appear to be as overtly sexual as Le Matin, there are references in the painting that give it a sense of carnality. First, the position of the gun

\footnotetext{
${ }^{282}$ Musée Cognacq-Jay, Thé, Café ou Chocolat ?, 12.
} 
between the legs of the seated man is rather phallic; its placement and metaphorical meaning is not subtle. Second, the theme of the hunt is one of pursuit; in this instance the pursuit of sex as the seated man stares rather brazenly at the young woman who shyly and demurely looks down at her porcelain cup. Here, again, may be an instance of polite society in which the woman does not want to openly indicate her complicity in her own seduction. Finally, when viewed within the context of the other paintings which include a serenade, Concert Champêtre (figure 103), and women spied on while bathing, Baigneuses (figure 105), the amorous intentions of the series become clear. Furthermore, the woman pointing to the stag in Le Fin de la Chasse (figure 104) indicates the end of the pursuit as she gestures toward the dead stag. However, whether the man is seducing the woman, or the woman is seducing the man is left up to the viewer.

A different interpretation of the series is that of the Progress of Love, another common theme among serial paintings of the eighteenth century. Read in this way, the series starts not with Le petit déjeuner avant la chasse but with Baigneuses in which the prey is initially spotted by the two male figures hidden in the bushes. Le petit déjeuner avant la chasse marks the beginning of the chase in which both parties are complicit, Concert Champêtre an intermediate image of courtship, and Le Fin de la Chasse the closing image of the series, depicting the now-old woman gesturing to the fallen prey. The woman gestures knowingly towards the dead stag as though to indicate she achieved her aims and that the chase is over. In other words, she was able to succeed in her cool seduction of her seated companion from Le petit déjeuner avant la chasse, indicating her initial shyness as mere social convention. Sheriff has discussed how series of this type are 
open to interpretation, allowing viewers to formulate their own personal narratives based on experience or imagination. ${ }^{283}$ The ability of the viewer to reorder these paintings

\begin{abstract}
...need[s] not necessarily encompass all four panels or be limited to them. The scenes do not so much challenge viewers to order them in the correct sequence (the sequence privileged by the artist) as invite them to participate in the creation of a narrative by using both the painted scenes and any other scenes imagined to complement them... [they] are not a single narrative but many potential narratives, any one of which can be activated by the viewer, who is free to choose from among the many suggestive comparisons and contrasts...284
\end{abstract}

This interpretation is, however, complicated by the unknown original installation of this overdoor series. The way in which these paintings were situated across from or diagonal to one another is undetermined. This obstacle does not actually detract from the modern viewer's assimilation of the images to create a narrative but enables it. The viewers are not hindered by "the sequence privileged by the artist," as Sheriff stated, but are allowed to order and reorder the images as they wish, perhaps more so than if the original sequence of the paintings was known.

In both interpretations, either the temporal reading or that of a Progress of Love, Le petit déjeuner avant la chasse plays a pivotal role in the series, either as the first image in the series or the beginning of the courtship. As will be discussed in the following chapter, it was not uncommon for the hunting party to stop during the day-long hunting excursion to eat. However, that is not what Lancret has depicted in this instance. The painting is titled breakfast before the hunt, indicating that the hunt has not yet started and that the man has taken the time to sit down with this young woman before the hunting

\footnotetext{
${ }^{283}$ Mary D. Sheriff, Fragonard: Art and Eroticism (Chicago: The University of Chicago Press, 1990$), 92$.

${ }^{284}$ Sheriff, Fragonard, 93.
} 
party departs. This reiterates the scene as an act of early courtship, and the partaking of the hot beverage by the couple is an important aspect of it.

\section{Beverages and Family Values}

As previously noted, chocolate had dual associations as both erotic or an aphrodisiac while at the same time thought of as a nutritional drink. The duality of chocolate's associations reflects the ways in which Lancret utilized hot beverages in his paintings. The two previously discussed paintings, Le matin and Le petit déjeuner avant la chasse, both contain sexual associations, while another painting by Lancret, A Lady and Gentleman with Two Girls in a Garden, depicts a familial scene of aristocratic refinement. Perhaps this painting is the end result of the sexual exploits of the chateau Marly-le-Roi overdoors.

Slightly later than the two previously discussed paintings, A Lady and Gentleman with Two Girls in a Garden (figure 106) is often cited by scholars as Lancret's most mature painting and his crowning achievement as an artist. ${ }^{285}$ The work depicts a lady, fashionably dressed, in a garden setting holding a spoon of liquid for one of the small girls standing next to her. Another young girl stands between the seated lady and the girl in yellow while a seated man looks at the scene from further behind; he holds a silver tray on which another cup and saucer sit. Meanwhile, a male servant holding a silver pot is in the process of pouring the contents into the empty cup. Unlike the previously discussed paintings in which the hot beverage was used to further the sexual nature of the scenes,

${ }^{285}$ Holmes, Nicolas Lancret: 1690-1743, 96. 
this painting depicts the familial side of beverage drinking and the instruction of small children.

Advancing this theory of the educational aspects of hot beverages, a doll has been cast aside in favor of receiving instruction from the mother about polite behavior in the central foreground of A Lady and Gentleman with Two Girls in a Garden. As scholar Woodruff D. Smith points out in his essay, "Tea and the Middle Class,"

a principal function of the family was educating children to become civilized adults able to take on their social responsibilities. One of the ways in which families performed this function was by trying to structure children's play as a kind of role-performance, a rehearsal for the rituals of adult life..$^{286}$

Therefore, one future duty for children, child-rearing as indicated by the doll, is cast aside for the more immediate skills of manners and sociability. The mother is quite literally giving the little girl a taste of what to expect when she is old enough to join respectable society.

Based on the form of the silver vessel, the beverage being drunk is either chocolate or coffee. However, while further analysis of the silver vessel could possibly lay the confusion to rest, the painting itself hinders additional investigation, as the top of the vessel is not visible. Foremost in the coffee versus chocolate debate with respect to this work is Mary Tavener Holmes, who, in her 1991 publication, notes the name of the painting as A Lady and Gentleman with Two Girls in a Garden (Cup of Chocolate). However, she argues that the type of silver vessel the servant holds is a coffee pot and that the title is a misnomer. Furthering her assumption, in her 2006 work, Nicolas Lancret: Dance before a Fountain, she titles the work as A Lady in a Garden taking

\footnotetext{
${ }^{286}$ Woodruff D. Smith, "Tea and the Middle Class" in Steeped in History: The Art of Tea, ed. Beatrice
} Hohenegger (Los Angeles: The Fowler Museum at UCLA, 2009), 146 
Coffee with Some Children. Holmes' conclusions are based on the 1742 mention of the painting in the Salon as "une Dame dans un Jardin, prenent du Caffé avec des Enfans."

Continuing this discussion of chocolate versus coffee, while chocolate was drunk by the aristocracy, it was most commonly taken in the morning and in the boudoir. ${ }^{288}$ It was not consumed regularly by children in France until the nineteenth century. ${ }^{289}$ While coffee was the beverage of the masses in eighteenth-century France, the sumptuous setting of the garden and the luxurious costume of the woman and children may lead the viewer of this tableau du mode to assume that its participants could afford to drink chocolate. Conversely, the categorization of the beverage as coffee is furthered by the depiction of the cups which do not appear to have handles, advancing their classification as coffee cups, since tea has been ruled out by the form of the silver pot. Furthermore, the shape of the cups is reflective of the wide and shallow form of the tea cup, which was also utilized for coffee. Frances Gage pointed out that the sucrier, or sugar bowl, on the silver tray would not have been served with chocolate, so the beverage must be coffee. ${ }^{290}$

In the instance of A Lady and Gentleman with Two Girls in a Garden, scholars have suggested that Lancret was responding to a painting by his contemporary, Boucher. Boucher's 1738 painting Le Déjeuner contains many of the same elements as Lancret's painting, though set in a domestic interior similar to the one seen in Le Matin but lacking sexual references. Le Déjeuner (figure 107) depicts a silver-bellied pot with a handle held

${ }^{287}$ L'Académie Royale, Explication des Peintures, Sculptures, et Autres Ouvrages de Messieurs de L'Académie Royale (Paris: Jacques Collombay, I. Imprimeur du Roy, 1742), 14, no. 50.

${ }^{288}$ Schivelbusch, Tastes of Paradise, 91.

${ }^{289}$ Schivelbusch, Tastes of Paradise, 93-95.

${ }^{290}$ Colin B. Bailey, The Age of Watteau, Chardin, and Fragonard: masterpieces of French genre painting (New Haven: Yale University Press, 2003), 154. 
by a standing man. Two women are seated on either side of a small table, one holding a small child on her lap, the other turning to look at another child in the right corner of the painting. On the table between the women are five cups and a sugar bowl. The silverbellied pot gives the viewer little clue as to the beverage in service since the top is not shown and there is apparently no sign of a moulinet. The beverage service looks to be simple white porcelain or earthenware; however, the condition of the painting does not allow for further analysis as the paint is very noticeably cracked. Despite this, the form of the cup does give reference to the beverage as that of chocolate, due to the taller, slimmer depiction of the cup with no handle, following the tradition of the painting, which has long been thought to depict a chocolate service. A sugar bowl like the one Gage identified in A Lady and Gentleman with Two Girls in a Garden, however, sits on the table indicating that the beverage must be coffee. Also visible in the painting is a teapot on the shelf to the left of the mirror and the small table on which the beverage set sits resembles the table depicted by Lancret in La Toilette.

The recent exhibit at the Musée Cognacq-Jay describes Boucher's Le Déjeuner as a family scene in which coffee is used to teach children about taste. ${ }^{291}$ Much like the woman offering the girl a taste of her coffee in Lancret's A Lady and Gentleman, the seated woman on the right of the painting entices the young girl with a spoonful of coffee. The girl will have to discard her doll and toy horse to partake in the lesson on

\footnotetext{
${ }^{291}$ Herda-Mousseaux, « Thé, café ou chocolat ? » 24 ; si l'une des fillettes des représentées a presque déjà la cuillère en bouche, c'est vers la deuxième que les regards convergent depuis une cafetière chaud posée sur le cheminée, protégée d'un linge sa mère lui tendent comme une invitation une seconde cuillère. Le caractère de la scène souligne l'importance accordée à l'éducation du gout de l'enfant par les familles aisées, argument en faveur de la reconnaissance de sa place en tant qu'individu parmi les débats intellectuels du XVIIIe siècle. La catégorie sociale des personnages est mise en valeur par un intérieur rocaille «à la mode » où se mêlent des objets d'importation, des pièces de service en porcelaine orientale et une Bouddha. »
} 
taste much the same as the young girl whose discarded doll is seen in the foreground in Lancret's painting. Both paintings depict the same sort of educational experiences, albeit in very different settings, that were a required part of elite sociability and refinement.

Herda-Mousseaux has noted that since their introduction into French society, "the exotic beverages acquired a fundamental role in the daily lives of the elite within a few decades." As the decades progress the three beverages diverged into very different uses. Chocolate and tea retained their elite associations, while coffee quickly became the drink of the masses. ${ }^{292}$ In many ways, Lancret's depictions of coffee, tea, and chocolate mirror the very different tracks these beverages took in their democratization. A Lady and Gentleman with Two Girls in a Garden seemingly prefigures Rousseau's emphasis on the role of mothers in the education of children, especially young girls, which were developments that took place in the latter half of the century.

In Lancret's images that depict coffee, tea, or chocolate, the artist not only depicted the everyday activities of the aristocracy or wealthy financiers but was able to connect the images of beverage consumption to larger issues such as the emerging modern French identity and globalization through the display and consumption of exotic beverages and the imported objects needed to consume them. In this way these paintings were both objects for and signs of conspicuous consumption; they prefigured, depicted,

\footnotetext{
${ }^{292}$ Herda-Mousseaux, « Thé, café ou chocolat ? » 28 ; «Images symboliques d'un univers où intimité et sociabilité confèrent leur place aux individus, les boissons exotiques acquièrent en quelques décennies un rôle fondamental dans le quotidien des élites. Bien que considérées initialement comme formant un trio indissociable, elles vont connaitre au cours du XVIIIe siècle français trois destins distincts. Le chocolat, rapidement attaché à la cuisine, conserve une valeur gourmande ; le thé pratique élitaire forte à compter des années 1760 , conserve ce statut dans l'iconographie tardive ; le café se singularise rapidement, certains contemporains rapportant une folie du café lacté dans le Paris prérévolutionnaire, impliquant par voie de conséquence fraude et recherche de produits de qualité. Moment déterminant dans la gastronomie et l'art de vivre «à la française », le siècle des Lumières a inscrit durablement les aventures du thé, du café et du chocolat dans le quotidien de tous les Français. »
} 
or displayed the literal consumption of commodities having already been purchased or devoured.

Furthermore, this fashionable display is characteristic of the tableaux du mode that exudes extravagance and the ease of leisure time. The subjects and objects depicted in these paintings, not limited to the beverage sets, exude the trappings of luxury and carefree living that was part of the performance of the everyday. Reiterating Hellman, these acts of leisure were by no means simple, but rather carefully controlled bodily comportment and socially proscribed interactions of individuals which required knowledge, refinement, and grace. These were the characteristics of honnêteté and politesse. The paintings by Nicolas Lancret in which the artist included fashionable hot beverages can be included in this idea of the 'work of leisure' because they depict the social roles of the aristocracy and the importance of leisure in their everyday lives.

Depending on the viewer's identification of a particular beverage being drunk in the scene, the hot beverages and the objects used in their service are not only emblematic of aristocratic leisure but help to further the sexual and educational subject matter of their respective paintings. Coffee, tea, and chocolate were cultural catalysts in many aspects. They either furthered the global outlook of France and its citizens, were used as a means of aristocratic conscious consumption, or used for educational lessons in taste and social refinement. As items for consumption, however, they also played into the aristocracy's ability to set itself apart from the rising bourgeoisie. Nicolas Lancret incorporated a hot beverage into genre scenes linking the beverages to ideas of French identity. Along with these beverages, other food items were included in paintings depicting the hunt, a pastime 
that has long been associated with noble French identity; these paintings are hunt luncheons and are examined in the following chapter. 


\section{Chapter Four - The Hunt Luncheons}

\section{Overview}

More than any other artist of the eighteenth century, Nicolas Lancret was the main proponent of this new hunt luncheon genre, completing at least six paintings that fall into this category. The briefly discussed Le repas au retour de chasse (figure 46 ) in the Louvre contains all or most of the required elements of a hunt luncheon painting, thus it can be considered to be one. The painting depicts horses, hunting dogs, and figures in hunting costume picnicking in a vast landscape. While this work is more representative of Lancret's earlier production period and the influence of Watteau's languid, fluid brushstroke, later hunt luncheons painted by the artist are emblematic of his break in figural style and size from the elder artist. Additionally, the iconography of these works lends itself to the subject matter of the paintings in a way that Watteau's paintings did not display. Not only are the food items on display in Lancret's hunt luncheons often identifiable objects, they are central to the subject matter of the paintings. Lancret also received patronage from the king of France, something Watteau never achieved in his short career, though it is unclear that he ever sought out royal commissions.

This chapter addresses images of dining in the context of the aristocratic ritual of the hunt. First, I will examine French texts that discuss hunting, exploring the social and historical circumstances that engendered these paintings; this is followed by a discussion of the objects themselves. These paintings typically depict the act of dining that occurred during the hunt and feature both men and women in a rural or rustic landscape setting. 
More often than not, these hunt luncheon paintings were less about the act of the hunt and more about the societal conventions that accompanied it during the period.

Firstly, I discuss the French traditions of the hunt is briefly explored to both contextualize the subject matter of the paintings and their aristocratic viewing context. The development of the hunt luncheon paintings follows as a means to examine Lancret's ingenuity in formulating a new genre in French art before the evaluation and interpretation of the paintings that fall into this category. This dissertation offers an iconographical interpretation of the paintings and an investigation of their place in Lancret's career, his artistic developments, and the art market. Lancret saw the success of Watteau's fêtes galantes and used Watteau's formula of landscape and aristocratic social pastimes to create a new type of genre painting - the hunt luncheon.

\section{French Traditions of the Hunt}

The right to hunt had been restricted to the king and nobility since 1515 . Others were given permission to hunt based on their seigneurial titles and landholdings. There were, however, exceptions to these rights that allowed locals to hunt small game and birds of prey. ${ }^{293}$ Prior to the eighteenth century, hunting was not just seen as a noble activity, but also as an exercise in readying men for war. Monsieur d'Yauville noted that the hunt taught men courage, how to handle horses and arms, as well as how to deal with fatigue. ${ }^{294}$ When the relationship between hunting and training for battle lessened, the

\footnotetext{
293 Jérôme Fromageau, "Droits de chasse et édits royaux" in De Chasse et d'Épée : Le décor de l'appartement du roi à Marly, 1683-1750 by Musée-Promenade Marly-Le-Roi-Louveciennes (Paris : Éditions L'Inventaire, 1999), 104-107.

${ }^{294}$ Monsieur d'Yauville, Traité de vénerie (Paris : Imprimerie Royale, 1788), 2.
} 
new relationship of the hunt as a civilizing process replaced the aspect of knightly combat training. Hunting became a complex social ritual that involved ideas of politesse and honnêteté which were means of political and social control established under Louis XIV. ${ }^{295}$ Politesse simply refers to the civility or courtesy that a person exhibits, their social graces or polite manners. Honnêteté however, is much more complex. It involved the adoption of the persona of an ideal courtier and selfless service to the crown. Also included are politesse, fashion, and artful adornment. ${ }^{296}$ Echoing the re-categorization of the hunt from military endeavor to that of polite society, Plax has argued that the hunt was an act of sociability since it depended on cooperation, conviviality, friendship, and politesse instead of competition. Furthermore, she notes that, "Over the course of time, the military justifications of the hunt gave way to the hunt as noble diversion that allowed the participants to display their knowledge of the rules and rituals." 297 These rules and rituals were specific to the French aristocracy and a way for them to gain favor with the king through their display of politesse and honnêteté.

The most prestigious of the noble exercises of the hunt was the grand chasse, also called the grande chasse à courre, chasse à courre, or la chasse reglée, in which a stag was the prey pursued by packs of dogs. When the stag was brought to bay, or cornered without means of escape, it was typically slain with sword or spear. This type of hunt was an essential part of life at royal châteaux. The petite chasses were just as common, and the prey included boars, wolves, deer, hares, and certain types of birds. They were a less

\footnotetext{
295 Michael S. Aradas, "The Etiquette of Social Violence: Hunting and Nobility in Early Modern France" (Order No. 3043698, Purdue University, 2001), http://proxy.mul.missouri.edu/login?url=https://searchproquest-com.proxy.mul.missouri.edu/docview/304724069?accountid=14576, 9.

${ }^{296}$ Plax, Watteau and the Cultural Politics of Eighteenth-Century France, 112-113.

297 Julie Anne Plax, "Fêting the Hunt in Eighteenth-Century Painting," in Artistes, savants et amateurs : Art et sociabilité au XVIIIe siècle (1715-1815), ed. Jessica Fripp et al (Paris: Mare et Martin, 2016), 129.
} 
noble category of hunts that included using a gun, nets, traps, or other means. Still other petites chasses were less regulated and not considered noble; these were the hunts of the common people in which the prey included rabbits, other pests, and birds such as hawks and pigeons.

The grande chasse and the petite chasse could last anywhere from an hour and a half to three hours or more than six depending on the animal being chased, the enthusiasm of the dogs, the stamina of the hunting party, and the ability of the game to elude its pursuers. ${ }^{298}$ The chase opened with the assembly of the hunting party at the rendez-vous which typically took place at a carrefour, or crossroads, of which there could be numerous carefully mapped out throughout the hunting grounds. The rendez-vous was ideally located at "some beautiful place under trees, near a fountain or stream." 299 These rendez-vous sites at the carrefours were often used for meals and breaks and were sometimes furnished with stone tables and benches. ${ }^{300}$ Louis XV built grand pavilions at his numerous châteaux that served similar functions as meeting places before, during, and after the chase. The princes de Condé had numerous rendez-vous sites, one with a table designed by Andre Le Notre that was used for serving a cold lunch during the hunt. ${ }^{301}$ Lunch was often carried by the hunters or their entourage; although some of the petites chasses did not require it as Jean-Baptiste-Jacques Le Verrier de la Conterie noted in his

\footnotetext{
${ }^{298}$ Vincent Droguet, Louis XV à Fontainebleau (Paris: Réunion des musées nationaux, 2016), 189 ; Alfred and Jeanne Marie, Versailles au temps de Louis XV (Paris : Imprimerie Nationale, 1984), 395 ; Tony Burand, Connaissance et Pratique de La Chasse (Paris : Éditions Denoël, 1967), 397 ; Jacques Barrat and Arnaud Fréminet, La vènerie française : un patrimoine d'avenir (Paris, Bibliothèque des introuvables, 2007), 121.

${ }^{299}$ Jacques de Fouilloux, La Vénerie (Paris : Chez Abel l'Angelier, 1601), 35 ; «quelque beau lieu sous des arbres, auprès d'une fontaine ou ruisseau. »

${ }^{300}$ Barrat and Fréminet, La vènerie française, 72.

${ }^{301}$ Musée Condé, Chasse à courre, chasse de cour : fastes de la vénerie princière à Chantilly au temps des Condés et des Orléans, 1659-1910 (Tournai : Renaissance du livre, 2004), 128.
} 
treatise L'école de la chasse aux chiens courants: "As for hunting hare, you do not usually carry your lunch." ${ }^{302}$ For longer hunts such as the grande chasse, cold meats were typically carried by members of the party for lunch along with bread and wine. ${ }^{303}$

For the larger hunts, the rendez-vous before the hunt also served as a place to eat while waiting on the rest of the hunting party to gather. According to Gaffet's Nouveau traité de venerie, during the hunt it is up to the Seigneur to provide dinner for the hunting party at the rendez-vous. ${ }^{304}$ While Gaffet uses the term "diner" to describe the meal, he is discussing the convening of the hunting party and the order and assembly of the chase, so the term should not be taken literally. The hunt typically started about ten or eleven in the morning after the party received its instructions. ${ }^{305}$ While waiting for the rest of the party to convene the hunters eat, drink, and socialize, as depicted by Lancret in the previously discussed La petit déjeuner avant la chasse. ${ }^{306}$ Jacques de Fouilloux’s 1561 La Vénerie recorded one such meal at the rendez-vous as including "hams, smoked tongues of beef, snouts and ear of swine, belly, pieces of seasoned beef, carbonnades [beef and onion stew], Mageance hams, pâtés, [and] cold veal loin." ${ }^{307}$

\footnotetext{
302 Jean-Baptiste-Jacques Le Verrier de la Conterie, L'école de la chasse aux chiens courants (Paris : Emile Nourry, 1932), 64 ; «Comme pour chasser le lièvre on ne porte ordinairement pas à déjeuner. » ${ }^{303}$ Robert Salnove, La Vénerie royale (Paris : A de. Sommaville, 1665), 134.

${ }^{304}$ Antoine Gaffet, sieur de La Brifardière, Nouveau traité de venerie contenant la chasse du cerf, celles du chevreuil, du sanglier, du loup, du lievre et du renard (Paris : Nyon, Damonneville et Guillyn, 1750), 92.

${ }^{305}$ Salnove, La Vénerie royale, 134.

${ }^{306}$ Fouilloux, La Vénerie (1561), 35 ; Lors le roi, ou le seigneur, avec ceux de sa table, étendront leurs manteaux sur l'herbe, et se coucheront de cote dessus, buvant, mangeant, riants et faisant grande chère. Et s'il y a quelque femme de réputation en pays qui fasse plaisir aux compagnons, elle doit entrer allègre en ses passages et remuement de fesses, attendant le rapport à venir. Puis quand tous les veneurs seront arrivés, ils feront leur rapport, et présenteront leurs fumées au roi ou au seigneur à qui ils feront, les uns après les autres, en racontant chacun de ce qu'il aura vu. »

${ }^{307}$ Fouilloux, La Vénerie (1561), 35 ; «jambons, langues de beuf fumes, groings et oreille de pourceau, cervelat, eschinée, pièces de bœuf de saison, carbonnades, jambons de Mageance, pastez, longes de veau froides. » The term Mageance is probably a reference to a Mayence ham or one that comes from Mainz, originally a Roman fort town in the Rhineland. See Toussaint-Samat, A History of Food, 410.
} 
Not all meals were taken on the hunting grounds. The dinner after the conclusion of the hunt was often taken in the château and was attended by the hunting party. In 1785 , a hunt dinner comprised of "leg of lamb with garlic, lamb shoulder, pigeons, fricasseed chicken, two roast chickens, a roasted veal shoulder, a flask of soup, and rabbit and cheese salad sandwiches" was served by the comte de Saxe. ${ }^{308}$ On other occasions the comte served various cuts of deer, veal loin and shoulders, mutton shoulders, roast chickens, beef tongue, and hares among other meats. Salvadori has theorized that the meat-laden meals were meant to replenish the strength and carnivorous forces of the hunters. $^{309}$

Not only did the grande chasse including the hunters, servants, and dogs, but it also had observers, including women, who followed the hunting party through the landscape. Plax has noted that, "women provided a necessary audience for the display of male prowess" during the hunt. ${ }^{310}$ Women had long participated in falconry and lesser hunts; Louis XV's own daughters were outfitted with their own hunting crew, dressed in green hunting garb, and allowed to hunt in the woods at Verrières under the direction of the Marquis de Dampierre, Marc-Antoine de Dampierre (1676-1756). ${ }^{311}$ Typically Louis' daughters hunted for hare or deer either on horseback or following the pack in a carriage. ${ }^{312}$ Salvadori notes that La Gazette reported on April 16, 1635 that, "after a snack, the Queen [Anne of Austria] and all of her ladies went out on horseback in the park to watch the fox hunt by the King's dogs...this entertainment was only for the

\footnotetext{
308 Philippe Salvadori, La chasse sous l'Ancien Régime (Paris : Fayard, 1996), 148-149.

${ }^{309}$ Salvadori, La chasse sous l'Ancien Régime, 148-149.

${ }^{310}$ Plax, "Fêting the Hunt in Eighteenth-Century Painting," 133.

${ }^{311}$ Brigitte Chabrol, Encyclopédie de la vènerie française (Paris : O. Perrin, 1961), 20.

312 Salvadori, La chasse sous l'Ancien Régime, 201.
} 
Queen and the ladies." ${ }^{313}$ The duchesse d'Orléans, mother of Philippe d'Orléans followed all of the hunts during the last years of Louis XIV's reign either on horseback or in a carriage. ${ }^{314}$ For French noble women, the hunt was "a physical symbol of their leisure, bloodline, and power." 315

Hunting was always a right of noble women and the visual arts displayed this through countless medieval manuscripts lushly decorated with images of women participating in the hunt. Two variations of women hunting were simultaneously produced in medieval manuscripts, but both are defined as a chasse d'amour. The variation between the two is that in one version women were the huntresses and in the other they were the prey. ${ }^{316}$ Still, during the eighteenth century, women were often relegated to the sidelines of paintings depicting the hunt and not shown as active participants in the noble pastime. Michael Aradas cites the male domination and control of women hunting as a cause of the lost control of hunting rights to commoners. ${ }^{317}$ Furthermore, Aradas has theorized that images of huntresses were morphed into depictions of Diana during the sixteenth century, potentially due to concerns of commoners infringing upon noble (male) rights to the hunt, thus making the huntresses erotic figures of male consumption instead of possible competitors in sport. ${ }^{318} \mathrm{He}$ states, "In a short seventy-odd years, women were iconographically transformed from active

\footnotetext{
${ }^{313}$ Salvadori, La chasse sous l'Ancien Régime, 208 ; « après la collation, la Reine et toutes les dames sont allées à cheval dans le parc voir chasser le renard aux chiens de Roi, qui ont fort bien chassé, et comme ce divertissement n'étoit que pour la reine et les dames, il n'y avoit aussi qu'elles à cheval. »

${ }^{314}$ Joseph-Anne-Emile-Edouard, baron Dunoyer de Noirmont, Histoire de la chasse en France depuis les temps les plus reculés jusqu'á la révolution (Paris, Ve Bouchard-Huzard, 1867-1868), 211.

315 Aradas "The Etiquette of Social Violence," 223.

316 Aradas, "The Etiquette of Social Violence," 216.

${ }^{317}$ Aradas, "The Etiquette of Social Violence," 217.

${ }^{318}$ Aradas, "The Etiquette of Social Violence," 4-5.
} 
participants in the hunt ritual into mere naked ornamentation, present only for voyeuristic titillation." ${ }^{319}$ Aradas notes that despite her role as the goddess of the hunt, Diana was converted into a reclining voluptuous nude as opposed to a vigorous huntress. ${ }^{320}$ While the act of the hunt had always carried connotations of courtship and seduction, by the eighteenth century it became synonymous with sexual encounters. ${ }^{321}$

Despite the lesser role of women as active participants of the hunt in paintings, their role in genre scenes relating to the hunt is crucial. Watteau depicted women joining the hunting party in Rendez-vous de Chasse (figure 49) and Parrocel, a slightly older artist, painted works that show women as active hunters and women on horseback during the latter part of the seventeenth century (figure 108). Louis XV's own wife, Marie Leszczynksa (1703-1768), was depicted by the artist Jean-Baptiste Martin (1659-1735) en Amazone on horseback during a chasse au faucon and later Marie Antoinette (17551793) was painted in riding habit on multiple occasions by Joseph Krantzinger (ca. 17401772) and Louis-Auguste Brun (1758-1815). While the two royal women may not have participated in an actual hunt, the women in Lancret's paintings are a necessary part of the festivities.

\section{The Development of the Hunt Luncheon}

In the 1730 s the young Louis XV helped to popularize a new genre in eighteenthcentury Rococo art, the hunt luncheon. This short-lived new genre combined the densely populated out-of-doors forest-like settings of Antoine Watteau's fêtes galantes, with the

\footnotetext{
319 Aradas, "The Etiquette of Social Violence," 217.

${ }^{320}$ Aradas, "The Etiquette of Social Violence," 4-5.

${ }^{321}$ Aradas, "The Etiquette of Social Violence," 235, 277.
} 
meticulous, luxurious, and intimate details of fashionable society depicted in tableaux de mode popularized by Jean-François de Troy (1679-1752). ${ }^{322}$ While many scholars have discussed this new type of painting in passing, only Holmes has tried to define it or describe its characteristic elements. Holmes has also noted that the theme of "the hunt picnic... was virtually invented [by Nicolas Lancret] in response to the King's obsession with hunting." 323 In her earlier publications on Lancret, the author discusses a few of the works with which this dissertation is concerned, but she only mentions these works as part of the larger trend towards genre paintings. In The Age of Watteau, Chardin, and Fragonard as well as French Painting of the Fifteenth through Eighteenth Century, scholar Frances Gage also addressed Lancret with respect to formulating the "hunt picnic;" however, her discussion is limited to the few pages allowed each catalogue entry. ${ }^{324}$ Holmes has also repeatedly noted that this genre is "resoundingly contemporary in costume and detail." 325

With the publication of the 2011 catalogue of French paintings by Stiftung Preussische Schlösser und Garten Berlin-Brandenburg, which covers the collections of Frederick the Great, Holmes furthers her assertion that Lancret "developed a general picture scheme for the theme of the hunt meal," identifying similar characteristics found in hunt luncheon paintings. ${ }^{326}$ Of these, Holmes states,

\footnotetext{
${ }^{322}$ For a discussion on de Troy and tableaux de mode see: Baxter, "Fashions of sociability in Jean-François de Troy's tableaux de mode, 1725-1738."

${ }^{323}$ Holmes, Nicolas Lancret, 1690-1743, 76. For more on the incredible size of Louis XV's hunting entourage see Plax, "Fêting the Hunt in Eighteenth-Century Painting," 130.

${ }^{324}$ Bailey, The Age of Watteau, Chardin, and Fragonard, 146, 152; Philip Conisbee, French Painting of the Fifteenth through Eighteenth Century (Princeton, N.J.: Princeton University Press, 2009), 288; Holmes, "Katalog: Nicolas Lancret," 591.

${ }^{325}$ Holmes, Nicolas Lancret, 1690-1743, 76.

${ }^{326}$ Holmes, "Katalog: Nicolas Lancret," 588: „Fur das Thema der Jagdmahlzeit entwickelte Lancret ein generelles Bildscheme."
} 
All hunters wear contemporary hunting clothes from tricorn [hats], decorated hunting coat(s) with high collars and waistcoats, a skirt or short pants with knee-length leggings and boots. Often this group is gathered around an unfolded white cloth on the ground, on which a pending country meal is being prepared - a pastry, bread and cheese, perhaps a hare. The food is served on silver or tin, with glass and occasionally porcelain. The sedentary group is usually behind a catch of trees, the view of the landscape opens out to one side of the painting. Servants serve the food, uncork the wine; horse- and doghandlers take care of the animals. There are always horses and dogs, which are often treated with humor and with affection: they are fed with biscuits, allowed to drink from glasses, lick plates, etc. Lancret aimed at shaping the hunt meal, emphasizing the contemporaneity [contemporary nature] and luxuriousness of the hunt. ${ }^{327}$

Moreover, the hunt luncheon paintings combine the outdoor setting, the ethereal lighting, and the characteristic vibrant color palette of Watteau's fête galante with the depictions of social trends and leisure time activities of the tableaux de mode. The view of the landscape that Holmes discusses is characteristic of Watteau's paintings as discussed in Chapter One. Additionally, occupants of a fête galante, tableaux de mode, and the hunt luncheons are often engaged in conversation or courtship. However, as noted by Holmes, specific to the hunt luncheon painting is the presence of hunting costume, food, horses, and hounds. ${ }^{328}$

In addition to all the features Holmes listed, I would further add that most of the paintings which can be characterized as hunt luncheons also include a hunting horn and a château or other architectural feature - the key items, locale, and accoutrement needed for the traditionally aristocratic pastime. While some of the paintings by Lancret depict

${ }^{327}$ Holmes, "Katalog: Nicolas Lancret," 588: „Alle Jäger tragen zeitgenössische Jagdkleidung aus Dreispitz, geschmücktem Jagdmantel mit hohen Manschetten und Westen, einem Rock bzw. kurzen Hosen mit knielangen Gamaschen und Stiefeln. Oft ist diese Gruppe um ein auf dem Boden ausgebreitetes weißes Tuch versammelt, auf dem ein landliches Mahl vorbereitet wird - eine Pastete, Brot und Käse, vielleicht ein Hase. Das Essen wird auf Silber oder Zinn angerichtet, mit Glas und gelegentlich Porzellan. Die sitzende Gruppe ist gewöhnlich von Bäumen hinterfangen, der Blick in die Landschaft öffnet sich auf einer der Bildseiten. Diener servieren das Essen entkorken den Wein; Pferde- und Hundeführer kümmern sich um die Tiere. Stets gibt es Pferde und Hunde, die oft humorvoll und mit Zuneigung behandelt werden: sie werden mit Keksen gefüttert, dürfen aus Glasern trinken, Teller ablecken etc. Lancrets Gestaltung der Jagdmahlzeit zielt darauf ab, Das Zeitgenössische und Luxuriöse der Jagd zu unterstreichen.“

${ }^{328}$ Holmes' criteria for hunt luncheon paintings was developed simultaneously to my own previous research, both projects having been finished in 2011; See: Williams, "Dining and Revelry in French Rococo Art." 
hunting guns, they were by no means always necessary, as the grande chasse and many of the petite chasses did not allow or require the use of guns. ${ }^{329}$ These hunt luncheon paintings use the ritual of the hunt to explore societal conventions associated with the sport. They are less about hunt and more about the conviviality of the people depicted; they seem to provide glimpse at social customs of the aristocracy, the hunt, and, more generally, the eighteenth century.

The hunt luncheon paintings by Nicolas Lancret also provide an idealized imagining of the foodstuff that may have been consumed by the participants of this social pastime. As Holmes notes, bread and wine are ubiquitous in these paintings; but rather than an association of the rustic or bucolic nature of these items, both were staples of French cuisine regardless of where one fell within the social strata of the ancien régime. Other included food objects that lend themselves to the rustic or bucolic atmosphere of the scene depicted. Pastries specifically exude these rustic connotations and will be discussed further below. However, the presence of cheese in any of the paintings by Lancret is questionable, and while hares may have been the prey of these hunting excursions on occasion, one has yet to be identified as the item being consumed by the participants in Lancret's paintings. Despite this, in many ways the food items confirm the wealth and social status of the people depicted.

Lancret completed paintings considered to be hunt luncheons as early as 1725 and continued to do so through the 1730s. The artist's final hunt luncheon was completed in 1740 , just three years before his death. His depictions of the subject stretched throughout

\footnotetext{
${ }^{329}$ For a further discussion on the use of guns during the hunt see Freund, "Men and Hunting Guns in Eighteenth-Century France."
} 
most of his artistic career. The first hunt luncheon, Le repas au retour de chasse, contains many of the characteristic subjects and style of Watteau. Le déjeuner de jambon and Le déjeuner dans le foret are paintings in which Lancret was still working out his own personal idiom. The final painting, Le repas de chasse, is evocative of the artist's mature production and shift away from Watteau's style.

\section{Le repas au retour de chasse $(\mathbf{1 7 2 5})$}

The painting Le repas au retour de chasse (figure 46) is the first painting in which Lancret combined a dining scene with the aristocratic pastime of the hunt. The painting meets all the criteria of a hunt luncheon with the exception that there is no hunting horn depicted. Le repas au retour de chasse borrows elements from Watteau, such as the fountain and screening of the trees, but again, the social activity of picnicking is wholly Lancret's subject matter, as is the composition and the scale of the figures in relation to the landscape setting. The artist has placed the grove of trees on the left of the painting with the architectural feature of the fountain depicted just off center. This leaves only a sliver of a deep background visible on the right side of the painting. On the left, a white tablecloth partially covers a stone table on which wine glasses, wine bottles, and a tray of peaches are set. Two servants appear to be having a conversation while a third holds a tray of glasses full of red wine. Another servant holds the reins of a horse, with two more horses depicted behind. A woman in blue holding a fan stands to the right of this servant, and she is gazing slightly over her shoulder at the rest of the group. A man in a brown coat stands gesturing widely with the butt of his rifle on the ground, barrel in his left hand. The seated group is composed of three more women and a seated man next to 
whom two dogs appear. The seated woman in yellow has her tricorn hat in hand, while the seated woman in pink still wears hers cocked to the left. All the women are wearing riding dress very similar to that of their male counterparts.

Interestingly, at least two of the four women, the seated woman in yellow and the standing woman in blue, appear to be wearing their hair down in a fashion like the men but not pulled back with a black bow. The woman in pink appears to have her hair cropped short and curled, as was the fashion. ${ }^{330}$ The seated woman in green may also have her hair down since the ringlets that frame her face are like those of the women depicted with long hair. The women's long hair may be a form of hunt masquerade; since their dresses are based on the male hunting outfits presumably their hair also followed suit. This type of transvestism was not uncommon during the eighteenth century but was usually reserved for royal fêtes and masquerades. ${ }^{331}$ The donning of the hair and dress inspired by masculine hunt fashions would then give the women credibility as participants in the ritual of the hunt.

This painting has received some recent scholarly attention in the 2014 exhibition De Watteau À Fragonard, les fêtes galantes at the Musée Jacquemart-André. In the catalogue entry for this work, Mary Tavener Holmes notes that the women depicted could not have participated in the hunt because they are wearing the delicate high-heeled mules that were fashionable at the time. ${ }^{332}$ Lancret has not depicted a carriage in the painting, however, so the question of how the women reached the picnic spot remains open as the

\footnotetext{
${ }^{330}$ Ribeiro, Dress in eighteenth-century Europe: 1715-1789, 110.

${ }^{331}$ For more on transvestism and masquerade in fashion prints see: Sarah R. Cohen, "Masquerade as Mode in the French Fashion Print" in The Clothes that Wear Us: Essays on Dressing and Transgressing in Eighteenth-Century Culture, ed. Jessica Munns and Penny Richards (Newark: University of Delaware Press, 1999) 174-207.

332 Christoph Martin Vogtherr and Mary Tavener Holmes, De Watteau À Fragonard, les fêtes galantes (Bruxelles: Fonds Mercator, 2014), 76.
} 
three horses depicted are too few for the four women, and the one visible saddle does not appear to be a woman's sidesaddle. However, it was common for women to follow the hunting party through the landscape while not actually participating in the hunt themselves.

Holmes has also suggested that one of the food items depicted is a "rustic meal of pâté en croûte and of bread;" however, the author does not specify which of the two pie or pastry-like objects is the pâté and leaves the other object unidentified. ${ }^{333}$ Presumably the pâté en croûte is the round pastry with the depressed center. The other pastry could possibly be a game pie; raised pies of this type were typically filled with game meat and served cold, an ideal meal for picnics. ${ }^{334}$ Furthermore, both pâté and pies carry connotations of being a rustic food, an implication that plays well with the locale of hunting excursions. ${ }^{335}$ Bread is strewn about on the tablecloth and wine is being served; as previously noted, both bread and wine were staples of French cuisine regardless of where one fell within the social strata of the ancien régime.

The presence of the tray of peaches, however, is a definite marker of the social status of the figures in the painting, as peaches had become important foodstuff in France only a century before. Peaches are Chinese in origin but were introduced to Rome by the Persians, so they are sometimes referred to as Persian apples. They may have been introduced to France through the Italian peninsula. Alternatively, peaches may have made their way to the European mainland through the Balkans. Whatever their means of introduction, peaches were grown by the Gauls in the early Christian era, were important

\footnotetext{
333 Vogtherr and Holmes, De Watteau À Fragonard, 76.

334 Joël Robuchon and Prosper Montagné, Larousse gastronomique: the world's greatest culinary encyclopedia (New York: Clarkson Potter Publishers, 2009), 786.

335 Robuchon and Montagné, Larousse gastronomique, 1089.
} 
cultivars during the Middle Ages, and gained greater social importance in the seventeenth century, when Louis XIV had some peach trees planted in the gardens of Versailles. ${ }^{336}$ Peaches are a summer fruit and were typically available in July and August; however, by the eighteenth century horticulturalists had learned how to force plant growth and production outside of normal growing periods. ${ }^{337}$ The ability to grow peaches out of season furthers the connection of the fruit with luxurious and excessive connotations, since they would have only been available to the wealthiest echelons of society. In Lancret's inclusion of peaches in Le repas au retour de chasse, the artist appears to conform to actual culinary practice, as according to Denis Diderot's Encyclopédie entry, peaches should be eaten raw. ${ }^{338}$ Food Historian Susan Pinkard has noted, in the course of the eighteenth century, cuisine based on fresh farm and garden products would become indelibly (if misleadingly) linked to the ideal of the simple and virtuous rural life as imagined by Rousseau. In reality, the modern French style of delicate cooking was expensive and exclusive, as its appeal was wholly dependent on access to an abundance of raw materials that were seasonal, perishable, and most readily available to the gentlemen farmers who produced them. ${ }^{339}$

The aristocratic diet was dependent upon meat, bread, a variety of fresh fruits (such as peaches), and vegetables. However, these fruits and vegetables were only available if the aristocrat had land or the means to purchase them from the market. Since many nobles during the eighteenth century were landless or impoverished, there was no guarantee that they would be able to purchase such items as was required by their positions. Therefore, Lancret's depiction of peaches was a representation of aristocratic ideals as opposed to a factual account.

\footnotetext{
${ }^{336}$ Miklos Faust and Béla Timon, "Origin and Dissemination of Peach" in Horticultural Reviews, Vol. 17, (1995), 338, 350-353

${ }^{337}$ Toussaint-Samat, A History of Food, 646; Wheaton, Savoring the Past, 126.

${ }^{338}$ Denis Diderot, Encyclopédie ou Dictionnaire raisonné des sciences, des arts et des métiers, volume 12 (Paris, 1765), 225, ark:/12148/bpt6k505440

${ }^{339}$ Susan Pinkard, A Revolution in Taste: the rise of French Cuisine (New York: Cambridge University Press, 2010), 76-77.
} 
Le repas au retour de chasse was fittingly owned by Louis XV's stable master, or premier écuyer, the Marquis de Beringhen, who presumably would have had access to peaches year-round, given his closeness to the crown. The Marquis also owned the previously mentioned series of the elements by Lancret. Le repas au retour de chasse's presumed pendant, Les Plaisirs de bain (figure 109), depicts a striking combination of contemporary genre scenes and traditional scenes of women bathing. ${ }^{340}$ Bathing scenes such as this were commonly depicted by artists in the guise of mythological paintings. As discussed by Aradas, images of Diana and her nymphs, Europa, and Persephone, or the biblical figures of Susanna or Bathsheba, are all thinly veiled excuses to depict nude women in the act of bathing. Again, however, Lancret has stripped Les Plaisirs de bain of allegorical or mythological references and replaced them with contemporary details in costume and leisure time activities. ${ }^{341}$

The leisure time activity of Les Plaisirs de bain is that of boating, which is not a common subject in Lancret's oeuvre. Lancret did complete another painting depicting boating entitled Le Départ pour Cythère (figure 110) which dates to 1719-20, placing it about five years before Les Plaisirs de bain. Lancret depicted a third boating scene in a later painting, Fête galante entre une terre et une rivière, which will be discussed further below. Both Les Plaisirs de bain and Le Départ pour Cythère fall into the earlier part of Lancret's career when he was heavily influenced by Watteau; this can be seen in the subject matter of the painting, which echoes Watteau's own famous rendition of Cythera.

\footnotetext{
${ }^{340}$ Lancret's other images of women bathing include: Four Times of Day: Evening, Holmes, Nicolas Lancret, 1690-1743, 93; Diana and Callisto, Holmes, "Katalog: Nicolas Lancret," 477; Summer, Wildenstein, Lancret, 71, pl 9; Pater, Baigneuses, Vogtherr and Holmes, De Watteau À Fragonard, 70.

${ }^{341}$ The painting Diana and Callisto is one of the few known mythological paintings by Lancret. Holmes, "Katalog: Nicolas Lancret," 477 ; Wildenstein, Lancret, 119, pl 173.
} 
The general composition of Watteau and Lancret's Cythera paintings is similar, as is the canopied boat and the pairing-off of the figures. In addition, in his reception piece for the Académie, Pèlerinage à l'île de Cythère (figure 1), Watteau depicted boating in the second version of Pèlerinage and again in another painting completed for Jean de Jullienne. The painting for Jullienne is part of an uncompleted series of the seasons, of which the Spring painting depicts boating as a leisurely pastime as opposed to an allegory of love or visit to a mythical island; though the pretext of courtship remains given that the figures are paired off. The similarities between Watteau and Lancret's paintings of Cythera are not surprising since Lancret's version was painted so early in the artist's career. As previously discussed, this was a period in which Lancret's production was reliant upon the older artist stylistically and in his choice of subject matter.

As previously stated, Les Plaisirs de bain is thought to be the pendant to Le repas au retour de chasse based on the 1725 Salon reference. However, the dimensions of the paintings do not suggest a pairing; they differ almost 4 inches in height $(9.7 \mathrm{~cm})$ and 12 inches in width $(30.5 \mathrm{~cm})$ with Les Plaisirs de bain being both taller and wider than Le repas au retour de chasse. Despite this, Marie-Catherine Sahut, Élisabeth Martin and Claudia Sindaco-Domas have argued that the two were a pair and Le repas was trimmed on the top and at the right at some point. Supposedly the work's original dimensions were more in line with Les Plaisirs. The authors note that the painting was cut down for unknown reasons sometime after 1783, when it was last mentioned in a sale catalogue after the death of its owner, and before the 1924 monograph on the artist by Georges Wildenstein. ${ }^{342}$

\footnotetext{
${ }^{342}$ Marie-Catherine Sahut, Élisabeth Martin, and Claudia Sindaco-Domas, "Le Repas de chasse et Les Plaisirs du bain de Nicolas Lancret," Techne, Numéro 30-31 (2009-10), 163-4.
} 
As with the size of the paintings, there have also been issues with the dating of the pair. Holmes and other scholars have very recently proposed that Le repas au retour de chasse was the painting mentioned in the 1725 Salon exhibition as opposed to the painting in the collection at Sanssouci. ${ }^{343}$ The redating of the paintings is based on the Salon mention which states, "Return from the hunt, 4 feet wide by 3 , where we see various riders and ladies in hunting dress having a snack. Women at the Bath. View of the Porte S. Bernard, same size." ${ }^{344}$ This new date is predicated on the mention of the bathing scene, which scholars now believe to be the pendant to Le repas. ${ }^{345}$ If the date of 1725 is to be believed, it places the painting almost a decade before its previously accepted date of 1737. The new dating does appear to coincide with Lancret's artistic and compositional developments. While the figures in Le repas do appear larger in relation to the painting's background this is due in part to the cutting down of the painting as it no longer contains as much surrounding scenery. This surrounding scenery would have presumably created a scale that more readily conforms to Watteau's paintings, such as Rendez-vous de Chasse or Lancret's L'autumn, completed around the same time. The figures are, however, representative of Lancret's style and the poses are his own design.

\section{Le déjeuner de jambon (1735)}

While Le repas au retour de chasse is part of Lancret's earlier artistic production in which he still relied heavily on Watteau, Le déjeuner de jambon (figure 111) was

\footnotetext{
${ }^{343}$ Vogtherr and Holmes, De Watteau À Fragonard, 74-75; the catalogue entries for this work and its pendant have the dates of before 1725 .

${ }^{344}$ Wildenstein, Le Salon de 1725, 46. "Retour de chasse, de 4 pieds de large sur 3, où l'on voit divers cavaliers et des Dames en Amazones qui font collation. Bain de Femmes. Vûë de la Porte S. Bernard, même grandeur."

345 Sahut, Martin, and Sindaco-Domas, "Le Repas de chasse et Les Plaisirs du bain de Nicolas Lancret," 163.
} 
painted ten years later and displays a new vibrancy of subject matter and stylistic differences. While Le repas au retour de chasse and Le déjeuner de jambon are similar in relation to their subject matter, Le déjeuner marks a break from Watteau's influence in scale. The figures are much larger and more prominent in comparison to those in the vast majority of Watteau's paintings. The figures themselves are imbued with a vivacious quality not commonly found in the elder artist's works. This painting is the only hunt luncheon that that contains Posner's "comic air or explicitness" that seems to suggest Lancret's personal appreciation for such subject matter. ${ }^{346}$

Lancret's painting Le déjeuner de jambon is the first of these hunt luncheon paintings that was commissioned for Louis XV. Because of this, it has received more scholarly attention than most of the other hunt luncheon paintings by the artist. While the Lancret does retain some of the compositional elements often found in Watteau's works, such as the partial wall topped with a statue and the metal framework arbor, as with Le repas au retour de chasse, the figural composition is definitively Lancret's own. The figures appear larger in relation to the pictorial space and the landscape depicted is not as vast as those in Watteau's paintings. While the screening of the trees is still reminiscent of Watteau, Lancret denies a view into the landscape by positioning his figures at the center of the break in the tree line. Additionally, the focus of the painting is on that of the meal that was or is being taken by the party. While Watteau depicted diners in his paintings influenced by Northern traditions, the act of dining was never the central focus as it is here.

${ }^{346}$ Posner, Antoine Watteau, 27. 
Lancret focuses the subject on dining by placing the prominent round table at the center of the canvas. The table is laden with remnants of a meal in progress; scattered partial loaves of bread, a ham, crayfish shells, bottle coolers, plates, and silverware are all strewn about the table. In front of the table, the foreground is littered with empty bottles, broken plates, copper basins, an overturned chair, two dogs, and a single cat. The overturned chair acts as an opening, allowing the viewer to enter the physical space of the painting and partake in the revelry of the party. The obvious inebriation of the party is reinforced by the scattered empty bottles in the foreground, but also by the ruddy, jovial faces and the overtly brash actions of the central figure who stands with one foot on the table, the other presumably on his chair. The laurel wreath on his head echoes traditionally representations of Bacchus, or even Watteau's previously discussed L'Automne or L'amour au théâtre françois, making the man out to be a modern, eighteenth-century version of the god of wine.

The equation of the central male figure with Bacchus is furthered by the inclusion of the statue atop the partial wall which is identifiable as a satyr and a feline; the feline is presumably a panther, a familiar of Bacchus. The god is typically shown wearing a panther skin or is often seated in his chariot being pulled by large felines. Additionally, according to mythology satyrs typically appear alongside Bacchus or Dionysus since they were his male companions. The satyr statue holds a bunch of grapes above his head and is in the process of eating them. The grapes further relate the satyr to Bacchus and the scene occurring below. The inclusion of statuary that advances the subject matter of the scene is another device that Lancret borrowed from Watteau. Watteau used statues as symbolic motifs in numerous paintings, most often depicting Venus and Cupid to convey 
the amorous nature of the scene taking place. In including the figures of the satyr and the large feline, Lancret uses his statuary to reiterate the identification of the central man as a modern Bacchus, making the statuary more than just mere decoration.

The inclusion of references to Bacchus in the painting imbues it with a sense of excess, frivolity, and luxury that is also furthered by the food items depicted: peaches, crayfish, and ham. The tray of peaches presumably being brought to the table signifies the end of the meal, but also the high social status of the participants of the scene given the seasonal availability of the fruit. Since peaches were grown in the greenhouses of Versailles, they would have been readily available to Louis XV regardless of the season. Peaches are similar to the fruit of the Original Sin, and as such have long held connotations of immorality. ${ }^{347}$ The conflation between the peach and the apple as the fruit of the Original Sin, or of sin more generally, is also apparent in the French language; the word for peach in French is differentiated from the word for sin by the accents, the accent circonflexe in the word for peach, pêche, and the accents aigu in the word for sin, péché. The conflation of the peach with Eve can also be furthered by Lancret's inclusion of a single female figure in the painting; she could be a modern, eighteenth-century Eve, possibly responsible for the moral failings of the men depicted.

Lancret also depicted crayfish in this painting, which were a fairly rare and luxurious item and had the pejorative connotations of extravagance or the sin of gluttony. The shellfish are both on the table and on a tray which was presumably cleared from the table by the servant holding it to the left. Crayfish also advance the sinful nature of the scene since crustaceans represent sin or the devil because they walk both forwards and

${ }^{347}$ Malaguzzi, Food and feasting in art, 227. 
backwards, much like Satan. ${ }^{348}$ During the seventeenth and eighteenth century, crayfish regularly appear on the menus of fashionable society, again presumably as a delicacy only the most affluent individuals would have been able to obtain. ${ }^{349}$ Similar to other seafood items, crayfish die fairly quickly when removed from water and would not have been able to travel far from their freshwater source. Like other mollusks and shellfish, if crayfish die before they are cooked they are no longer safe to be eaten. The expense of quick travel from their harvesting to their place of consumption, and the amount of them lost during their voyage, would have made them an expensive and luxurious item.

Additionally, the socio-historical associations of the ham depicted in the center of the table advances the excessive and gluttonous quality of the scene at hand. Ham has been produced in France since antiquity, when the Gauls were renowned for their ability to make this salted, cured meat which was highly prized by the Romans. Ham also carries social connotations of gluttony, since the pigs that ham is made from seemingly never cease eating. The idea of gluttony is further conveyed in this work through the large bellies of the men, the empty wine bottles, and the overturned chairs. Ham can also be said to more generally represent sin since it is made from pigs, long believed to be unclean animals according to early Christian writings. ${ }^{350}$ However, ham was neither seen as an elite food, nor a humble one, but was widely consumed. ${ }^{351}$ The ability to preserve pork to create ham meant that it could be enjoyed year-round and as such was presumably not as expensive as fresh meat during the winter and lean harvest years. Ham was also easily transported, making it ideal for picnics, traveling, and meals during the

\footnotetext{
${ }^{348}$ Malaguzzi, Food and feasting in art, 177.

${ }^{349}$ Robuchon and Montagné, Larousse gastronomique, 318.

${ }^{350}$ Malaguzzi, Food and feasting in art, 141.

${ }^{351}$ Wheaton, Savoring the Past, 126.
} 
hunt. During the eighteenth century, ham became fashionable as an hors d'oeuvre and a picnic food, as seen in this painting. ${ }^{352}$

In these instances, the peaches, crayfish, and ham appear to reinforce the identification of food with those consuming it, their social class, and long-standing historical connotations. Surely the eighteenth-century viewers of these works would understand all of the various underlying meanings contained within the images of these food items and would have possibly applied these to the larger subject matter of the painting. The associations of all of these food items is that of sin and excess which equate to the social status of those eating these items. While ham may not have been expensive, the peaches and the crayfish indicate that the participants in the scene had enough money to be able to afford such expensive items. The excess of the foodstuff in the dining scene reinforces the luxuriousness of its participants in addition to the excessive nature of the entire event.

The depiction of these food items should not necessarily be viewed in ways similar to traditions of vanitas paintings that emphasize the fleeting nature of morality. While Le déjeuner de jambon does display wealth and pleasure, there is no sense of futility. The figures are ephemeral and the moment fleeting, but there are no hints at death. The associations of the foodstuff should rather be seen as a means of amusement and a joie de vivre brashness. A type of tongue-in-cheek humor permeates this painting as well as others by Lancret.

Even though Le déjeuner de jambon depicts only one of the many aspects of the previously discussed characteristics of the hunt luncheon genre, dogs, it is typically

${ }^{352}$ Malaguzzi, Food and feasting in art, 145. 
discussed as such by scholars. Rather than its iconography, it is the circumstances surrounding its commissioning that allow the painting's inclusion in the category of hunt luncheons. Le déjeuner de jambon is the first hunt luncheon by Lancret that depicts a true stylistic break with Watteau in addition to being a royal commission. It was commissioned in 1735 for Louis XV's newly-conceived private dining rooms at Versailles. ${ }^{353}$ This new salle à manger was a place where the king could entertain his companions after their hunting excursions. The king invited both male and female members of the court to this space, which was designed to seat about twenty guests. ${ }^{354}$ In addition to the painting's original context, it was framed by wooden carvings depicting motifs of the hunt which further its connection to the hunt. ${ }^{355}$

The salle à manger was part of a larger renovation project that included the king's petits cabinets, the entirety of which was decorated with scenes of hunting and animals, among other genre scenes. ${ }^{356}$ Another commission from Lancret, The Tiger Hunt, was part of a series of exotic hunts displayed in the petite galerie. The Bâtiments du Roi also commissioned similar paintings from other artists such as Boucher, Jean-Baptiste Pater (1695-1736), Carle van Loo (1705-1765), Charles Parrocel (1688-1752), and de Troy. Given the all-encompassing theme of the hunt for the king's private space, it is therefore easy to ascertain why Le déjeuner de jambon is included in the genre of the hunt luncheon paintings.

\footnotetext{
${ }^{353}$ For the development of the dining room as a fixture within eighteenth-century architecture, the tradition of decorating it with hunting scenes, and a discussion of how Lancret's work and its pendant fit into the new space see Williams, "Dining and Revelry in French Rococo Art."

${ }^{354}$ Marie, Versailles au temps de Louis XV, 235-236; Wheaton, Savoring the Past, 156.

${ }^{355}$ Holmes, Nicolas Lancret, 1690-1743, 78.

${ }^{356}$ Holmes, Nicolas Lancret, 1690-1743, 57.
} 
Another painting commissioned for the salle à manger, Jean-François de Troy's Le déjeuner d'huitres (figure 112), is generally considered a pendant to Lancret's work. De Troy's painting is compositionally similar to Lancret's as both depict dining and are relatively the same size. Lancret's painting, however, is far more informal and depicts an outdoor setting as opposed to the more formal indoor scene by de Troy. Despite the variances in locale and formality, both paintings reflect a luxurious lifestyle only available to the wealthiest aristocracy. Like the crayfish depicted in Lancret's painting, the subject of de Troy's painting, the oysters, imply luxury and excess, as oysters were overfished during the middle part of the century and presumably only the wealthiest would have been able to obtain them. ${ }^{357}$ In this instance, they also allude to sensual pleasures enjoyed by the men depicted. Oysters have long-standing connotations of being an aphrodisiac and enhancing male virility. Holmes has suggested that these two paintings depict the "post-hunt revelry that took place in the room, with one painting focusing on city roistering, the other on country." ${ }^{, 358}$ It was apparently this type of sensual pleasure and lifestyle which amused the king and that which he wanted to be living inside his new salle à manger.

At some point, Lancret made a copy of the painting commissioned by the Bâtiments $d u$ Roi for the king's salle à manger. However, it remains unclear who this replica was painted for. The painting bears the same title as the royal commission, Le déjeuner de jambon (figure 113), and is currently in the collection of The Museum of Fine Arts, Boston. Art historians have debated its provenance, but no one theory has been accepted.

\footnotetext{
${ }^{357}$ Robert Neild, The English, the French, and the Oyster (London: Quiller Press Ltd., 1995), 78.

${ }^{358}$ Holmes, Nicolas Lancret, 1690-1743, 57.
} 
Mary Tavener Holmes contends that the painting was commissioned by Ange-Laurent de La Live de Jully (1725-1779), a leading art collector. It has been documented as part of his collection until 1766. ${ }^{359}$ However, Frances Gage notes that La Live de Jully would only have been ten years old if the painting was commissioned in 1735 , the accepted date of the original work, though the scholar does not name an alternative patron for the work. ${ }^{360}$

Minor details differentiate the second version of Le déjeuner de jambon from the royal one; most noticeably that the table has been modified from a round one to a square. The statue of the satyr and the feline has been transformed into a simple urn, the female companion is making the sign of a cuckold above the head of the man she stands behind, and the design of the porcelain on the table has been changed. The woman's hand gesture furthers the sinful, erotic nature of the painting which may be more appropriate in this version of the painting than the royal commission from the king. A cuckold is a man who, either knowingly or unknowingly, is being cheated on by his wife or mistress. While the king did have official mistresses, his relationship with them had priority over their relationships with their husbands, thus, the king would not have permitted himself to be cuckolded, making this hand gesture improper for his version of the painting.

In addition to the woman's hand gesture, the overturned chair is missing from the foreground, one dog has been added, the coloring of another dog and the cat has been altered, and a copper basin is missing. Slight modifications also appear in the servants to

\footnotetext{
${ }^{359}$ Holmes, Nicolas Lancret, 1690-1743, 78.

${ }^{360}$ Bailey, The Age of Watteau, Chardin, and Fragonard, 146; "Luncheon Party in a Park" The Boston Museum of Fine Arts, http://www.mfa.org/collections/object/luncheon-party-in-a-park-33938; the Museum dates the work as "about 1735."
} 
the left, the coloring of the party's clothing, and gestures. The ham is still the central feature of the luncheon scene, and the peaches are still depicted on a platter held by a servant. However, the few scattered crayfish shells are missing, but the servant holding a platter of them remains.

The Boston painting also appears to lack the same clarity of detail in the rendering of faces and particularly in the servants and the man who stands behind the central figure of the would-be Bacchus. With the exclusion of the satyr and feline statue, the association of this central figure as a modern-day Bacchus is diminished greatly, and only a viewer who was aware of the original painting may have realized this inference. The painting does not appear to be a sketch since it is rendered with much of the same clarity of detail as the original and does not resemble the other known preliminary oil sketches completed by the artist. Regardless of the details its commissioning, the second surrounding version of Le déjeuner de jambon is a testament to the popularity of the original painting, its subject matter, and Lancret's ability to capitalize on a popular commission.

\section{Le déjeuner dans le foret (1738)}

Another hunt luncheon painted about the same time as the royal commission of Le déjeuner de jambon is Le déjeuner dans le foret (figure 114). Unlike Le déjeuner de jambon, Le déjeuner dans le foret contains all of the necessary accoutrement of the hunt luncheon genre and is clearly meant to represent a halte during a hunting excursion. While Le déjeuner dans le foret was not a royal commission, it did find its way into a royal collection. 
In addition to his royal commissions for Louis XV, Lancret's paintings were collected by King Frederick of Prussia. King Frederick is said to have owned twenty-six paintings by Lancret, including Le déjeuner dans la foret. ${ }^{361}$ However, little is known about the painting before it entered the collection of Frederick the Great.

Le déjeuner dans la foret survives in two iterations: the presumed oil sketch at the Detroit Institute of Arts (figure 115) and the final painting, bought by Frederick, now in the collection at Sanssouci. Except for visible architecture or an architectural element, such as the fountain in Le repas au retour de chasse or the wall and garden trellis in Le déjeuner de jambon, all of the elements of a hunt luncheon painting appear in these works. Both the sketch and the final version depict women wearing hunting costumes, though as with Le repas au retour de chasse the women depicted did not participate in the hunt; this can be deduced from the presence of the carriage behind the party that brought them to the scene. Additionally, in the final version of the painting, the standing woman in brown, tricorn in hand, does not wear boots but the same pointed mules as the women in Le repas.

The men and women of the party are enjoying bread and wine while a servant to the right of the painting stands holding a platter that holds a pâté en croute similar to the one seen in Le repas au retour de chasse. The mule behind him is loaded with baskets which hold more bread and wine, and another servant inspects a bottle of wine to the right of the mule. The meal in Le déjeuner dans la foret is very similar to the one depicted in Le repas au retour de chasse; the only thing missing is the tray of peaches and the meat pie.

\footnotetext{
${ }^{361}$ Holmes, Nicolas Lancret, 1690-1743, 76; Conisbee, French Painting of the Fifteenth through Eighteenth Century (Princeton, N.J.: Princeton University Press, 2009), 291.
} 
In Le déjeuner dans la foret Lancret utilized an almost identical composition as that of Le repas au retour de chasse (figure 46). All three paintings: both the sketch and the final version of Le déjeuner dans la foret and Le repas au retour de chasse contain practically the same figural grouping of the luncheon participants seated around the white tablecloth spread on the ground. The central woman in yellow in Le repas is depicted in the same position as the woman in brown who appears to feed the dog in the Detroit and Sanssouci paintings. The woman in the pink and silvery blue hunting costume seated at the right of Le repas also appears in the sketch for Le déjeuner wearing blue and cream and in the final version in a slightly altered pose wearing pink. The lounging man at the left in Le repas takes the place of the kneeling servant in the Detroit work and the kneeling companion in the Sanssouci work. The central standing man in Le repas appears in the Detroit work with slight differences between the two figures, mainly the hand in which he holds his gun and his positioning in relation to the other figures; his gestures are similar but have been more exaggerated in the Louvre painting. Presumably the same man is depicted in the Sanssouci painting at the center since this figure also holds a gun, but he has been altered to interact with the hunting dog. Most noticeably, the relationship of the size of the figures to the landscape is more similar between Le repas and the presumed sketch for Le déjeuner; however, this is probably due to the trimming of the Le repas and the instance of Le déjeuner's status as a sketch. Both works depict the figures as larger in relation to the landscape with the participants taking up more space within the paintings. In contrast to the final version of Le déjeuner in which the figures appear smaller in comparison is more in keeping with Watteau's established proportions and those used by Lancret at this early point in his career. The reason for the difference in the 
figural relationship between the two versions of Le déjeuner may be as simple as the artist's focusing on the composition of the sketch before the completion of the final version. Additionally, all three paintings have compositional affinities to Lancret's earlier La fin de chasse.

With scholars' redating of Le repas au retour de chasse, Holmes has also suggested that the date of the completed Le déjeuner should be placed around 1739 due to a description of a painting by Lancret in the 1739 Salon. ${ }^{362}$ This Salon mention is rather vague and simply states, "A painting 3 feet by 4 wide, representing a lunch and rest of [a] hunt[ing] [party]." ${ }^{363}$ While this was not the only painting Lancret showed at the Salon, none of his other paintings were hung on the same wall, indicating that the work did not have a pendant. Since the Salon of 1739 was the first to do away with the previous numbering scheme and simply mention the works with regard to where they were hung, it would seem that the painting mentioned did not have a pendant. Further, this redating of Le déjeuner seems to follow the progression of Lancret's stylistic developments. The figures are larger and better integrated into their surrounding landscape than Lancret's earlier work, Le repas italien (figure 64) also in the collection of Frederick the Great which is discussed in the following chapter. Though both Le déjeuner and Le repas italien display the artist's mature figural style, the figures vary in relative scale to their settings.

\footnotetext{
362 Holmes, "Katalog: Nicolas Lancret," 590.

${ }^{363}$ L'Academie Royale, Explication des Peintres, Scultpures, et Autres Ouvrages de Messieurs de L'Academy Royale (1739), 17, http://gallica.bnf.fr/ark:/12148/btv1b84427785; “Un Tableau de 3. Pieds sur 4. de large, représentant un Déjeûné et repose de Chasse."
} 


\section{Le repas de chasse $(1735 / 40)$}

In addition to Le déjeuner dans le foret, Frederick the Great owned another hunt luncheon by Lancret. Le repas de chasse (figure 116) is the artist's last depiction of the subject and is indicative of his most mature artistic production. The figures are slightly larger than those in Le déjeuner dans le foret with the surrounding landscape also displaying a more mature rendering that aligns with the later part of the artist's career. As such, the date of 1740 seems to be the correct dating of this painting as opposed to the earlier 1735 date sometimes given. Holmes notes the date as about 1738 in the Französische Gemalde entry on the painting. ${ }^{364}$

Le repas de chasse is now in the collection of the National Gallery in Washington D.C. but little is known of the painting before its appearance in Frederick's collection in 1793. ${ }^{365}$ This painting contains all the characteristics and most of the required accoutrement to be considered as a hunt luncheon; as with Le repas au retour de chasse, the only objects it lacks are guns and a hunting horn, which may not have been needed depending on the type of hunt depicted. Similar to Le déjeuner de jambon, the food items Lancret chose to depict are commonly eaten during a hunt luncheon, though in this instance the scene is not necessarily a meal, but rather a snack whose elegance and luxury matches the women who have ridden out to join the hunting party.

The male servant at the left holds a bowl of peaches, while the woman in the yellow dress reaches for what Holmes had earlier called "a frothy confection," but now refers to as a sweet foam. ${ }^{366}$ Both the peaches and the sweet confection carry

\footnotetext{
${ }^{364}$ Holmes, "Katalog: Nicolas Lancret," 683.

${ }^{365}$ Holmes, "Katalog: Nicolas Lancret," 683.

${ }^{366}$ Holmes, Nicolas Lancret, 1690-1743, 76 ; Holmes, "Katalog: Nicolas Lancret," 589 ; „ein Schaumkonfekt"،
} 
connotations of the wealth and social status of the people consuming them in the painting. As previously stated, peaches were seen as a luxury item and could be forced to produce outside of their normal growing season. It is obvious that peaches were a luxury that the participants of this scene could afford potentially year-round. In this instance, however, the peaches relate more to the social status of the participants than the sinful or lustful nature of the scene, as they did with Lancret's commission for the king. Moreover, Lancret seems to have taken into account how the peaches would have arrived at the scene with the inclusion of a horse loaded with baskets, the proper method of transportation for this delicate fruit. A similar basket is depicted in Le déjeuner dans le foret; however, there is no indication of peaches being served. Additionally, though not discernible in Lancret's painting, peaches should be wrapped in vine leaves and laid blossom end up on a bed of moss before being placed in a basket when being transported..$^{367}$

The "frothy confection," or sweet foam, presumably consisted of whipped cream, sugar, and a flavoring. Sweet foams, typically referred to as niege, or snow, were made by whipping the cream, sugar, and flavor, scraping the foam off the top, letting it drain, and chilling it; these desserts sometimes included the addition of meringue to help with their stabilization. ${ }^{368}$ Alternatively, this confection could also be identified as sorbet, an ice, or an ice cream which were also introduced to France in the seventeenth century. ${ }^{369}$ Made with the same ingredients as the niege, it is the processes of production that creates

\footnotetext{
${ }^{367}$ Pinkard, A Revolution in Taste: the rise of French Cuisine, 76-77.

368 Jeri Quinzio, Of Sugar and Snow: A History of Ice Cream Making (Berkeley, CA: University of California Press, 2009), 8.

${ }^{369}$ Jean-Francois Revel, Culture and Cuisine: A Journey through the History of Food, trans. Helen R. Lane (New York: Da Capo Press, 1982), 165.
} 
the different confections. Ices, or eaux glacées, were not whipped and drained like the niege, but frozen gradually over a number of hours. Since the ice and salt required to make such items were expensive, and scarce in the case of ice, only the wealthiest person would have been able to obtain them, along with a chef who knew how to make the treats. ${ }^{370}$ Such concoctions could be transported using a cave, a small oblong icebox, made of metal and lined with iron or zinc. ${ }^{371}$ Therefore, the appearance of this food item in Lancret's painting would not have been completely unrealistic, as it could have been brought to the scene by a servant from the house depicted in the far-right background. Indeed, it appears as though an icebox, such as the one described above, is included in the painting next to the right leg of the kneeling man pouring water from a waterskin into a glass carafe. Furthermore, the serving dish is similar to one depicted in Massialot's illustration for a dessert service. It resembles the small bowls that ring a pyramid which are described as ices. ${ }^{372}$ Lancret's dish has two handles on either side of the dish similar to a trembleuse used for hot chocolate. Since no table is present in this image, the two handles would allow for the woman to better hold the cup.

Recent scholarship has linked Le repas de chasse with that of another of Lancret's paintings entitled Fête galante entre une tente et une rivière (figure 117), suggesting that the two were pendants. ${ }^{373}$ Holmes offers a comparison to Le repas au retour de la chasse and Fête galante entre une tente et une rivière as artistic precedents for this pairing. It may be that they were paired while in the collection of Frederick, though were not originally conceived as pendants by the artist. Holmes notes that, similar to Le repas de

\footnotetext{
${ }^{370}$ Quinzio, Of Sugar and Snow, 27.

${ }^{371}$ Quinzio, Of Sugar and Snow, 38.

372 Elizabeth David, Harvest of the Cold Months (New York: Penguin Books, 1994), 101.

${ }^{373}$ Vogtherr and Holmes, De Watteau À Fragonard, 78.
} 
chasse, Fête galante entre une tente et une rivière appeared in the collection of Frederick the Great in $1793 .{ }^{374}$ The paintings do have some affinities, such as the similar poses of the man in blue and woman in yellow in Le repas and the two dancing figures in Fête galante entre une tente et une rivière. Still, the paintings are very different in attitude; Fête galante entre une tente et une rivière seems more relaxed and the figures less selfpossessed than Le repas and its emphasis on social class.

As previously discussed, Lancret may not have been the first artist to depict the hunt luncheon; however, his painting of the subject matter does differ from those of Joseph Parrocel, Watteau, or even Lemoyne. In Parrocel's The Return from the Hunt, Watteau's Rendezvous de chasse, and Lemoyne's Le déjeuner de chasse, all the artists are more concerned with the amorous nature, theatrical or exotic costumes, and all have little to do with the act of hunting or dining. As Holmes rightfully states, "in none of these examples we can find a similar emphasis on the elements of actual hunts, contemporary clothing, and details as Lancret." ${ }^{375}$

However, as is evident in Chapter One, Lancret took various elements of Watteau's fêtes galantes and combined them with the aristocratic pastime of the hunt to create this new hunt luncheon genre. Lancret was able to take advantage of the popularity of Watteau's paintings after the elder artist's untimely death and continued to produce paintings that captivated a similar audience. However, Lancret did develop his own highly personal figural style, and the subject of the hunt luncheon is not one readily found in Watteau's oeuvre. Furthermore, Lancret utilized the iconography of the foodstuff he

\footnotetext{
${ }^{374}$ Vogtherr and Holmes, De Watteau À Fragonard, les fêtes galantes, 196.

${ }^{375}$ Holmes, "Katalog: Nicolas Lancret," 591; „In keinem der genannten Beispiele finden wir eine ähnliche Betonung der Elemente tatsächlicher Jagden, zeitgenössischer Kleidung und Details wie bei Lancret“"
} 
included in his paintings to help further the story and atmosphere of his paintings in a way that Watteau had not.

The food items that Lancret depicted and are integral to the genre of hunt luncheon paintings. Not only do they help to characterize and define paintings of the hunt luncheon, they are also an essential detail in Lancret's other dining scenes, many of which have roots in Northern genre scenes. Much like the hunt luncheons, the paintings of the seasons, times of year, and kitchen scenes painted by Lancret are indebted to Watteau. However, more importantly, Lancret looked past Watteau to the Northern painters by whom the elder artist was influenced. In doing so, Lancret was able to integrate noble identities, pastimes, and the iconography of food items with artistic modes of genre painting to create the wholly contemporary genre scene of the hunt luncheon. 


\section{Conclusion}

As Pierre Rosenberg's quote that opens Chapter One indicates, even in the last quarter of the twentieth century Nicolas Lancet's standing as a mere follower of Watteau was perpetuated by leading eighteenth-century scholars. While Gersaint and Mariette preferred works by their friend Watteau over Lancret's in the eighteenth century, Lancret was a well-liked by collectors and connoisseurs during his own lifetime. The artist's careless oversight by modern scholars may be a continuance of the art historiography disseminated in the early nineteenth century by the Goncourt brothers, Edmond and Jules. Their appraisal of Lancret was only as a "servile continuator" of Watteau's artistic developments. ${ }^{376}$

The Goncourt brothers said the same of Jean-Baptiste Pater. During the eighteenth and nineteenth century Lancret and Pater were often discussed together by critics as the two main followers of Watteau. Pater was only five years younger than Lancret but was admitted to the Académie as a painter of fêtes galantes nine years after Lancret. Unlike Lancret, Pater did study under Watteau during two different periods of his artistic training; he is the only known artist to have worked directly with Watteau. ${ }^{377}$ Perhaps due to this association, Lancret still acquired the title of follower, pupil, or emulator of Watteau. For example, Auguste Jal wrote that Lancret, "Watteau's pupil, who marched almost equally to his master, eclipsed Pater, his graceful and witty emulator." 378 Jal

\footnotetext{
${ }^{376}$ Edmond and Jules Goncourt, L'art au XVIIIe siècle : séries I, II, III (Paris : G. Charpentier, Éditeur, 1881), 80 ; « des ses continuateurs serviles »

377 Christoph Martin Vogtherr, "Moving on from Watteau: Jean-Baptiste Pater and the Transformation of the Fête Galante" in French Art of the Eighteenth Century: The Michael L. Rosenberg Lecture Series at the Dallas Museum of Art edited by Heather MacDonald (New Haven: Yale University Press, 2016), 85.

378 Auguste Jal, Dictionnaire Critique de Biographie et d'Histoire (Paris: Henri Plon, 1872), 734; « ...élève de Watteau, qui marcha à peu près l'egal de son maître, éclipsa Pater, son gracieux et spirituel émule... »; It is unclear which of the two artists Jal is calling graceful and witty in this sentence but seeing as how the
} 
acknowledges Lancret's debt to Watteau, and his artistic mastery in relation to Pater, yet he still deemed him Watteau's pupil.

Not all modern scholars have been so dismissive of Lancret. Michael Levey noted that "Lancret is the one painter who stands out among the Watteauesque artists, and he is also the one who has suffered most perhaps from juxtaposition to Watteau." ${ }^{379}$ At the same time, however, Levey criticizes Lancret's figures for their lack of individuality and the narrow range of his works while he praises competence as a draughtsman. ${ }^{380}$ While waffling in his praise and criticism of Lancret, Levey is staunch in his condemnation of Pater. The scholar remarks that Pater's artistry was "devoted and timid, and the more irritating the more closely he pastished his master" and his fêtes galantes are "insipid."381

Levey's use of the term pastiche is due in part to Pater's continued borrowing of figural compositions from paintings by Watteau in his own works, something Lancret did early in his career, but he moved away from imitation in his later paintings. Both artists used strong diagonals to join the landscape with the background of sky and clouds, another method adopted from Watteau. However, Pater developed compositions that reflected the sinuous lines of rococo scrolls, while Lancret's spatial coherence was more linear. ${ }^{382}$ Nevertheless, Pater has fared worse than Lancret as an emulator of Watteau, receiving little modern critical attention. ${ }^{383}$ He continued to paint in the style he learned from Watteau, making only slight variations to the formulaic fêtes galantes he completed.

\footnotetext{
author writes that Lancret has eclipsed Pater, Lancret would then be even more witty and graceful than the younger artist.

${ }^{379}$ Michael Levey, Painting and Sculpture in France: 1700-1789 (New Haven: Yale University Press, 1993), 43.

${ }^{380}$ Levey, Painting and Sculpture in France, 43-44.

${ }^{381}$ Levey, Painting and Sculpture in France, 44.

${ }^{382}$ Vogtherr, "Moving on from Watteau," 87.

383 See Vogtherr, "Moving on from Watteau," 81.
} 
In a recently published essay, Christoph Martin Vogtherr credits Pater with having made subtle changes to the genre; most of the changes he notes also appear in paintings by Lancret: the brightened color palette, three-dimensionality and added movement of the figures, greater narrative potential, and references to Arcadian ideals. ${ }^{384}$ After Watteau's untimely death, it seems only reasonable that Pater would have been influenced by the painter who best assimilated everything Watteau's fêtes galantes had offered and would have used these aspects to create a new type of genre.

Lancret's creation of the hunt luncheon paintings are a reflection of the sociocultural attitudes of his patrons and society. He captured the light-hearted, leisure pastimes of the aristocracy in the vibrant and colorful palette of the Rococo period. More than this, however, he also created and popularized a new genre of painting. While he has long been unfavorable seen as only a follower of Watteau, upon closer examination it becomes clear that this was not the case. Lancret's inventive combination of historical and contemporary traditions of genre painting captured the societal values of the eighteenth century. While they may not entirely depict the real lived experiences of the aristocracy and wealthy financiers who collected his paintings, they are idealized representations of how they wanted to be seen and portrayed.

Moving past the influence of Watteau and his creation of the fête galante, this dissertation examines an artist who followed in Watteau's footsteps but continued to transform and reinvent genre paintings in an analogous manner. Despite Lancret's early emulation of the elder artist, he developed his own figural style that is easily distinguishable from Watteau's. While he may have been reliant on the older artist for the

${ }^{384}$ Vogtherr, "Moving on from Watteau," 82, 86, 91. 
subjects of his paintings, Lancret was still able to manipulate and transform the subjects in a manner not previously seen. This ingenuity culminated in Lancret's creation of the hunt luncheon genre, which, while still reliant upon Watteau's own creation of the fête galante, took Watteau's developments and combined them with other traditions to make a new type of image. These hunt luncheon paintings were extraordinarily modern in the facets of aristocratic material consumption and leisure time activities. Like Watteau, Lancret found inspiration in the various genre series and scenes typically found in Dutch and Flemish paintings. In this aspect, Lancret was looking past Watteau to the paintings that had inspired the elder artist. Lancret returned to the original sources and combined his own cultural influences and pastimes with traditions of older genre paintings of the North.

While scholars have acknowledged Lancret as the generator of this new genre of the hunt luncheon paintings, none have investigated the multitude of artistic influences he used to conceptualize this genre. The influence of Watteau on Lancret's oeuvre goes without saying; however, the influence of fashion prints, Northern genre paintings, and popular leisure and social pastimes had not received satisfactory attention, nor had scholars considered the various social factors and customs of the hunt and the popularization of new foodstuff. Lancret acknowledged the numerous ways the aristocracy utilized arts and leisure as a means to set themselves apart from the everencroaching bourgeoisie. Furthermore, while artists such as Francois Boucher are discussed as businessmen who understood and capitalized on the market conditions of the eighteenth century, Lancret had never been investigated in these terms until this investigation. It has been recognized by scholars that he must have benefited from some 
aspects of the art market during his career since he produced numerous prints after his paintings; however, it appears that Lancret was more adept at marketing himself and exploiting Watteau's success than just making prints.

Watteau's paintings often displayed the social pastimes of the aristocracy, focusing mainly on promenading and sociability of the figures in park-like or garden settings. Many scholars have noted the way in which the artist's subjects were ambiguous; the actions of the figures are often unclear. Furthermore, Watteau depicted his figures in outdated fashions or theatrical costumes from the previous century. Watteau's paintings are of timeless fantasies, and the figures who inhabit them often have a whimsical air of mystery. Boucher's production was much more varied than Watteau's and includes portraits, religious subjects, mythologies, and scenes of country life. It is the mythological paintings for which Boucher is perhaps best known. While most of Boucher's rustic genre paintings are fully imagined fanciful depictions of bucolic ideals, Lancret's include glimpses of actual social pastimes and contemporary objects. As Mary Vidal has noted, Lancret instead depicts his figures "in the here-and-now of worldly luxury" in a way that Watteau and Boucher did not. ${ }^{385}$ In this way, Lancret's paintings depict contemporary aristocratic social values sometimes lacking in the paintings of his contemporaries. In this aspect, Lancret is only rivaled by his contemporary Jean-François de Troy. However, even de Troy's tableaux de mode seem more focused on the fashions and decorative objects than the underlying social conventions, practices, and ideals of aristocratic leisure.

\footnotetext{
385 Mary Vidal, Watteau's Painted Conversations (New Haven: Yale University Press, 1992), 73.
} 
Lancret's choice of subject reflected the priorities of his patrons. Louis XIV was recently dead, and his stranglehold on the aristocracy died with him. The Regent lived a more libertine lifestyle that dominated court until Louis XV reached the age of majority. Louis XV preferred a more private life than his great-grandfather and was not paranoid of the aristocracy's scheming as Louis XIV had been after The Fronde. With the aristocracy subdued and no longer under the harsh control of Louis XIV, greater freedoms were enjoyed away from the court. This resulted in new building and decorating campaigns that served as spaces for these new-found freedoms. In turn, the paintings commissioned for these châteaux and hôtels depicted the very leisure pastimes the aristocracy were busy pursing away from the watchful eye of the king. The new social issue to contend with was the rising middle class who were becoming increasingly more wealthy and able to buy courtly positions that had previously been passed on through heredity. Leisure pastimes and depictions of such pastimes were a way for the aristocracy to continue to define and distinguish themselves from the haute bourgeoisie through the carefully controlled displays of honnêteté and politesse. These activities replaced the lofty themes of history and mythology in painting, thus, Lancret's genre paintings of hunting, dancing, dining, and consuming hot beverages help to further these social distinctions between the classes.

While Watteau's fêtes galantes were known for their ambiguous subjects, the politesse and honnêteté of their participants was still essential. Similarly, these traits are as vital in Lancret's paintings, even when he is toying with them as he does in $L e$ déjeuner de Jambon and Les Heures du Jour: Le Matin. Yet, Lancret manages to imbue his paintings with the pastoral tradition in ways different from Watteau's paintings which 
foreshadowed Boucher's works a few decades later. Lancret is therefore not a mere follower but a key figure in the transference and continuation of major themes and subjects in eighteenth-century French painting.

The artistic developments of the early eighteenth century are not based on a few key figures such as Watteau, Boucher, and Fragonard, but should be seen as a dialogue between innumerable artists, past and present, living and working in Paris and beyond. Watteau and Lancret were not working in isolation from other artists and French society but as part of a large community. The collaborative nature of assimilation, adaptation, and reinterpretation was an ongoing process. Much like Georges Braque is left out of the discussion of Cubism for the layman but well-known to scholars, Lancret is not a name known to scholars outside of the field of the eighteenth century.

With the reevaluation of artists such as Lancret, the field of eighteenth-century scholarship has the potential to expand exponentially. Many artists such as Lancret were successful and popular during their own time only to be devalued during the late nineteenth and early twentieth century as result of the shift away from a monarchical to a more democratic form of government and the transition from the decadent Rococo period to the politically charged Neoclassical style. This reevaluation of lesser-known eighteenth century artists will only serve to expand art historical understandings about artistic processes, social and political influences on art-making of the period, and the art market. This investigation is just one small instance of the work still to be done on artists during the eighteenth century who have not yet received due attention. 


\section{Bibliography}

Ackland Art Museum. Catalogue Work Sheet: Accession Number: 72.22.1, Nicolas Lancret. Print, unpublished.

Ackland Art Museum, University of North Carolina at Chapel Hill. "The Feast in Film, Philosophy, and Fiction: A Virtual Gallery of Images from the Ackland Art Museum." Last modified Fall 2010. http://feast.web.unc.edu/lancret/.

Ackroyd, Paul, Ashok Roy, and Humphrey Wine.. "Nicolas Lancret's The Four Times of Day." National Gallery Technical Bulletin, Volume 25 (2004): 48-61.

Androsov, Sergei. "Two Pastimes of Catherine II: Collecting and Building." In Catherine the Great: an enlightened Empress, by the National Museums Scotland, 45-61. Edinburgh: NMS Enterprises, 2012.

Aradas, Michael S. The Etiquette of Social Violence: Hunting and Nobility in Early Modern France. Order No. 3043698, Purdue University, 2001. http://proxy.mul.missouri.edu/login?url=https://search-proquestcom.proxy.mul.missouri.edu/docview/304724069? accountid=14576.

Atwater, Vivian Lee. "A catalogue and analysis of eighteenth-century French prints after Netherlandish Baroque paintings." Order No. 8826363, University of Washington, 1988. http://proxy.mul.missouri.edu/login?url=https://searchproquest-com.proxy.mul.missouri.edu/docview/303592064 accountid $=14576$.

Atwater, Vivian Lee. "Les graveurs et la vogue néerlandaise dans le Paris du xviiie siècle. II. Le Bas, Teniers et l'idealisation de la vie paysanne." Nouvelles de l'estampe, 142-3 (October 1995): 3 -12.

Atwater, Vivian Lee.. "The Netherlandish vogue and print culture in Paris, 1730-1750." Simiolus: Netherlands Quarterly for the History of Art Vol. 34, No. 3/4 (2009/2010): 239-250.

Bailey, Colin B.""Details that serruptitiously explain": Boucher and a Genre Painter." In Rethinking Boucher, edited by Melissa Hyde and Mark Ledbury, 39-60. Los Angeles: Getty Publications, 2009.

-. The Age of Watteau, Chardin, and Fragonard: masterpieces of French genre painting. New Haven: Yale University Press, 2003.

Ballot de Sovot, Silvain. "Éloge de Lancret, peintre de Roi." In Éloge de Lancret, peintre de Roi, by J.J. Guiffrey, 17-33. Paris: Rapilly, c. 1874. https://books.google.com/books?id=OvoGAAAAQAAJ\&pg=PA67\&dq=sovot\&e $\mathrm{i}=\mathrm{NCpSW} 4 \mathrm{rZIJW} 8-\mathrm{wHL}-\mathrm{qaADw} \& \mathrm{~cd}=3 \# \mathrm{v}=$ onepage $\& \mathrm{q} \& \mathrm{f}=$ false .

Banks, Oliver T. Watteau and the north : studies in the Dutch and Flemish baroque influence on French rococo painting. New York: Garland Pub, 1977. 
Barrat, Jacques and Arnaud Fréminet. La vènerie française: un patrimoine d'avenir. Paris: Bibliothèque des introuvables, 2007.

Barter, Judith. Art and Appetite: American painting, culture, and cuisine . Chicago: Art Instituite of Chicago, 2013.

Barthes, Roland. "Toward a Psychosociology of Contemporary Food Consumption." In Food Drink in History, edited by Robert Forster and Orest Ranum. Translated by Elborg Forster and Patricia M. Ranum, 166-173. Baltimore: The Johns Hopkins University Press, 1979.

Batz, Georges. "French Cusines." Art Quarterly, Vol. 9, No. 1 (1946):307-313.

Baxter, Amy Denise. Fashions of Sociability in Jean-François de Troy's tableaux de mode, 1725-1738. PhD Dissertation, Santa Barbara: University of California, 2003.

Bendiner, Kenneth. Food in Painting. London: Reaktion Books, 2004.

Bernier, Oliver. Louis the Beloved: The Life of Louis XV. New York: Doubleday \& Company, Inc, 1984.

Bibliothèque nationale de France. Palais Royal: à table des Rois. Paris: Bibliothèque nationale de France, 2015.

Biziere, Jean Maurice. "Hot Beverages and the Enterprising Spirit in Eighteenth-Century Europe." The Journal of Psychohistory Vol. 7, No. 2, (Fall 1979.): 135-145.

Blégny, Nicolas de. Le Bon Usage de thé, du caffé et du chocolat pour la préservation et pour la guérison des maladies. Lyon: Chez Thomas Amaulry, 1687. Bibliothèque nationale de France, département Sciences et techniques, S-14830.

https://gallica.bnf.fr/ark:/12148/bpt6k1055037.

Bocher, Emmanuel. Les Gravures Francaise du XVIIIe siècle ou Catalogue Raissonné des estampes, eaux-fortes, pièces en couleur, au bistre et au lavis, de 1700 a 1800. Paris: A La Librarie des Bibliophiles, 1877. Bibliothèque nationale de France, département Sciences et techniques, 4-V-16. https://gallica.bnf.fr/ark:/12148/bpt6k5566937v

Bonnet, Jean-Claude. "The Culinary System of the Encyclodédie." In Food and Drink in History, edited by Robert Forster and Orest Ranum. Translated by Elborg Forster and Patricia M. Ranum, 139-165. Baltimore: The Johns Hopkins University Press, 1979.

Brown, Peter B. and Ivan Day. Pleasures of the Table: Ritual and Display in the European Dining Room 1600-1900. York: York Civic Trust, 1997.

Bruegel, Martin, Jean-Michel Chevet, and Sébastian Lecocq. "Animal Protein and Rational Choice: Diet in the Eighteenth Century." Jounal of Interdisciplinary History, XLIV:4 (Spring 2014): 427-452. 
Burnand, Tony. Connaissance et pratique de la chasse. Paris: Éditions Denoel, 1967.

—. Dictionnaire de la chasse. Paris: Librairie Larousse, 1970.

Cailleux, Jean. "Invalids, Hunstmen, and Squires." The Burlington Magazine, Vol. 106, No 731 (Feb. 1964): i-iii.

Cassidy-Geiger, Maureen, ed. Fragile diplomacy: Meissen porcelain for European courts ca. 1710-63. New York: Yale University Press, 2007.

Chabrol, Brigitte. Encyclopédie de la vènerie française. Paris: O. Perrin, 1961.

Château de Condé - Demeure des Princes. Visitors Guide. Print, unpublished, n.d.

Château de Condé. "Château de Condé, Le Château des Princes de Condé, BourbonSoisson, et de Savoie." Accessed February 4, 2018. https://www.chateaudeconde.fr/.

Chevallier, Jim. "The Queen's Coffee and Casanova's Chocolate: The Early Modern Breakfast in France." In Consuming Culture in the Long Nineteenth Century: Narratives of Consumption, 1700-1900, edited by Tamara S. Wagner and Narin Hassan, 191-208. Lexington Books, 2007.

Childs, Adrienne L. "Sugar Boxes and Blackamoors: Ornamental Blackness in Early Meissen Procelain." In The cultural aesthetics of eighteenth-century porcelain, edited by Alden Cavanaugh and Michael Yonan, 159-177. Farnham, Surrey, England ; Burlington, VT: Ashgate, 2010.

Christie's Auction House. "Nicolas Lancret (Paris 1690-1743), Autumn, 18th Century, Paintings, April 27, 2017." Accessed 2018. https://www.christies.com/lotfinder/Lot/nicolas-lancret-paris-1690-1743-autumn6068912-details.aspx?lid=1\&sc_lang=en.

Clarence-Smith, Williams Gervase. Cocoa and Chocolate, 1765-1914. London: Routledge, 2000.

Coe, Sophie D. and Michael D. Coe. The True History of Chocolate. New York: Thames and Hudson, 1996.

Cohen, Sarah R. "Masquerade as Mode in the French Fashion Print." In The Clothes that Wear Us: Essays on Dressing and Transgressing in Eigheenth-Century Culture, edited by Jessica Munns and Penny Richards, 174-207. Newark: University of Delaware Press, 1999.

Conisbee, Philip. French Genre Painting in the Eighteenth Century. New Haven: Yale University Press, 2007.

-. French Paintings of the Fifteenth through the Eighteenth Century. Princeton, N.J.: Princeton University Press, 2009. 
—. "The Eighteenth Century: Watteau to Valenciennes." In Claude to Corot: The Development of Landscape Painting in France, edited by Alan Wintermute, 8597. New York: Colnaghi, 1990.

Coypel, Antoine. Discours prononcez dans les conférences de l'Académie royale de peinture et de sculpture. Paris: De l'imprimerie de Jacques Collombat, 1721. Bibliothèque nationale de France, département Philosophie, histoire, sciences de l'homme, 4 Z Le Senne 943. https://gallica.bnf.fr/ark:/12148/bpt6k107991c.

Crow, Thomas. Painters and Public Life in Eighteenth-Century Paris. New Haven \& London: Yale University Press, 2000.

Darribère, Luc and Samy Jelil. Modes de XVIIIe siècle sous Louis XV et Madame de Pompadour. Editions Falbalas, 2014.

David, Elizabeth. Harvest of the Cold Months. New York: Penguin Group, 1994.

De Marchi, Neil and Hans J. Van Miegroet. "How Netherlandish paintings came to Paris." In Rubens, Van Dyck, Jordaens, et les autres: peintures baroques flamandes aux Musées royaux des beaux-arts de Belgique, by the Musée Marmottan Monet, 28-47. Paris: Musée Marmottan Monet, 2010.

—. "Transforming the Paris Art Market, 1718-1750." In Mapping Markets for Paintings in Europe, edited by Neil De Marchi and Hans J. Van Miegroet, 383-404. Turnhout, Belgium: Brepolis Publishers, 2006.

Décoratifs, Musée des Arts. "MAD Paris - Site officiel." Acessed Februrary 2018. http://madparis.fr/en.

DeJean, Joan. The Essence of Style. New York : Free Press, 2005.

Delaplanche, Jérôme. Joseph Parrocel, 1646-1704. Paris: Arthena, 2006.

Deloynes, Jean-Charles. Critique des vers de gresset sur cette exposition 1737. Bibliothèque nationale de France, département Estampes et photographie, RESERVE 8-YA3-27 (47, 1206). https://gallica.bnf.fr/ ark:/12148/btv1b10546578q.

-. Exposition a la place Dauphine le jour de la fete Dieu, 1722. Bibliothèque nationale de France, 8-YA3-27 (46, 1185). https://gallica.bnf.fr/ ark:/12148/btv1b10536019g.

-. Exposition de tableaux, dessins, sculptures, gravures et autres ouvrages des Peintres, Sculpteurs et graveurs de l'academie royale de Peinture et de Sculpture. 1737 : Mercure de France. Bibliothèque nationale de France, département Estampes et photographie, RESERVE 8-YA3-27 (47, 1203). https://gallica.bnf.fr/ ark:/12148/btv1b10546562m.

-. Exposition des peintures, sculptures et gravures au salon du louvre le 25 aout 1742. Mercure de France. Bibliothèque nationale de France, département Estampes et 
photographie, RESERVE 8-YA3-27 (47, 1216). https://gallica.bnf.fr/ ark:/12148/btv1b105466158.

- Exposition des tableaux, sculpture et autres ouvrages de messieurs les Peintres, Sculpteurs et graveurs de l'academie royale establie a paris sous la protection $d u$ roi 1738, Mercure de France. Bibliothèque nationale de France, département Estampes et photographie, RESERVE 8-YA3-27 (47, 1207). https://gallica.bnf.fr/ ark:/12148/btv1b10546584b.

Delpierre, Madeleine. Dress in France in the Eigheenth Century. Translated by Caroline Beamish. New Haven: Yale University Press, 1997.

Dézallier d'Argenville, Antoine-Joseph. Abrégé de la vie des plus fameux peintres, tome 4. Paris: Chez de Bure, 1762.

https://books.google.com/books?id=zRtbAAAAQAAJ\&printsec=frontcover\&sou $\mathrm{rce}=\mathrm{gbs} \_\mathrm{ge} \_$summary_r$\& \mathrm{cad}=0 \# \mathrm{v}=$ onepage $\& \mathrm{q} \& \mathrm{f}=\mathrm{false}$

Diderot, Denis. Encyclopédie ou Dictionnaire raisonné des sciences, des arts et des métiers, volume 12. Paris: Neufchastel, 1765. Bibliothèque nationale de France. https://gallica.bnf.fr/ ark:/12148/bpt6k505440.

Droguet, Vincent. Louis XV à Fontainebleau. Paris: Réunion des musées nationaux, 2016.

Du Bois de Saint-Gelais, Louis-François. Description des tableaux du Palais-Royal, avec la vie des peintres à la tête de leurs ouvrages, dédiée à Mgr. le duc d'Orléans. Paris: Chez d'Houry, 1737. Bibliothèque nationale de France, département Arsenal, RESERVE 8-S-14882. https://gallica.bnf.fr/ark:/12148/bpt6k1510602j.

Dubin, Nina L. "Man of Numbers." In Casanova: The Seduction of Europe, edited by Frederick Ilchman et al, 238-253. Boston: MFA Publications, Museum of Fine Arts, Boston, 2017.

Ducros, Louis. French Society in the Eighteenth Century. New York: Putnam's Sons, 1927.

Duffy, Stephen and Jo Hedley. The Wallace Collection's Pictures: A Complete Catalogue. London: Unicorn Press and Lindsay Fine Art Ltd, 2004.

Dufour, Philippe Sylvestre. Traitez Nouveaux \& Curieux du Café, du Thé et $d u$ Chocolate. La Haye: Chez Adrian Moetjens, 1685. https://books.google.com/books?id=6G4AAAAcAAJ\&printsec $=$ frontcover\&source $=g b s \_g e \_s u m m a r y \_r \& c a d=0 \# v=$ onepa ge\&q\&f=false

Dulau, Anne. "In Focus: Lady taking Tea and Woman on a Daybed." In Boucher \& Chardin: Masters of Modern Manners, edited by Anne Dulau, 8-25. Glasgow: University of Glasgow and Paul Holberton Publishing, 2008. 
Dulau, Anne, ed. Boucher \& Chardin: Masters of Modern Manners. Glasgow: University of Glasgow and Paul Holberton Publishing, 2008.

Dunoyer de Noirmont, Joseph-Anne-Emile-Edouard, baron. Histoire de la chasse en France depuis les temps les plus reculés jusqu'á la révolution. Paris: Ve Bouchard-Huzard, 1867-1868. Center for Research Libraries, Online Catalog. http://catalog.crl.edu/record=b2876913 S35.

Eatwell, Ann. "Tea à la Mode: The Fashion for Tea and Tea Equipage in London and Paris." In Boucher \& Chardin: Masters of Modern Manners, edited by Anne Dulau, 50-88. Glasgow: University of Glasgow and Paul Holberton publishing, 2008.

Eidelberg, Martin. "Gabriel Huquier - Friend of Foe of Watteau?" The Print Collector's Newsletter 158-164, 1984.

Eidelberg, Martin. "The Case of the Vanishing Watteau." Gazette des Beaux-Arts 138 no 1590/91 (July/August 2001): 15-40.

Eisler, Colin. Paintings from the Samuel H. Kress Collections: European Schools Excluding Italian. Oxford: Phaidon Press, 1977.

Elias, Norbert. The Civilizing Process. Translated by Edmund Jephcott. Cambridge, MA: Blackwell Publishers, 1994.

- The Court Society. Translated by Edmund Jephcott. New York: Pantheon Books, 1983.

Engerand, Fernand. Inventaire des tableaux commandés et achetés par la Direction des Bâtiments du Roi (1709-1792). Paris: E. Leroux, 1900. Comité des travaux historiques et scientifiques (CTHS), 2012-167520. https://gallica.bnf.fr/ark:/12148/bpt6k6340828v.

Erker, Nicholas Ryan. Pieter Bruegel the Elder's The Months: A Perspective. Order No. 1589429, University of Missouri - Kansas City, 2015.

http://proxy.mul.missouri.edu/login?url=https://search-proquestcom.proxy.mul.missouri.edu/docview/1691799525 accountid=14576.

Faust, Miklos and Béla Timon. "Origin and Dissemination of Peach." Horticultural Review, Vol. 17 (1995): 331-379.

Fink, Beatrice. Les liasons savoureurses. Saint-Étienne: Publications de l'Université de Saint-Étienne, 1995.

Forster, Robert and Orest Ranum, eds. Food and Drink in History. Translated by Elborg Forster and Patricia M. Ranum. Baltimore: The Johns Hopkins University Press, 1979. 
Fouilloux, Jacque de. La Venerie. Paris: Chez Abel l'Angelier, 1601. Bibliothèque nationale de France, département Arsenal, RESERVE 8-NF-32009. https://gallica.bnf.fr/ark:/12148/bpt6k1510946r.

Franklin, Alfred. La Vie Privée d'Autrefois: La Cuisine. Paris: E. Plon, Nourrit, 18871902. Bibliothèque nationale de France. https://gallica.bnf.fr/ ark:/12148/bpt6k2025252.

—. La Vie Privée d'Autrefois: Le café, le thé \& le chocolat. Paris: E. Plon, Nourrit et Cie, Imprimeurs-Editeurs, 1893. Bibliothèque nationale de France. https://gallica.bnf.fr/ ark:/12148/bpt6k204416b.

Freund, Amy. "Men and Hunting Guns in Eighteenth-Century France." In Materializing Gender in Eighteenth-Century Europe, edited by Jennifer G. and Heidi A. Strobel Germann, 17-33. Burlington, VT: Ashgate Publishing Company, 2016.

Fripp, Jessica L., Armadine Gorse, Nathalie Manceau, and Nina Struckmeyer. Artistes, savants, et amateurs: Art et sociablilité at XVIIIe siècle (1715-1815). Paris: Mare \& Martin, 2016.

Fromageau, Jérôme. "Droit de chasse et édits royaux." In De Chasse et d'Épée: le décor de l'appartement du roi à Marly, 1683-1750, by Musée-Promenade Marly-LeRoi-Louveciennes, 104-113. Paris: Éditions L'Inventaire, 1999.

Gaffet, Antoine, sieur de La Brifardière. Nouveau traité de venerie contenant la chasse du cerf, celles du chevreuil, du sanglier, du loup, du lievre et du renard. Paris: Nyon, Danonneville et Guillyn, 1750. https://books.google.com/books?id=X4Y7AAAAcAAJ\&printsec=frontcover\&so urce $=$ gbs_ge_summary_r\&cad $=0 \# \mathrm{v}=$ onepage $\& \mathrm{q} \& \mathrm{f}=$ false

Galerie Cailleux. François Boucher: Premier Peintre de Roi, 1703-1770. Paris: Galerie Cailleux, 1964.

Garlova, Maria. "Catherine the Great's Collections of Paintings: The Purchase of Old Masters and the Acquisition of Contemporary Works of Art." In Catherine the Great: an enlightened Empress, by the National Museums Scotland, 83-99. Edinburgh: NMS Enterprises, 2012.

Garnier-Pelle, Nicole. Chantilly, Museé Condé: Peintures du XVIIIe siècle. Paris: Editions de la Réunion des museés nationaux, 1995.

Gétreau, Florence. Musée Jacquemart-André Peintures et Dessins de l'école Francaise. Paris: Michel de Maule, 2011.

Gibson, Walter S. Pleasant Places: The Rustic Landscape from Bruegel to Ruisdael. Berkley: University of California Press, 2000.

Gilliers, Joseph. Le Cannameliste Français. Nancy: J.-B.-H. Leclerc, 1768. Bibliothèque nationale de France, département Réserve des livres rares, Résac. V-11204. https://gallica.bnf.fr/ ark:/12148/bpt6k105074g. 
Glorieux, Guillaume. Le Château de Condé. Paris: Somogy éditions d'art, 2004.

—. "Watteau et le Nord." In Watteau et la fête galante: Musée des beaux-arts de Valenciennes, 5 mars-14 juin 2004, 45-56. Paris: Éditions de la Réunion des musées nationaux, 2004.

Goncourt, Edmond and Jules. L'art au XVIIIe siècle: séries I, II, III. Paris: G. Charpentier, Éditeur, 1881. https://books.google.com/books?id=Hn1utBpTGBsC\&dq=goncourt\&pg=PP11\#v $=$ onepage $\& \mathrm{q}=$ goncourt $\& \mathrm{f}=$ false

Goodman, Elise. Rubens: the Garden of love as "Conversatie à la mode." Amsterdam/Philadelphia: John Benjamins Publishing Company, 1992.

Grasselli, Margaret Morgan and Pierre Rosenberg with the assistance of Nicole Parmantier. Watteau: 1684-1721. Washington: National Gallery of Art, 1984.

Gritsay, Natalya. "Pages from the History of the Hermitage Collection of Flemish Painting." In Rubens, Van Dyck \& Jordaens: Flemish Painters from the Hermitage, by the Hermitage Museum, 11-13. Amsterdam: Kunstdrukkerij Mercurius, 2011.

Groom, Susanne. At the King's Table: Royal Dining Through the Ages. London: Merrell Publishers Limited, 2013.

Guiffrey, J.J. Éloge de Lancret, peintre de Roi. Paris: Rapilly, c. 1874. https://books.google.com/books?id=OvoGAAAAQAAJ\&pg=PA67\&dq=sovot\&e $\mathrm{i}=\mathrm{NCpSW4rZIJW} 8-\mathrm{wHL}-\mathrm{qaADw} \& \mathrm{~cd}=3 \# \mathrm{v}=$ onepage $\& \mathrm{q} \& \mathrm{f}=$ false

Hellman, Mimi. "Furniture, Sociability, and the Work of Leisure in Eighteenth-Century France." Eighteenth-Century Studies Vol. 32, No. 4 (Summer 1999): 415-445.

—. "Of water and chocolate." Gastronomica: The Journal of Critical Food Studies, Vol. 4 No. 4 (Fall 2004): 9-11. University of California Press. doi:10.1525/gfc.2004.4.4.9.

—. "The Joy of Sets: The Uses of Seriality in the French Interior." In Furnishing the Eighteenth Century: What Furniture Can Tell Us About the European and American Past, edited by Dena Goodman and Kathryn Norberg, 129-53. New York and London: Routledge, 2006.

Herda-Mousseaux, Rose-Marie. "Thé, café ou chocolat?" In Thé, Café ou Chocolat? Les Boissons Exotiques à Paris au XVIIIe Siècle, by the Cognacq-Jay Musée, 7-29. Paris: Paris Musées, 2015.

Hermitage Amsterdam. Rubens, van Dyck, \& Jordaens: Flemish Painters from the Hermitage. Amsterdam: Museumshop Hermitage Amsterdam, 2011. 
Hohenegger, Beatrice.."The Tea Craze in the West." In Steeped in History: The Art of Tea, edited by Beatrice Hohenegger, 126-135. Los Angeles: The Fowler Museum at UCLA, 2009.

Hohenegger, Beatrice, ed. Steeped in History. Los Angeles: Fowler Museum at UCLA, 2009.

Holmes, Mary Tavener. "Deux chefs-d'oeuvre de Nicolas Lancret (1690-1743)." Revue du Louvre et des musées de France, 41 (1991): 40-42.

Holmes, Mary Tavener. "Katalog: Nicolas Lancret." In Französische Gemälde I: Watteau, Pater, Lancret, Lajoüe, edited by Christoph Martin Vogtherr, 449-632. Berlin: Akademie Verlag, 2011.

Holmes, Mary Tavener. "Lancret, décorateur des "petits cabinets" de Louis XV à Versailles." L'oeil: l'art sous toutes ses formes, No. 356 (Mars 1985): 24-31.

Holmes, Mary Tavener. "Nicolas Lancret and the Tale of Three Collectors." In French Art of the Eighteenth Century: The Michael L. Rosenberg Lecture Series at the Dallas Museum of Art, edited by Heather MacDonald. New Haven: Yale University Press, 2016.

—. Nicolas Lancret, 1690-1743. New York: Harry N. Abrams, 1991.

—. Nicolas Lancret: Dance Before a Fountain. Los Angeles: Getty Publications, 2006.

Hyde, Melissa and Mark Ledbury, eds. Rethinking Boucher. Los Angeles: Getty Publication, 2006.

Hyde, Melissa. Making up the rococo: François Boucher and his critics. Los Angeles, CA: Getty Research Institute, 2006.

Ilchman, Frederick et al., eds. Casanova : the seduction of Europe. Boston: MFA Publications, Museum of Fine Arts, Boston, 2017.

Ingamells, John. The Wallace Collection. London: Scala Publications Ltd, 1990.

Jal, Auguste. Dictionnaire Critique de Biographie et d'Histoire. Paris: Henri Plon, 1872. https://books.google.com/books?id=BC1Yn4hhFKEC\&printsec=frontcover\&dq= Dictionnaire+Critique+de+Biographie + et + d\%27Histoire $\& h l=e n \& s a=X \& v e d=0 a h$ UKEwizl5LwuqzcAhXo54MKHSlAC3cQ6AEIKTAA\#v=onepage\&q\&f=false

Jones, Christine A. "Exotic Edibles: Coffee, Tea, Chocolate, and the Early Modern French How-to." Journal of Medieval and Early Modern Studies, 43:3 (Fall 2013): 623-653.

Keyes, George S. Esaias van de Velde, 1587-1630. Doornspijk: Davaco Publishers, 1894.

Klinge, Margret. David Teniers the Younger: Paintings and Drawings. Antwerp: SnoeckDucaju \& Zoon, 1991. 
La Chapelle, Vincent. Le Cuisinier Moderne. Paris: A La Haye, 1735. Bibliothèque nationale de France, département Arsenal, 8-S-9808 (2). https://gallica.bnf.fr/ark:/12148/bpt6k1042601c.

La Curne de Sainte-Palaye, Jean-Baptiste de. Catalogue des tableaux du cabinet de $M$. Crozat, baron de Thiers. Paris: de Bure aîné, 1755. Bibliothèque nationale de France, département Littérature et art, V-24832. https://gallica.bnf.fr/ ark:/12148/bpt6k65649702.

L'Académie Royale. Explication des Peintures, Sculptures, et Autres Ouvrages de Messieurs de L'Academie Royale. Paris: Jacques Collombay, I. Imprimeur du Roy, 1742. Bibliothèque nationale de France, département Estampes et photographie, RESERVE 8-YA3-27 (64). https://gallica.bnf.fr/ark:/12148/btv1b10542923j.

-. Explication des peintures, sculptures, et autres ouvrages de Messieurs de l'Academie Royale. Paris: l'Imprimerie de Jacques Collombat, 1739. Bibliothèque nationale de France, RESERVE 8-YA3-27 (1,9). https://gallica.bnf.fr/ark:/12148/btv1b84427785.

- Explication des peintures, sculptures, et autres ouvrages de messieurs de l'Académie royale. Paris: Jacques Collombat, 1737. Bibliothèque nationale de France, département Estampes et photographie, RESERVE 8-YA3-27 (64). https://gallica.bnf.fr/ark:/12148/btv1b105429045.

Larmessin, Nicolas de, IV. "Print of Le Matin after Nicolas Lancret." Google Arts \& Culture, Collection of the National Gallery of Art, Washington D.C. Print, 1741. https://artsandculture.google.com/asset/le-matin/LQGR_YxDM1PsWw.

Le Corbeiller, Clare and Linda H. Roth. French Eighteenth-Century Porcelain at the Wadsworth Atheneum. Hartford, CT, 2000.

Le Verrier de la Conterie, Jean-Baptiste-Jacques. L'école de la chasse aux chiens courrants. Paris: Emile Nourry, 1932. Bibliothèque nationale de France, département Sciences et techniques, 4-S-3777 (5). https://gallica.bnf.fr/ark:/12148/bpt6k6438655h.

Léribault, Christophe. Jean-François de Troy (1679-1752). Paris: Association pour da diffusion de l'Histoire de l'Art, 2002.

"Les Musées d'Angers." http://musees.angers.fr/accueil/index.html.

Les musées d'Angers. "Collections en ligne : Les musées d'Angers : Une danse champêtre." https://ow-mba.angers.fr/ow4/mba18022013/voir.xsp?id=00101251\&qid=sdx_q1\&n=3\&e.

—. "Collections en ligne : Les musées d'Angers : Un festin de noces de villages." http://musees.angers.fr/collections/collections-en-ligne/index.html. 
Levey, Michael. "A Watteau Rediscovered: 'Le Printems' for Crozat." The Burlington Magazine, Vol. 106, No. 731 (Feburary 1964): 52-59.

-. Painting and Sculpture in France, 1700-1789. New Haven: Yale University Press, 1993.

Liddell, Caroline and Robin Weir. Ices: The Definitive Guide. London: Hodder \& Stoughton, 1993.

Luynes, Charles-Philippe d'Albert, duc de (1695-1758). Mémoires du duc de Luynes sur la Cour de Louis XV (1735-1758). Paris: Frimin Didot Frères, 1860-1865. Bibliothèque nationale de France. https://gallica.bnf.fr/ark:/12148/bpt6k2064267.

Lyna, Dries and Filip Vermeylen. "Rubens for Sale. Art Auctions in Antwerp during the Seventeenth and Eighteenth Centuries." In Art Auctions and Dealers: The Dissemination of Netherlandish Art during the Ancien Régime, edited by Dries Lyna, Filip Vermeylen and Hans Vlieghe, 139-153. Tourhout: Brepolis Publishers, 2009.

Malaguzzi, Silvia.. Food and feasting in art. Translated by Brian Phillips. Los Angeles: G. Paul Getty Museum, 2008.

Marie, Alfred and Jeanne Marie. Versailles au temps de Louis XV, 1715-1745. Paris: Impr. nationale, 1984.

Martin, Meredith. Dairy Queens. Cambridge, Mass: Harvard University Press, 2011.

Massialot, François. Le Cuisinier Rö̈al et Bourgeois. Paris: Chez Claude Prudhomme, 1705. Bibliothèque nationale de France, département Arsenal, Ars. 8-S-9793. https://gallica.bnf.fr/ark:/12148/bpt6k108571q.

-. Nouvelle Instruction pour les Confitures, les liqueurs, et les fruits. Paris: Chez Saugrain, 1760.

https://books.google.com/books?id=J_M6AAAAcAAJ\&dq=massialot\&pg=PP19 $\# \mathrm{v}=$ onepage $\& \mathrm{q}=$ massialot $\& \mathrm{f}=$ false.

Mennell, Stephen. All Manners of Food: Eating and Taste in England and France from the Middle Ages to the Present. New York: B. Blackwell, 1985.

Mercure de France, Vol. 2, (Juin 1738). Paris. Bibliothèque nationale de France, département Philosophie, histoire, sciences de l'homme, 8-LC2-39 (DOUBLES VERSAILLES). https://gallica.bnf.fr/ark:/12148/bpt6k6476167g.

Merveilleux du Vignaux, François. Encyclopédie de la Vénerie Francaise. Paris: FirminDidot, 1961.

Michel, Patrick. "French Collectors and the Taste for Flemish Painting during the Eighteenth Century." In Art Auctions and Dealers: The Dissemination of Netherlandish Art during the Ancien Régime, edited by Dries Lyna, Filip Vermeylen, and Hans Vlieghe, 127-137. Tourhout: Brepols Publishers, 2009. 
Miegroet, Hans J. van. ""The Twelve Months" Reconsidered: How a Drawing by Pieter Stevens clafifies a Bruegel Enigma." Similous: Netherlands Quarterly for the History of Art, Vol. 16, No 1 (1986) 29-35.

Ministère de la Culture. "Base Joconde." http://www2.culture.gouv.fr/documentation/joconde/fr/pres.htm.

Moxham, Roy. Tea: Addiction, Exploration and Empire. New York: Carroll \& Graf Publishers, 2003.

Musée Cognacq-Jay. Thé, Café ou Chocolat? Les Boissons Exotiques à Paris au XVIIIe Siècle. Paris: Paris Musées, 2015.

Musée Condé. Chasse à courre, chasse de cour : fastes de la vénerie princière à Chantilly au temps des Condés et des Orléans, 1659-1910. Tournai: Renaissance du livre, 2004.

Musée des Beaux-Arts d'Angers. Chef-d'oeuvre du musée des Beaux-Arts d'Angers. Paris: Somogy éditions d'art, 2004.

Musée des Beaux-Arts de Valenciennes. Florilège: De Watteau à Fragonard, Peintures du XVIIIe siècle du musée d'Angers. Valenciennes: Musée de Beaux-Arts de Valenciennes, 2001.

—. Watteau et la fête galante. Paris: Éditions de la Réunion des musées nationaux, 2004.

Musée Marmottan. Rubens, Van Dyck, Jordaens, et les autres: peintures baroques flamandes aux Musées royaux des beaux-arts de Belgique. Paris: Hazan: Musée Marmottan Monet, 2010.

Musées de Strasbourg. "L’écureuse de cuivres." Last modified 2017. https://www.musees.strasbourg.eu/oeuvre-musees-strasbourg//entity/id/220372?_eu_strasbourg_portlet_entity_detail_EntityDetailPortlet_return $\mathrm{URL}=\mathrm{https} \% 3 \mathrm{~A} \% 2 \mathrm{~F} \% 2 \mathrm{Fwww} . \mathrm{musees}$.strasbourg.eu\%2Frecherche\%3Fp_p_id \% 3Deu_strasbourg_portlet_search_asset_SearchAssetPor.

"museum-digital: deutschland." Accessed January 2018. https://www.museumdigital.de/index.php?t=start.

National Museums Scotland. Catherine the Great: An Enlightened Empress. Edinburgh: NMS Enterprises Limited, 2012.

Neild, Robert. The English, the French, and the Oyster. London: Quiller Press Ltd, 1995.

Netherlandish Yearbook for the History of Art 2013. Art and Migration: Netherlandish Artists on the Move, 1400-1750. Leiden: Brill, 2014.

Neufville de Brunaubois-Montador, Jean-Florent-Joseph de. Description raisonnée des tableaux exposés au Salon du Louvre, Lettre à Madame la marquise de S.P.R. Paris: De l'Imprimerie de Claude-François Simon, fils, 1739. Bibliothèque 
nationale de France, département Littérature et art, RESERVE 8-YA3-27 (1,11). https://gallica.bnf.fr/ ark:/12148/btv1b8442783g.

Patriarca, Silvana. Italian Vices. Cambridge: Cambridge University Press, 2010.

Pinkard, Susan. A Revolution in Taste: The rise of French Cuisine. New York: Cambridge University Press, 2010.

Plax, Julie Ann. "Fêting the Hunt in Eighteenth-Century Painting." In Artistes, savants et amateurs : Art et sociabilité au XVIIIe siècle (1715-1815), edited by Jessica Frip, Amandine Gorse, Nathalie Manceau, and Nina Struckmeyer p, 127-137. Paris: Mare et Martin, 2016.

- Watteau and the Cultural Politics of Eighteenth-Century France. New York: Cambridge University Press, 2000.

Posner, Donald. Antoine Watteau. Ithaca, NY: Cornell University Press, 1984.

Pradié-Ottinger, Bénédicte. L'Art et la Chasse. Tournai: La Renaissance du Livre, 2002.

Pullins, David. "Stubbs, Vernet \& Boucher Share a Canvas: Workshops, Authorship \& the Status of Painting." Journal18 1 (Spring 2016). http://www.journal18.org/334.

—. "The individual's triumph: the eighteenth-century consolidation of authorship and art historiography." Journal of Art Historiography, Vol 16 (2017): 1-26.

Quinzio, Jeri. Of Sugar and Snow : A History of Ice Cream Making. Berkeley, CA: University of California Press, 2009. EBSCOhost.

Radisich, Paula. Pastiche, fashion, and galanterie in Chardin's genre subjects : looking smart. Lanham, Maryland: University of Delaware Press, 2013. ProQuest EBook Central.

Rémy, Pierre. Catalogue de tableaux, dont le plus grand nombre des bons maîtres des trois écoles, de peintures à gouache \& miniatures, dessins \& estampes en feuilles \& sous verres, livres \& suites d'estampes, après le décès de Madame Lancret, \& de $M^{* *}$, par P. Rémy, $c$. Paris : Frémin, 1782. Bibliothèque de l'Institut National d'Histoire de l'Art, collections Jacques Doucet, NUM CV01375_17820403. http://bibliotheque-numerique.inha.fr/idurl/1/19529.

Revel, Jean-François. Culture and Cuisine: A Journey Through the History of Food. Translated by Helen R. Lane. New York: Da Capo Press, 1982.

Ribeiro, Aileen. Dress in eighteenth-century Europe, 1415-1789. New York: Holmes \& Meier Publishers, Inc, 1984.

Riley, Gillian. A Feast for the Eyes. London: National Gallery Publications, 1997.

Riley, Gillian. "Lust, Fear, and Loathing on the Village Green." In The Oxford Symposium on Food and Cookery: The Meal 2001, edited by Harlan Walker, 201205. Prospect Books: London, 2002. 
Robuchon, Joël and Prosper Montagné, eds. Larousse gastronomique : the world's greatest culinary encyclopedia. New York: Clarkson Potter Publishers, 2009.

Roland Michel, Marianne. "Observations on Madame Lancret's Sale." The Burlington Magazine, Vol. 111, No. 801, Special Issue Devoted to Claude, Nicolas and Gaspard Poussin in Connection with the Claude Exhibition at the Hayward Gallery (December 1969): i-vi.

—. Watteau: An Artist of the Eigheenth Century. London: Trefoil Books Ltd, 1984.

Rosenberg, Pierre. French Paintings 1500-1825, The Fine Arts Museums of San Francisco. San Francisco: The Fine Arts Museums of San Francisco, 1987.

-. The Age of Louis XV: French Painting 1710-1774. Toldeo, Ohio: The Toledo Museum of Art, 1975.

Sahut, Marie-Catherine, Élisabeth Martin, and Claudia Sindaco-Domas. "Le Repas de chasse et Les Plaisirs du bain de Nicolas Lancret." Techne (2009-10):162-169.

Saint Louis Art Museum. "Peasant Interior with Woman at a Well." Accessed February 2018. http://emuseum.slam.org/objects/36913/peasant-interior-with-woman-at-awell; jsessionid=93B83A0DBCCA7D121652D092359A34AF?ctx=56b72c9817ae-4574-864b-b4efb369a87a\&idx=0.

Salnove, Robert. La Vénerie royale. Paris: A. de Sommaville, 1665. Bibliothèque nationale de France, département Réserve des livres rares, S-2948. https://gallica.bnf.fr/ ark:/12148/bpt6k87075963.

Salvadori, Philippe. La chasse sous l'Ancien Régime. Paris: Fayard, 1996.

—. La vie culturelle en France aux XVIe, XVIIe, XVIIIe siècles. Paris: Ophrys, 1999.

Schapira, David, Joel Schapira, and Karl Schapira. The Book of Coffee and Tea. New York: Saint Martin's Press, 1982.

Schivelbusch, Wolfgang. Tastes of Paradise: A Social History of Spices, Stimulants, and Intoxicants. Translated by David Jacobson. New York: Pantheon Books, 1992.

Sheriff, Mary D. Fragonard: Art and Eroticism. Chicago: University of Chicago Press, 1990.

—. "Introduction: The Mystique of Antoine Watteau." In Antoine Watteau: Perspectives on the Artist and Culture of the Time, edited by Mary D. Sheriff, 17-26. Newark: University of Delaware Press, 2006.

Sheriff, Mary D., ed. Antoine Watteau: Perspectives on the Artist and the Culture of his Time. Newark: University of Delaware Press, 2006.

Silver, Larry. Peasant Scenes and Landscapes. Philadelphia: University of Pennsylvannia Press, 2006. 
Smith, Woodruff D. "Tea and the Middle Class." In Steeped in History: The Art of Tea, edited by Beatrice Hohenegger, 136-151. Los Angeles: The Fowler Museum at UCLA, 2009.

Société archéologique et historique de l'Orléanais.. Bulletin de la Société archéologique et historique de l'Orléanais. Orléans, 1876. Bibliothèque nationale de France. http://gallica.bnf.fr/ark:/12148/bpt6k57183222.

Somof, Alexandre. Catalogue de la galerie des tableaux. Ecole anglaise et école française. Saint-Pétersbourg: Compagnie d'imprimerie artistique, 1899-1903. Bibliothèque de l'INHA / coll. J. Doucet, 2012-296079. http://catalogue.bnf.fr/ark:/12148/cb31383488r

Sotheby's Auctions. "lancret, nicolas fête ||| genre scene ||| sotheby's 115318lot78bpqen, April 28, 2015." Accessed 2018.

http://www.sothebys.com/en/auctions/ecatalogue/2015/mansion-overlookingroyal-park-115318/lot.63.html.

—. "lancret, nicolas wint ||| conversation piece ||| sotheby's n09812lot9jkgjen." February 01, 2018. Accessed 2018. http://www.sothebys.com/en/auctions/ecatalogue/2018/master-paintings-eveningsale-n09812/lot.69.html

Spary, E.C. Eating the Enlightenment: Food and Sciences in Paris. Chicago: University of Chicago Press, 2012.

—. "Liqueurs and the Luxury Marketplace in Eigheenth-Century Paris." In Materials and Expertise in Early Modern Europe, edited by Ursula Klein and E.C. Spary, 225255. Chicago: University of Chicago Press, 2010.

Spieth, Darius A. Revolutionary Paris and the Market for Netherlandish Art. Leiden: Brill, 2018.

Staatliche Kunsthalle Karlsruhe. David Teniers der Jungere, 1610-1690. Heidelberg: Kehrer, 2005.

Stewart, Alison G. Before Bruegel: Sebald Beham and the Origins of Peasant Festival Imagery. Burlington, VT: Ashgate Publishing Company, 2008.

Szanto, Mickaël. "Antwerp and the Paris Art Market in the Years 1620-1630." In Mapping Markets for Paintings in Europe 1450-1750, edited by Neil De Marchi and Hans J. Van Miegroet, 329-342. Turnhout, Belgium: Brepolis Publishers, 2006.

The Boston Museum of Fine Arts. "Luncheon Party in a Park." Accessed December 2017. http://www.mfa.org/collections/object/luncheon-party-in-a-park-33938.

The Getty Research Library. "Catalog: Madame Lancret." The Getty Provenance Index Databases. Accessed 2018. http://www.getty.edu/research/tools/provenance/search.html. 
"The Metropolitan Museum of Art." Accessed 2018. https://www.metmuseum.org/.

"The National Gallery, London." Accessed 2018. https://www.nationalgallery.org.uk/.

"The State Hermitage Museum." Accessed 2018. http://hermitage-www.hermitagemuseum.org/wps/portal/hermitage?lng=en.

"The Wallace Collection." Accessed 2018. http://www.wallacecollection.org/.

The Wallace Collection Online. "A Young Woman in a Kitchen." Accessed May 2017. http://wallacelive.wallacecollection.org/eMuseumPlus?service=ExternalInterface $\&$ module $=$ collection $\&$ objectId $=65312 \&$ viewType $=$ detail View .

"Toldedo Museum of Art." Accessed 2017. http://www.toledomuseum.org/.

Toussaint-Samat, Maguelonne. A History of Food. Translated by Anthea Bell. Cambridge, MA: Blackwell Publishers, 1992.

Trémolières, Antoine. L'art de la chasse: pour le divertissement de la noblesse, \& de tous ceux qui aiment cet excercise (republ. with an introduction by Pierre Lançon. Rodez: Societé des Lettres, Sciences et Arts de l'Aveyron, 1996 [1724]).

Trumble, Angus. "Tea and the Conversation Piece." In Steeped in History: The Art of Tea, by Beatrice Hohenegger Edited by, 152-157. Los Angeles: The Fowler Museum at UCLA, 2009.

Turner, Evan H. The Ackland Art Museum: A Handbook. Chapel Hill, NC: Mercantile Printing Company, 1983.

Venner, Dominique. Les Beaux-Arts de la Chasse. Jacques Grancher, 1992.

Vidal, Mary. Watteau's Painted Conversations. New Haven: Yale University Press, 1992.

Vogtherr, Christoph Martin and Mary Tavener Holmes, eds. De Watteau à Fragonard, les fêtes galantes. Bruxelles : Fonds Mercator, 2014.

Vogtherr, Christoph Martin, ed. Französische Gemälde I: Watteau, Pater, Lancret, Lajoüe. Berlin: Akademie Verlag, 2011.

Vogtherr, Christoph Martin. "Frédéric II de Prusse et sa collection de peintures francaises. Thèmes et perspectives de recherche." In Poussin, Watteau, Chardin, David..., edited by Pierre Rosenberg, 89-96. Paris: Éditions de la Réunion de musées nationaux, 2005.

-. "Moving on from Watteau: Jean-Baptiste Pater and the Transformation of the Fête Galante." In French Art of the Eighteenth Century: The Michael L. Rosenberg Lecture Series at the Dallas Museum of Art, edited by Heather MacDonald, 8193. New Haven: Yale University Press, 2016. 
—. 2008. "New Beginnings in French Genre Painting: de Troy, Chardin, Boucher." In Boucher \& Chardin: Masters of Modern Manners, by edited Anne Dulau, 26-49. Glasgow: University of Glasgow and Paul Holberton publishing.

Von Hoffmann, Viktoria. From Gluttony to Enlightentment: The World of Taste in Early Modern Europe. Urbana: University of Illinois Press, 2016.

Waddesdon Manor. "The Village Wedding - Waddesdon Manor." Accessed 2018. https://waddesdon.org.uk/the-collection/item/?id=475.

—. "The Wedding Breakfast - Waddesdon Manor." Accessesd 2018. https://waddesdon.org.uk/the-collection/item/?id=8606.

Wheaton, Barbara Ketcham. Savoring the Past, The French Kitchen and Table from 1300 to 1789. New York: Touchstone, 1983.

Wildenstein, Georges. Lancret. Paris: G. Servant, 1924.

—. Le Salon de 1725. Paris: Les Beaux-Arts, 1924.

Wile, Aaron. Watteau's Soldiers: Scenes of Military Life in Eigheenth-Century France. New York: The Frick Collection, 2016.

Williams, Sarah J. Sylvester. "Dining and Revelry in French Rococo Art." Order No. 1503909, University of Missouri - Kansas City, 2011. http://proxy.mul.missouri.edu/login?url=https://search-proquestcom.proxy.mul.missouri.edu/docview/916901654? accountid=14576.

Wintermute, Alan. Claude to Corot: The Development of Landscape Painting in France. New York: Colnaghi, 1990.

Wood, Roy C. The Sociology of the Meal. Edinburgh: Edinburgh University Press, 1995.

Yauville, Monseiur d'. Traité de vénerie. Paris: L'Imprimerie Royale, 1788. Bibliothèque nationale de France. https://gallica.bnf.fr/ark:/12148/bpt6k1510984f.

You, Yao-Fen, ed. Coffee, Tea, and Chocolate: Consuming the World. New Haven: Yale University Press, 2016.

You, Yao-Fen. "From Novelty to Necessity: The Europeanization of Coffee, Tea, and Chocolate." In Coffee, Tea, and Chocolate: Consuming the World, edited by YaoFen You, 11-67. New Haven: Yale University Press, 2016.

Ziskin, Rochelle. Sheltering Art: collecting and social identity in early eighteenth-century Paris. University Park, PA: Pennsylvania State University Press, 2012. 
Images

Figure 1: Antoine Watteau, Pélerinage à l'île de Cythère, 1717. Oil on canvas, 129 x 194 cm, Musée du Louvre, Paris. 


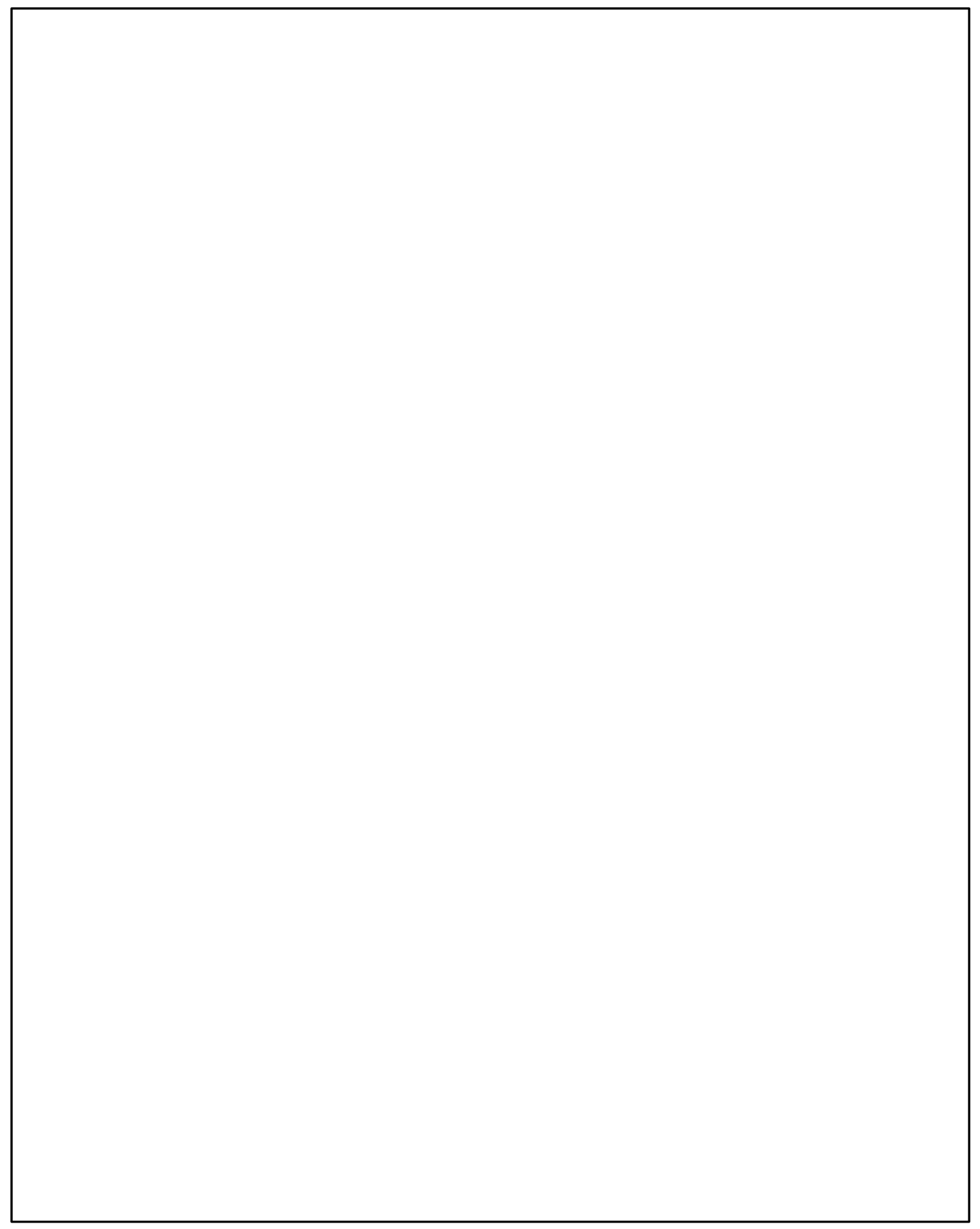

Figure 2: Nicolas Lancret, Gallant Conversation, 1719. Oil on canvas, 68.3 x $53.5 \mathrm{~cm}$, The Wallace Collection, London. 


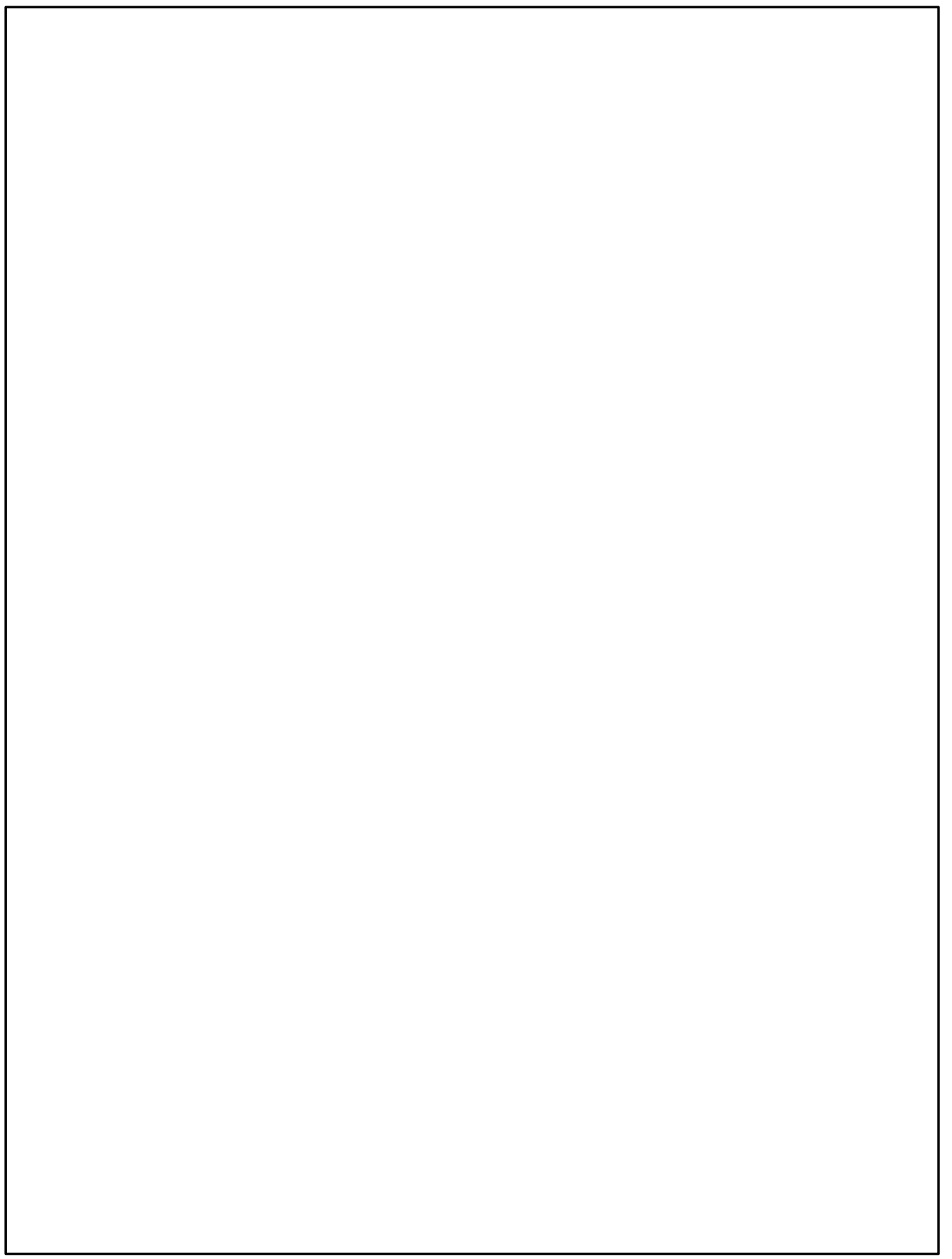

Figure 3: Antoine Watteau, Harlequin and Colombine (Voulez-Vous triompher des Belles?), c.1717. Oil on oak panel, 36 x $24.9 \mathrm{~cm}$, The Wallace Collection, London. 
Figure 4: Nicolas Lancret, The Peepshow Man, 1743. Oil on Canvas, 52 x $77.5 \mathrm{~cm}$, Stifung Preußische Schlösser und Gärten, Berlin-Brandenburgh, Berlin, Scholss Charlotttenburg. 


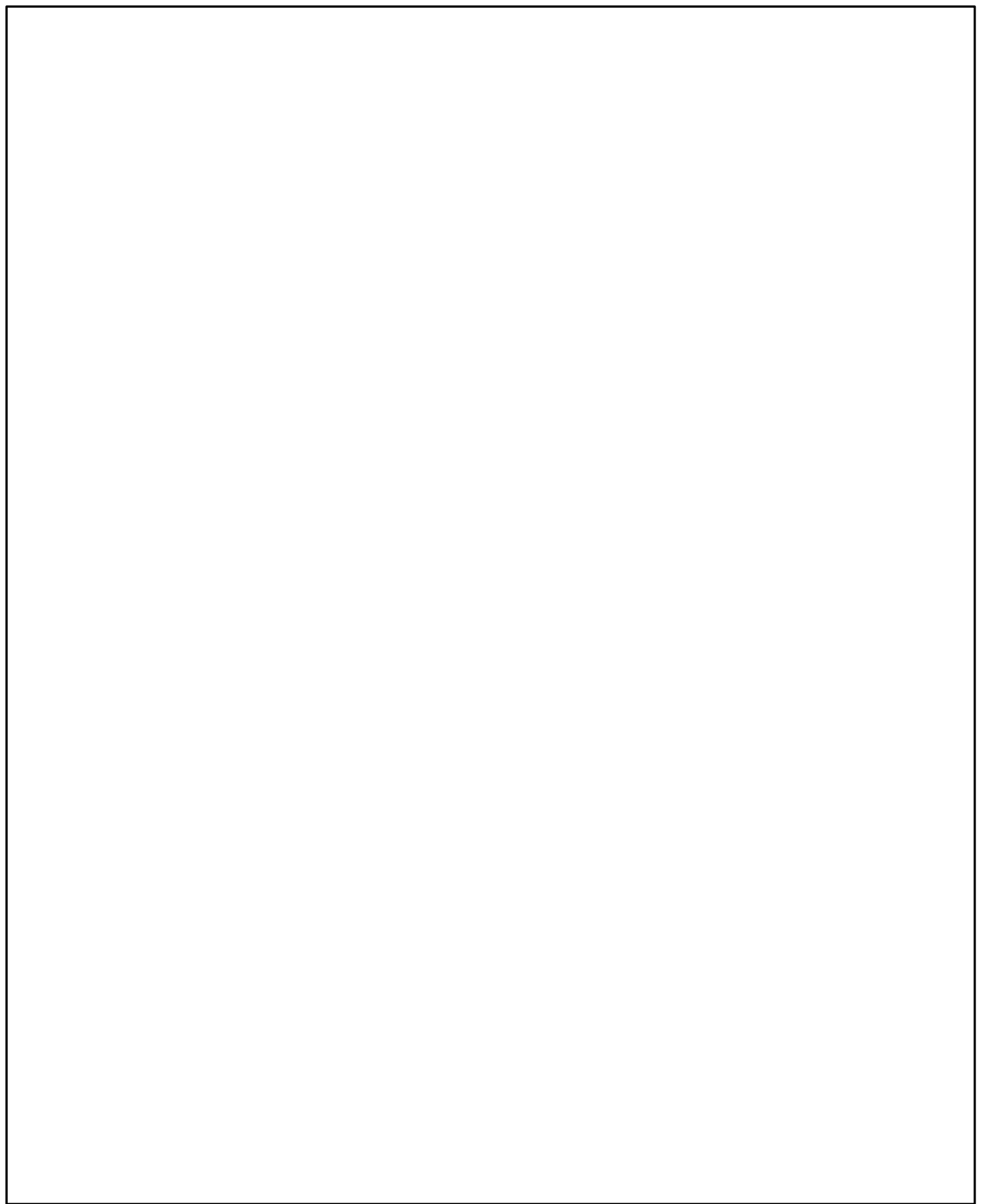

Figure 5: Antoine Watteau, La Marmotte, 1716. Oil on Canvas, $40.5 \times 32.5 \mathrm{~cm}$, The Hermitage Museum, Saint Petersburg. 


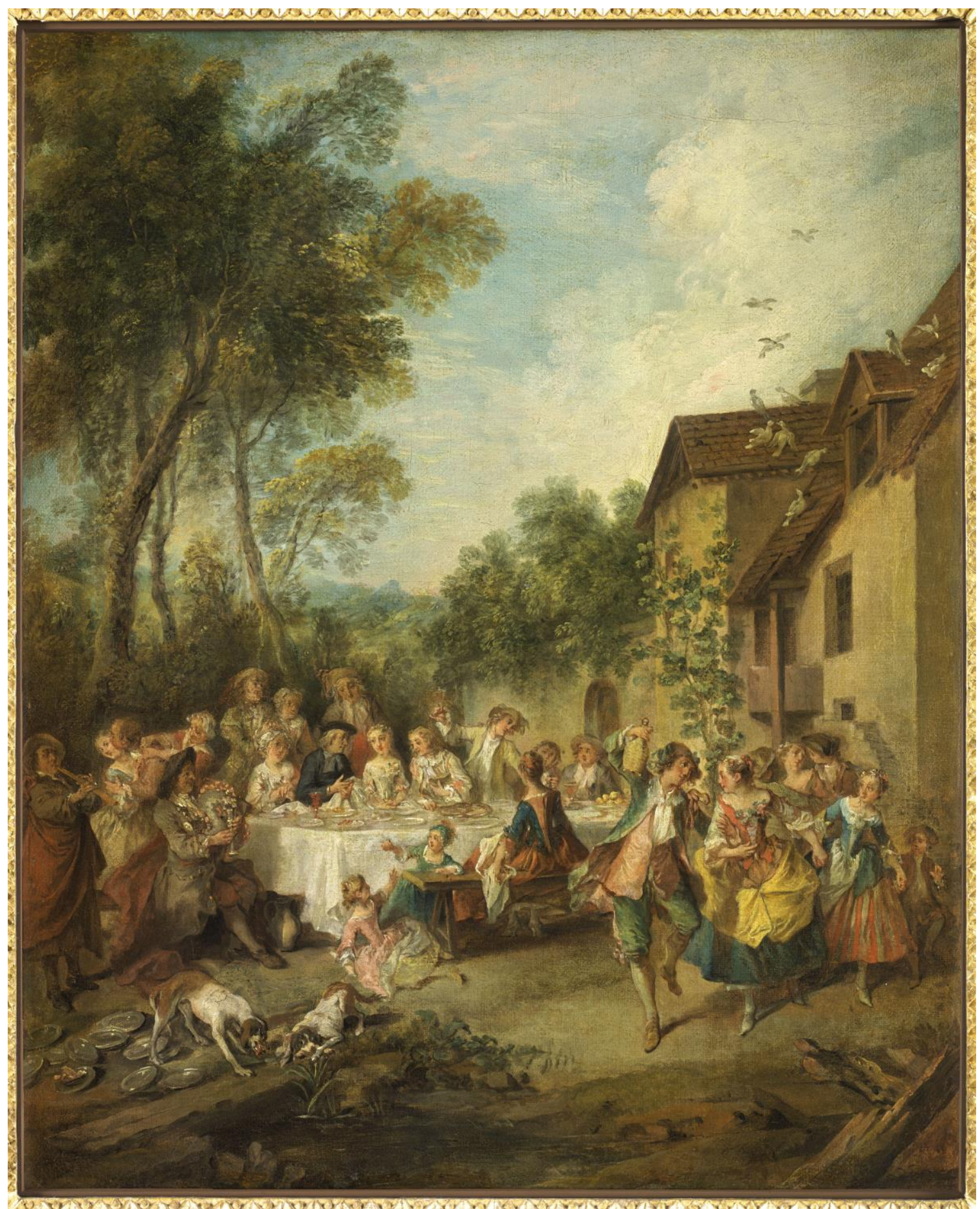

Figure 6: Nicolas Lancret, Le Repas de Noce au Village (Wedding Celebrations in a Village), 1735. Oil on Canvas, 43.3 x $35.5 \mathrm{~cm}$, Musée d'Angers, Angers, France. MBAJ96J1881P. Photo : Beoît Touchard. CRMN-Grand Palais/Art Resource, NY. 
Figure 7: Nicolas Lancret, The Wedding Breakfast, 1737-40. Oil on Canvas, 44.2 x 58.2 $\mathrm{cm}$, Waddesdon Manor, England. 


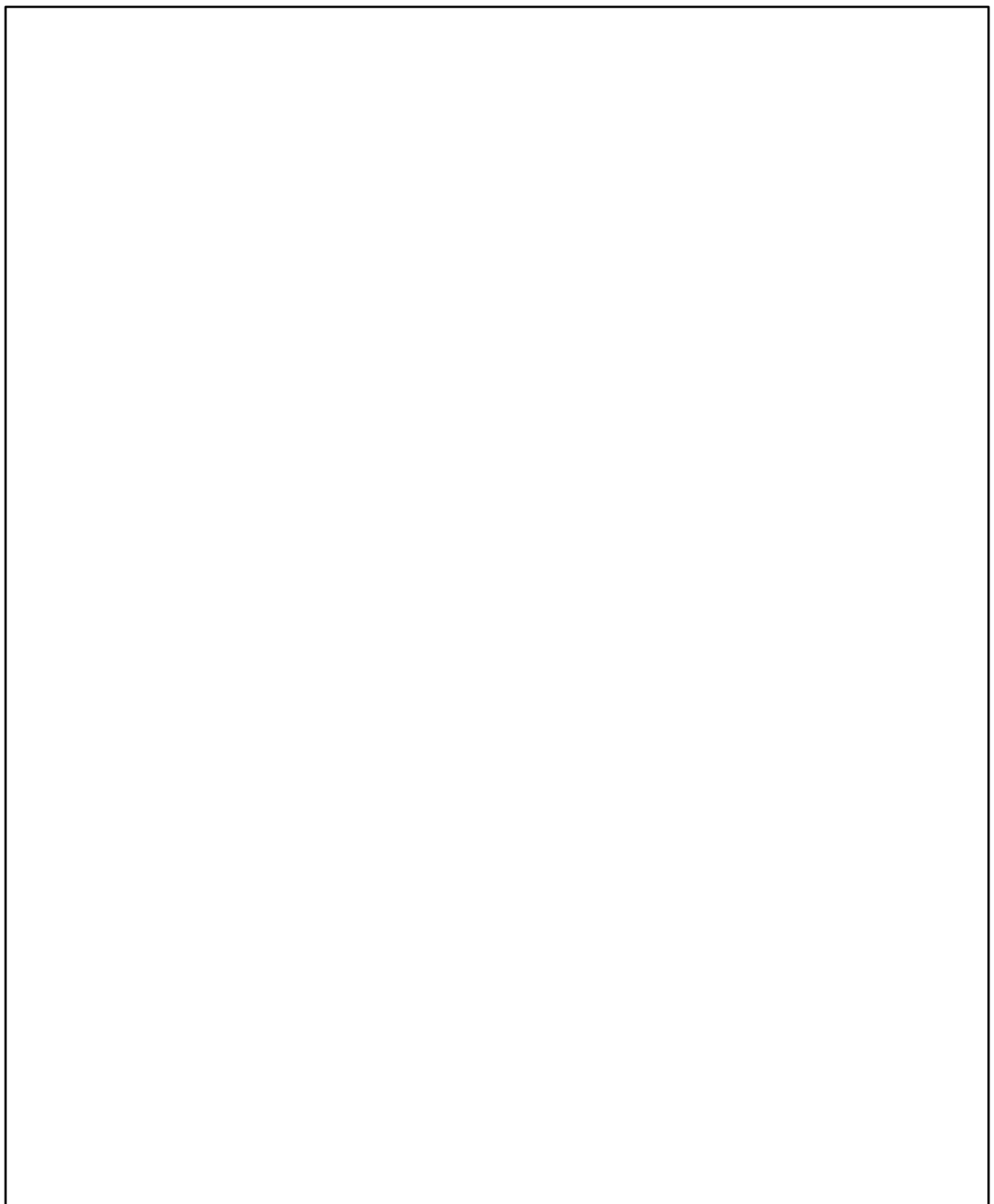

Figure 8: Engraving after Antoine Watteau, Le repas de champagne (The Country Meal), c. 1700-1712. Original, 64.8 x $46.8 \mathrm{~cm}$, Trustees of the British Museum, London. 


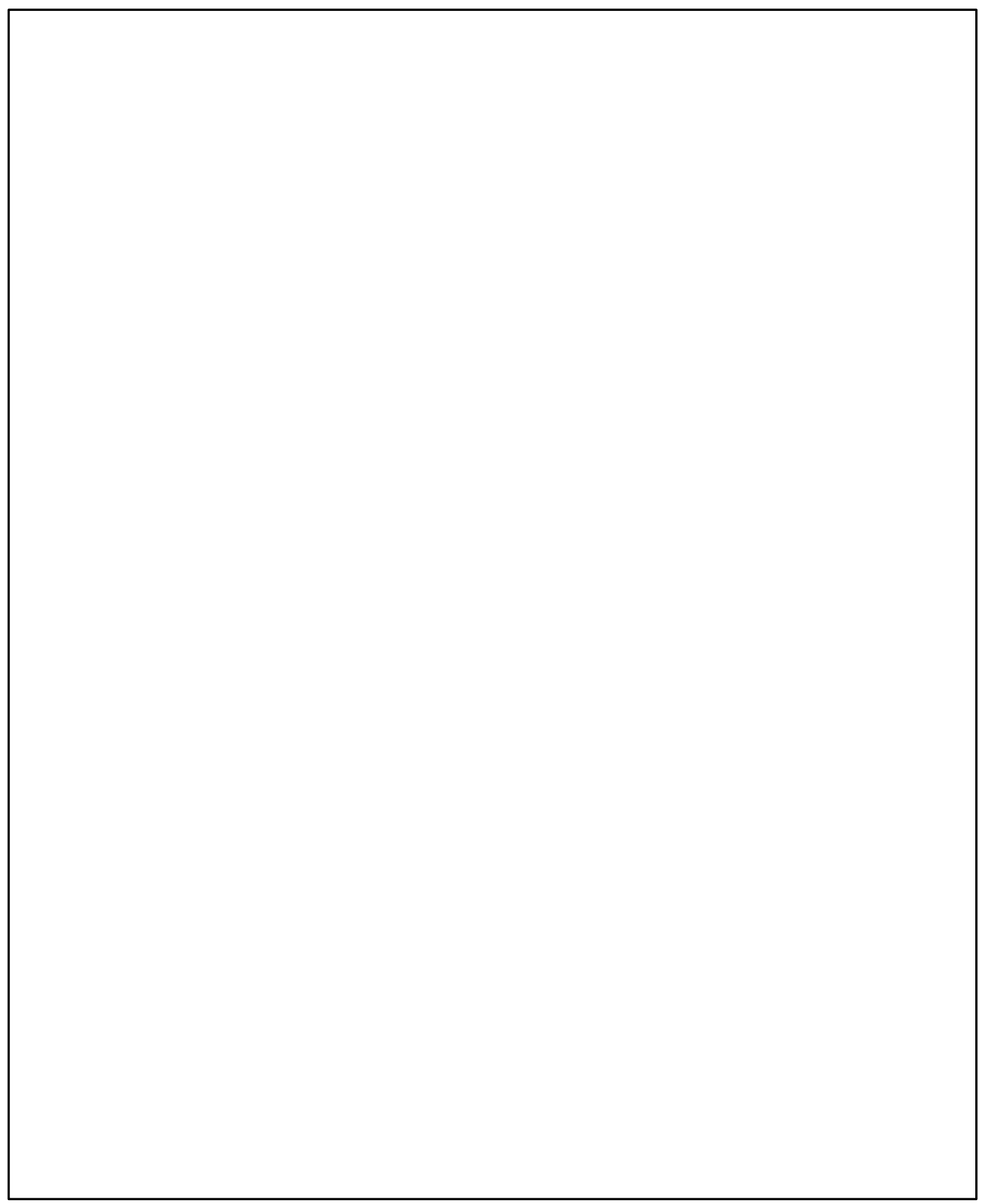

Figure 9: Antoine Watteau, La Cuisinière (The cook), c. 1700-1712. Oil on Canvas, 53 x $44 \mathrm{~cm}$, Musée des Beaux-Arts, Strasbourg, France. 
Figure 10: Engraving after Antoine Watteau, Retour de guinguette (Return from the Tavern), c. 1700-1712. Original 24.5 x $37.7 \mathrm{~cm}$, Trustees of the British Museum, London. 


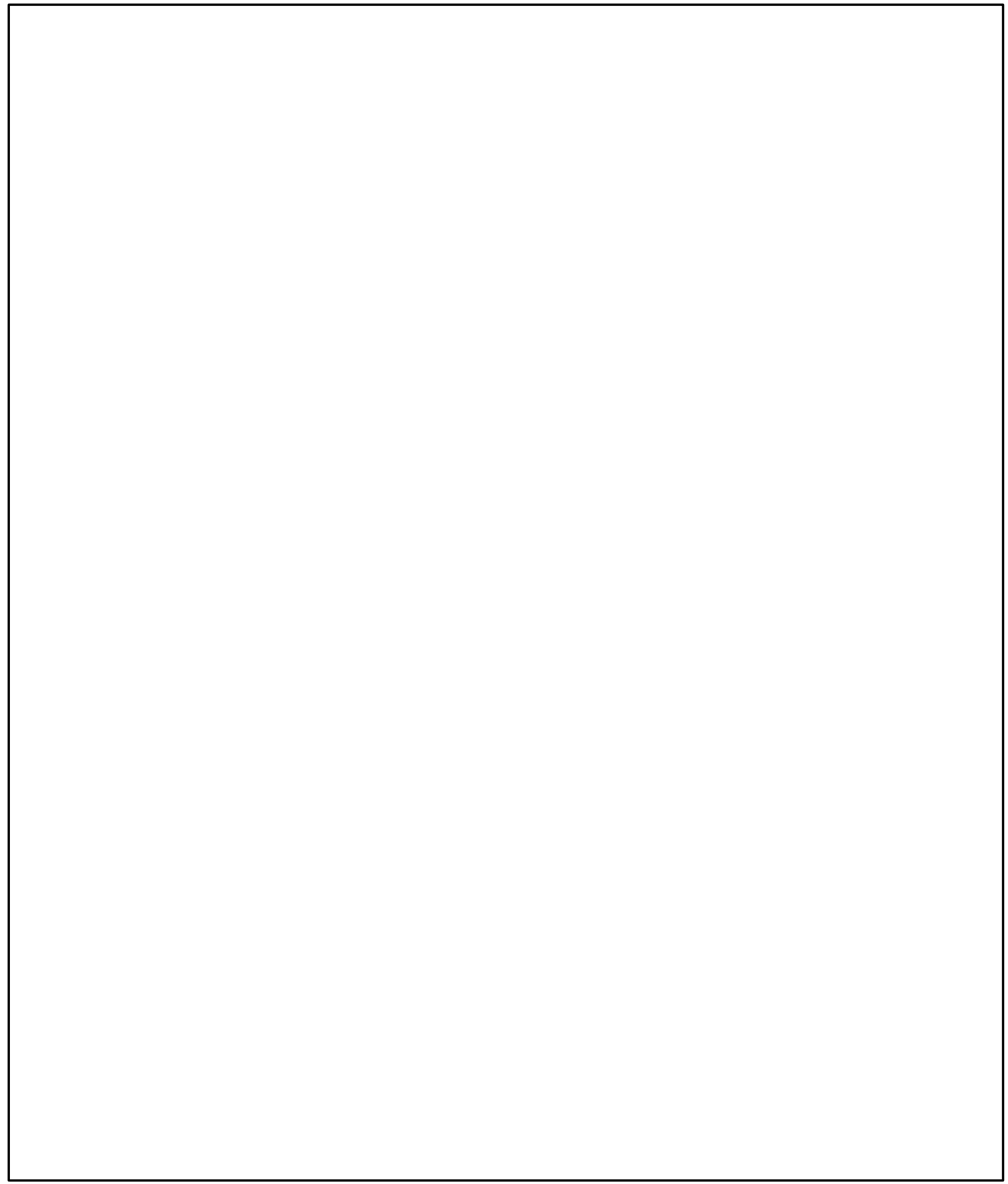

Figure 11: Attributed to Nicolas Lancret, La Chercheuse de Puces, c. 1720-1725. Oil on Panel, 29.7 x $25.5 \mathrm{~cm}$, The Wallace Collection, London. 


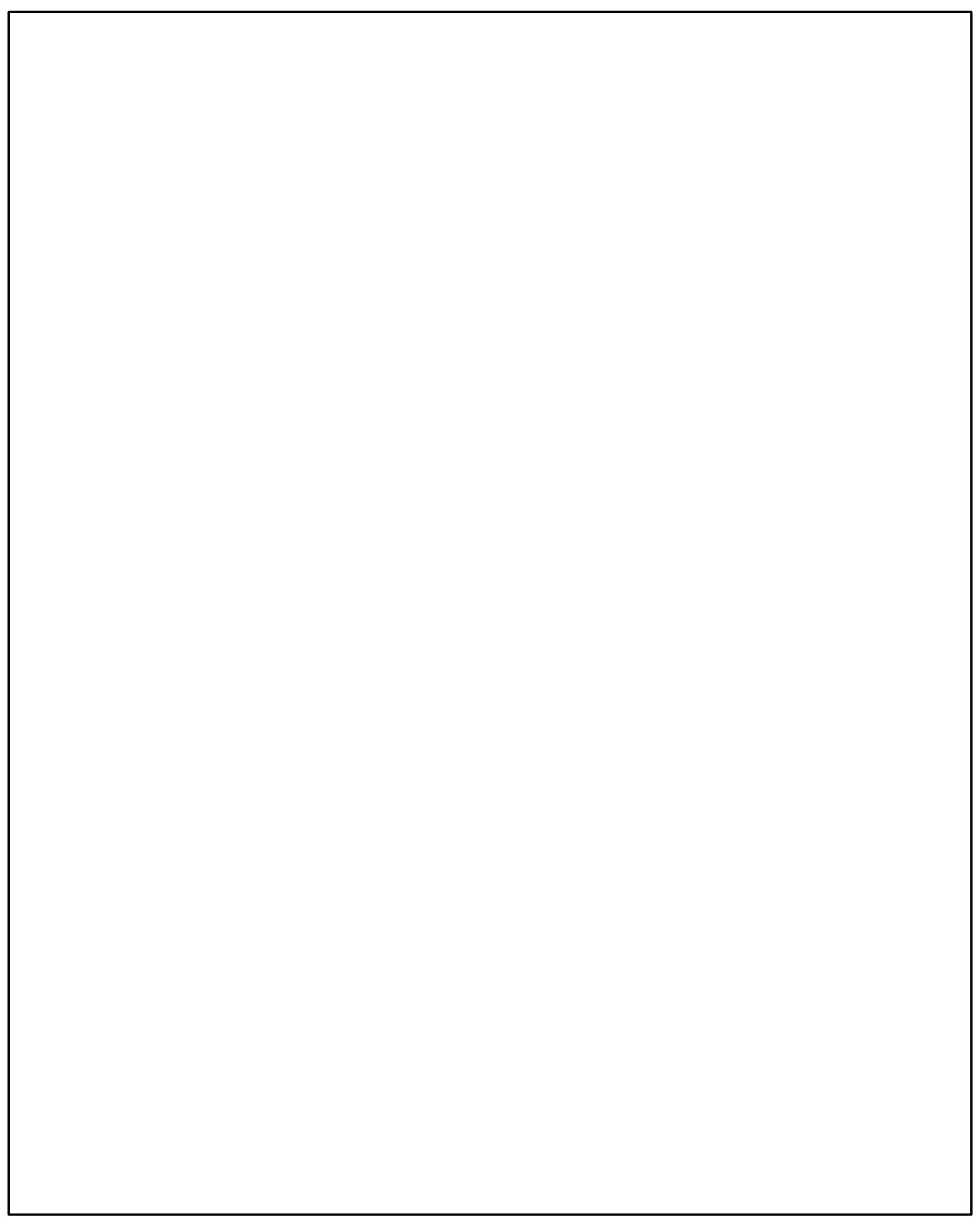

Figure 12: Nicolas Lancret, La Cuisine, c. 1720-1730. Oil on Canvas, 40 x $33 \mathrm{~cm}$, The Hermitage Museum, Saint Petersburg. 


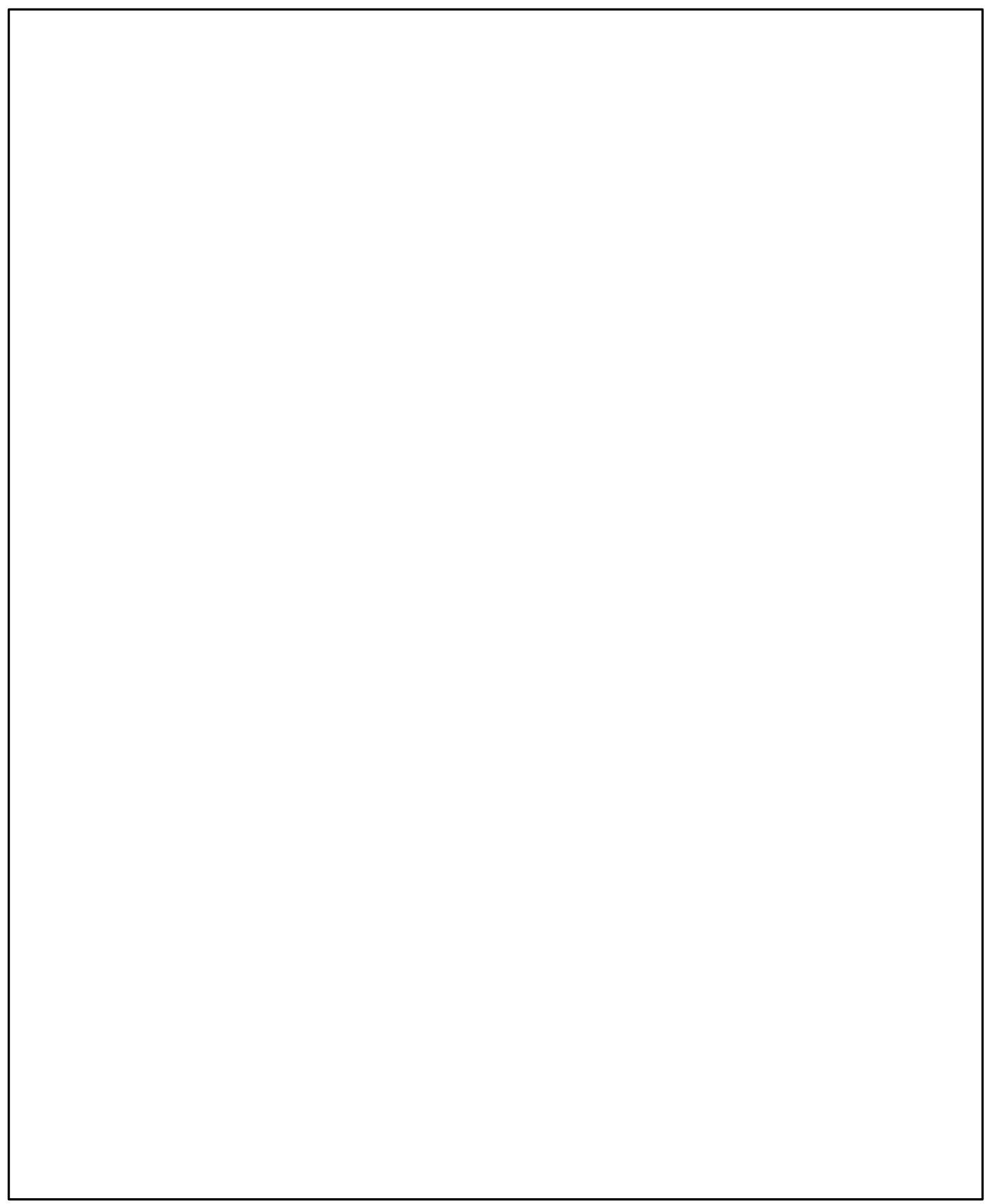

Figure 13: Willem Kalf with additions by Nicolas Lancret, Kitchen Interior, c. 1645 / c.1735. Oil on panel, 25.4 x $21 \mathrm{~cm}$, photograph before conservation. The Saint Louis Museum of Art, Saint Louis, Missouri. 


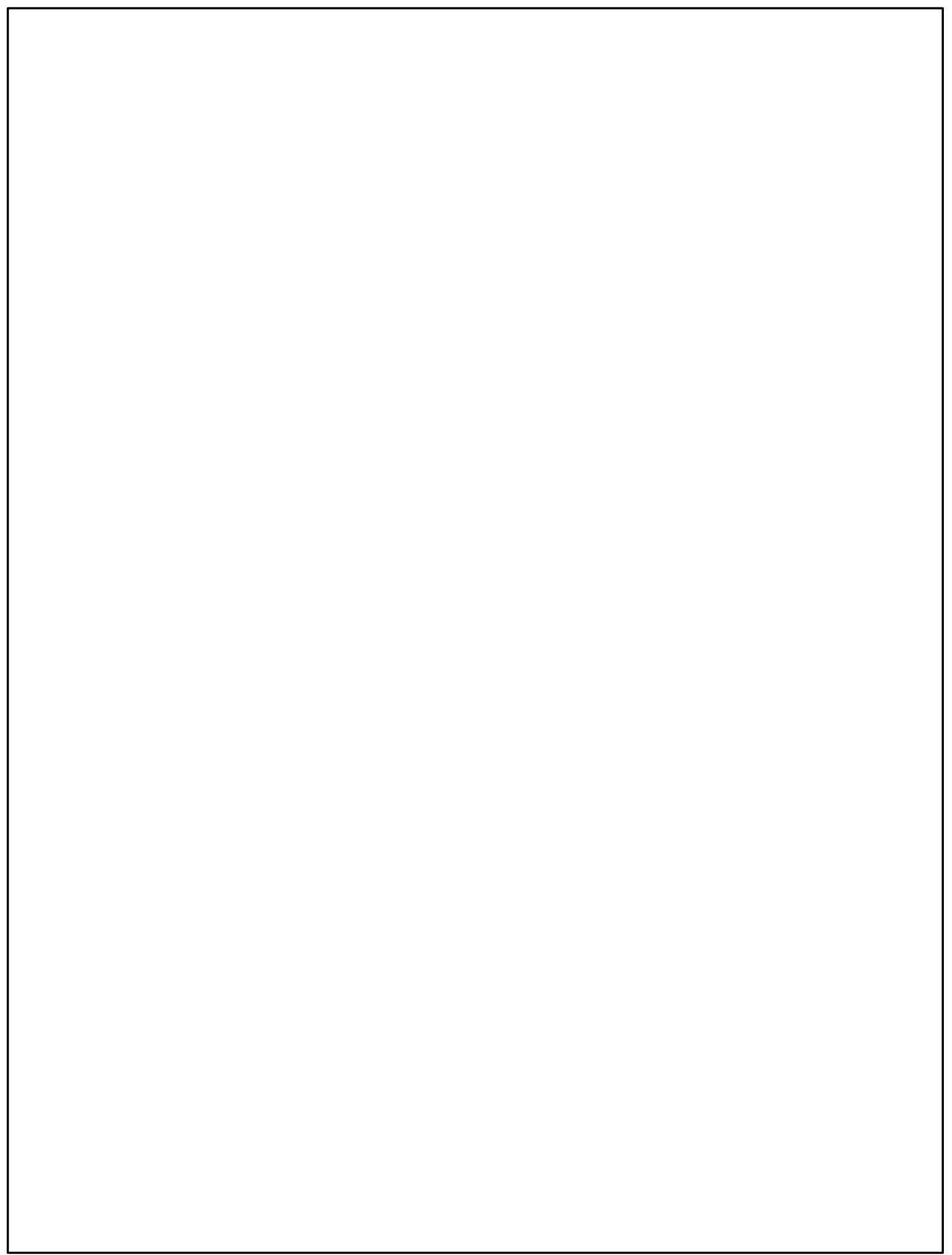

Figure 14: Nicolas Lancret, Le Nègre et La Cuisinière, c. 1720-1730. Location Unknown. 


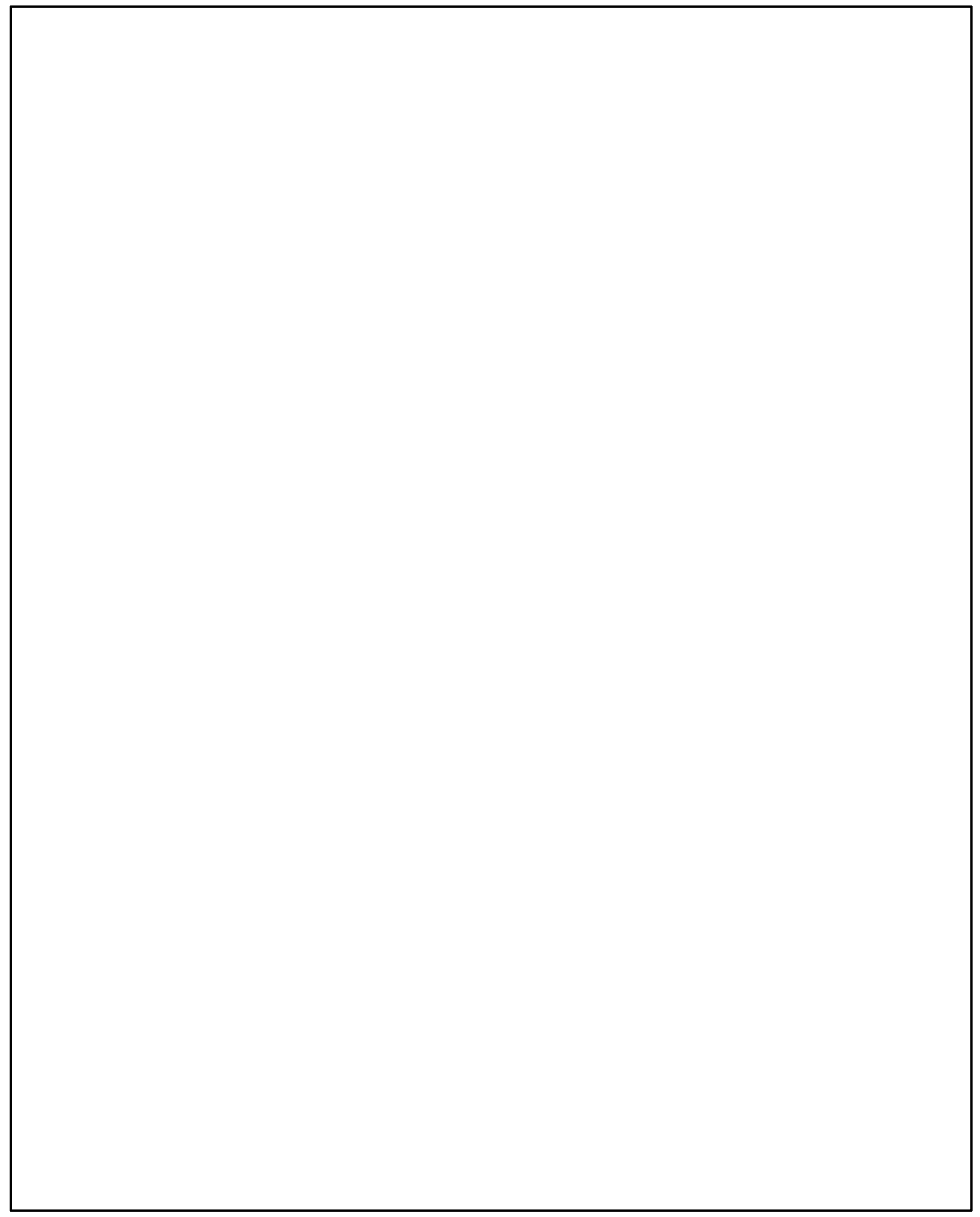

Figure 15: Nicolas Lancret, Le Galant Valet, c. 1720-1730. Oil on Canvas, 40 x $32.5 \mathrm{~cm}$, The Hermitage Museum, Saint Petersburg. 
Figure 16: Gerrit Dou, A Poulterer's Shop, ca. 1670. Oil on oak, 58 x $46 \mathrm{~cm}$, The National Gallery, London. 


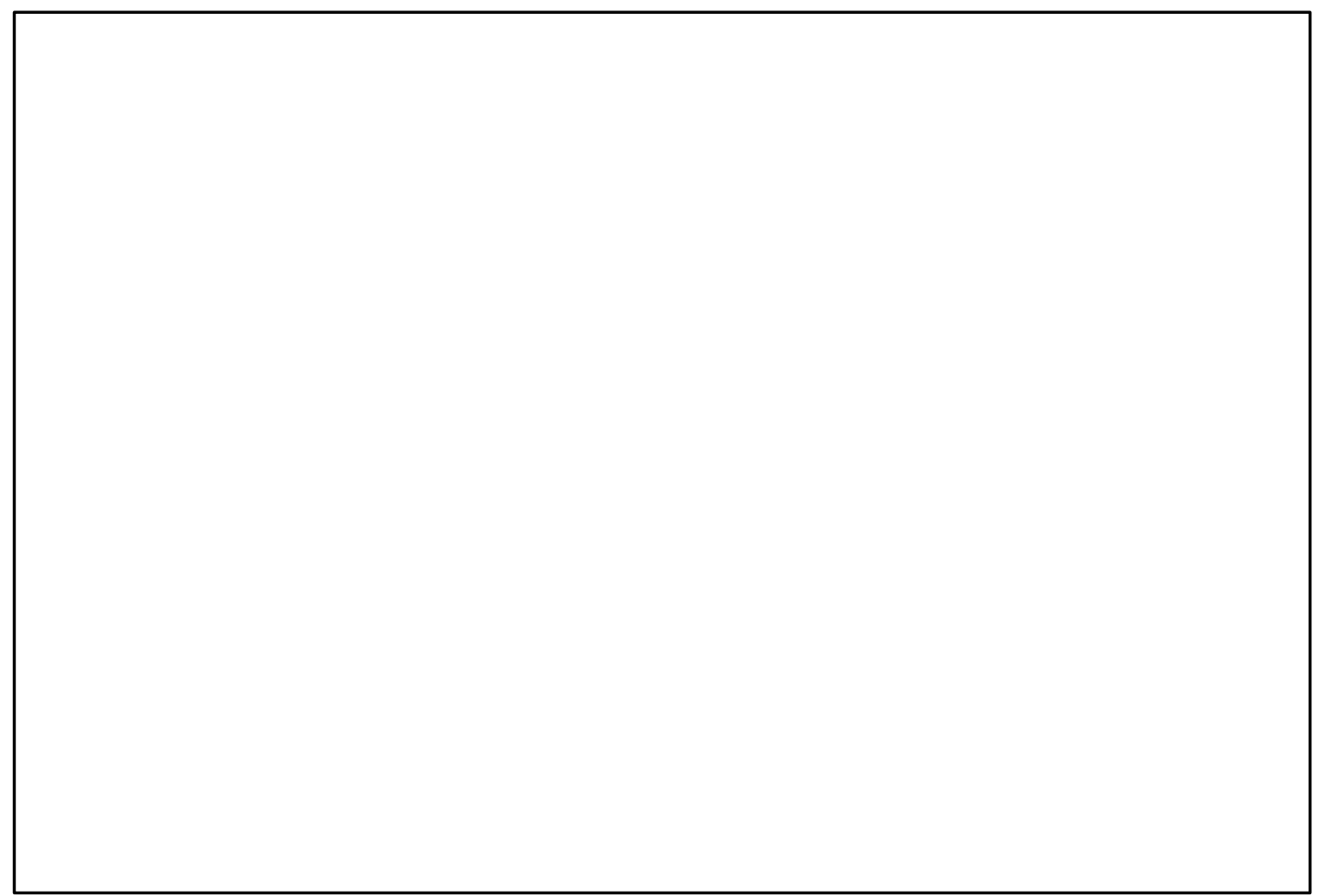

Figure 17: Joachim Beuckelaer, Market Scene, 1563. Oil on Oak, $111 \mathrm{~cm} \mathrm{x} 164 \mathrm{~cm}$, Residenzgalerie, Alte Residenz, Salzburg, Austria. 


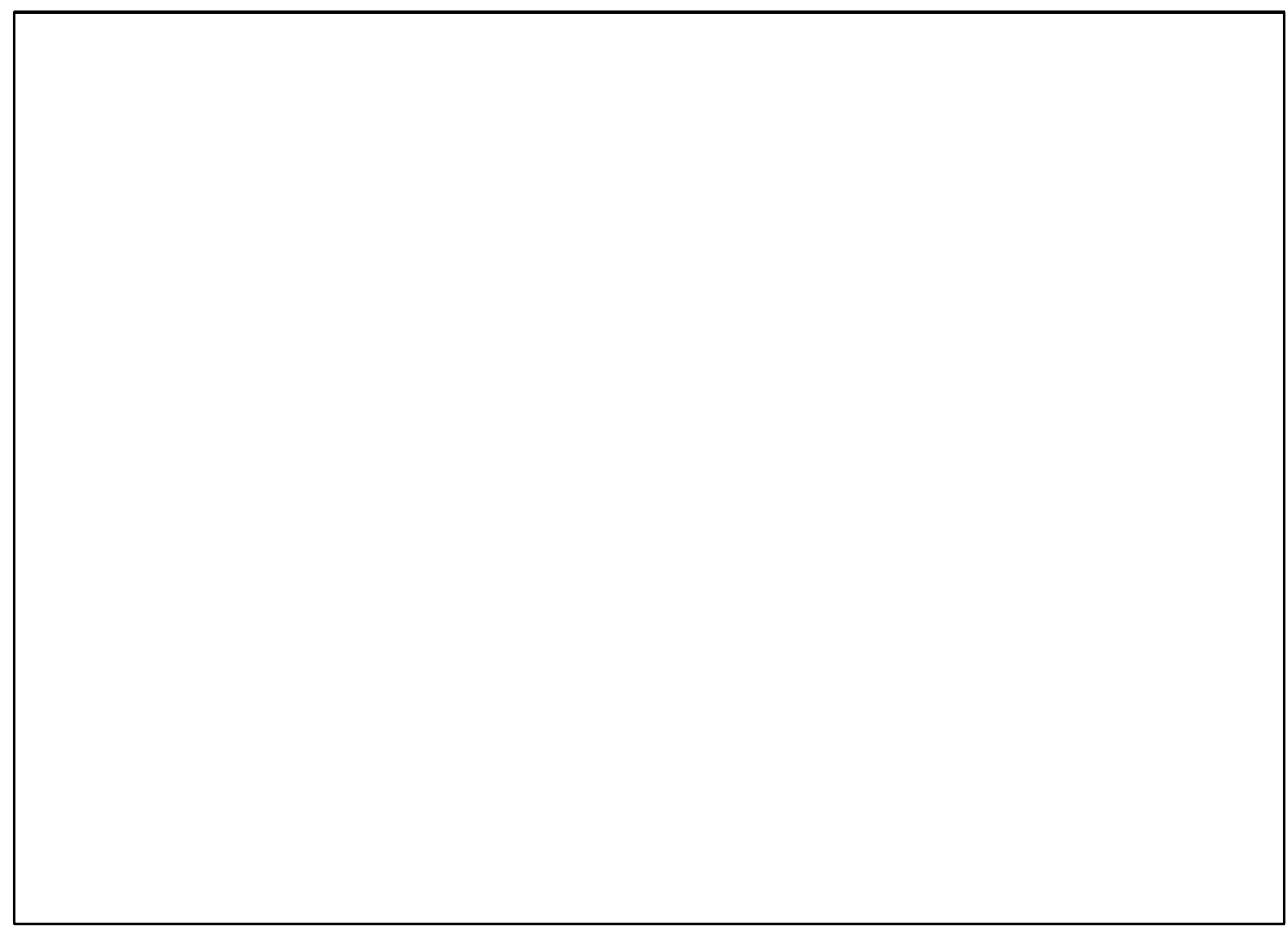

Figure 18: Antoine Watteau, Bivouac (Camp Volant), c.1710. Oil on canvas, 32.8 x 44.9 $\mathrm{cm}$, Pushkin Museum of Fine Arts, Moscow. 
Figure 19: Antoine Watteau, The Respite from War (Les délassements de la guerre), c. 1712. Oil on copperplate, 21.5 x $33.5 \mathrm{~cm}$, The Hermitage, Saint Petersburg. 


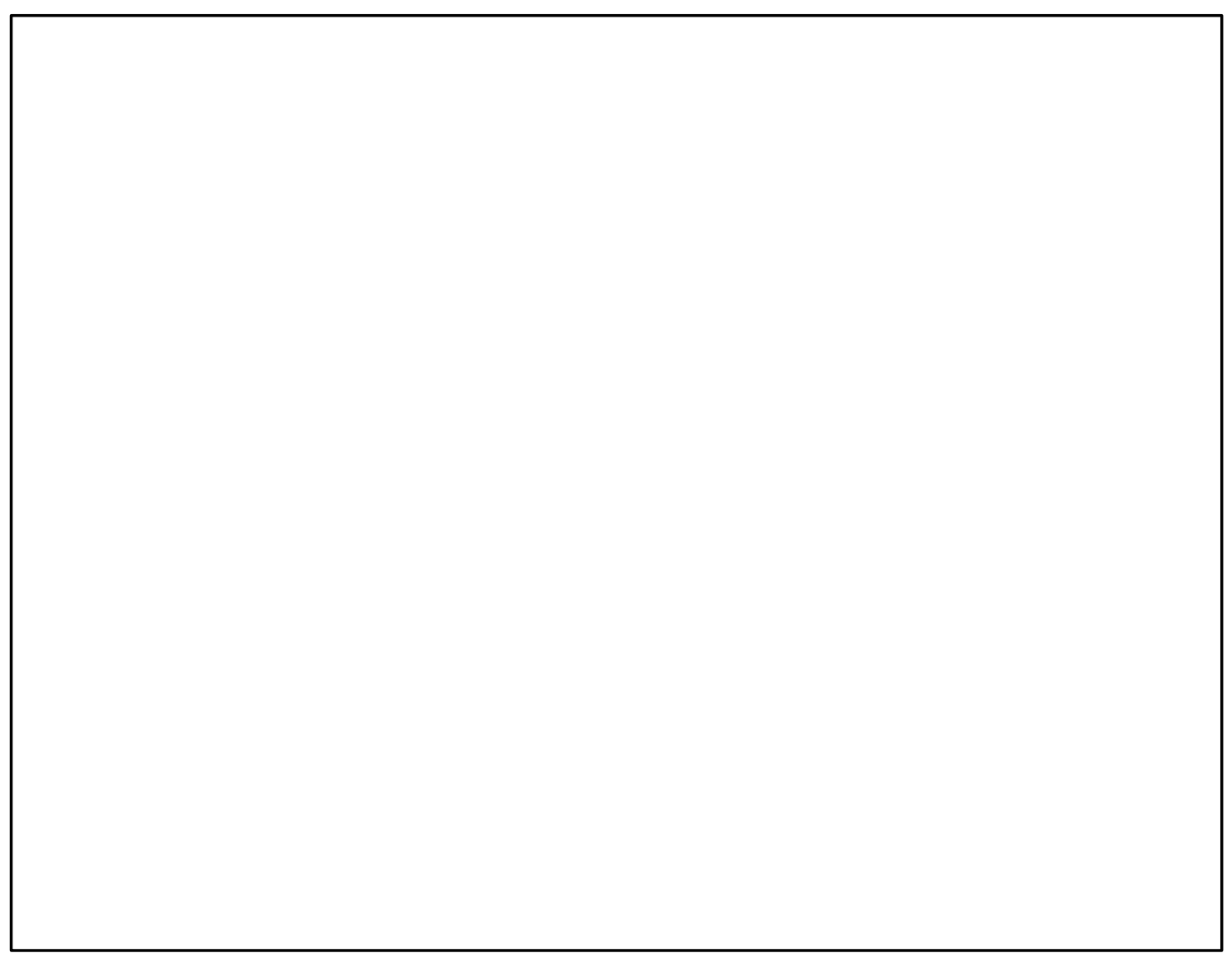

Figure 20: Engraving after Antoine Watteau, Départ de garnison (Depart of the Garrison). Original, 42.7 x $56.2 \mathrm{~cm}$, The Victoria and Albert Museum, London. 


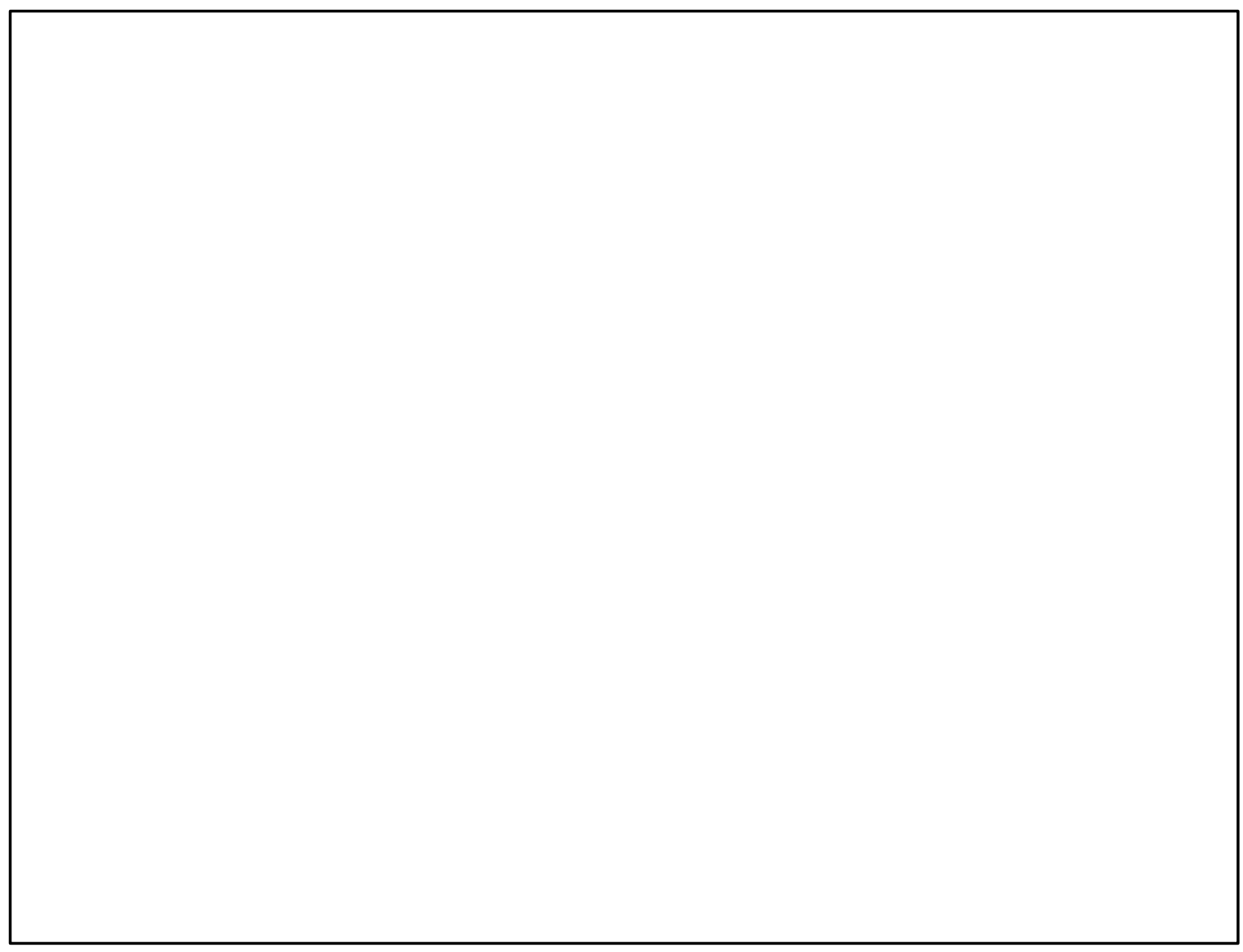

Figure 21: Nicolas Lancret, Military Camp. Private Collection of Mary Tavener Holmes. 
Figure 22: Nicolas Lancret, Fête in a Wood, c. 1722. Oil on Canvas, 60 x $79.2 \mathrm{~cm}$, The Wallace Collection, London. 


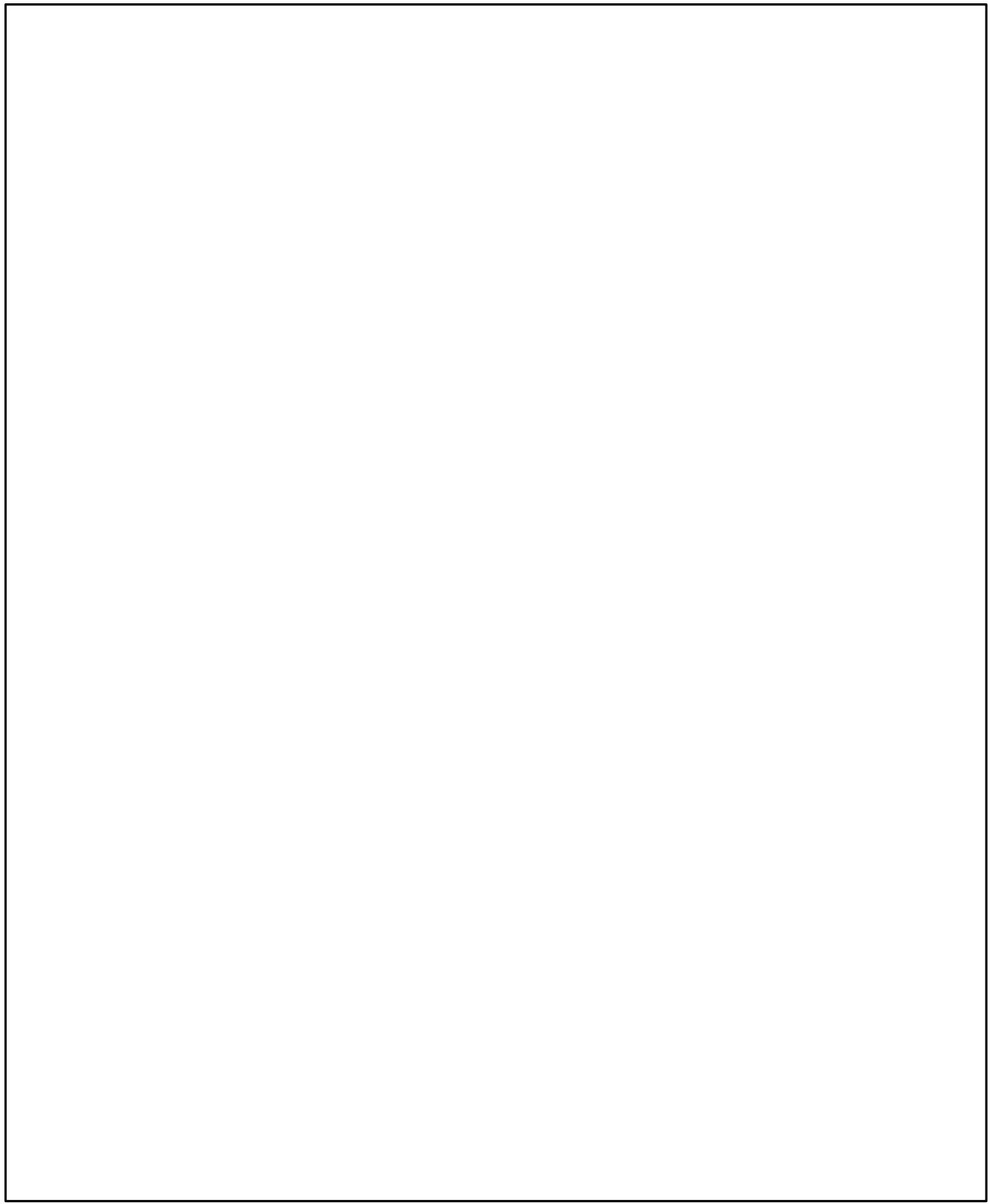

Figure 23: Nicolas Lancret, L'automne (Autumn), 1721-23. Oil on canvas, 113 x $94 \mathrm{~cm}$, Previously of the Homeland Foundation, Inc., Armenia, New York. 


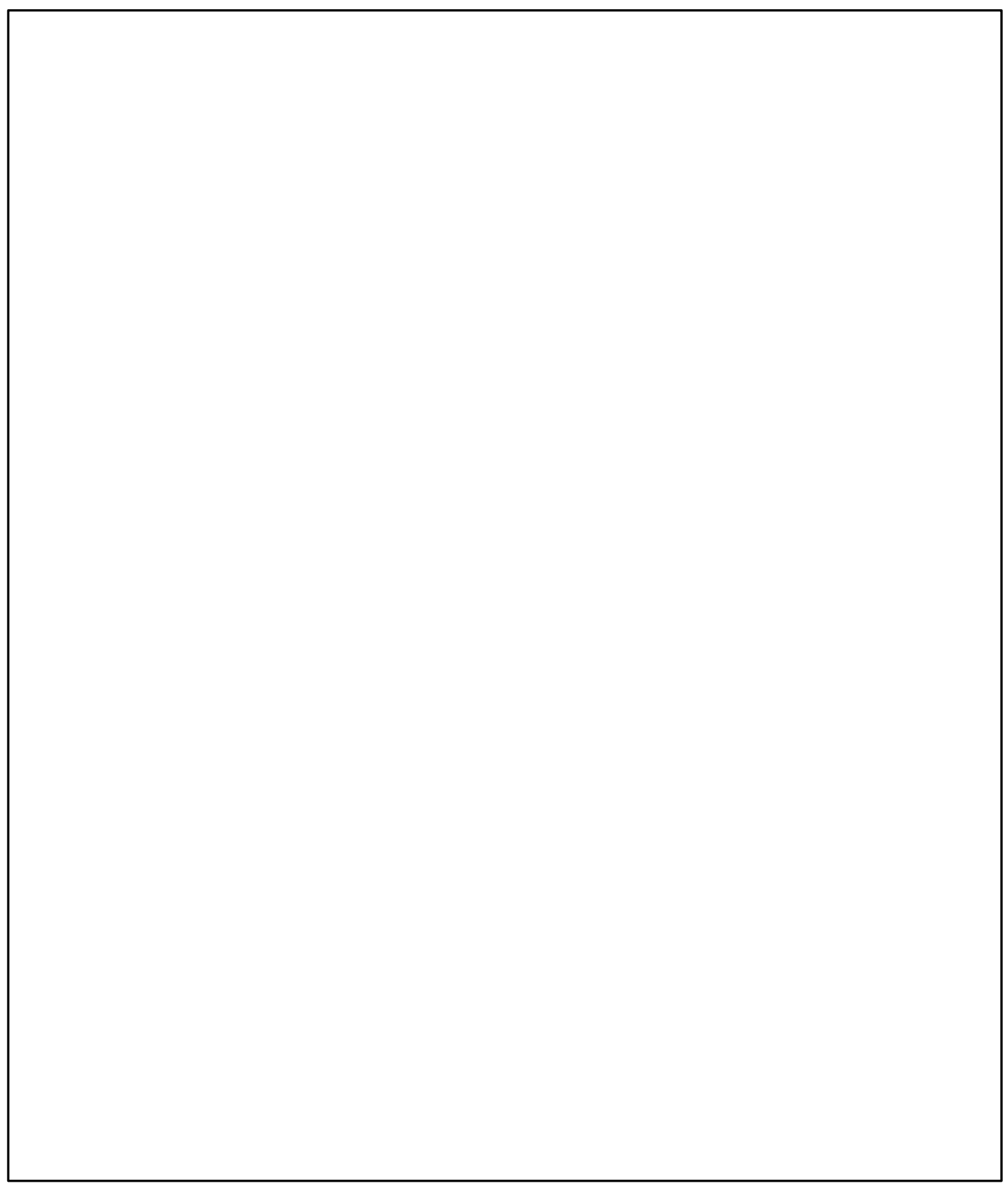

Figure 24: Antoine Watteau, Les fêtes vénitiennes, 1718-19. Oil on canvas, 55.9 x 45.7 $\mathrm{cm}$, National Gallery of Scotland, Edinburgh. 


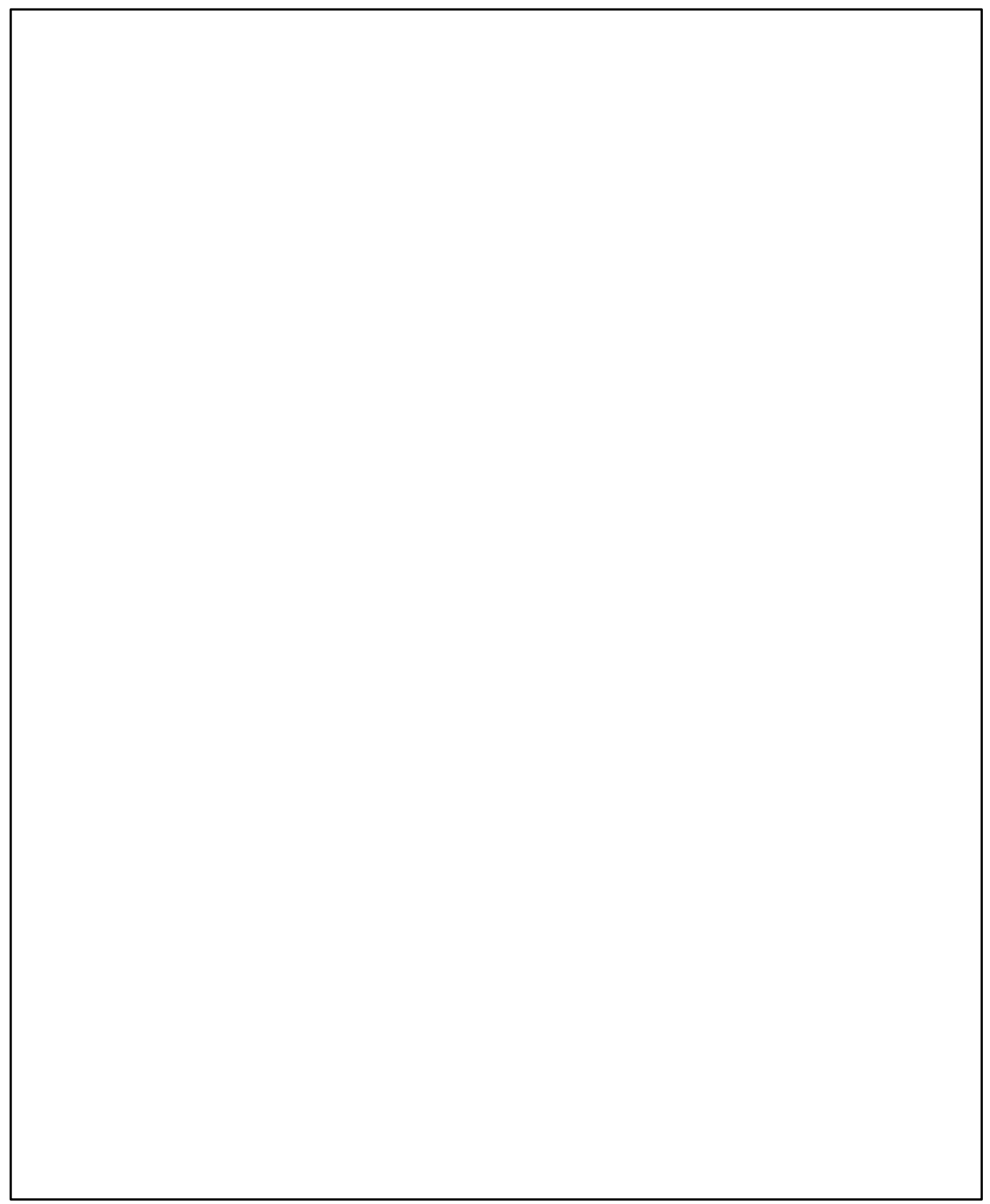

Figure 25: Antoine Watteau, Le Printemps, 1717/1718. Oil on Canvas, 119 x $98 \mathrm{~cm}$, Destroyed, formerly Collection of Lady Sybil Grant. 


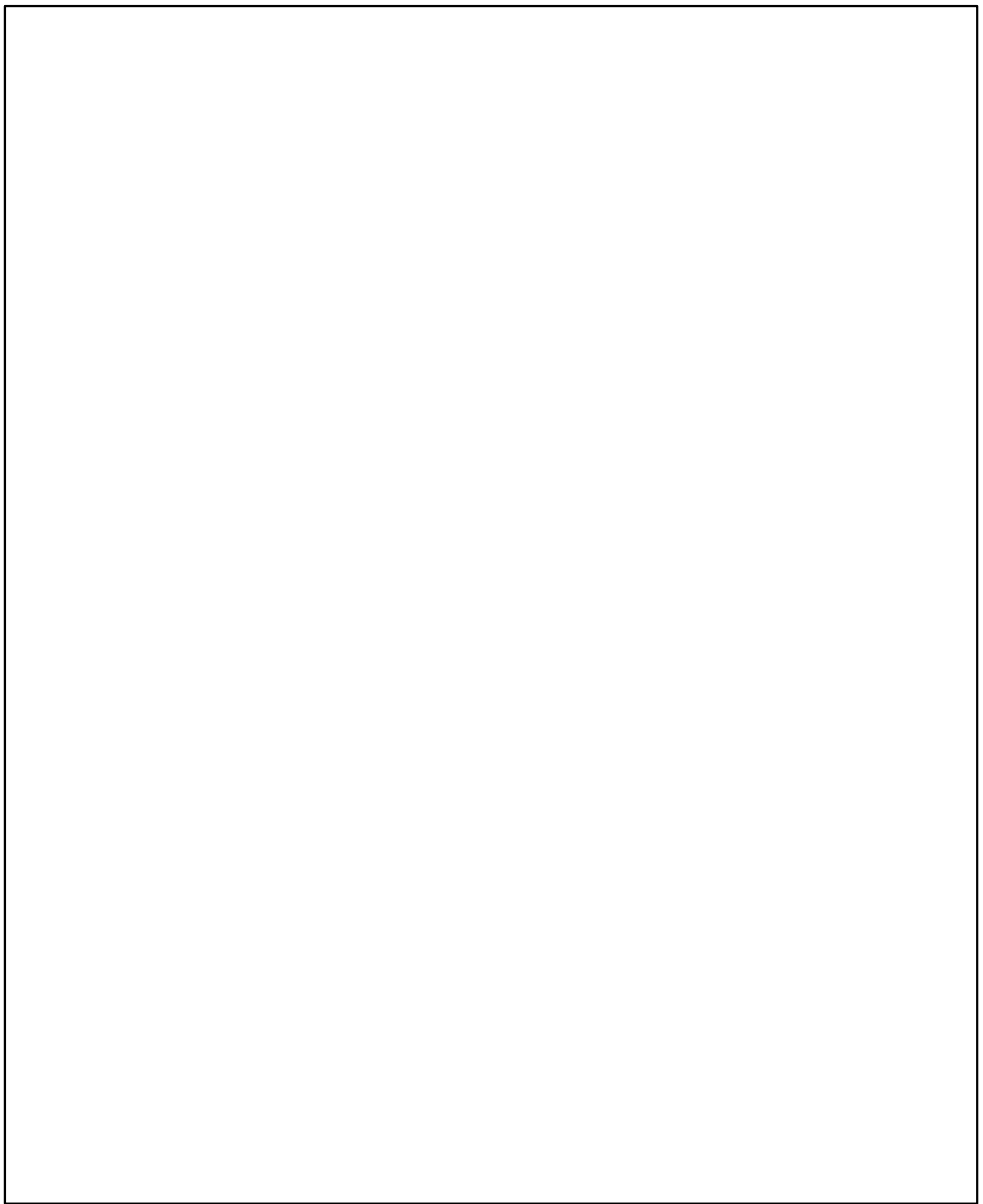

Figure 26: Louis Desplaces, Engraving after Antoine Watteau, Le Printemps. L'oeuvre d'Antoine Watteau (volume I), c. 1740, National Gallery of Art, Washington, Widener Collection, 1942.9.2092. 
Figure 27: Antoine Watteau, L'Été, 1717/1718. Oil on Canvas, 141.6 x $115.7 \mathrm{~cm}$, National Gallery of Art, Washington D.C., Samuel H. Kress Collection. 


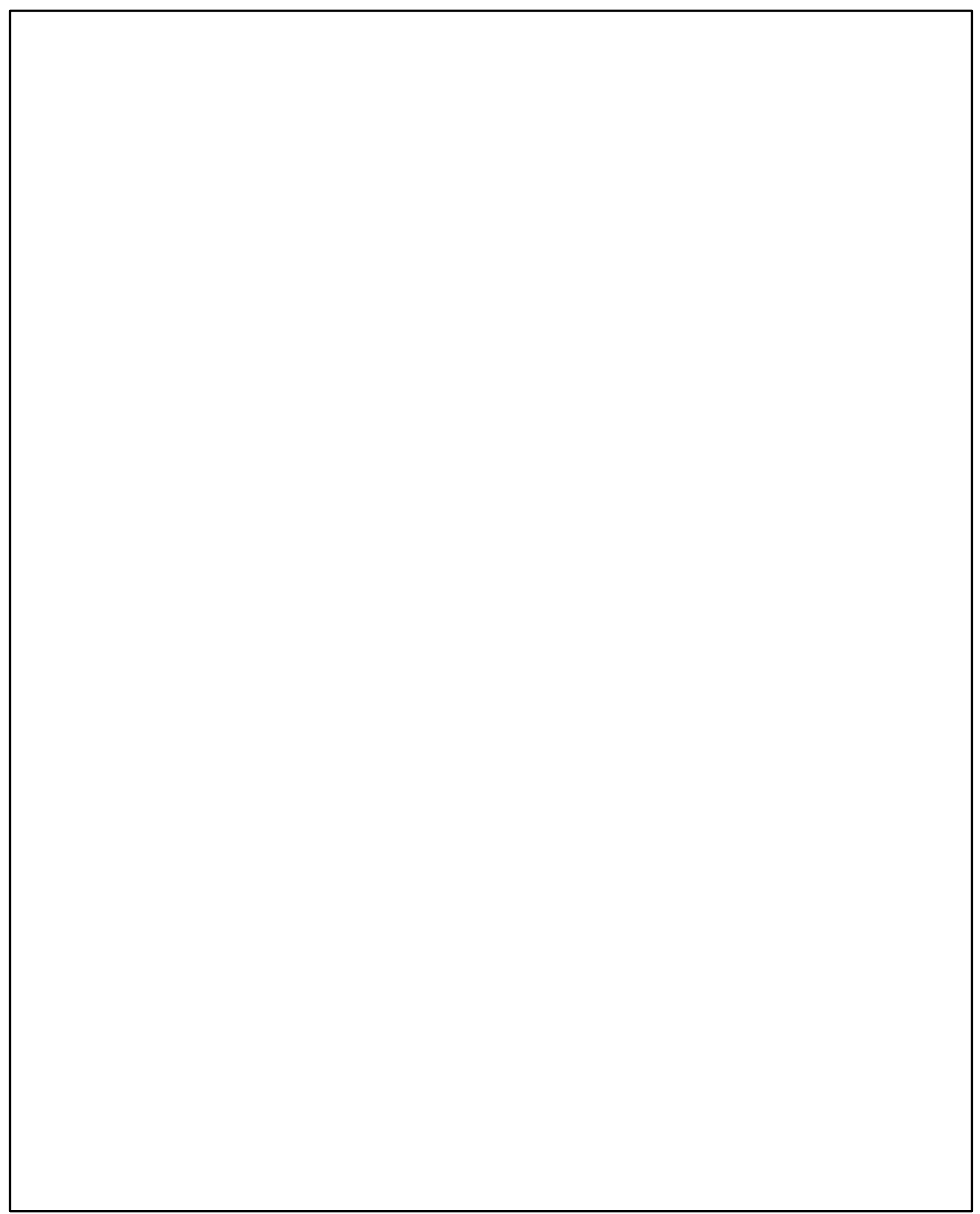

Figure 28: Etienne Fessard, Engraving after Antoine Watteau, L'Automne. L'oeuvre d'Antoine Watteau (volume I), c. 1740, National Gallery of Art, Washington, Widener Collection, 1942.9.2092. 


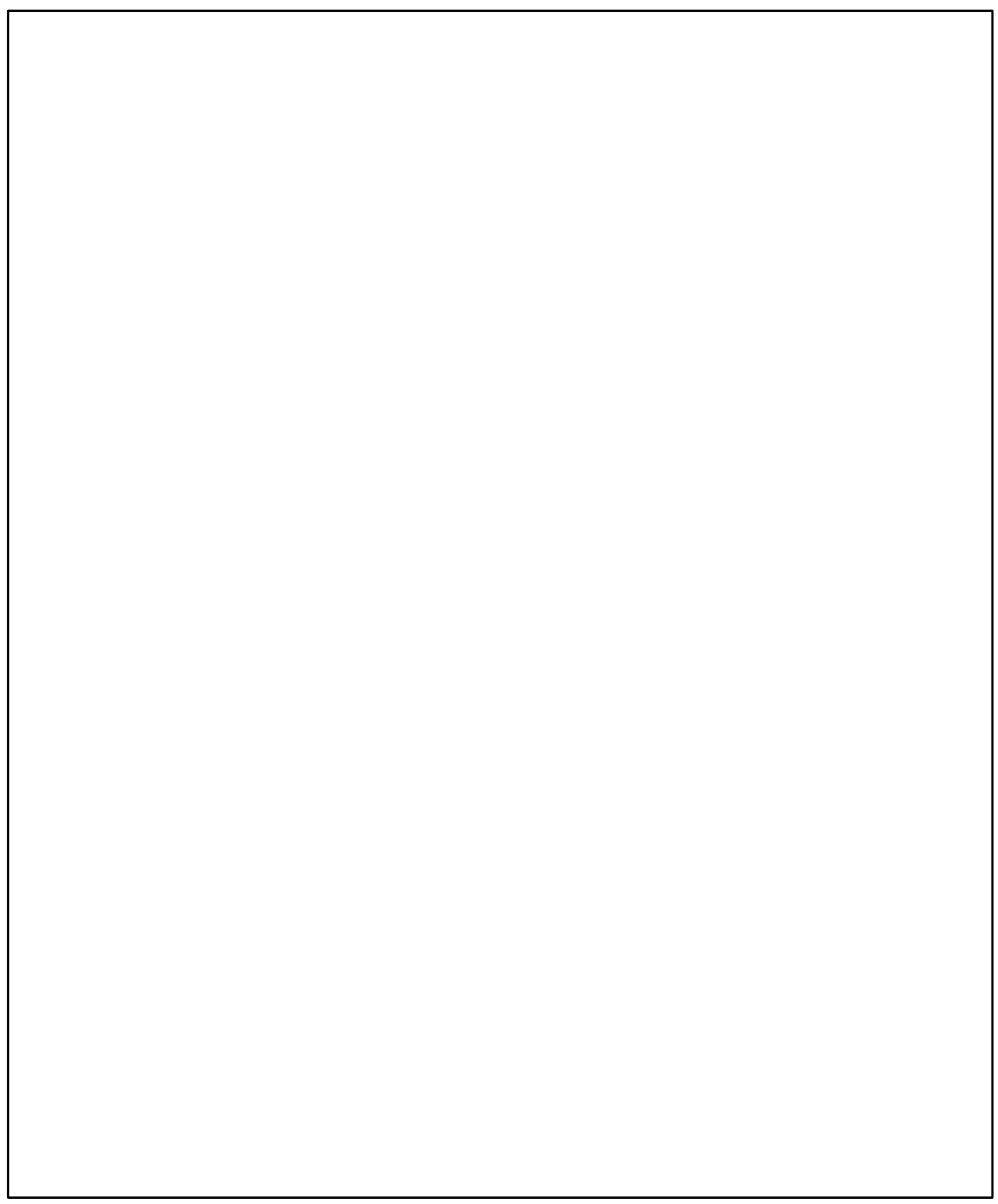

Figure 29: Antoine Watteau, sketch for L'Automne, 1713-1718. Oil on Canvas, 48 x 40.5 cm, Musée du Louvre, Paris. 


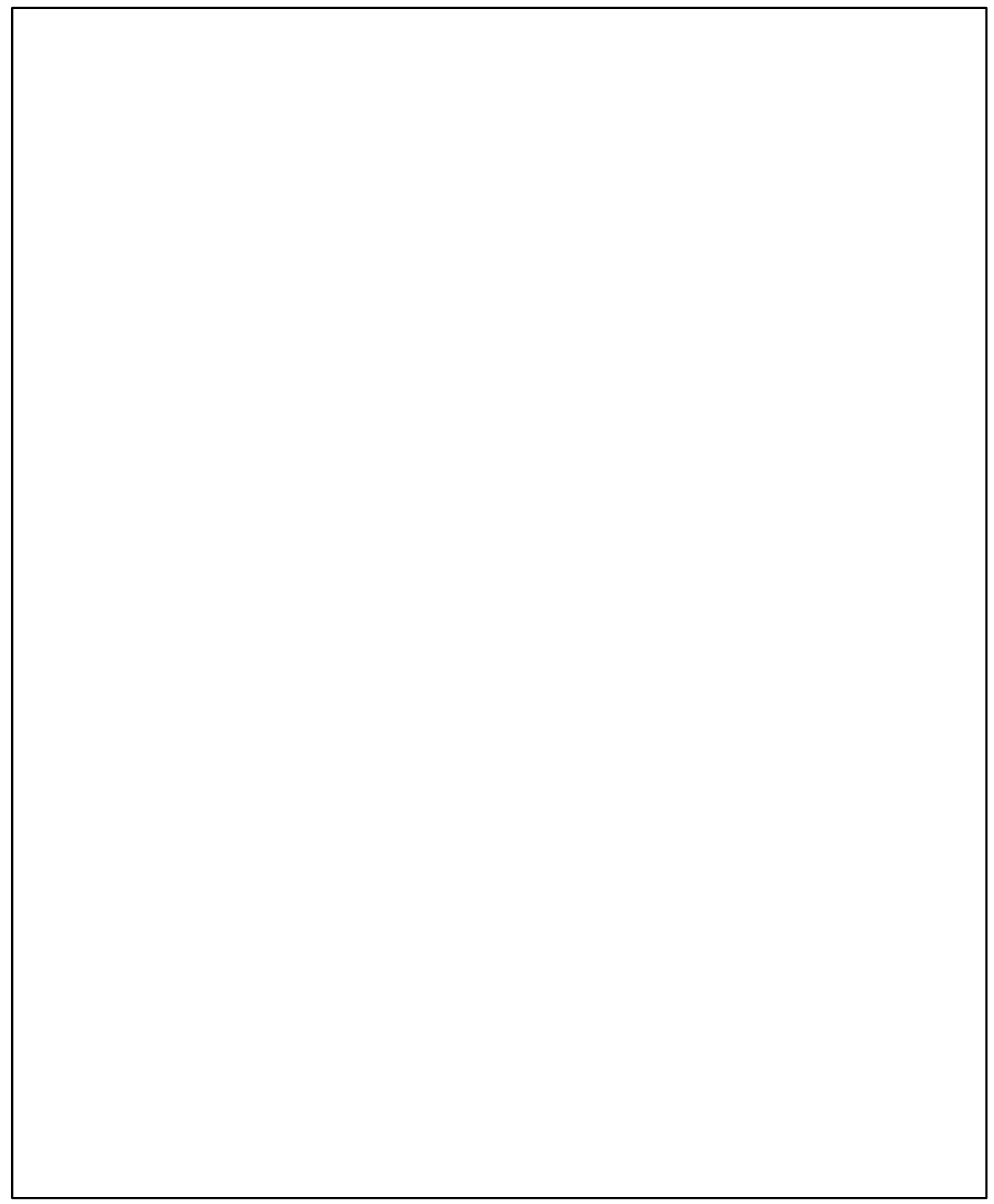

Figure 30: Jean Audran, Engraving after Antoine Watteau, Winter. L'oeuvre d'Antoine Watteau (volume I), c. 1740, engraving, National Gallery of Art, Washington, Widener Collection, 1942.9.2092. 


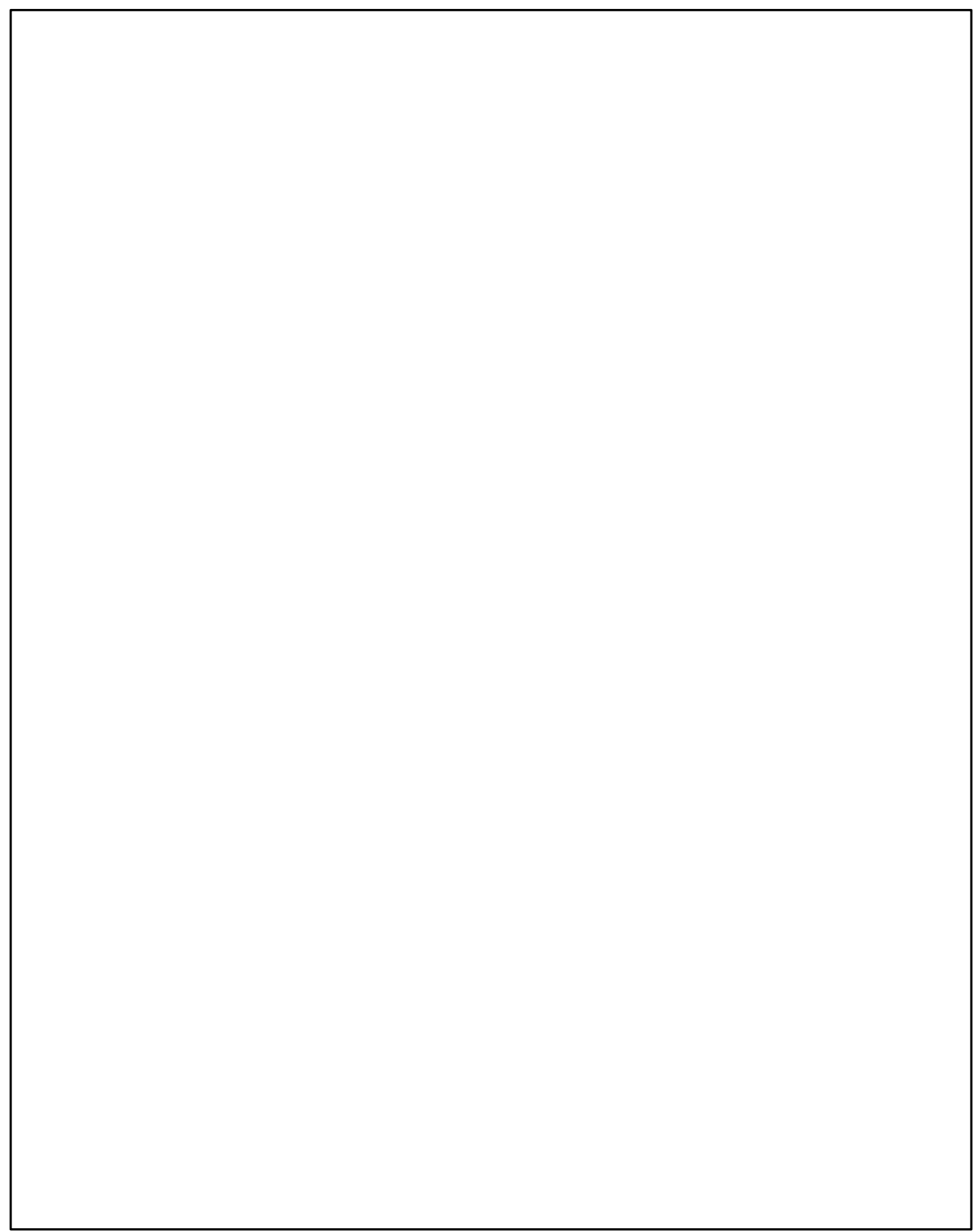

Figure 31: Engraving after Antoine Watteau, Le Lorgneur, 34.2 × $26.9 \mathrm{~cm}$. London, Trustees of the British Museum. 
Figure 32: Antoine Watteau, L'amour au théâtre françois (Love in the French Theatre), c. 1712. Oil on Canvas, 37 x 48 cm, Gemäldegalerie, Staatliche Museen zu Berlin Preußischer Kulturbes. 
Figure 33: Gabriel Huquier after Antoine Watteau, L'Automne, Collection iconographique Maciet, série "Graveurs et ornemanistes, XVIe-XVIIIe siècle," album Watteau I, (Paris : Chez Huquier, 1734), Bibliothèque des Arts décoratifs, Maciet ORN/14/19-22. 


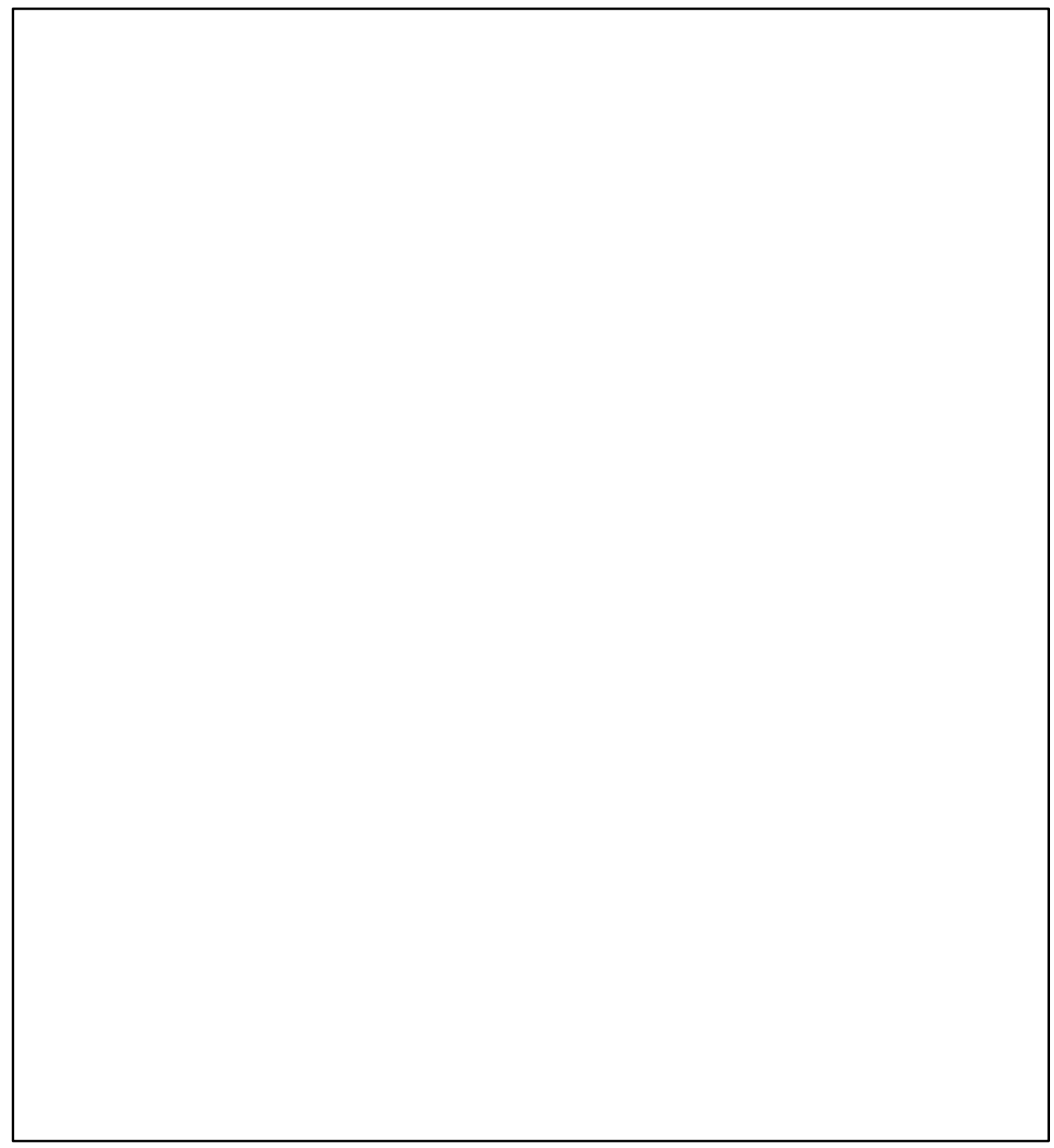

Figure 34: Gabriel Huquier after Antoine Watteau, detail of L'Automne. Collection iconographique Maciet, série "Graveurs et ornemanistes, XVIe-XVIIIe siècle," album Watteau I (Paris : chez la Ve de F. Chereau, 1729), Bibliothèque des Arts décoratifs, Maciet ORN/14/23-24. 


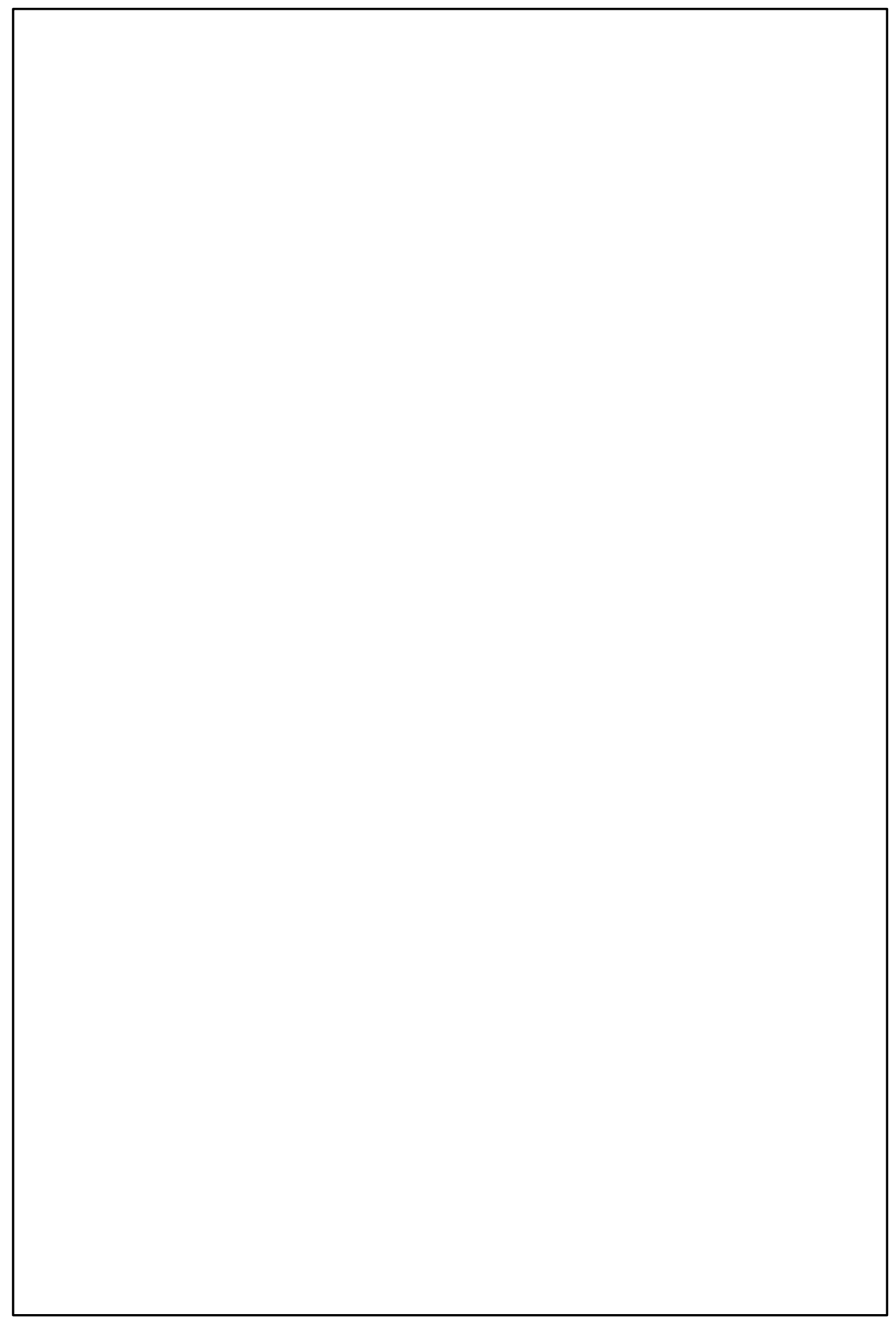

Figure 35: Antoine Watteau, L'Automne. Red chalk, 290 x $185 \mathrm{~cm}$, The Hermitage Museum, Saint Petersburg. 


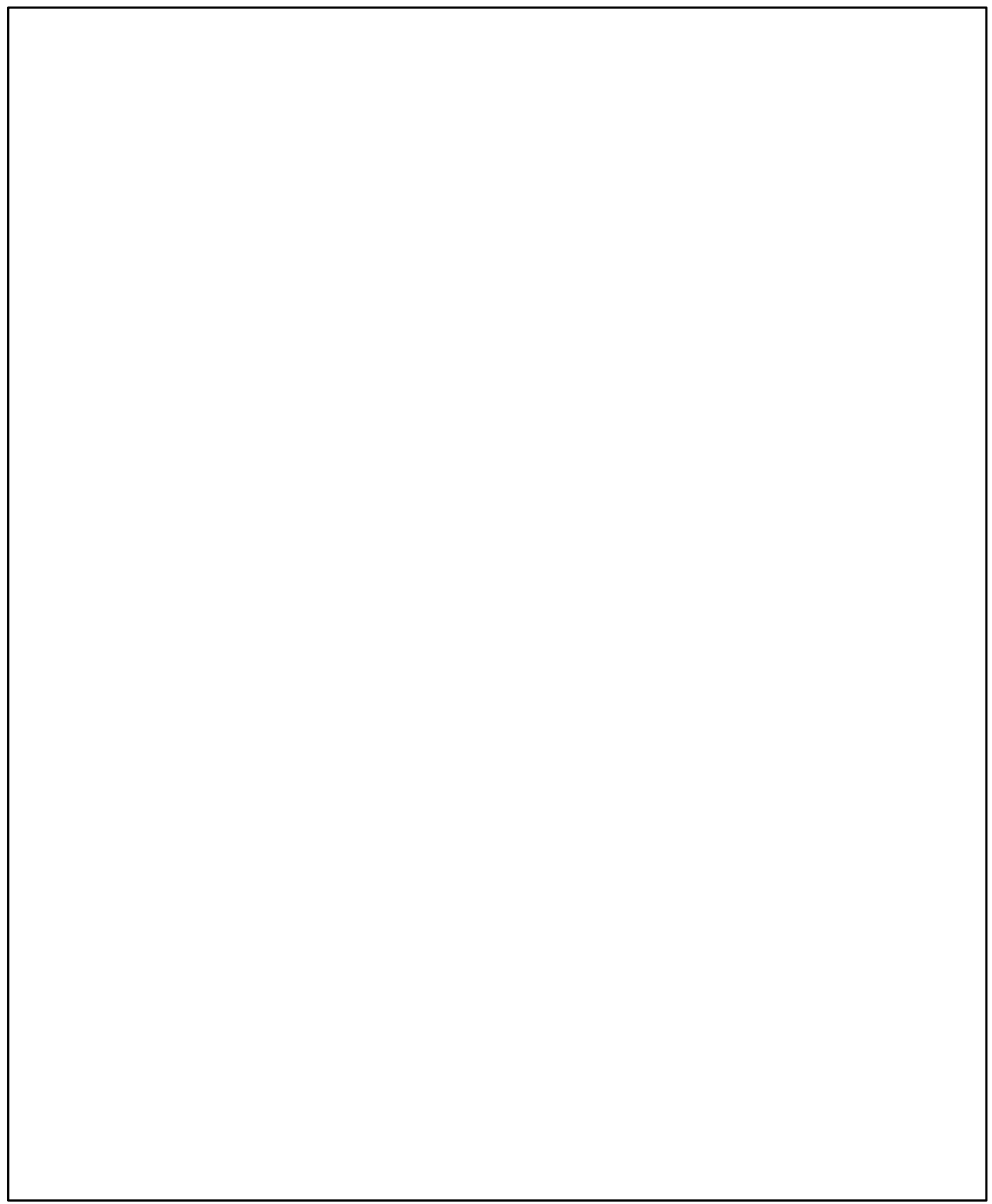

Figure 36: Nicolas Lancret, Spring, 1721-23. Oil on Canvas, 115.9 x $95 \mathrm{~cm}$, The Hermitage Museum, Saint Petersburgh. 


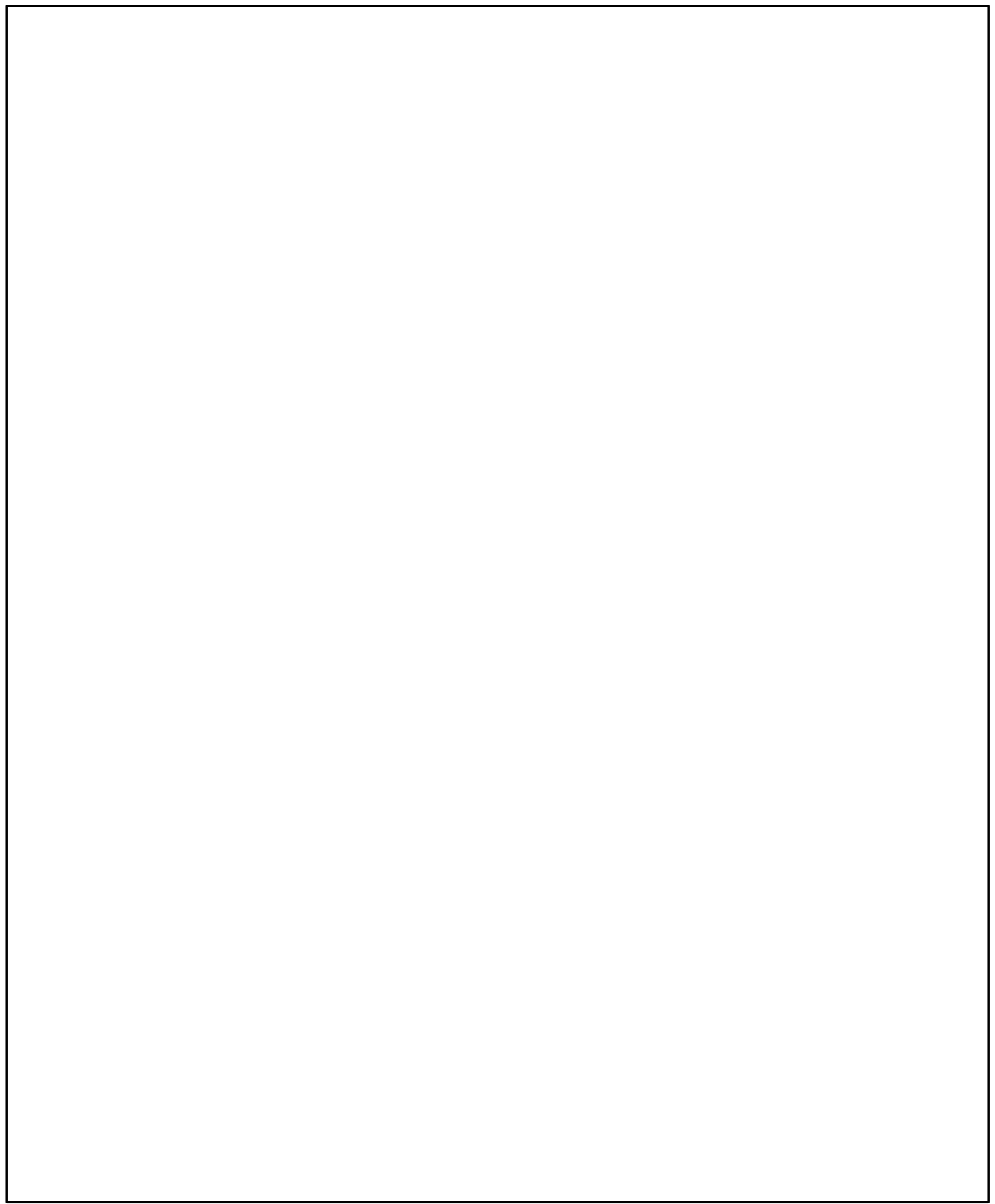

Figure 37: Nicolas Lancret, Summer, 1721-23. Oil on Canvas, 115 x $95 \mathrm{~cm}$, The Hermitage Museum, Saint Petersburgh. 
Figure 38: Nicolas Lancret, Winter, 1721-23. Oil on Canvas, 115 x $94 \mathrm{~cm}$, Private Collection. 


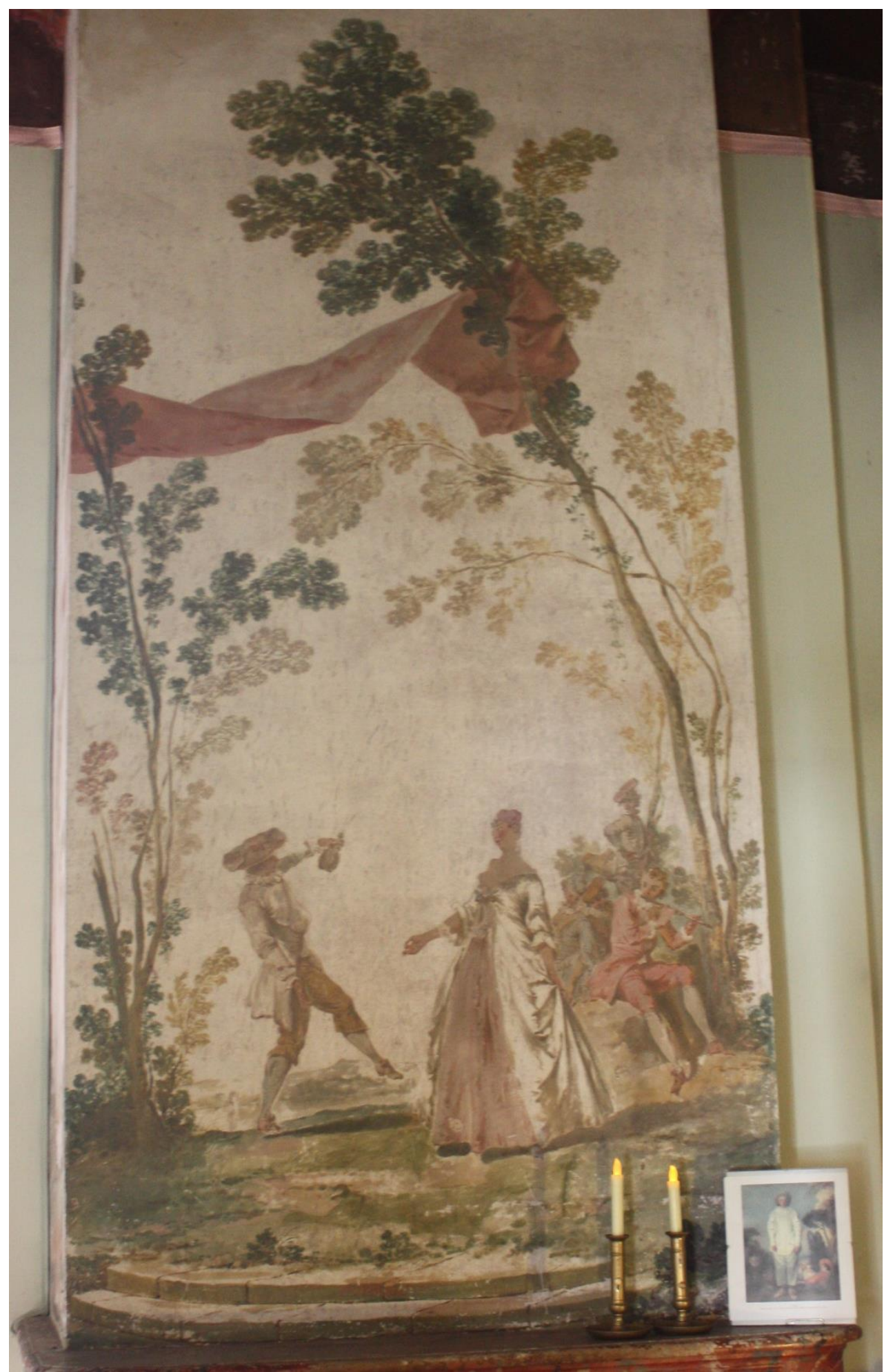

Figure 39: Attributed to Antoine Watteau, Fêtes Galantes d'Automne. Château de Condé en Brie. Image courtesy of the author. 


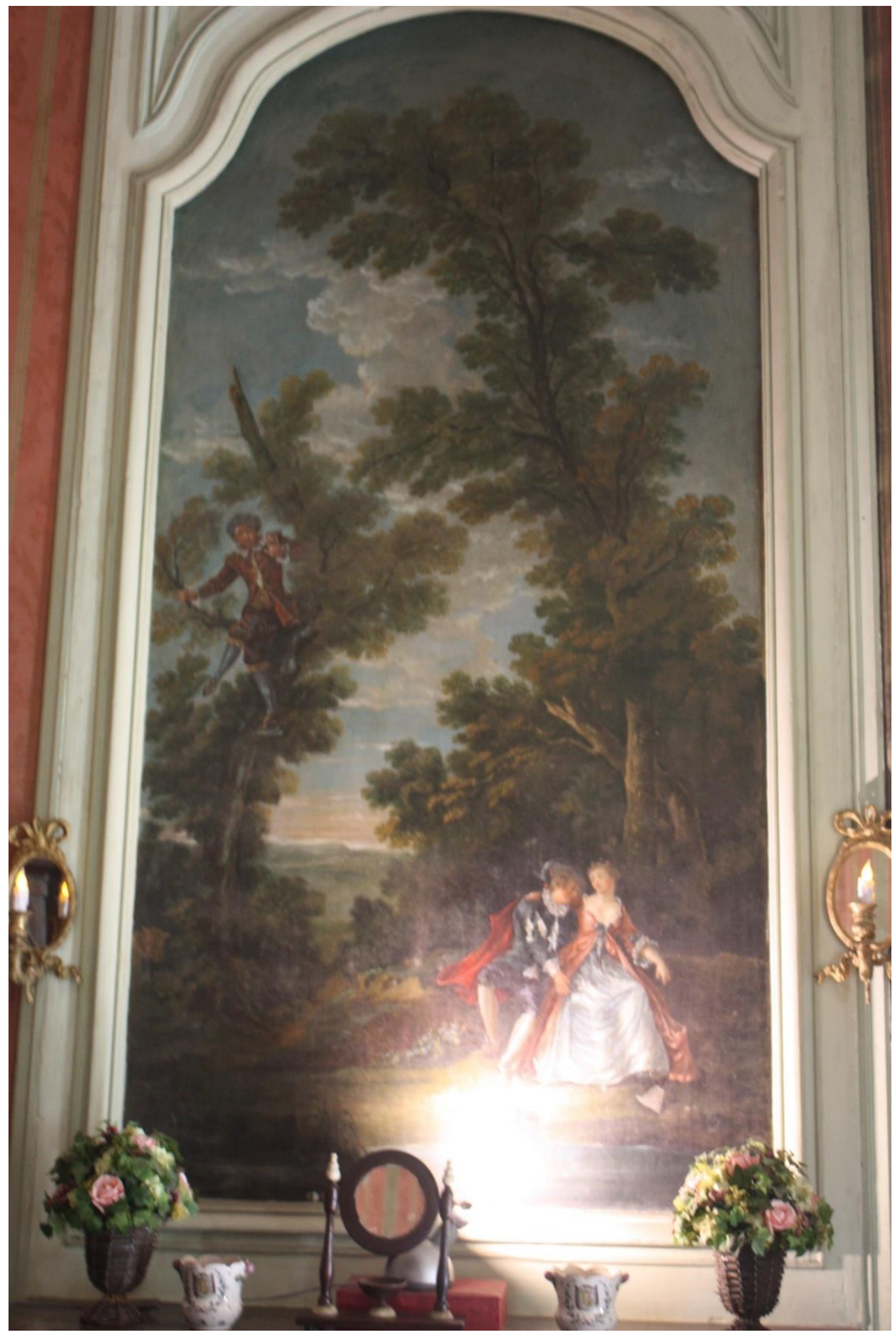

Figure 40: Attributed to Nicolas Lancret, Le villageois ayant perdu son veau from Jean de La Fontaine's fables. Château de Condé en Brie. Image courtesy of the author. 


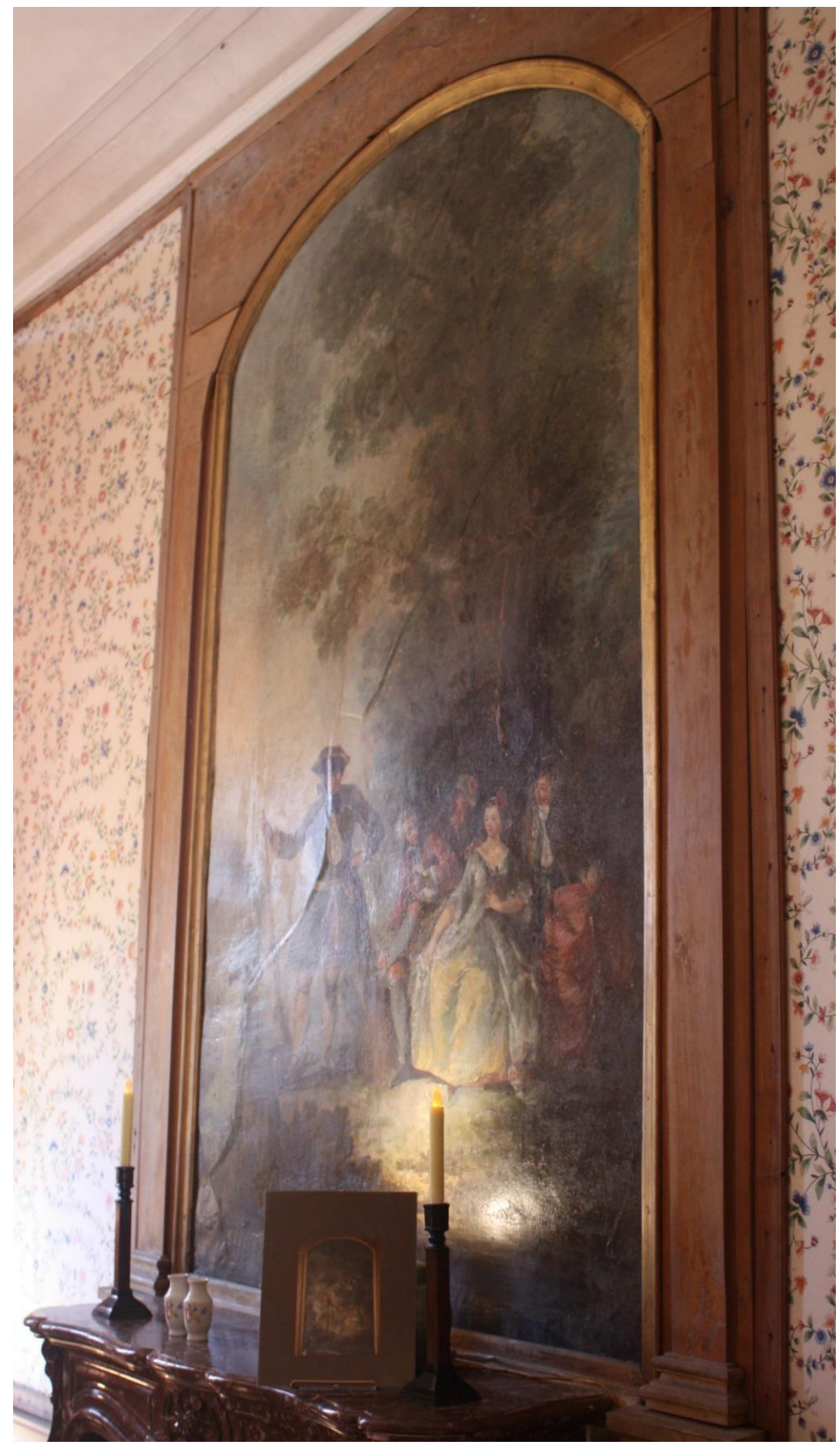

Figure 41: Attributed to Antoine Watteau, A hunting party. Château de Condé en Brie. Image courtesy of the author. 


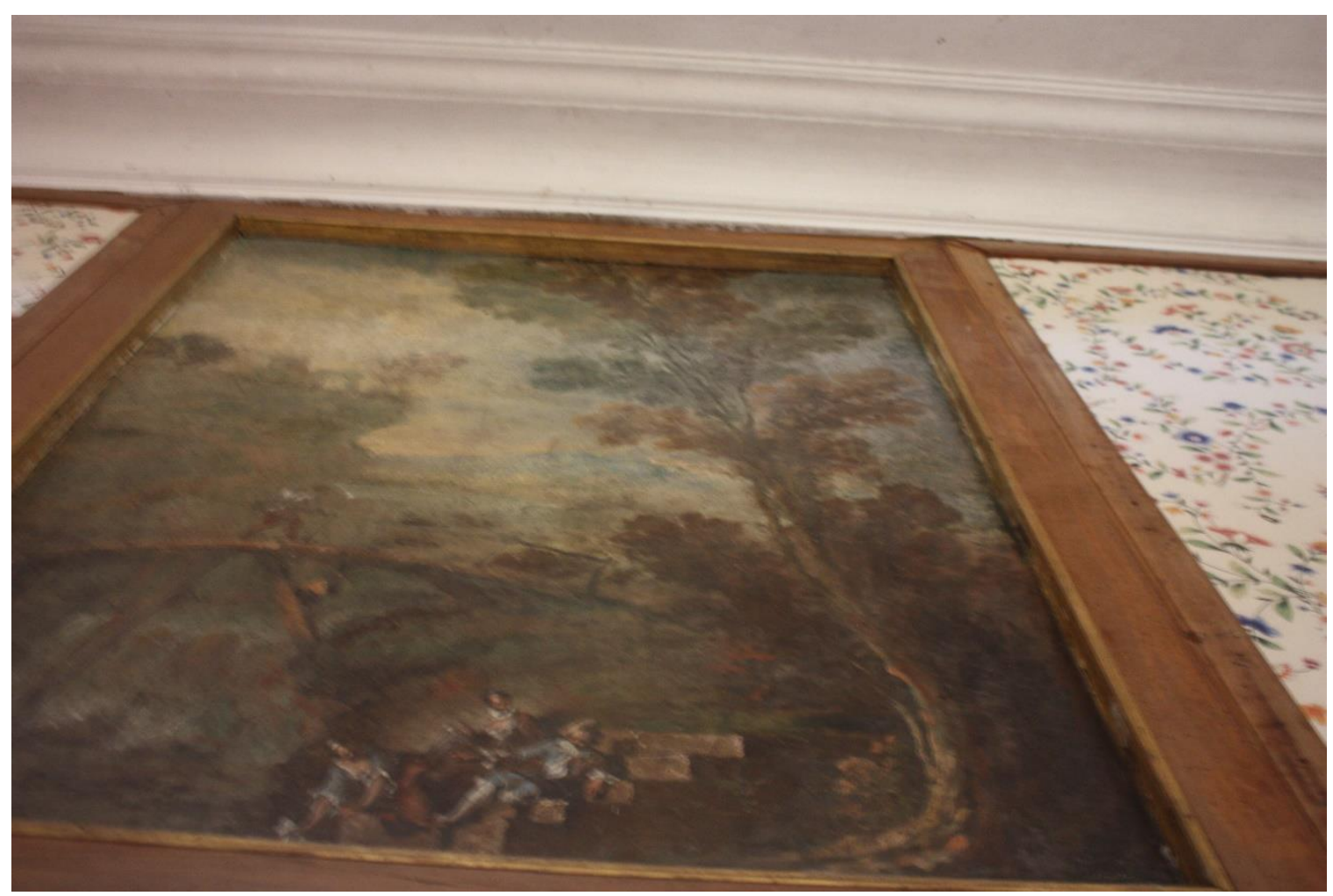

Figure 42: Attributed to Nicolas Lancret, Figures in a landscape. Château de Condé en Brie. Image courtesy of the author. 


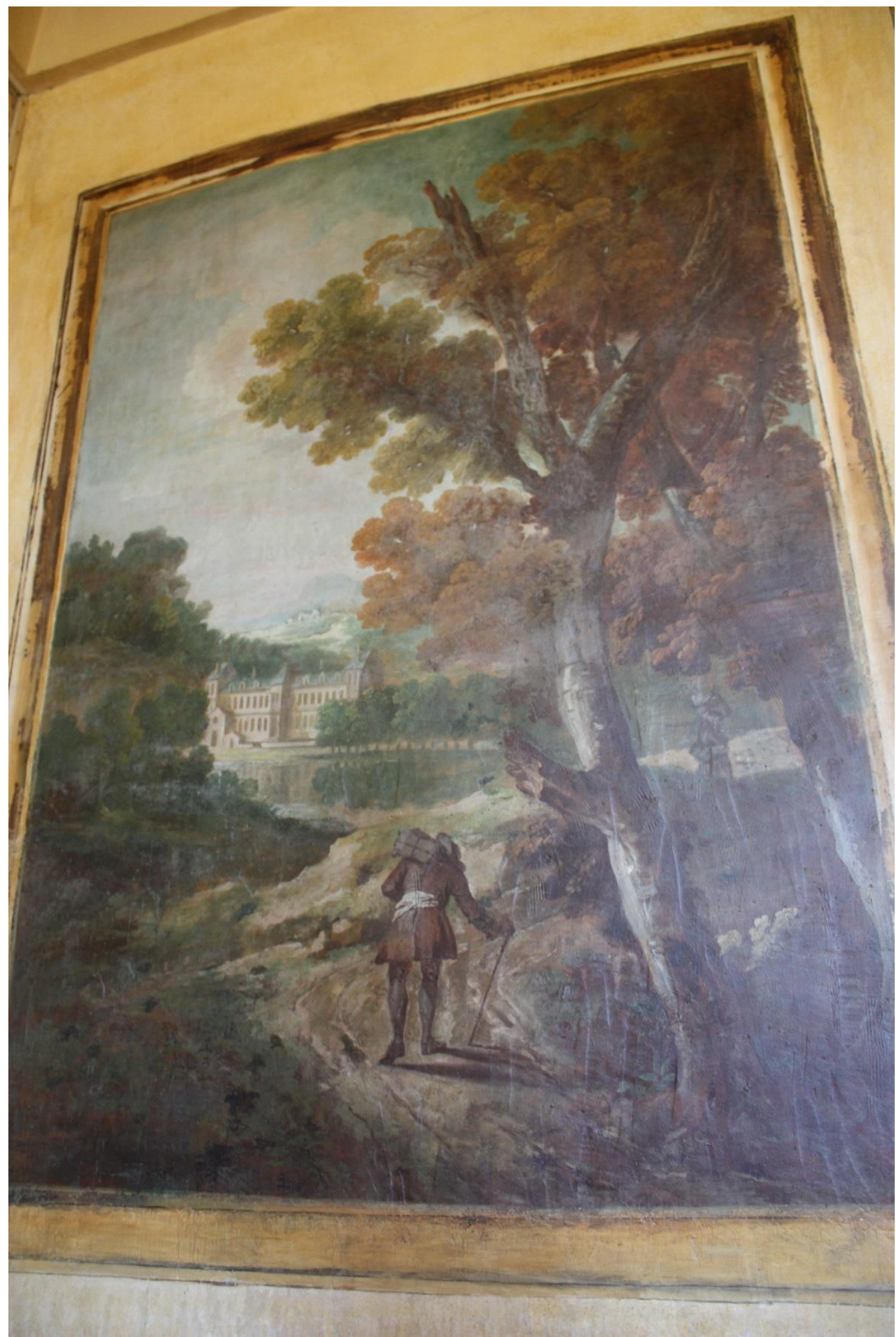

Figure 43: Attributed to Antoine Watteau, Figure in a landscape. Château de Condé en Brie. Image courtesy of the author. 
Figure 44: Nicolas Lancret, La Terre, before 1732. Oil on Canvas, 38 x $31 \mathrm{~cm}$, Museo Nacional Thyssen-Bornemisza, Madrid. 
Figure 45: Nicolas Lancret, L'Eau, before 1732 . Oil on Canvas, 39.40 x $31.80 \mathrm{~cm}$, The National Galleries of Scotland, Edinburgh. 
Figure 46: Nicolas Lancret, Le repas au retour de chasse, c. 1725 . Oil on Canvas, $90.3 \mathrm{x}$ 123.5 cm, Musée du Louvre, Paris. 
Figure 47: Antoine Watteau, Le bal champêtre, 1713/1714. Oil on Canvas, 96 x $128 \mathrm{~cm}$, Private Collection. 
Figure 48: Antoine Watteau, Les plaisirs du bal, 1715-17. Oil on Canvas, 52.6 x $65.4 \mathrm{~cm}$, Dulwich Picture Gallery, London. 
Figure 49: Antoine Watteau, Rendez-vous de Chasse, 1717-1718. Oil on Canvas, $124.5 \mathrm{x}$ $189 \mathrm{~cm}$, The Wallace Collection, London. 
Figure 50: Benoit Audran, Engraving after Antoine Watteau, Retour de chasse. Musée du Louvre, Paris. 
Figure 51: Antoine Watteau, Huntress with Dogs, 1713-1714. Red chalk and brown pen on paper, 40.3 x $54.1 \mathrm{~cm}$, Städel Museum, Frankfurt. 
Figure 52: Nicolas Lancret, Halte de Chasseurs, c. 1720-1730. Oil on Canvas, 86 x $107 \mathrm{~cm}$, Private Collection. 


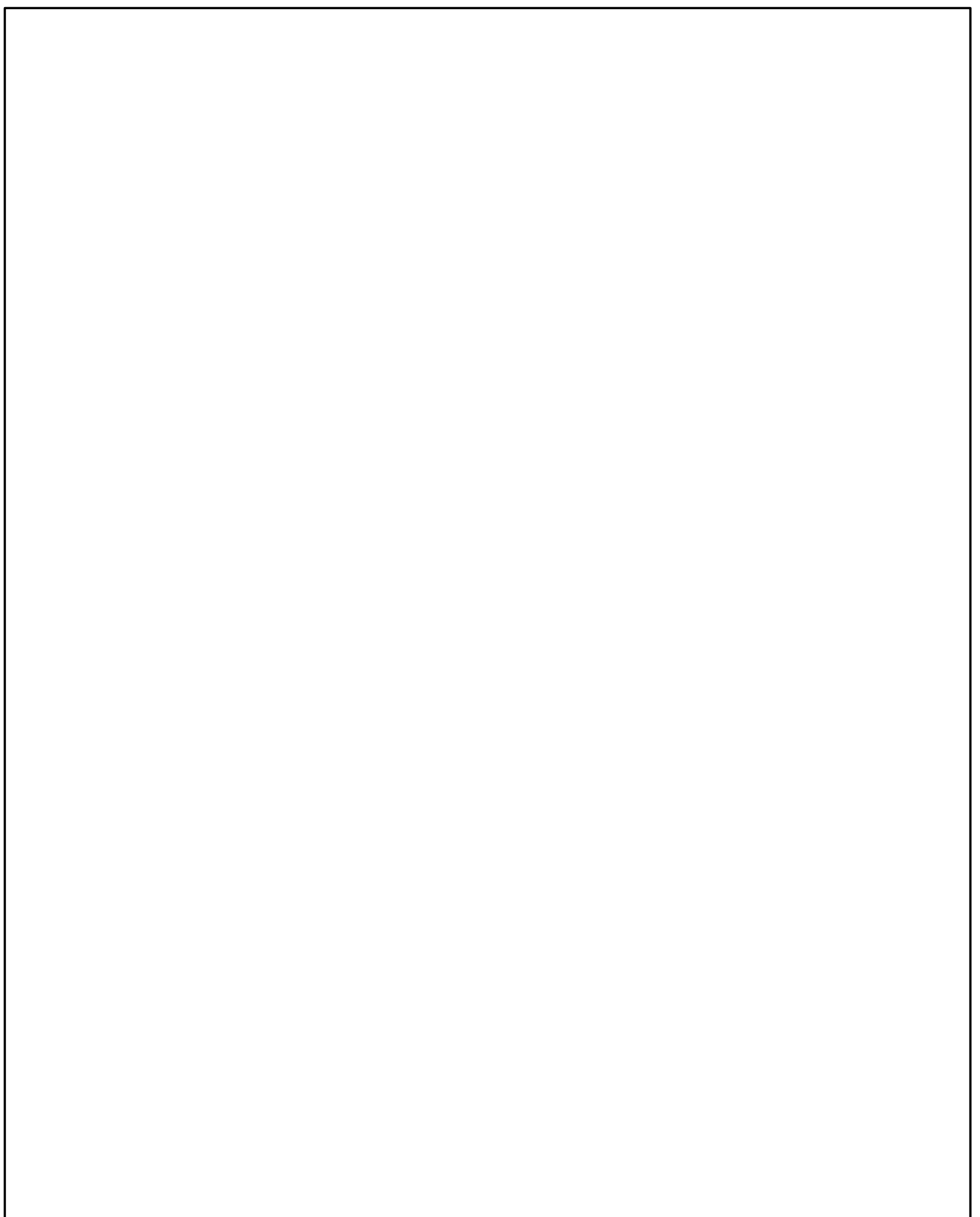

Figure 53: Nicolas Lancret, A Hunter and His Servant, c. 1737-1740. Oil on Canvas, 82.5 x $65 \mathrm{~cm}$, Private Collection. 
Figure 54: Nicolas Lancret, La fin de chasse, c. 1720-1725. Oil on Canvas, 112 x $145 \mathrm{~cm}$, Location Unknown. 
Figure 55: Nicolas Lancret, La Camargo Dancing, c. 1729-30. Oil on Canvas, 76 x 107 $\mathrm{cm}$, The National Gallery of Art, Washington D.C., Andrew W. Mellon Collection. 
Figure 56: Peter Paul Rubens, Garden of Love, c. 1633. Oil on Canvas, $198 \mathrm{~cm}$ x $283 \mathrm{~cm}$, Prado Museum of Art. 
Figure 57: Peter Paul Rubens, Chateau in a Park, c. 1632/1635. Oil on Wood, $52.5 \mathrm{~cm} \mathrm{x}$ $97 \mathrm{~cm}$, Kunstistorisches Museum, Vienna.

Figure 58: Peter Paul Rubens, Kermesse, c. 1630-1638. Oil on Panel, $149 \times 261 \mathrm{~cm}$, Musée du Louvre, Paris. 
Figure 59: Hans Sebald Beham, Bauernfest (Kermis), c.1535. Woodcut, $38.9 \times 53.9 \mathrm{~cm}$, Graphische Sammlung der Universität Erlangen-Nürnberg. 
Figure 60: Antoine Watteau, La Mariée de village, c. 1710-12. Oil on Canvas, 65 x 92 $\mathrm{cm}$, Stifung Preußische Schlösser und Gärten, Berlin-Brandenburgh, Berlin, Schloss Charlottenburg. 
Figure 61: Antoine Watteau, L'Accordée du village, c. 1708-1710. Oil on Canvas, $63 \mathrm{x}$ $92 \mathrm{~cm}$, Sir John Soane's Museum, London. 
Figure 62: Willem Kalf, Kitchen Interior, c. 1645 / c.1735. Oil on panel, 25.4 x 21 cm, photograph after conservation. The Saint Louis Museum of Art, Saint Louis, Missouri. 
Figure 63: Esaias van de Velde, The fête champêtre, 1615. Oil on Canvas, $34.7 \times 60.7$ cm, Rijksmuseum Amsterdam. 


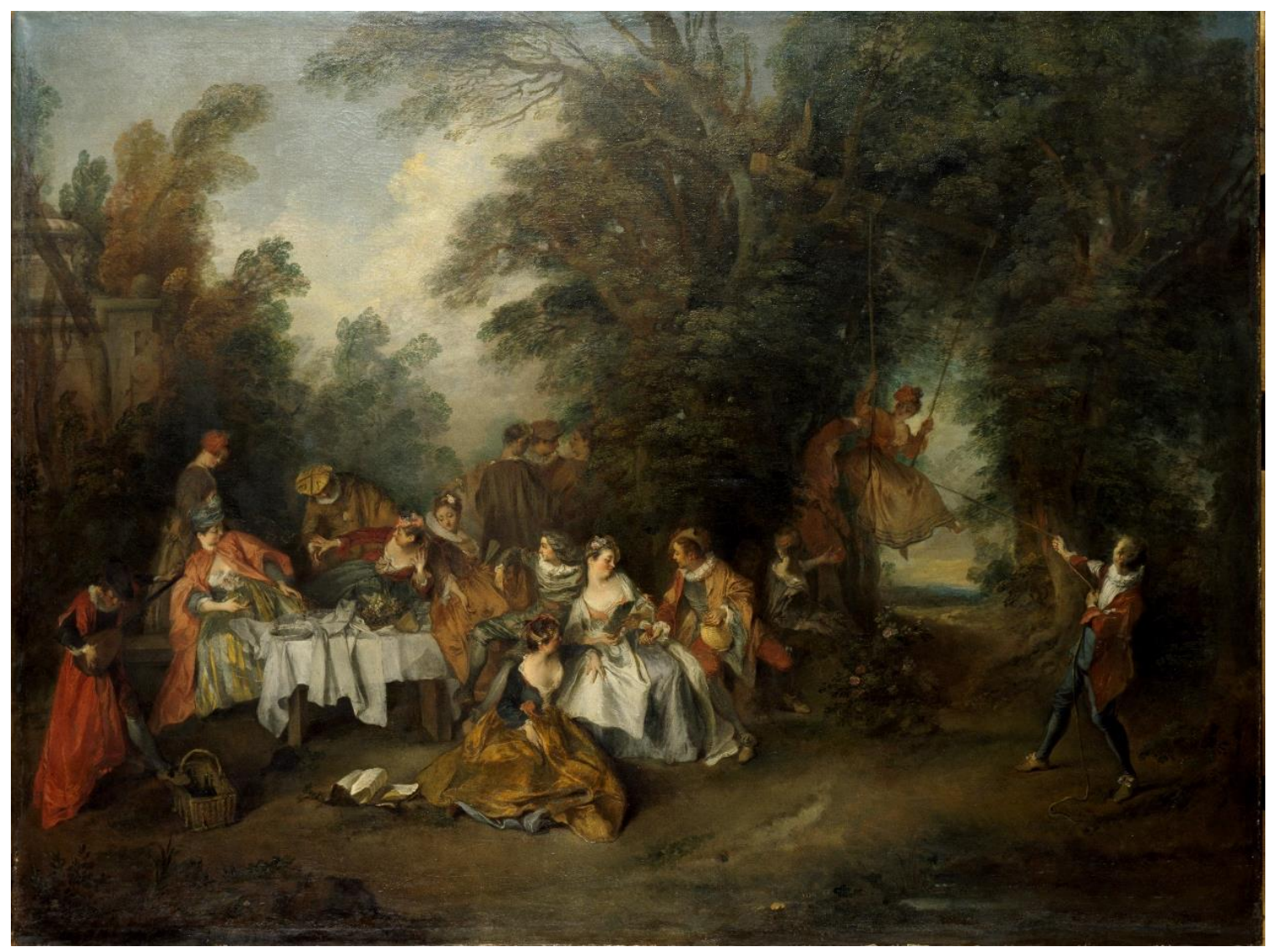

Figure 64: Nicolas Lancret, Le repas italien (The finished banquet), c. 1720, Oil on Canvas, 90 x $91 \mathrm{~cm}$, Stifung Preußische Schlösser und Gärten, Berlin-Brandenburgh, Berlin, Schloss Charlottenburg. Inv. No. GK 15658 Photo Credit: BPK Bildagenture/ Schloss Charlottenburg. 


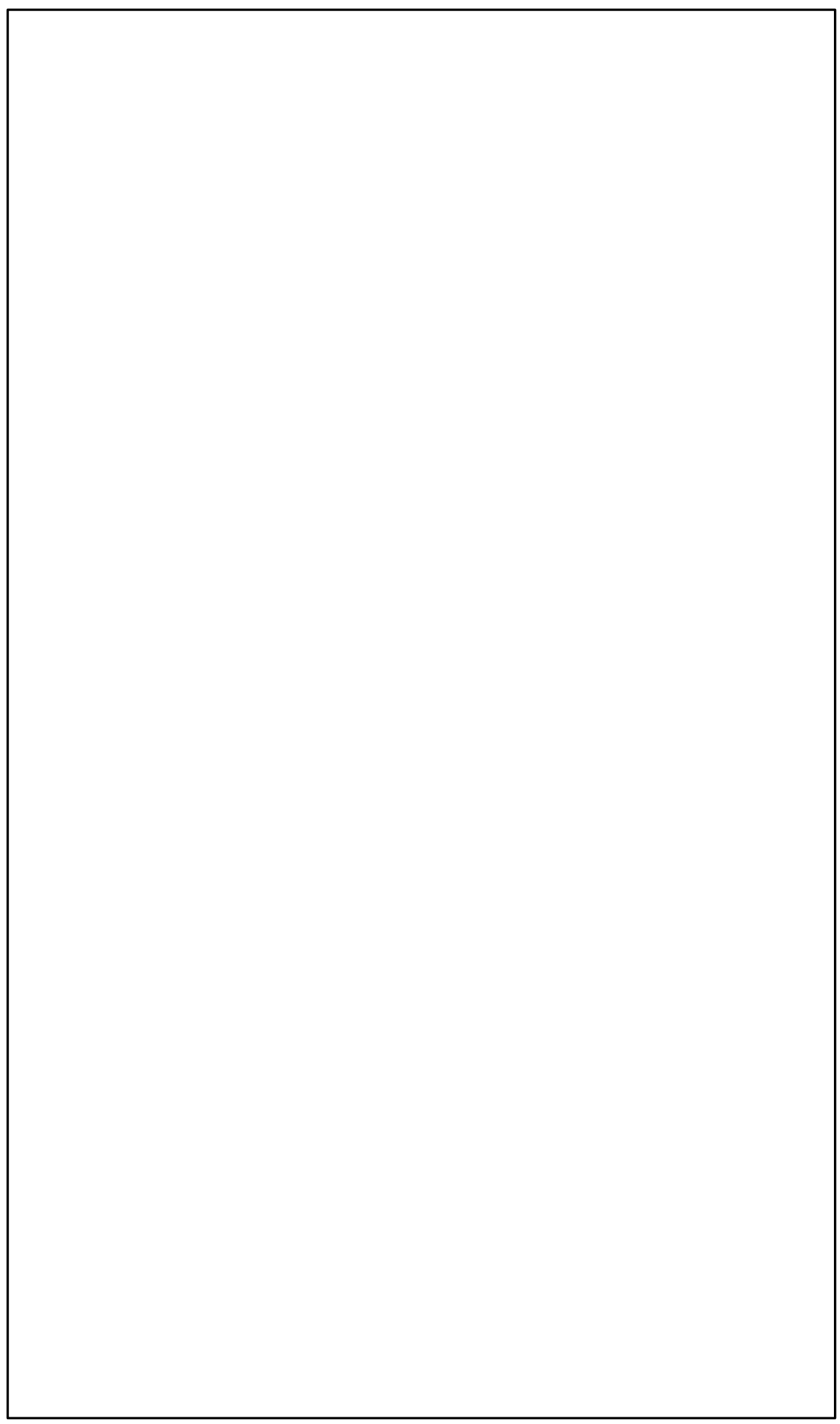

Figure 65: Nicolas Lancret, The Swing, 1723-27. Oil on Canvas, 150.80 x 89.70, The Cleveland Museum of Art. 


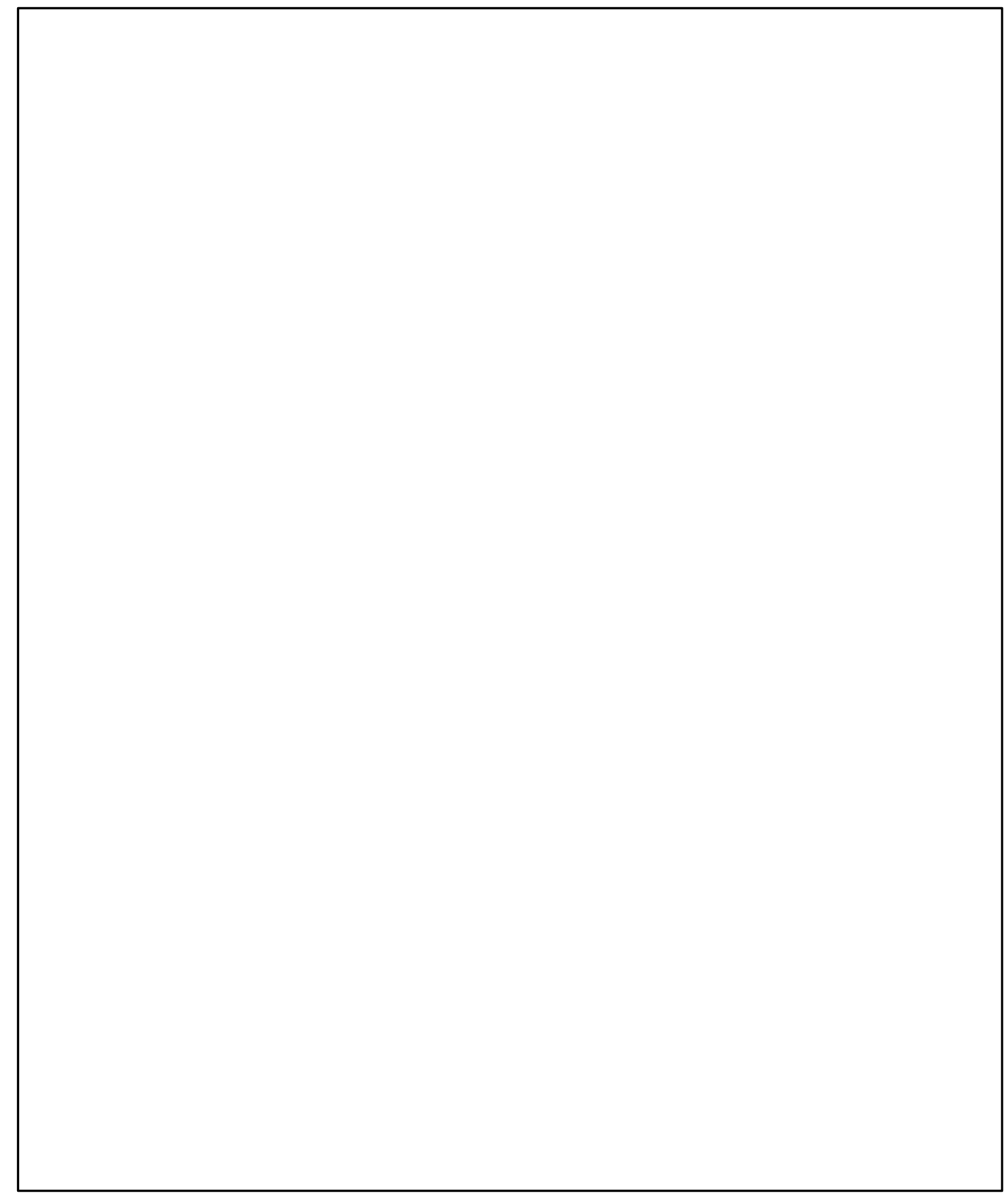

Figure 66: Nicolas Lancret, Dance in a Garden, c.1730. Oil on Canvas, 59.5 x $50.8 \mathrm{~cm}$, Ackland Art Museum, The University of North Carolina at Chapel Hill. 


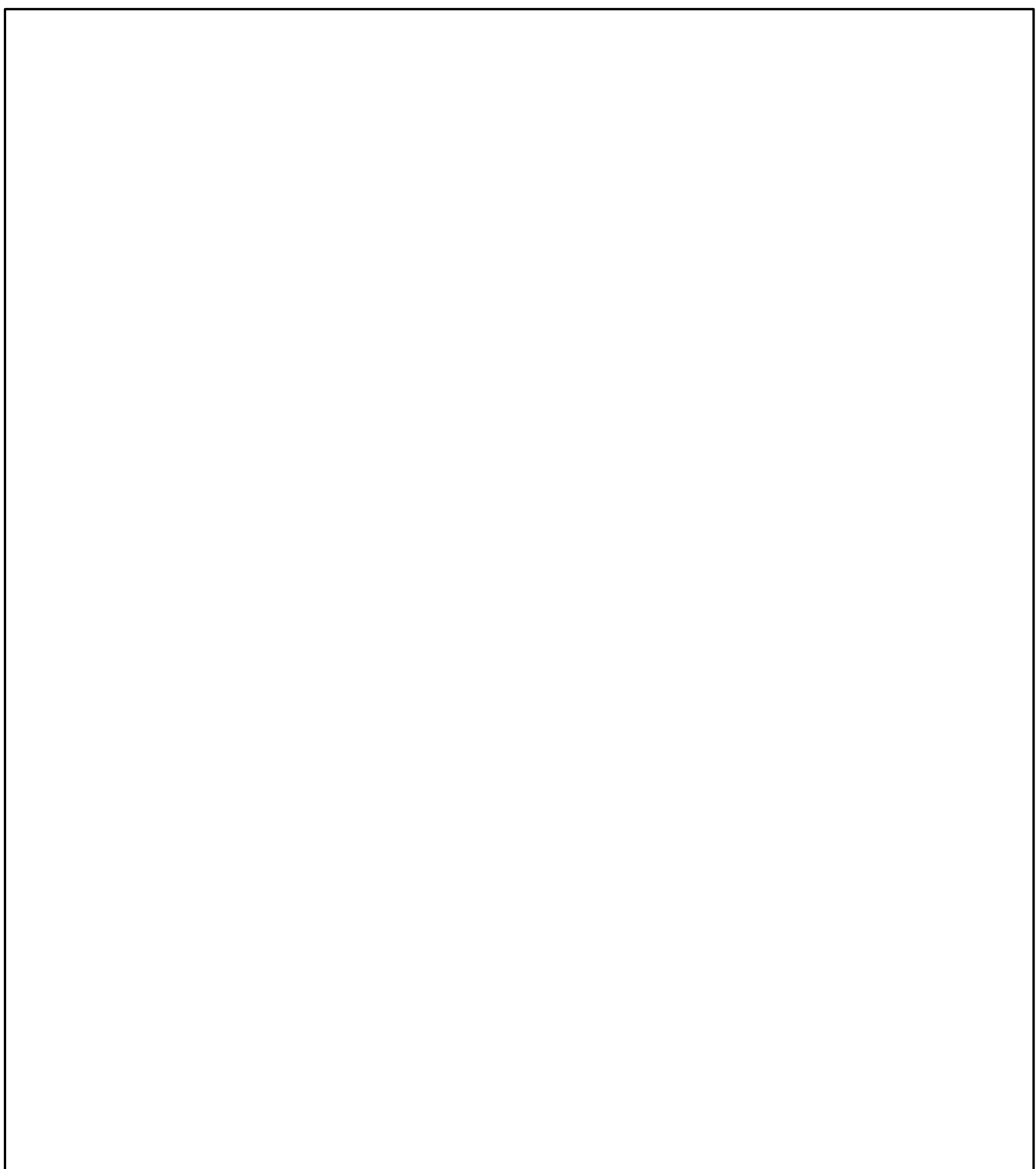

Figure 67: Nicolas Lancret, La danse dans le parc, c. 1720. Oil on Canvas, 116.5 x 105.5 cm., Private Collection. 


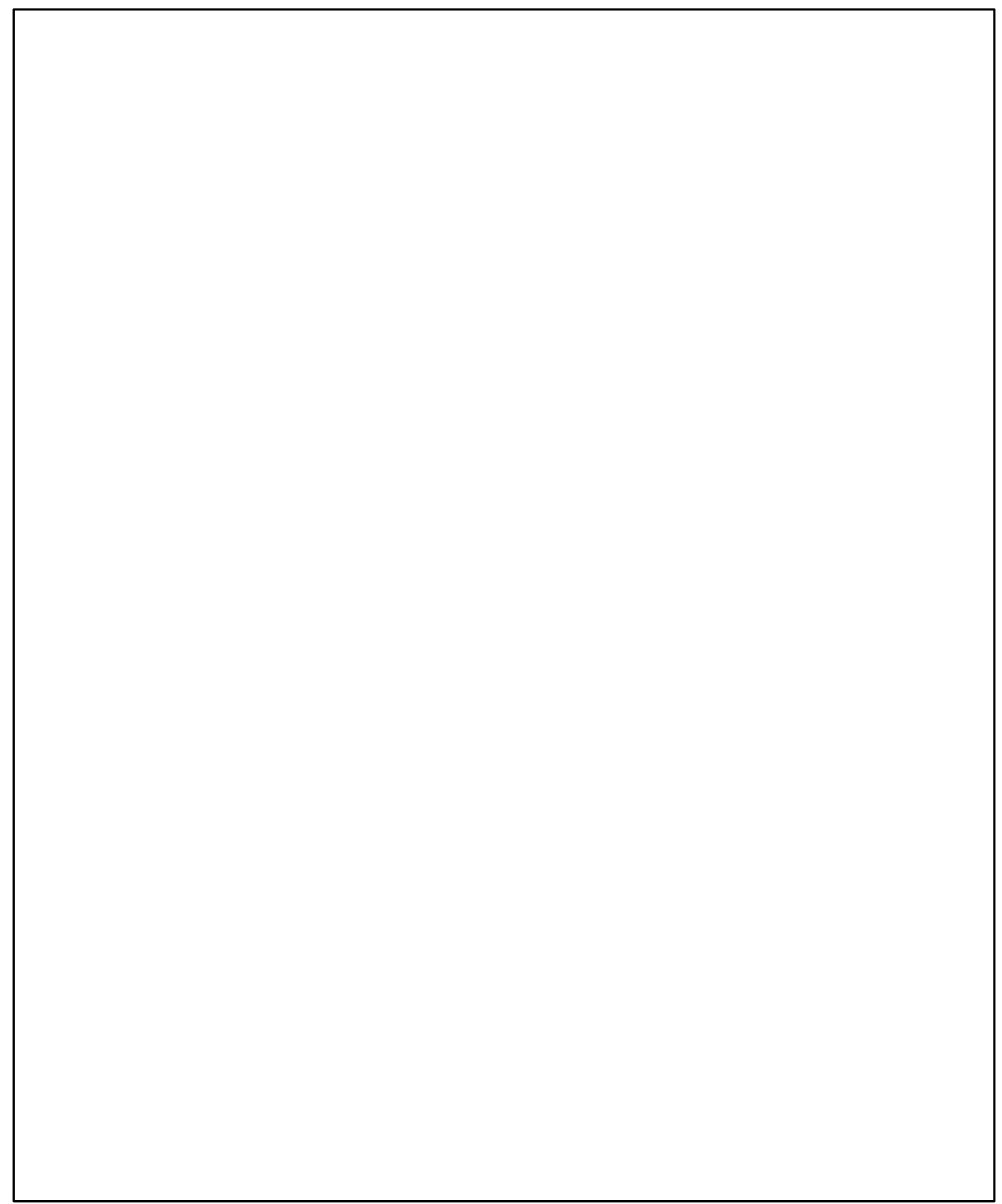

Figure 68: Nicolas Lancret, Une danse champêtre, c. 1740. Oil on Canvas, 43.5 x $36 \mathrm{~cm}$, Musée d'Angers, Angers, France. 


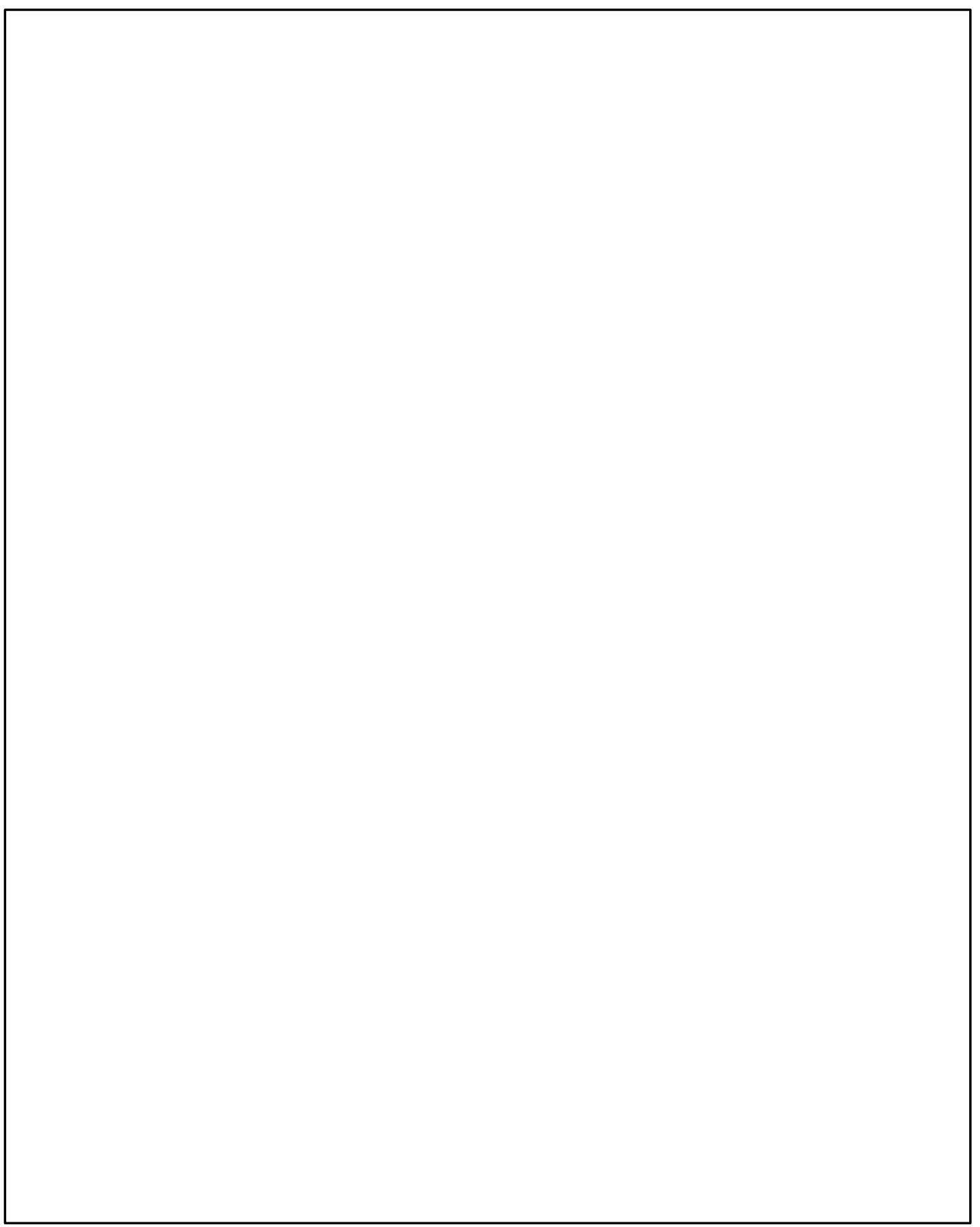

Figure 69: Antoine Watteau, Le Cortège de fiançailles, c. 1710-1712. Location Unknown. 
Figure 70: Nicolas Lancret, The Village Wedding, 1737-40. Oil on Canvas, 44 x $57.5 \mathrm{~cm}$, Waddesdon Manor, England. 
Figure 71: Pieter Bruegel, Peasant Kermis, c. 1567. Oil on Panel, 114 x 164 cm, Kunsthistorisches Museum, Vienna, Austria. 
Figure 72: Pieter Bruegel, Peasant Wedding Dance, 1566. Oil on Panel, $119.4 \mathrm{~cm} \times$ $157.5 \mathrm{~cm}$, Detroit Institute of Arts, Detroit, Michigan. 


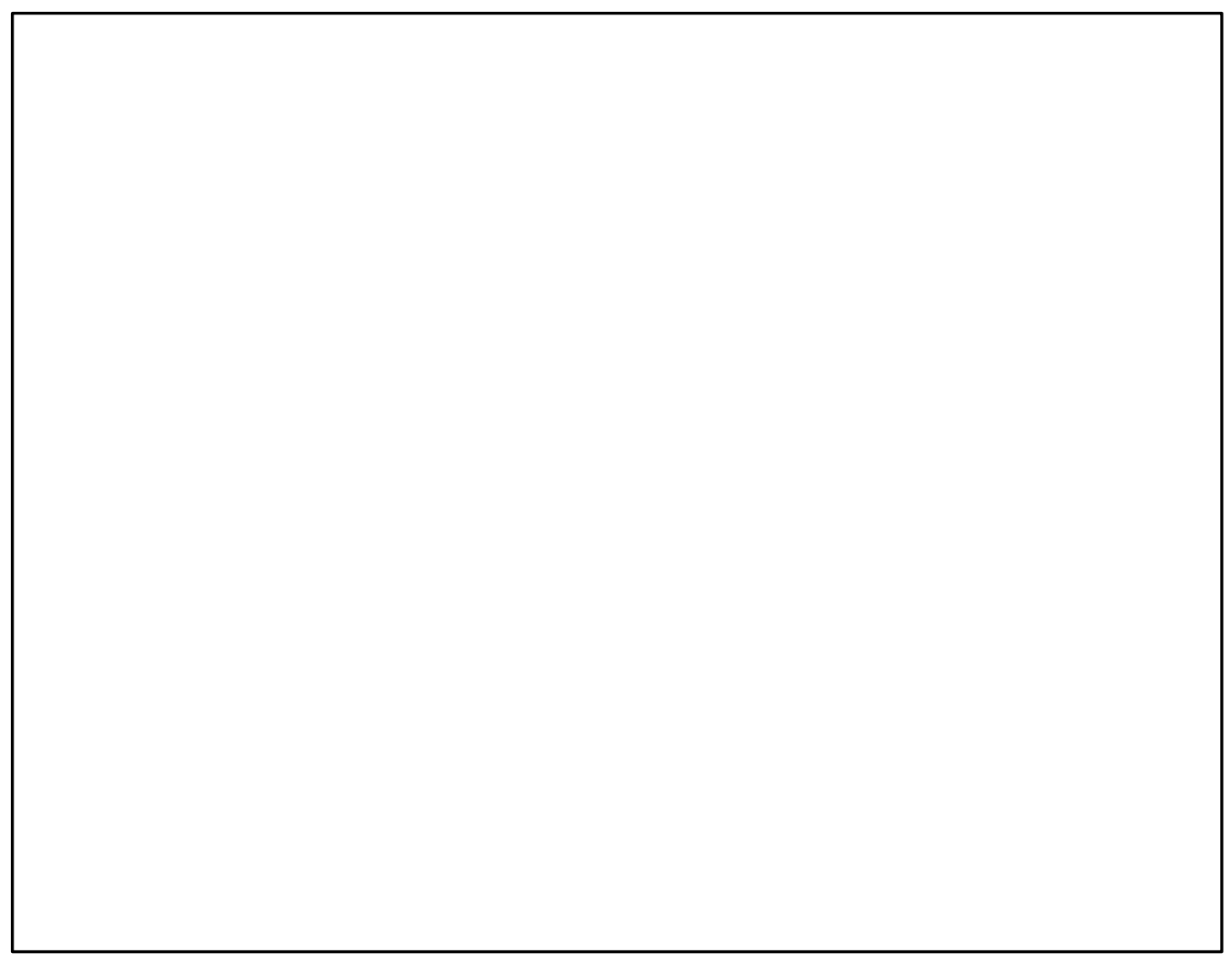

Figure 73: Nicolas Lancret, Le printemps, 1738. Oil on Canvas, 69 x 89 cm, Musée du Louvre, Paris. 
Figure 74: Nicolas Lancret, L'été, 1738. Oil on Canvas, 69 x 89 cm, Musée du Louvre, Paris. 


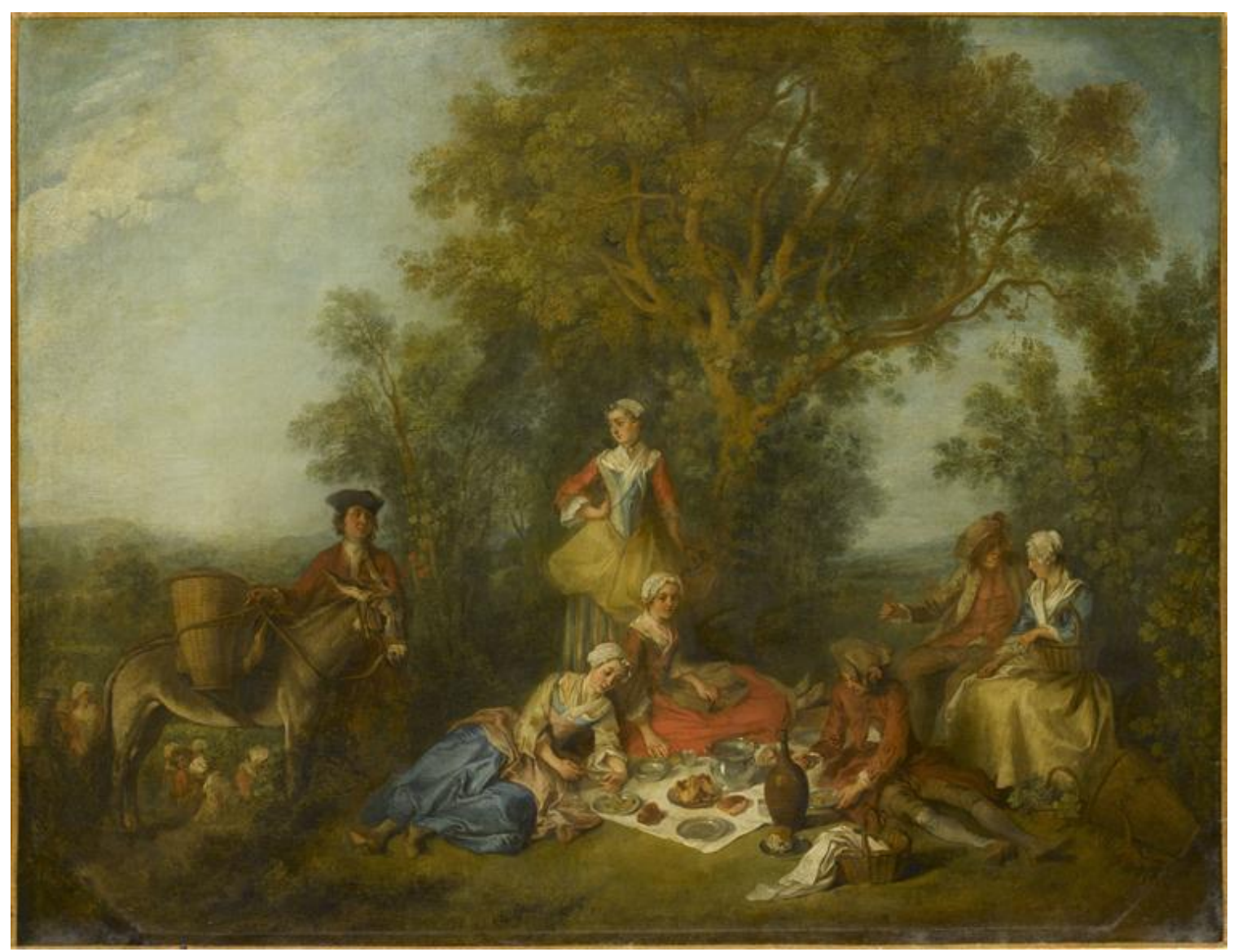

Figure 75: Nicolas Lancret, L'automne, 1738. Oil on Canvas, 69 x $89 \mathrm{~cm}$, Musée du Louvre, Paris, INV5599. Photo: Stéphane Maréchalle. ORMN-Grand Palais/Art Resource, NY. 
Figure 76: : Nicolas Lancret, L'Hiver, 1738. Oil on Canvas, 69 x 89 cm, Musée du Louvre, Paris. 
Figure 77: Jan van de Velde, September, 1616. Etching, $15.9 \mathrm{~cm}$ x $30.5 \mathrm{~cm}$, Amsterdam, Rijksmuseum.

Figure 78: Pieter Bruegel, Wheat Harvest, 1565. Oil on Wood, 119 x $162 \mathrm{~cm}$, The Metropolitan Museum of Art, NY. 
Figure 79: Pieter Bruegel, Return of the Herd, 1565. Oil on Wood, $117 \mathrm{~cm} \times 159 \mathrm{~cm}$, Kunsthistorisches Museum, Vienna. 
Figure 80: Pieter Bruegel, Hunters in the Snow, 1565. Oil on Wood, $117 \mathrm{~cm} \times 162 \mathrm{~cm}$, Kunsthistorisches Museum, Vienna. 


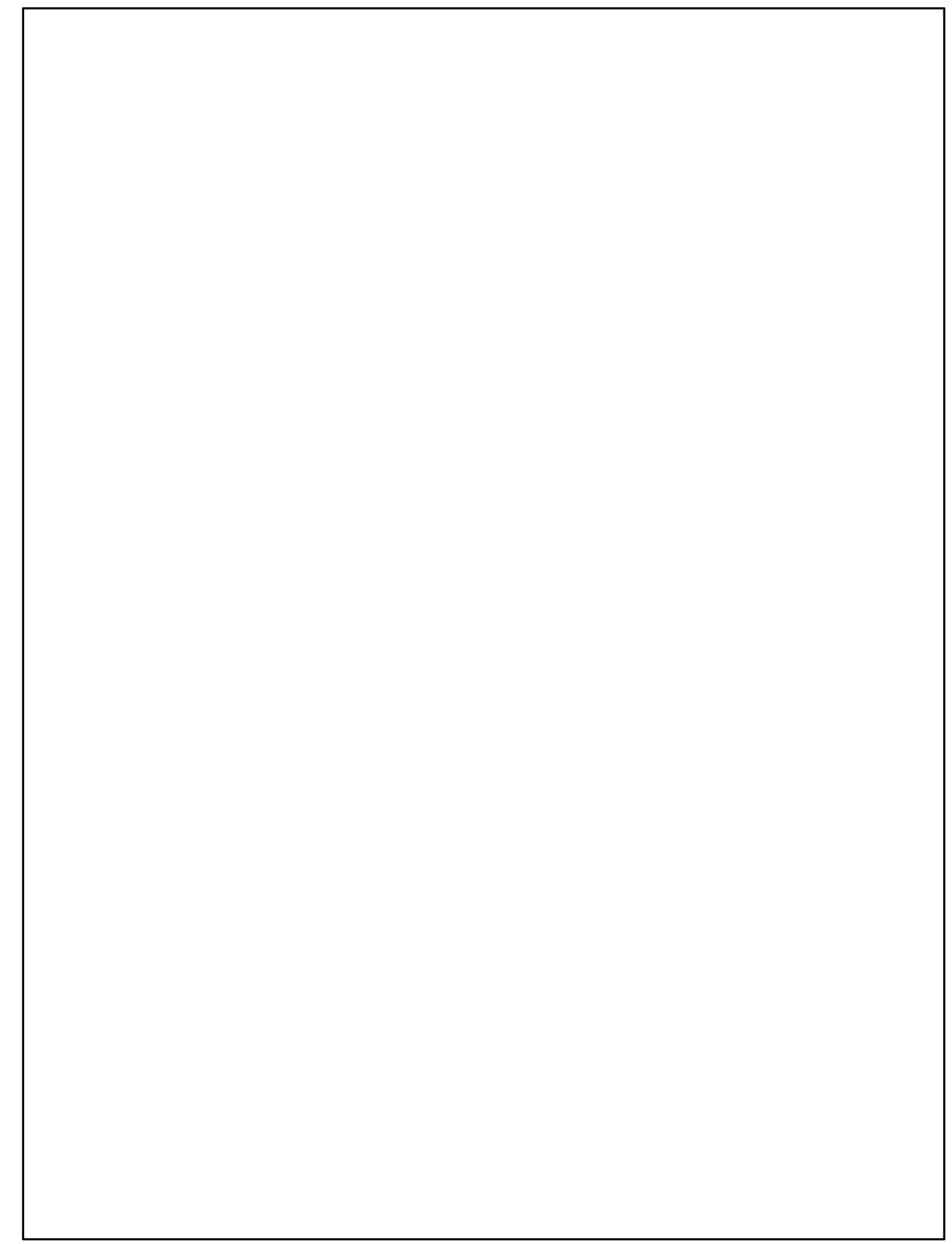

Figure 81: Bernard Audran, Engraving after Nicolas Lancret, Fire (from The Four Elements). c. 1732. Bibliothèque Nationale, Paris, Cabinet des Estampes. 
Figure 82: Jean Mariette, Summer: St. John's Fire. Engraving, Bibliothèque Nationale, Paris, Cabinet des Estampes. 


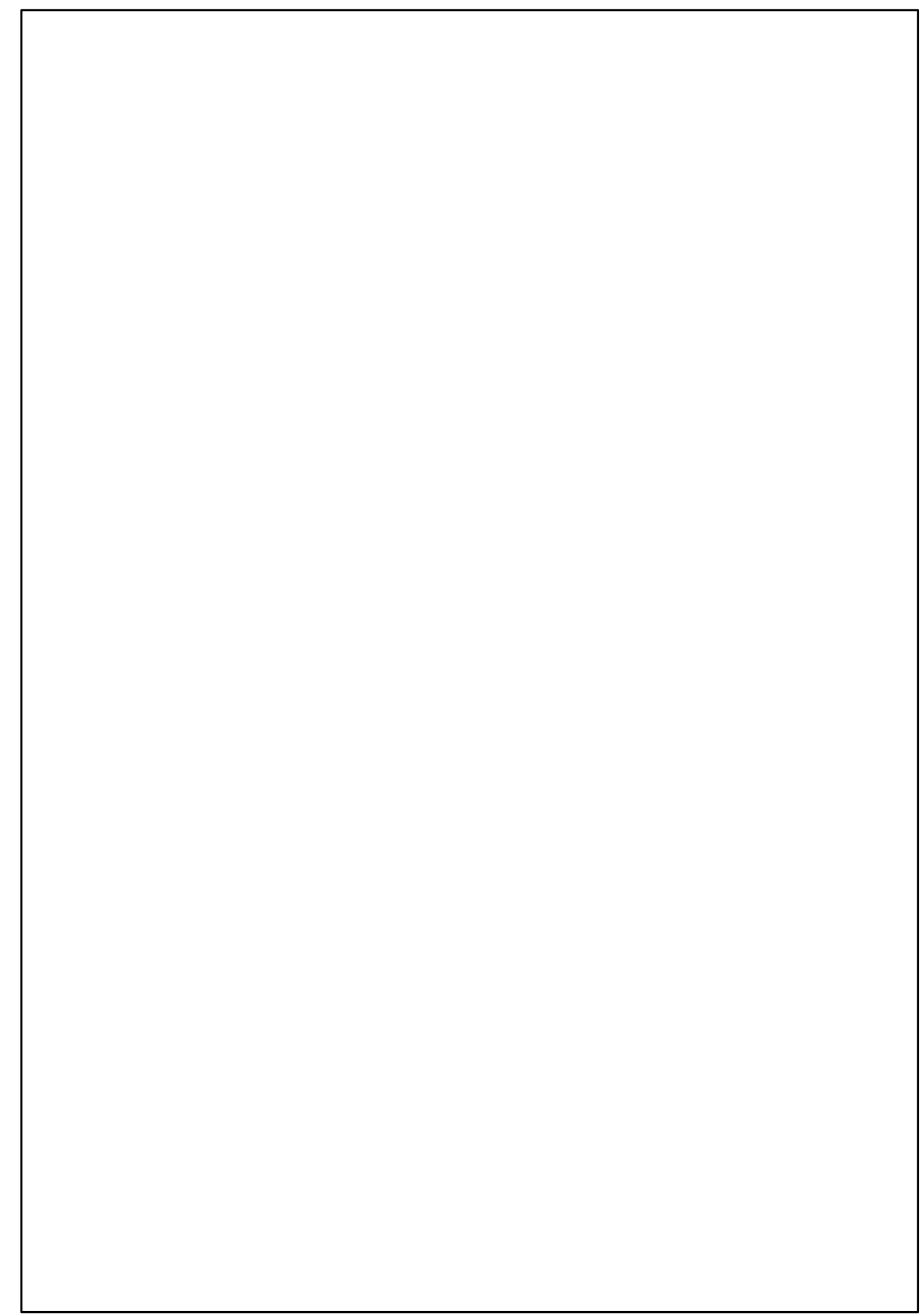

Figure 83: Frontispiece from Philippe Sylvestre Dufour, Traitez Nouveaux \& Curieux du Café, du Thé et du Chocolate. (La Haye: Chez Adrian Moetjens, 1685). Bibliothèque nationale de France, département Sciences et techniques, 8-TC24-11 (A). 
Figure 84: Guillaume Pigerone, Chocolatière, 1769, Musée des Arts Décoratifs, Paris, INV. 3485. 


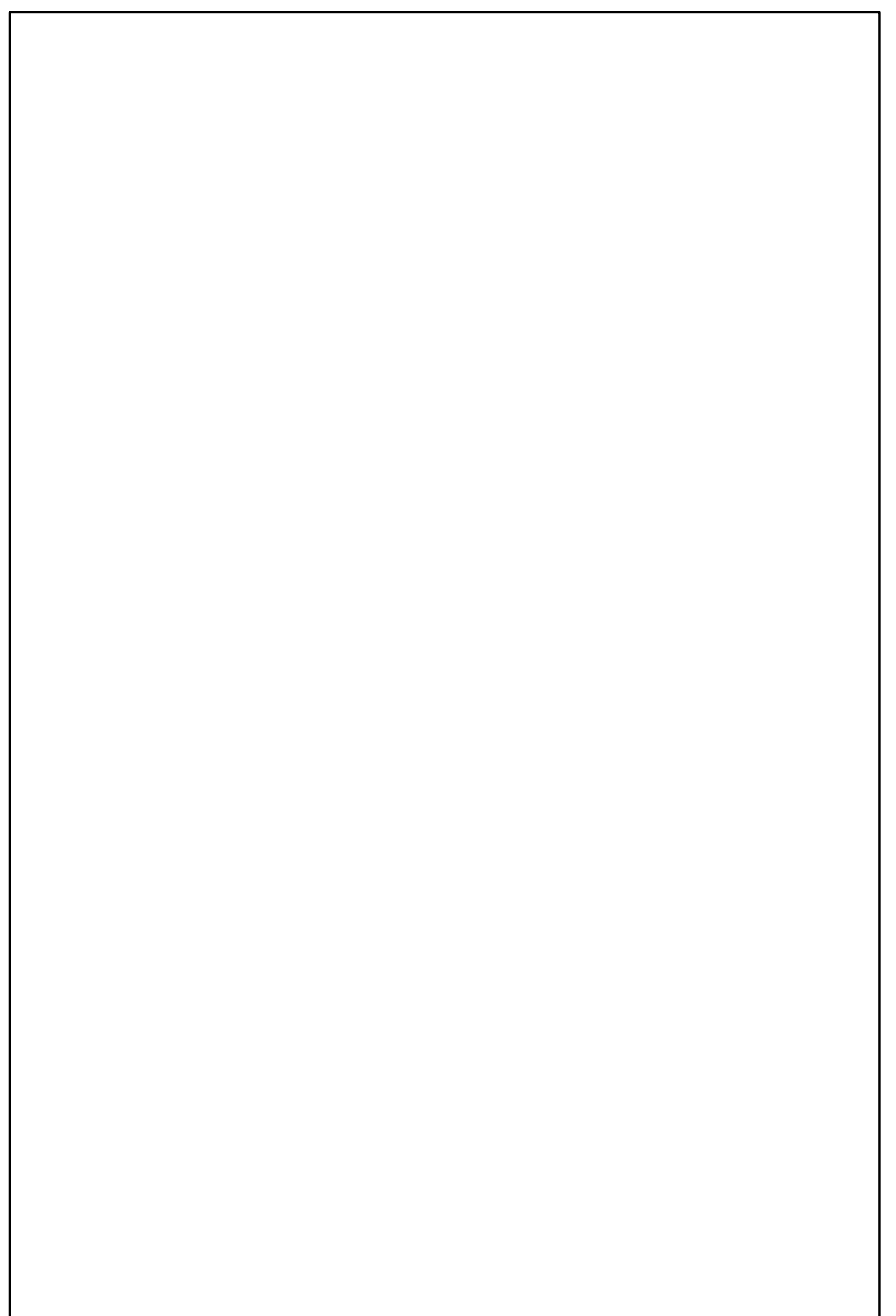

Figure 85: Chocolate pot, Meissen Manufacture, c. 1720. Musée des Arts Décoratifs, Paris, INV. 31910. 


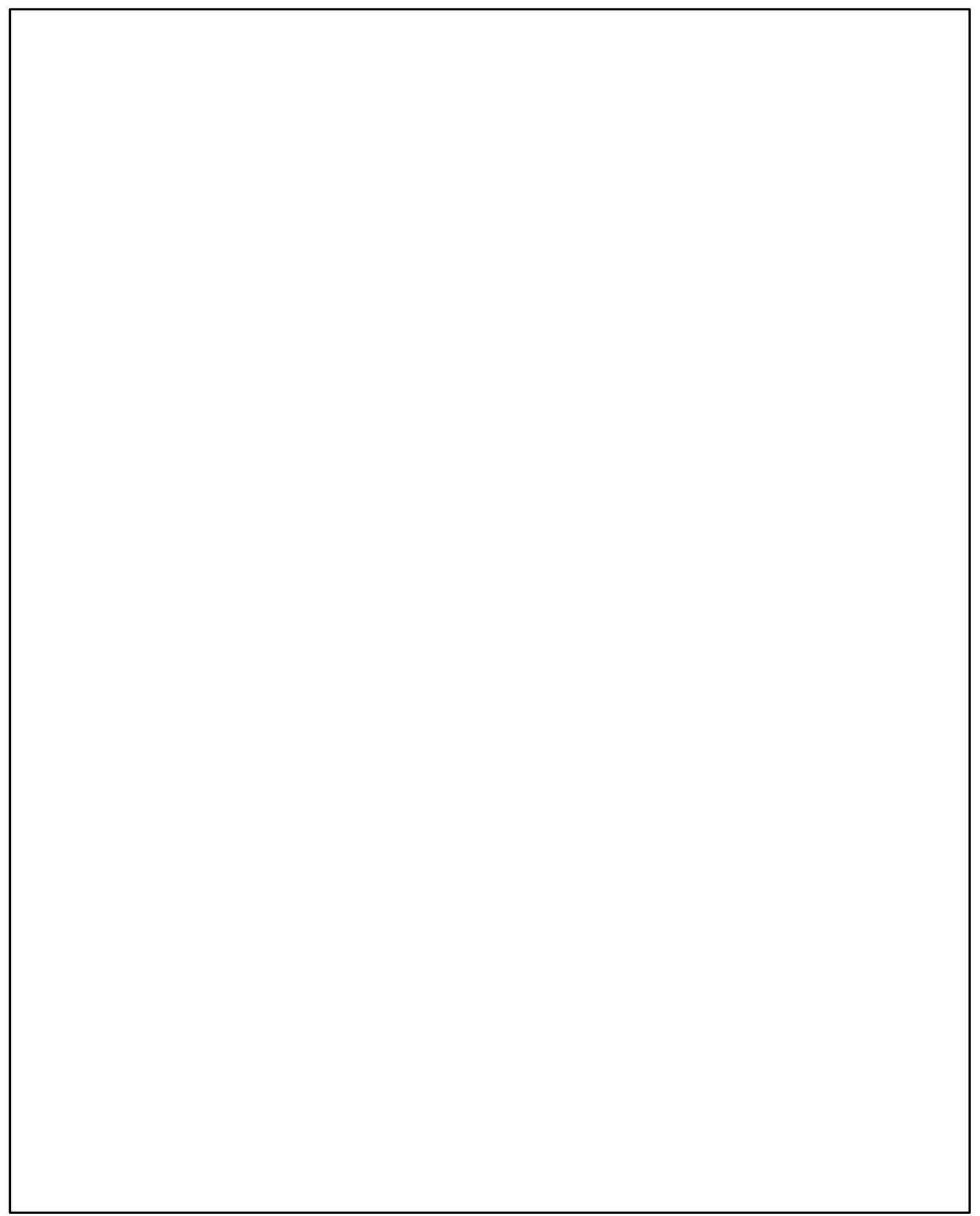

Figure 86: Examples of moulinets, from Sophie D. Coe and Michael D. Coe. The True History of Chocolate. (New York: Thames and Hudson, Inc., 1996), 116. 
Figure 87: Teapot, Hard-Paste Porcelain, Meissen Manufactory, c. 1735-45. The Metropolitan Museum of Art, NY, INV. 02.6.120 ab. 
Figure 88: Edme-Francois Godin, Théière, France, 1769. Musée des Arts Décoratifs, Paris, INV. 26907. 
Figure 89: Cafetière, 1730-1780. Musée des Arts Décoratifs, Paris, INV. 29993. 
Figure 90: Teabowl, Soft-Paste Porcelain, Saint-Cloud, c. 1715-1730. The Metropolitan Museum of Art, NY, INV. 02.6.69. 


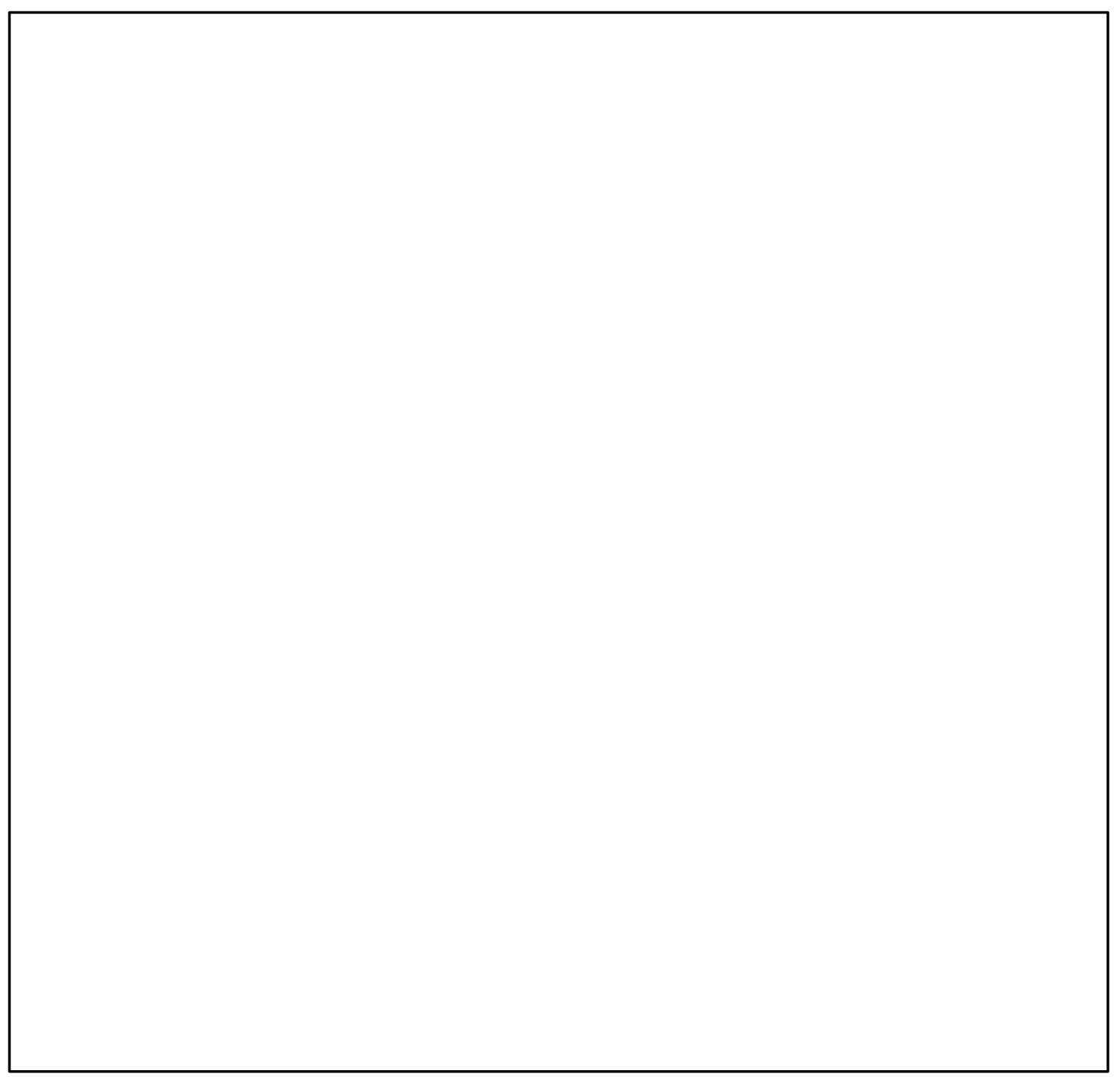

Figure 91: Teacup, tin-glazed soft-paste porcelain, Chantilly Manufactory, c. 1735-1740. The Metropolitan Museum of Art, NY, INV. 1995.268.153. 


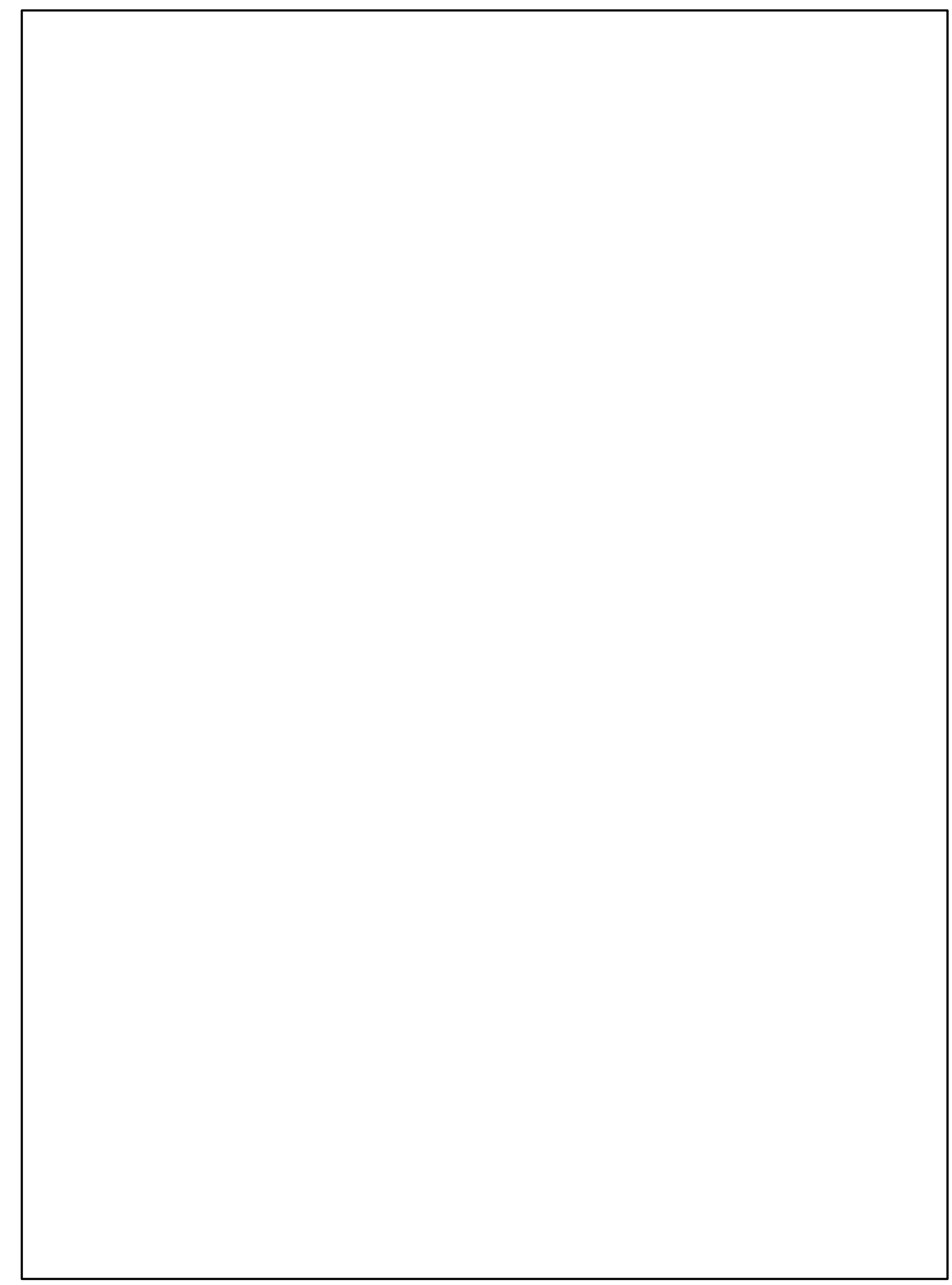

Figure 92: Nicolas Bonnart, A Cavalier and a Lady Drinking Chocolate, engraving, from Costumes du règne de Louis XIV. Bibliothèque nationale de France, Cabinet des estampes. 
Figure 93: Trembleuse cup and saucer, Hard-Paste porcelain, Du Paquier porcelain factory, Vienna, c. 1735-1740. The Victoria and Albert Museum, London, INV. C. 641949. 
Figure 94: Tea, coffee and chocolate service, ca. 1740, Meissen porcelain. From Maureen Cassidy-Geiger, ed. Fragile Diplomacy: Meissen Porcelain for European Courts ca. 1710-63. (New Haven: Yale University Press, 2007), 226. 
Figure 95: Nicolas Lancret, Les Heures du Jour: Le Matin, 1739. Oil on Copper, $28.3 \mathrm{x}$ $36.4 \mathrm{~cm}$, The National Gallery, London. 
Figure 96: Nicolas Lancret, Les Heures du Jour: Midi, 1739. Oil on Copper, 28.6 x 36.9 $\mathrm{cm}$, The National Gallery, London. 


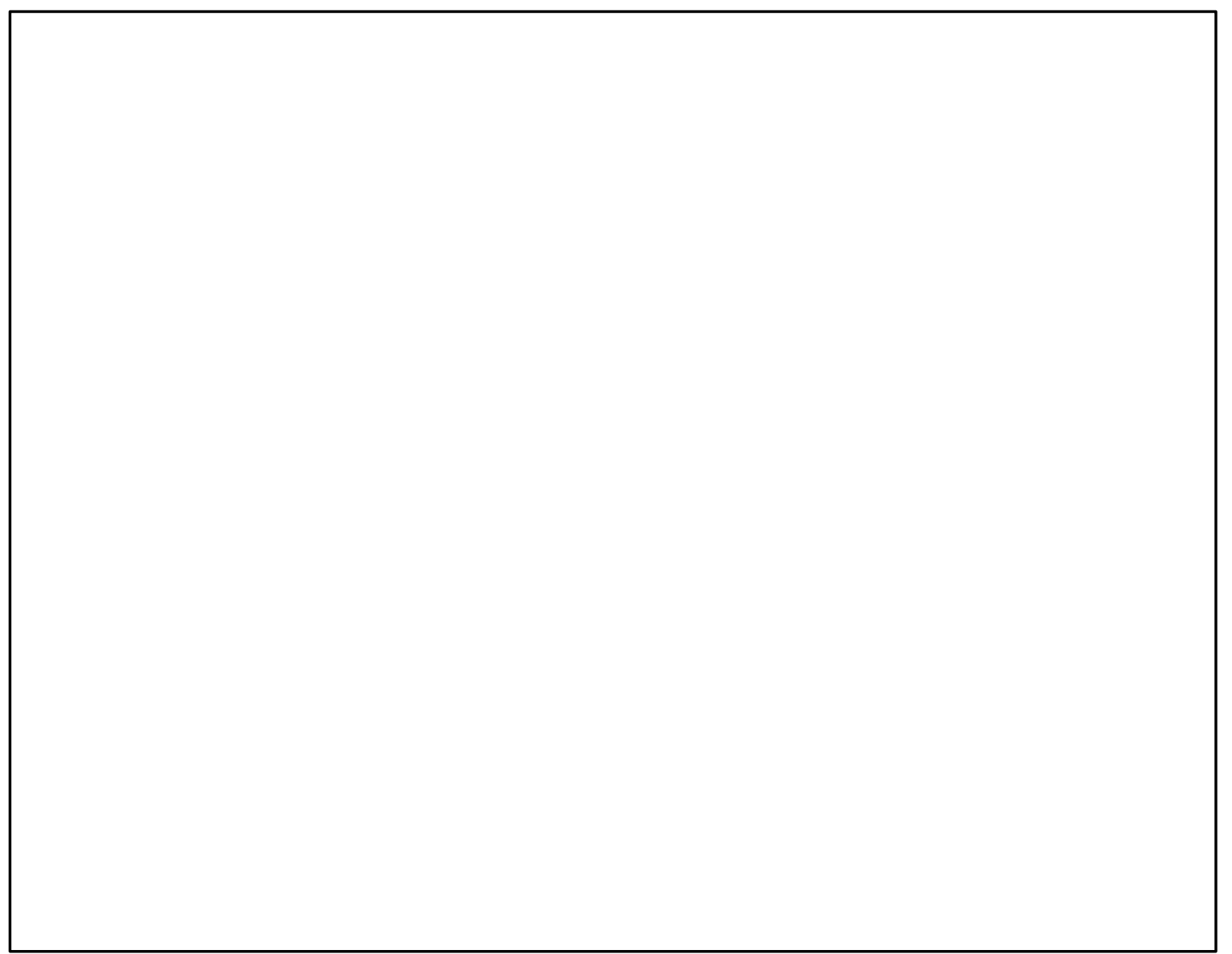

Figure 97: Nicolas Lancret, Les Heures du Jour : L'àpres-diner, 1739. Oil on Copper, 28.8 x $36.7 \mathrm{~cm}$, The National Gallery, London. 


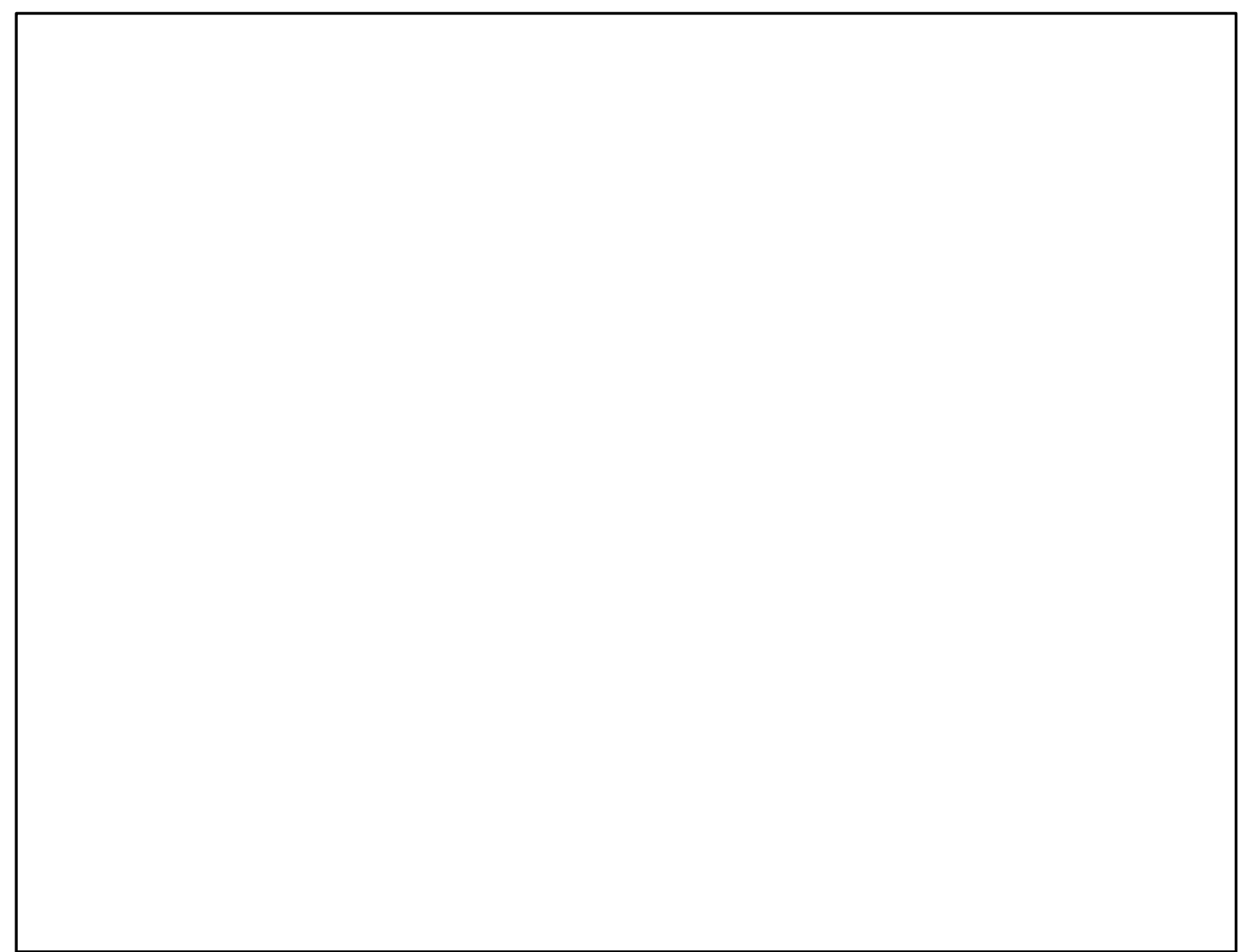

Figure 98: Nicolas Lancret, Les Heures du Jour : La Soirée, 1739. Oil on Copper, 28.8 x $36.8 \mathrm{~cm}$, The National Gallery, London. 


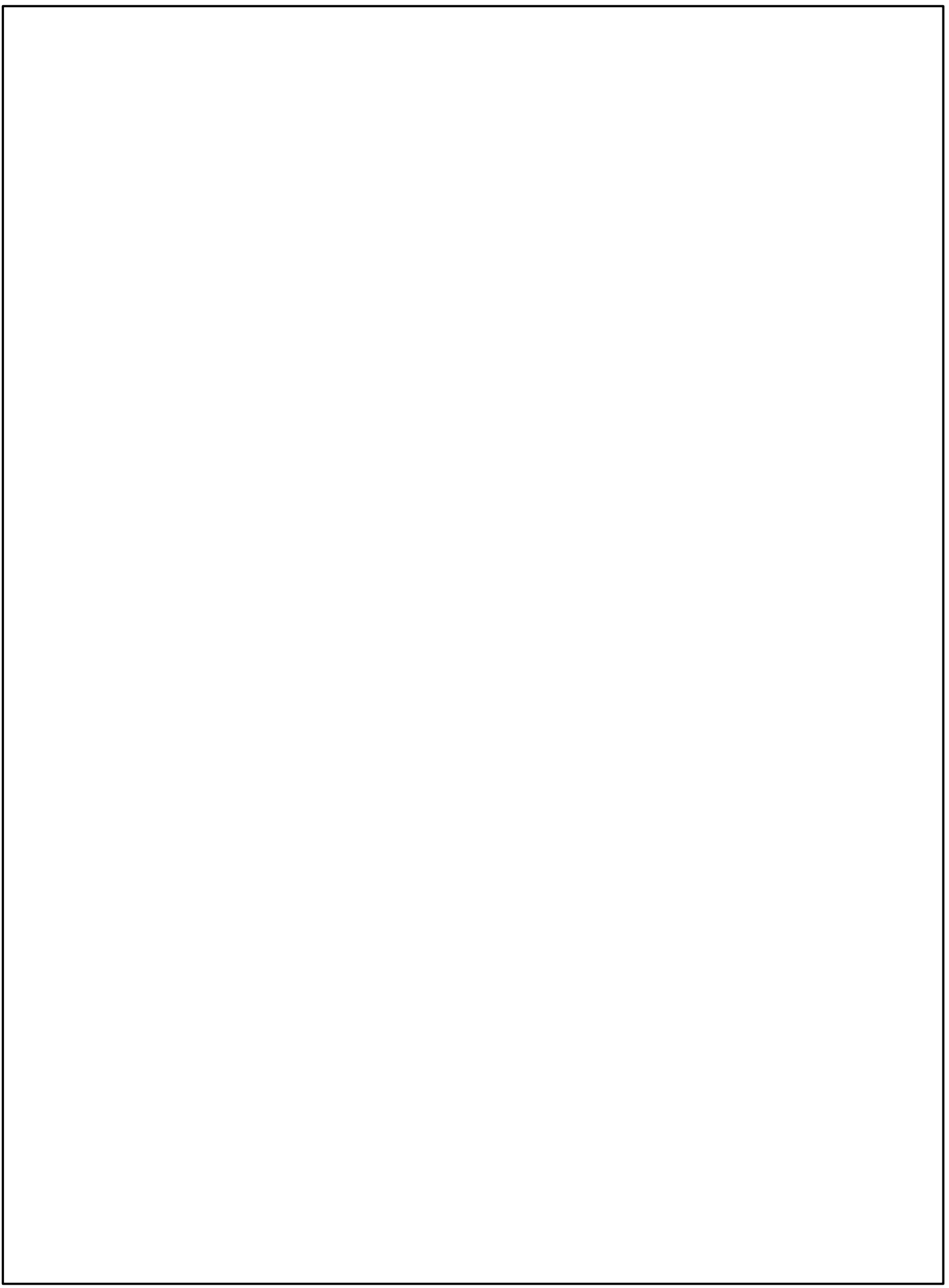

Figure 99: Image from Alfred Franklin, La Vie Privee d'Autrefois : le café, le thé \& le chocolat. (Paris: E. Plon, Nourrit et Cie, Imprimeurs-Editeurs, 1893) Figure 1, 9. 
Figure 100: : François Boucher, La Toilette, 1739. Oil on Canvas, 81.5 x $65.5 \mathrm{~cm}$, Musée du Louvre, Paris. 
Figure 101: Jean-Baptiste Le Prince, Fear, 1769. Oil on Canvas, 50 x 64 cm, Toldeo Museum of Art, Toldedo, Ohio.

Figure 102: Nicolas Lancret, La petit déjeuner avant la chasse, c. 1740. Oil on Canvas, 61 x $133.4 \mathrm{~cm}$, Fine Arts Museums of San Francisco, Legion of Honor. 
Figure 103: Nicolas Lancret, Concert Champetre, c. 1740. Oil on Canvas, 61 x $128.9 \mathrm{~cm}$, Fine Arts Museums of San Francisco, Legion of Honor.

Figure 104: Nicolas Lancret, Le Fin de la Chasse, c. 1740. Oil on Canvas, 60.3 x 135.1 $\mathrm{cm}$, Fine Arts Museums of San Francisco, Legion of Honor. 
Figure 105: Nicolas Lancret, Baigneuses, c. 1740. Oil on Canvas, 61 x $129.5 \mathrm{~cm}$, Fine Arts Museums of San Francisco, Legion of Honor. 
Figure 106: Nicolas Lancret, A Lady and Gentleman with Two Girls in a Garden, 1742. Oil on Canvas, 88.9 x $97.8 \mathrm{~cm}$, The National Gallery, London. 


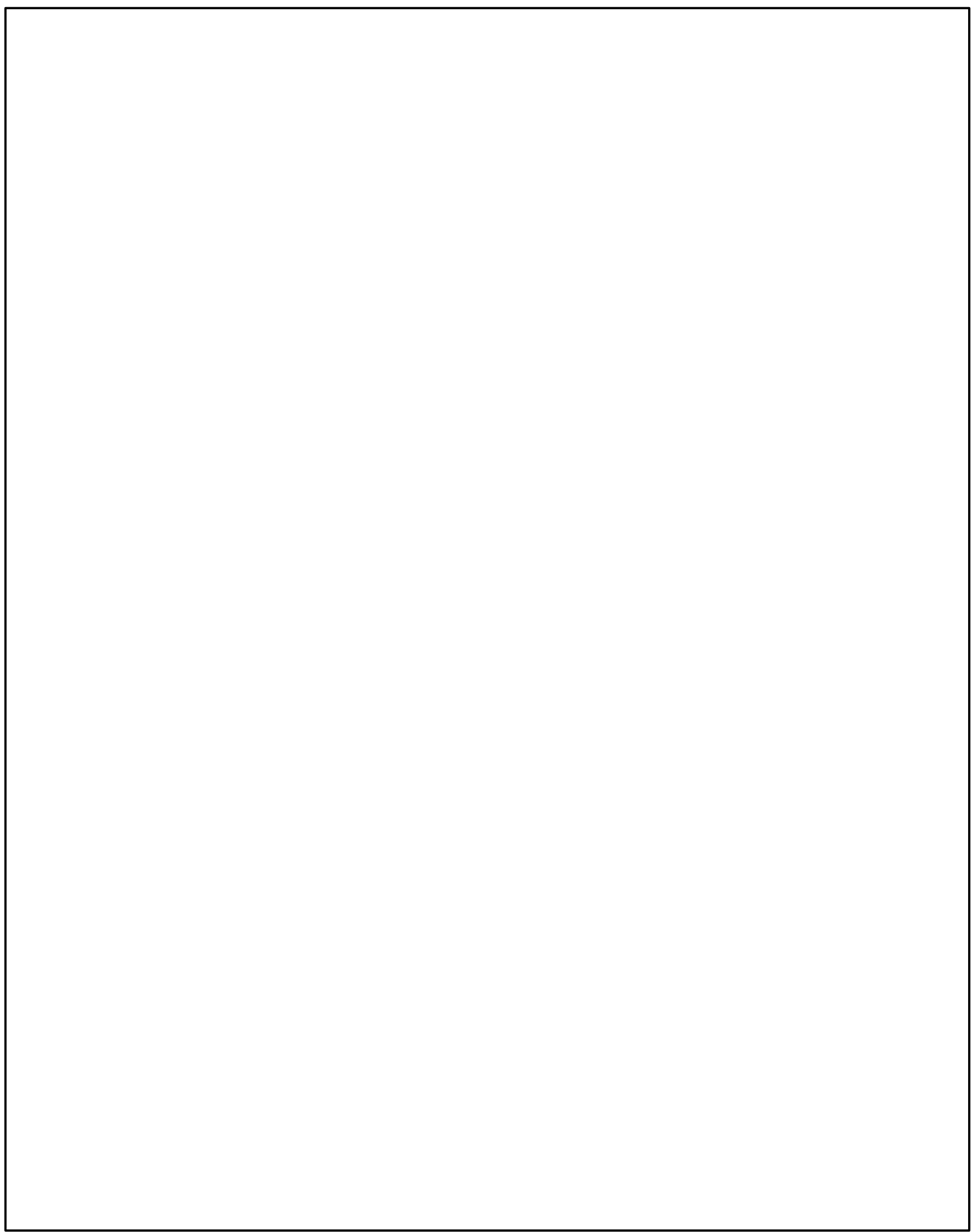

Figure 107: François Boucher, Le Déjeuner, 1739. Oil on Canvas, 81.5 x $65.5 \mathrm{~cm}$, Musée du Louvre, Paris. 


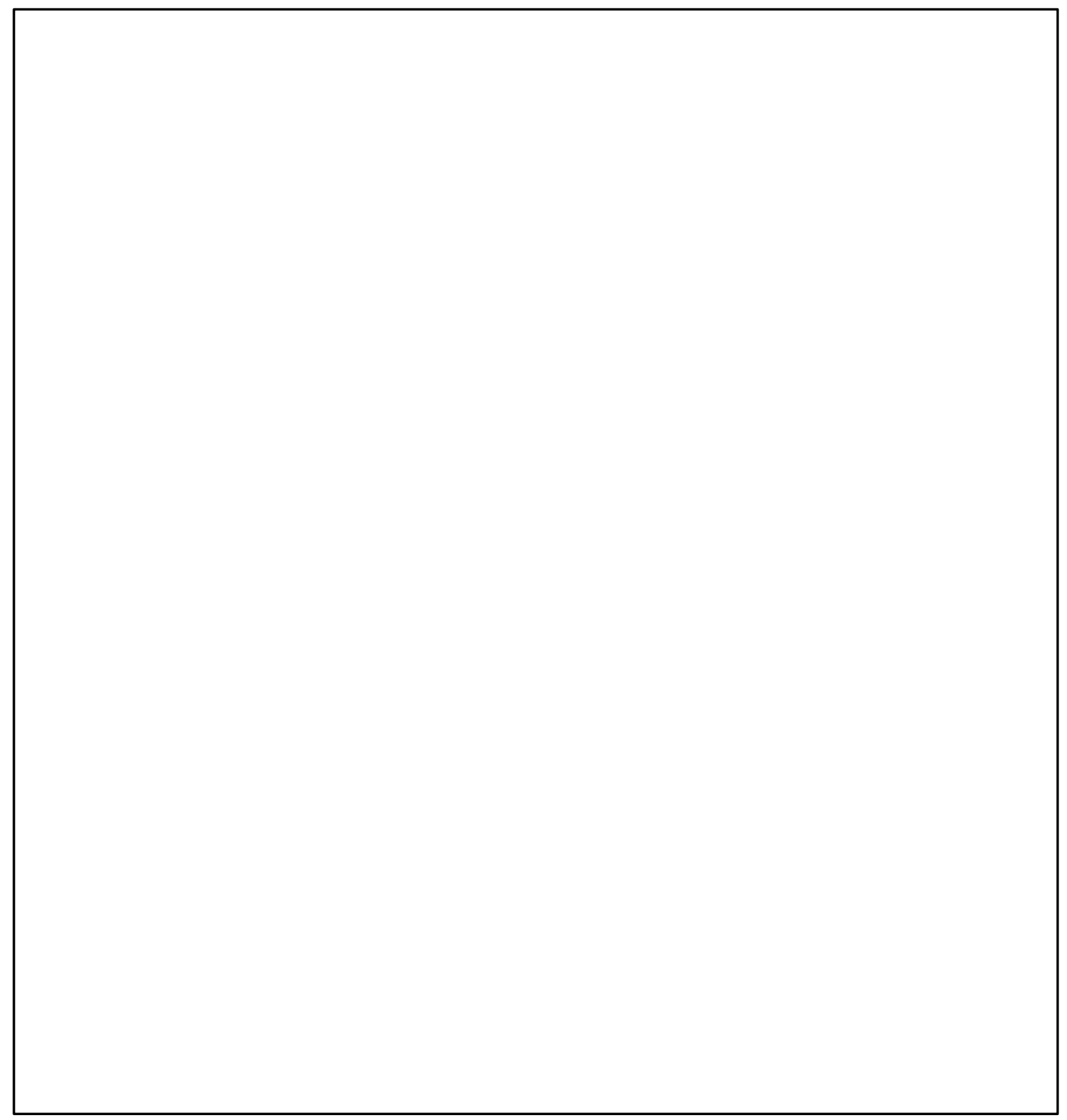

Figure 108: Joseph Parrocel, The Boar Hunt, ca. 1700. Oil on Canvas, 109 x $104.1 \mathrm{~cm}$. The National Gallery, London. 
Figure 109: Nicolas Lancret, Les Plaisirs de bain, 1725. Oil on Canvas, 100 x $154 \mathrm{~cm}$. Musée du Louvre, Paris. 


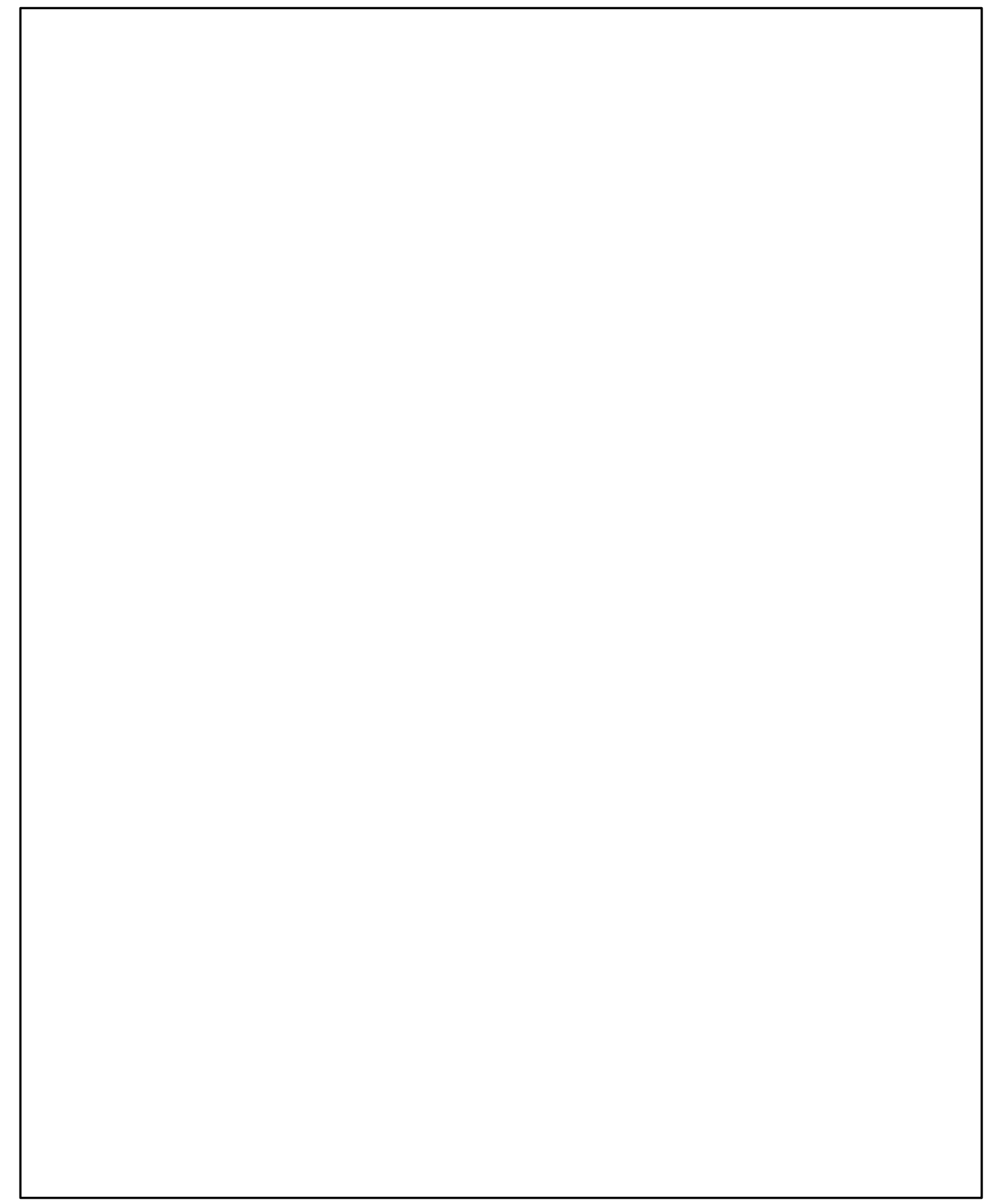

Figure 110: Nicolas Lancret, Le Départ pour Cythere, c. 1719-1720. Oil on Canvas, 73.5 x $60 \mathrm{~cm}$, Stifung Preußische Schlösser und Gärten, Berlin-Brandenburgh, Potsdam, Schloss Sanssouci. 


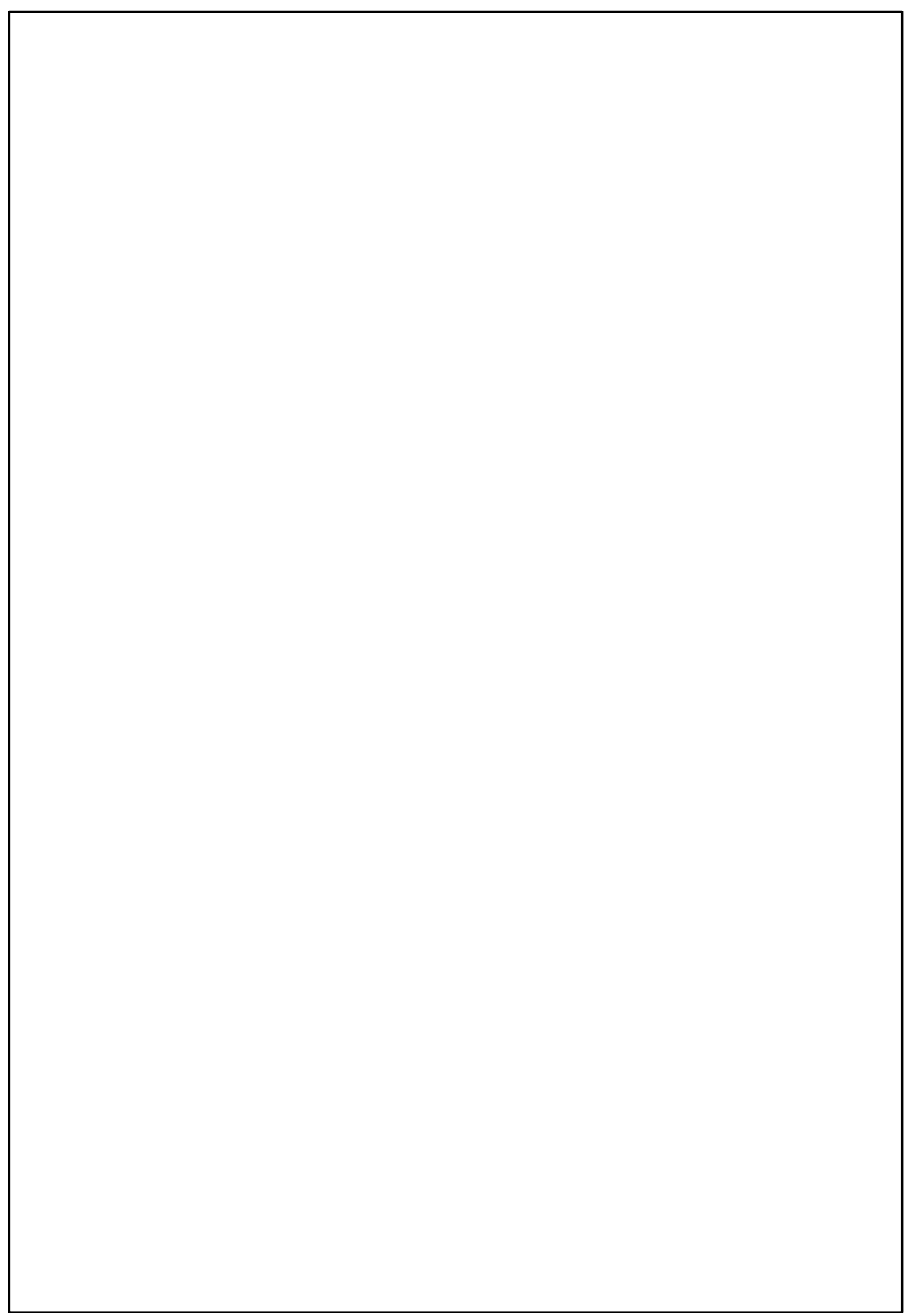

Figure 111: Nicolas Lancret, Le déjeuner de jambon, 1735. Oil on Canvas, $187.96 \mathrm{x}$ $133.05 \mathrm{~cm}$, Chantilly, Musée Condé. 


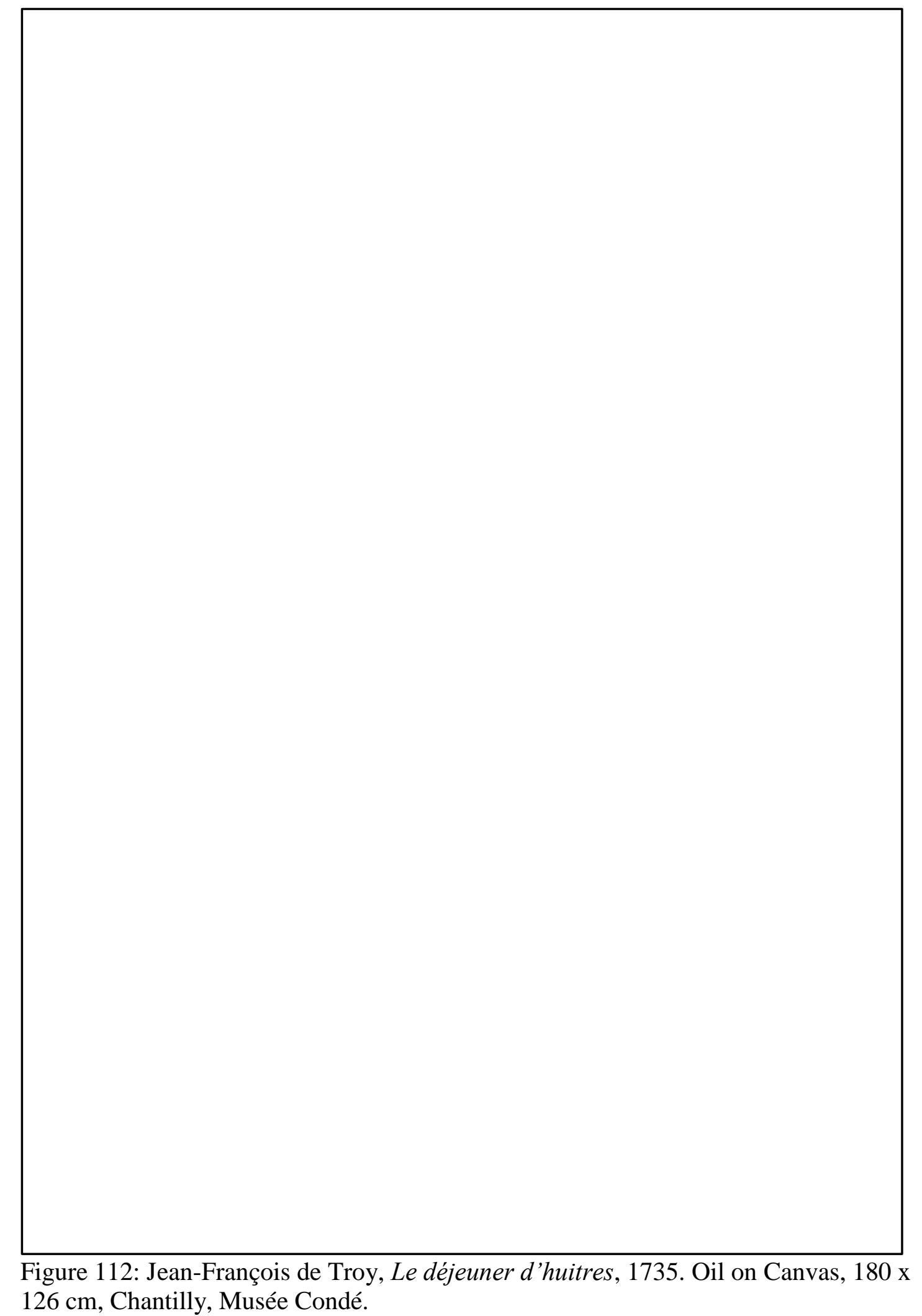

$126 \mathrm{~cm}$, Chantilly, Musée Condé. 
Figure 113: Nicolas Lancret, Le déjeuner de jambon, 1735. Oil on Canvas, 55.7 x $46 \mathrm{~cm}$, Museum of Fine Arts, Boston. 
Figure 114: Nicolas Lancret, Le déjeuner dans le foret, c. 1725 (1738). Oil on Canvas, 97 x $131 \mathrm{~cm}$, Stifung Preußische Schlösser und Gärten, Berlin-Brandenburgh, Potsdam, Schloss Sanssouci. 
Figure 115: Nicolas Lancret, Le déjeuner dans le foret, c. 1725. Oil on Canvas, 55.9 x $73.7 \mathrm{~cm}$, Detroit Institute of Arts. 


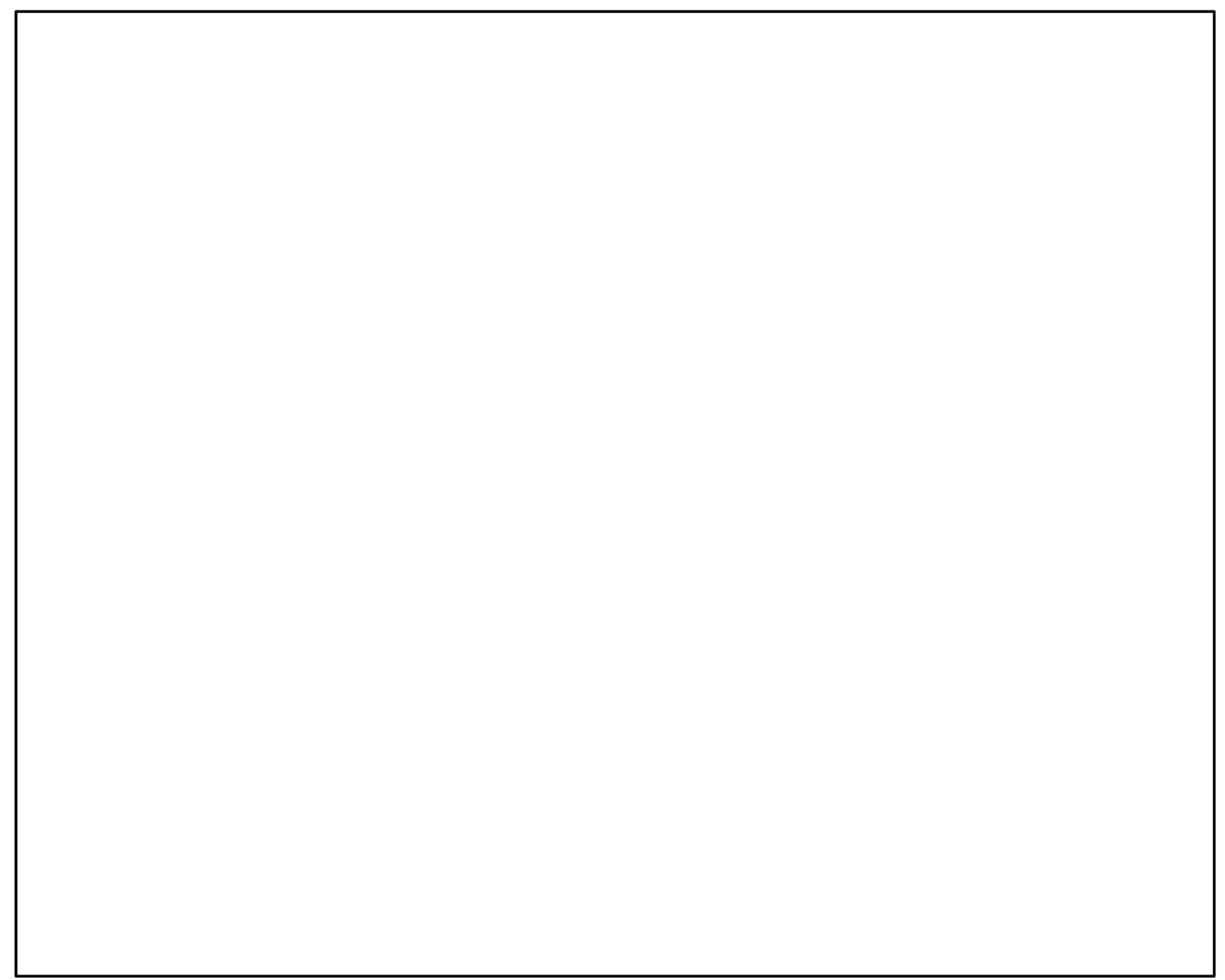

Figure 116: Nicolas Lancret, Le repas au chasse, c. 1735/1740. Oil on Canvas, $61.5 \mathrm{x}$ $74.8 \mathrm{~cm}$, National Gallery of Art, Washington D.C. 
Figure 117: Nicolas Lancret, Fête galante entre une tente et une rivière, 1740. Oil on Canvas, 60.8 x $75.2 \mathrm{~cm}$, Museum Huis Doorn, Netherlands. 


\section{Vita}

Sarah Sylvester Williams was born in Olathe, Kansas in 1983 and is a native of Kansas City, Missouri. She graduated from Cass Midway High School, Freeman, MO in 2001. She attended the University of Missouri - Kansas City where she graduated with a BA in History in 2005. She received her MA in Art History also from the University of Missouri - Kansas City in 2011. Her MA thesis, "Dining and Revelry in French Rococo Art” explores the royal commissions for Louis XV's salle à manger at Versailles and Fontainebleau. Dr. Williams received her PhD from the University of MissouriColumbia in 2018. 